\author{
Samilo Takara \\ Josemir Almeida Barros \\ Rosangela Aparecida Hilário \\ (Organizadores e Organizadora)
}

\title{
(REL)ATOS EDUCATIVOS: EXPERIÊNCIAS E PERSPECTIVAS EM PESQUISA
}
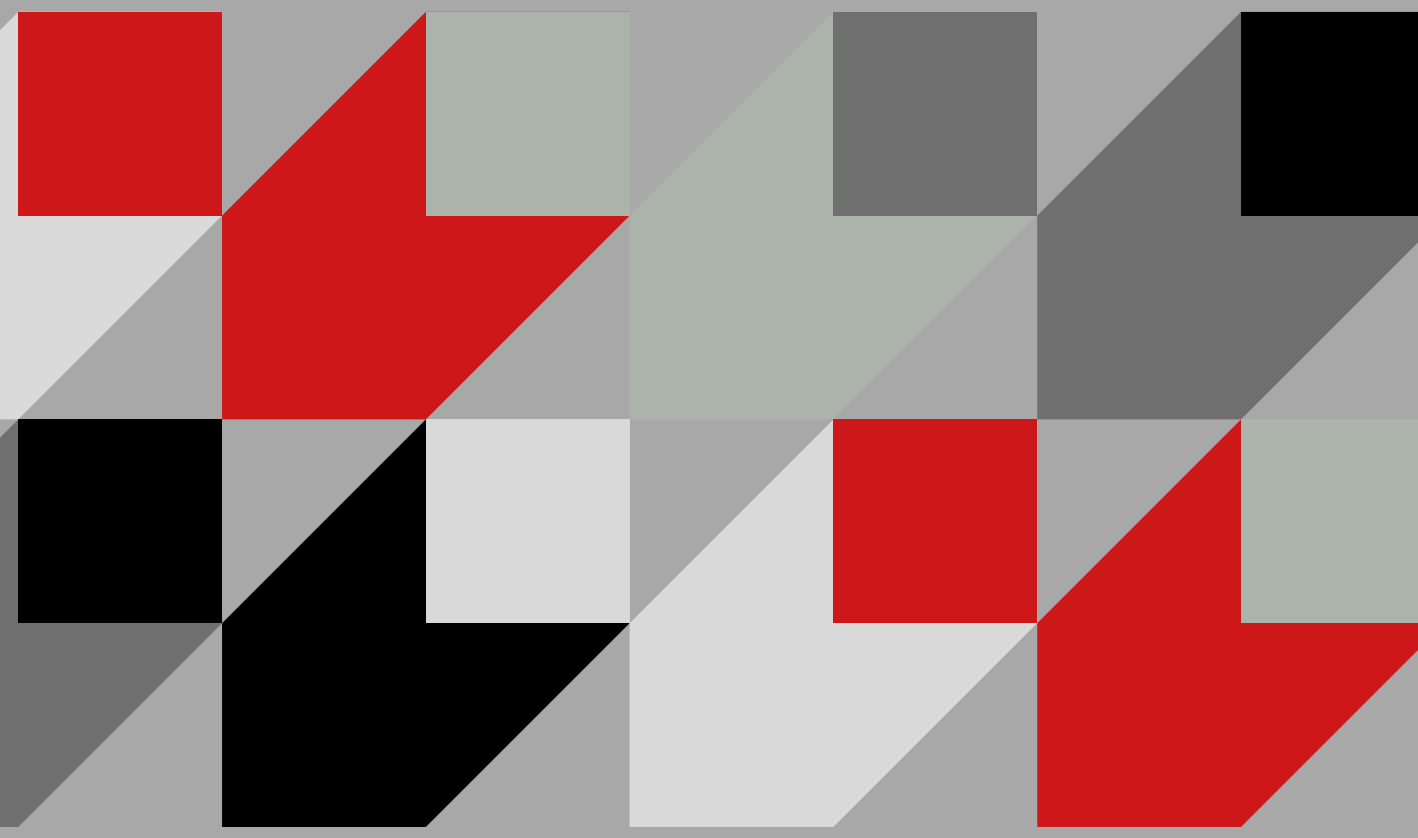

Coleção Pós-Graduação da UNIR

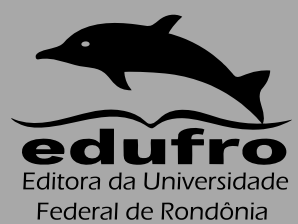




\section{(REL)ATOS EDUCATIVOS: \\ Experiências e Perspectivas em Pesquisa}

Samilo Takara

Josemir Almeida Barros

Rosangela Aparecida Hilário

(Organizadores e Organizadora) 
FUNDAÇÃO UNIVERSIDADE FEDERAL DE RONDÔNIA

Reitora Marcele Regina Nogueira Pereira

Vice-Reitor José Juliano Cedaro

EDITORA DA UNIVERSIDADE FEDERAL DE RONDÔNIA

\section{CONSELHO EDITORIAL}

Presidente Lou-Ann Kleppa

Ariana Boaventura Pereira

Carlos Alexandre Trubiliano

Eliane Gemaque Gomes Barros

Gean Carla Silva Sganderla

Leandro Soares Moreira Dill

Márcio Secco

Marli Lúcia Tonatto Zibetti

Pedro Ivo Silveira Andretta

Ricardo Gilson da Costa Silva

Xênia de Castro Barbosa

\author{
COMISSÃO CIENTÍFICA \\ Marília Lima Pimentel Cotinguiba \\ Carlos André da Silva Müller \\ Gabriel Eduardo Melim Ferreira \\ Wanderley Rodrigues Bastos \\ João Paulo Assis Gobo \\ Patrícia Goulart Tondineli \\ Lucas Martins Gama Khalil \\ Quesler Fagundes Camargo \\ Estevão Rafael Fernandes \\ Élcio Aloísio Fragoso
}

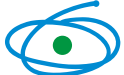

CAPES

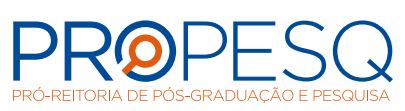

Editora Filiada

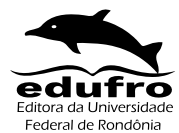

Federal de Rondônia

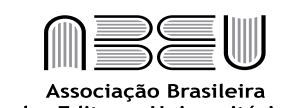

das Editoras Universitárias

Edufro - Editora da Universidade Federal de Rondônia

BR 364, Km 9,5

Campus Unir

76801-059 - Porto Velho - RO

Tel.: (69) 2182-2175

www.edufro.unir.br

edufro@unir.br 


\section{(REL)ATOS EDUCATIVOS: \\ Experiências e Perspectivas em Pesquisa}

Samilo Takara

Josemir Almeida Barros

Rosangela Aparecida Hilário

(Organizadores e Organizadora)

Coleção Pós-Graduação da UNIR

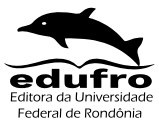

Porto Velho - RO 
(C) 2021 by Samilo Takara, Josemir Almeida Barros, Rosangela Aparecida Hilário

(Organizadores e Organizadora)

Esta obra é publicada sob a Licença Creative Commons Atribuição-Não

Comercial 4.0 Internacional.

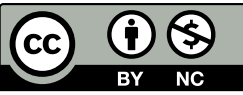

Capa:

Rosivan Diagramação \& Artes Gráficas

Revisão:

Marília Lima Pimentel Cotinguiba

Projeto gráfico:

Edufro - Editora da Universidade Federal de Rondônia

Diagramação:

Rosivan Diagramação \& Artes Gráficas

Dados Internacionais de Catalogação na Publicação

Fundação Universidade Federal de Rondônia (UNIR)

Ficha Catalográfica elaborada pela Biblioteca Central da UNIR

F981 Fundação Universidade Federal de Rondônia.

(Rel)Atos educativos: experiências e perspectivas em pesquisa / organizadores Samilo

Takara, Josemir Almeida Barros e Rosangela Aparecida Hilário. - Porto Velho, RO:

Coleção Pós-Graduação da UNIR - EDUFRO, 2021.

277 p.; il.

ISBN: 978-65-87539-51-5 (digital)

1. Educação. 2. Experiências educativas. 3. Políticas educacionais. I. Takara, Samilo. II Barros, Josemir Almeida. III. Hilário, Rosangela Aparecida. IV. Fundação Universidade Federal de Rondônia. V. Título.

CDU 37.011.3 


\section{AGRADECIMENTOS}

Esta publicação é um trabalho coletivo de pesquisadoras e pesquisadores das regiões brasileiras Norte e Centro-Oeste que atentam às demandas e/ou discussões e análises de diferentes e importantes temáticas no campo Educacional. A organização deste livro é o resultado dos esforços e investimentos intelectuais de grupos e redes de pesquisas, ensino e extensão de pessoas que dedicam ao ato de Educar e Pesquisar em importantes instituições de Ensino Superior do Brasil. Equipes que defendem a educação pública, gratuita e de qualidade.

Assim, gostaríamos de agradecer às instituições, grupos e redes de ensino, pesquisa e extensão que contribuíram com suas respectivas produções científicas, a saber, à Fundação Universidade Federal de Rondônia (UNIR); à Pró-Reitoria de Pesquisa e Pós-Graduação (PROPesq/UNIR); ao Programa de Pós-Graduação em Educação (PPGE/UNIR); ao Conselho Nacional de Desenvolvimento Científico e Tecnológico (CNPq); à Coordenação de Aperfeiçoamento de Pessoal de Nível Superior (CAPES); à Fundação de Amparo ao Desenvolvimento das Ações Científicas e Tecnológicas e à Pesquisa do Estado de Rondônia (FAPERO); à Fundação de Apoio e Desenvolvimento ao Ensino, Pesquisa e Extensão Universitária no Acre (FUNDAPE); à Fundação de Amparo à Pesquisa do Estado de Mato Grosso (FAPEMAT); aos Grupos e Redes de Pesquisa, Ensino e Extensão das Regiões Norte e Centro-oeste brasileiros; aos Programas de Pós-Graduação em Educação das Regiões Norte e Centro-Oeste brasileiros; aos Professores, Professoras, Pesquisadores, Pesquisadoras e Extensionistas das Regiões Norte e Centro-Oeste brasileiros; aos Professores e Professoras das Redes de Educação Básica das Regiões Norte e Centro-Oeste brasileiros; bem como, aos discentes dos sistemas de ensino da Educação Básica e do Ensino Superior das Regiões Norte e Centro-Oeste brasileiros. 


\section{PREFÁCIO}

Esta obra, produzida no âmbito do Programa de Pós-graduação em Educação da Fundação Universidade Federal de Rondônia (PPGE/UNIR), apresenta estudos e pesquisas - produtos de inquietações/reflexões/compromissos de grupos e redes de pesquisa, ensino e extensão vinculados a universidades públicas federais das regiões Norte (UNIR, Ufac, UFAM e Ufopa), Nordeste (UFS) e Centro-Oeste (UFTM), em torno de questões educacionais voltadas à educação básica e superior, delimitadas aos campos das políticas públicas e da formação docente.

Geralmente, o objeto de estudo de trabalhos acadêmicos como dissertações, teses ou mesmo trabalhos de conclusão de curso e de iniciação científica, por exemplo, emerge de uma observação mais atenta e comprometida da realidade que nos rodeia, um olhar "sociológico" que levanta questões "inquietantes", que nos estimulam a buscar sua compreensão e/ou aprimoramento.

Contudo, sabemos que o processo de redemocratização do estado brasileiro levou ao enfrentamento de dificuldades históricas da educação no que tange ao acesso e a permanência de crianças, adolescentes e jovens na escola, ou na universidade, com qualidade social. Se por um lado, há todo um conjunto de ações na direção da constituição de políticas públicas de educação visando melhoria da qualidade da instituição educativa, por outro lado temos ainda os baixos índices de aproveitamento, seja na educação básica, seja no ensino superior.

Esta contradição tem mobilizado pesquisadores a se debruçar sobre essas e muitas outras questões que comparecem nos capítulos desta obra, principalmente diante da pandemia da Covid 19 (e suas variantes), que assola o mundo, provocando a perda de infinitas vidas humanas e aumentando o distanciamento entre as nações e seus povos. A Educação, como não poderia deixar de ser, é impactada diretamente.

Dadas as dimensões territoriais brasileiras e o tamanho de sua população, além do descaso da classe política, podemos constatar que a Educação continua uma matéria pendente para o Brasil. Sobretudo, as grandes diferen- 
ças geográficas, socioeconômicas, políticas, culturais e inclusive ecológicas, que afetam a cada região deste país, contribuindo para manter um sistema educativo marcado por desigualdades regionais até os dias atuais, permanecendo retratadas nas muitas caras de uma realidade a ser superada: uma política educacional ainda incipiente, com um longo caminho a ser percorrido, até porque os problemas educacionais são também problemas sociais e, portanto, essencialmente problemas políticos.

Quando nos reportamos aos Estados da Amazônia legal, ainda que não sejam exclusivas, nos deparamos com dificuldades de várias ordens: além do analfabetismo, enfrentam problemas que estão diretamente relacionados ao acesso à escola, a comunicação, ao trabalho infantil, ao planejamento escolar e a fiscalização dos recursos públicos destinados à educação. Estes problemas perpassam também pela gestão educacional, o insuficiente transporte escolar, a baixa qualidade da formação dos professores e a carência de estrutura física e de material didático, assim como o desrespeito a carreira docente, dentre muitos outros.

Neste sentido, esta Coletânea intitulada "(Rel)Atos Educativos: experiências e perspectivas" busca socializar uma produção acadêmico-científica de docentes, discentes e egressos de programas de pós-graduação em educação a partir de contextos plurais, priorizando temáticas de grande relevância na atualidade, com enfoques teórico-metodológicos diversos e uma abordagem dialética de seus "achados" bibliográficos, documentais e/ou empíricos, demonstrando uma riqueza de informações que oportuniza ao leitor uma reflexão aprofundada das realidades estudadas.

Desejo a todos e todas uma ótima leitura!

Santarém/Pará, 22 de março de 2021.

Tania Brasileiro

Professora Titular

Universidade Federal do Oeste do Pará 


\section{Sumário}

11 APRESENTAÇÃO

\section{EIXO I - EXPERIÊNCIAS EDUCATIVAS EM DEBATE}

17 1ALFABETIZAÇÃO EM CLASSES MULTISSERIADAS NO CAMPO:

DIFICULDADES E IMPASSES NA PRÁTICA DOCENTE

Ely Sandra Carvalho de Oliveira

Wendell Fiori de Faria

372 A IMPORTÂNCIA DOS CONCEITOS CIENTÍFICOS NO ENSINO DE MATEMÁTICA: UMA EXPERIÊNCIA DE INTERVENÇÃO PEDAGÓGICA NA EDUCAÇÃO NÃO-FORMAL EM PORTO VELHO/RO Rafael Fonseca de Castro

Divina Rogéria Corrêa Santos

563 EDUCAÇÃO EM TEMPO INTEGRAL: ESTUDO EM ESCOLAS DA REDE ESTADUAL DE SANTARÉM-PARÁ

Maria Sousa Aguiar

Maria Lília Imbiriba Sousa Colares

764 UM ESTUDO SOBRE EVASÃO NOS CURSOS DE LICENCIATURA DO CENTRO DE EDUCAÇÃO, LETRAS E ARTES DA UFAC Mark Clark Assen de Carvalho Gerson da Silva Januário Adão Rogério Xavier Silva

\section{EIXO II - QUESTÕES EDUCACIONAIS EM PERSPECTIVA}

975 A ÉTICA DA ALTERIDADE COMO CAMINHO PARA A EDUCAÇÃO FACE À DIVERSIDADE SOCIOCULTURAL AMAZÔNICA

Wesley Cristian Mercês Teixeira

Rosângela de Fátima Cavalcante França

Eulina Maria Leite Nogueira 
1136 A EDUCAÇÃO COMO PRÁTICA DE LIBERDADE É PARA TODAS AS PESSOAS?

Rosangela Aparecida Hilário

Vinícius de Souza Santos

1327 EDUCAÇÃO RIBEIRINHA E REFLEXÃO DA PRÁTICA AMBIENTAL NO CONTEXTO AMAZÔNICO DE PORTO VELHO, RO Berenice Perpetua Simão

Clarides Henrich de Barba

Fábio Santos de Andrade

1488 SUSTENTABILIDADE NO ENSINO SUPERIOR: DISCUTINDO AS BASES DE SUA IMPLEMENTAÇÃO EM UMA UNIVERSIDADE DO INTERIOR DA AMAZÔNIA PARAENSE

Luís Alípio Gomes

Tânia Suely Azevedo Brasileiro

1619 LARGA CAMPANHA DE EDUCAÇÃO PARA AS GENTES DO CAMPO: FORMAÇÃO DE PROFESSORAS RURAIS BRASILEIRAS (1951-1963)

Nilce Vieira Campos Ferreira

17910 VÍRUS, TELAS E JANELAS: ENSINO REMOTO, MÍDIAS E ESTUDOS CULTURAIS

Fernanda Amorim Accorsi

Samilo Takara

\section{EIXO III - POLÍTICAS EDUCACIONAIS EM ANÁLISE}

19811 AÇÕES AFIRMATIVAS NA UNIVERSIDADE FEDERAL DE RONDÔNIA: EXPERIENNCIAS BEM-SUCEDIDAS DE ACESSO AO ENSINO SUPERIOR

Aparecida Luzia Alzira Zuin

Eliane Bastos

André Luiz Pestana Carneiro 
21712 EDUCAÇÃO ESCOLAR INDÍGENA: REFLEXÕES SOBRE A FORMAÇÃO DE PROFESSORES ÍNDIOS

Célio José Borges

Edilene Ferreira Gama

23513 ESTADO E POLÍTICAS PÚBLICAS EM EDUCAÇÃO: A IMPLEMENTAÇÃO DO PACTO NACIONAL PELA ALFABETIZAÇÃO NA IDADE CERTA

Juliana Cândido Matias

Josemir Almeida Barros

255140 DIREITO À EDUCAÇÃO DE QUALIDADE NAS ESCOLAS PÚBLICAS MUNICIPAIS EM HUMAITÁ

Rita Diniz Barboza

Angela Maria Gonçalves de Oliveira

269 SOBRE OS AUTORES E AS AUTORAS 


\section{APRESENTAÇÃO}

Este livro surgiu a partir de nossas inquietações a respeito das Experiências Educativas, das Questões Educacionais e das Políticas Educacionais em análise, no campo da Educação junto a ações de diversos grupos e redes de pesquisa, ensino e extensão que corroboraram para intensificar produções teórico metodológicas das Regiões Norte, Nordeste e Centro-Oeste.

Os textos são resultantes de pesquisas realizadas no campo da Educação e possuem perspectiva teórica e/ou conceitual e de campo, articulam linhas de pesquisas sobre políticas públicas e formação de professores.

A produção das Ciências em Educação mais do que sempre, nestes tempos sombrios de autoritarismo em que vivemos, precisa fortalecer a organização de pontes que juntem a escuta do movimento empírico, que guarda nos movimentos de resistência/existência para a formação/ação cidadã, e o rigor da teoria ajustada aos contextos.

Diante destas contribuições, a publicação se organiza em três eixos que compreendem as ações formativas que estão em diferentes níveis e modalidades de ensino e as discussões teóricas e analíticas que examinam as perspectivas educacionais por meio de experiências que não se realizam no contexto didático-pedagógico e metodológico.

Experiências educativas em debate é o primeiro eixo e apresenta resultados de pesquisas que analisam os contextos formativos por meio de ações educativas, práticas pedagógicas, intervenções, ações escolares e formação docente em diferentes temas que se inscrevem nas análises sobre a formação e questões que envolvem o acesso e a permanência, o ensino, a aprendizagem e a formação de professoras e professores.

As contribuições do texto Alfabetização em classes multisseriadas no Campo: dificuldades e impasses na prática docente de autoria de Ely Sandra Carvalho de Oliveira e Wendell Fiori de Faria nos provoca a compreendermos a especificidade de classes multisseriadas no campo e como estas estão distantes dos documentos oficiais que subsidiam essas práticas e como a dificuldade 
de lidar com essas especificidades fica sob a responsabilidade de docentes que não tem formação condizente para atuar neste contexto.

Na sequência, Rafael Fonseca de Castro e Divina Rogéria Corrêa Santos contribuem com a discussão sobre a importância do trabalho pedagógico com conceitos científicos por meio da perspectiva da Teoria Histórico-Cultural da Atividade. $\mathrm{O}$ texto intitulado $\mathrm{A}$ importância dos conceitos científicos no ensino de Matemática: uma experiência de intervenção pedagógica na Educação não-formal em Porto Velho/RO contribui para compreender a aprendizagem de conceitos fundamentais de conteúdos de Matemática para o desenvolvimento intelectual dos estudantes na escola ou em espaços de educação não-formal.

Maria Sousa Aguiar e Maria Lília Imbiriba Sousa Colares contribuem com o texto Educação em tempo integral: estudo em escolas da rede estadual de Santarém-Pará. As autoras analisam duas escolas estaduais de Santarém-PA, entre os anos de 2009 a 2015, na implantação do Programa Mais Educação (PME). O estudo contribui analisando que diversas habilidades, competências e conhecimentos exigidos são desafiadoras para a integração e otimização do tempo do estudante na escola.

O texto Um estudo sobre evasão nos cursos de Licenciatura do Centro de Educação, Letras e Artes da Ufac foi escrito por Mark Clark Assen de Carvalho, Gerson da Silva Januário e Adão Rogério Xavier Silva. A contribuição é resultado dos estudos com base em análise documental e nos dados obtidos em questionário respondido por coordenadores de curso. Como resultados, o texto mostra ainda existir um distanciamento entre as políticas de acesso e permanência adotadas pela Ufac, enquanto as evasões persistem.

O segundo eixo é sobre Questões educacionais em perspectiva, apresenta pesquisas que analisam as estruturas educativas, políticas, pedagógicas e éticas que embasam as práticas educativas nos contextos das instituições de ensino. Desse modo, as pesquisas problematizam questões que contribuem para o entendimento do contexto educacional em diálogo com a formação.

Wesley Cristian Mercês Teixeira, Rosângela de Fátima Cavalcante França e Eulina Maria Leite Nogueira contribuem nesta publicação com o capítulo A ética da alteridade como caminho para a educação face à di- 
versidade sociocultural Amazônica. As autoras e o autor caracterizam a diversidade amazônica em aspectos múltiplos e especificam a diversidade sociocultural. Diante desta discussão, expõem possíveis caminhos para pensar a educação neste contexto: o multiculturalismo e a ética da alteridade de Emmanuel Lévinas. A proposta empreendida no texto é um ensino pautado na filosofia levinasiana que está na relação entre os indivíduos e o ensino, nesse contexto, destinado como abertura e perplexidade como possibilidade para contemplar a diversidade amazônica na Educação.

A Educação como prática de liberdade é para todas as pessoas? é o segundo texto que compõe o segundo eixo desta obra. Rosangela Aparecida Hilário e Vinícius de Souza Santos discutem por meio de referências conceituais da interseccionalidade e da decolonialidade. O texto analisa a influência das categorias sociais raça, gênero e classe na ascensão de mulheres pretas. O texto expõe a experiência da atuação no processo de formação continuada de professoras e registra um apartheid epistemológico e social que marcam a ausência do povo preto em livros didáticos e dos desconfortos da pauta identitária no corpo docente, ainda que respaldadas pelas leis no 10.639/2003 e no 11.645/2008.

Educação ribeirinha e reflexão da prática ambiental no contexto amazônico de Porto Velho, RO de Berenice Perpetua Simão, Clarides Henrich de Barba e Fábio Santos de Andrade. O texto tem por contribuição estudar os aspectos referentes à formação por meio de uma Educação Ambiental Crítica e registra a necessidade de a escola ser reflexo do ambiente em que os alunos convivem e se relacionam com os saberes locais, o conhecimento de mundo e um espaço de acolhimento humanizado que contribua para uma formação que envolva o espaço, a corporeidade, a cultura, o trabalho, a democracia e o bem viver.

Luís Alípio Gomes e Tânia Suely Azevedo Brasileiro contribuem com o capítulo Sustentabilidade no Ensino Superior: discutindo as bases de sua implementação em uma universidade do interior da Amazônia paraense. $\mathrm{O}$ objetivo do texto é apresentar os resultados da investigação de doutorado sobre a implementação da sustentabilidade em uma universidade no interior da Amazônia. $\mathrm{O}$ autor e autora registram que a abordagem socioambiental está presente nos PPCs (Projetos Políticos Pedagógicos Curriculares) por meio de 
competências e em disciplinas em cursos de Pedagogia, Informática Educacional, Matemática-Física, Letras Português-Inglês, Biologia, História e Geografia.

O texto Larga campanha de Educação para as gentes do Campo: formação de professoras rurais brasileiras (1951-1963) de Nilce Vieira Campos Ferreira analisa a formação de professoras missioneiras pela Campanha Nacional de Educação Rural - CNER que tinha por objetivo a melhoria da educação rural. A autora analisa que essa campanha desconsiderava a história da organização do ensino, o funcionamento das escolas, os recursos destinados à instrução pública e as especificidades da comunidade na educação rural.

Vírus, telas e janelas: ensino remoto, mídias e Estudos Culturais é o capítulo produzido por Fernanda Amorim Accorsi e Samilo Takara. O texto problematiza o Ensino Remoto para as condições contemporâneas da Educação Básica e do Ensino Superior sobre as possibilidades para pensar os percalços, as dificuldades e as condições de sua efetivação. $O$ texto contribui para pensar na relação pedagógica por meio das mídias e problematizar como esses artefatos culturais contribuem para a formação das subjetividades contemporâneas.

O terceiro e último eixo é sobre Políticas Educacionais em análise e reúne pesquisas que se debruçam sobre as dimensões das políticas educacionais e as possibilidades de efetivação de ações necessárias e vinculadas aos direitos sociais nas dimensões educativas e em diferentes espaços educativos e/ou escolares. Desse modo, os estudos que contribuem com este eixo colaboram para a compreensão da relação entre as dimensões documentais e a efetivação das ações políticas propostas por administrações públicas em diferentes esferas entre outros atores sociais.

A aplicação da Lei no 12.711/2012 que é a legislação referente às cotas na Universidade Federal de Rondônia, entre os anos de 2013 e 2018, e o ingresso de cotistas nos cursos de Licenciaturas, Medicina e Direito, no Campus José Ribeiro Filho, é a análise empreendida no texto Ações Afirmativas na Universidade Federal de Rondônia: experiências bem-sucedidas de acesso ao Ensino Superior. Aparecida Luzia Alzira Zuin, Eliane Bastos e André Luiz Pestana Carneiro investigam este processo respaldados pelas perspectivas sobre a Lei de Cotas para a inclusão social e a defesa do direito à educação humanizadora, de qualidade e de respeito às cidadãs e aos cidadãos brasileiras/os. 
Célio José Borges e Edilene Ferreira Gama contribuem com o texto Educação Escolar Indígena: reflexões sobre a formação de professores índios. Neste texto, o autor e a autora discutem a formação do professor indígena no contexto das diretrizes estabelecidas em lei e por meio dos documentos e instruções publicadas pelo MEC/SECADI. O estudo apresenta como contribuição a necessidade de problematizar as questões impostas e as reflexões acerca de uma escolarização diferenciada para atender as diversidades dos povos indígenas.

Juliana Cândido Matias e Josemir Almeida Barros analisam as concepções de políticas públicas adotadas para a composição e o funcionamento do Pacto Nacional pela Alfabetização na Idade Certa - PNAIC. Por meio de um estudo bibliográfico e documental, a autora e o autor analisam legislação, dados estatísticos e escolares e a produção científica que abordam o tema. $\mathrm{O}$ texto é intitulado Estado e políticas públicas em Educação: a implementação do Pacto Nacional pela Alfabetização na Idade Certa e mostra como os interesses do governo vigente e as necessidades de mercado estão presentes nas teias estruturais das políticas econômicas, sociais e educacionais implementadas.

$\mathrm{O}$ texto $\mathbf{O}$ direito à Educação de qualidade nas escolas públicas municipais em Humaitá-AM é uma contribuição de Rita Diniz Barboza e Angela Maria Gonçalves de Oliveira. Esta contribuição é resultado de um Projeto de Iniciação Científica (PIBIC) e tem como objetivo analisar a materialidade do direito à educação quanto ao princípio constitucional de garantia de padrão de qualidade nas escolas públicas do município de Humaitá-AM. Neste estudo, pode-se compreender a materialidade do direito à educação quanto a garantia do padrão de qualidade.

Esperamos que esses resultados de pesquisas forneçam elementos para a problematização das práticas e das perspectivas educacionais e oportunizem instigantes debates sobre diferentes modos de pensar e analisar a Educação. Desejamos uma boa leitura!

Josemir Almeida Barros Rosangela Aparecida Hilário Samilo Takara 
EIXO I - EXPERIÊNCIAS
EDUCATIVAS EM DEBATE 


\section{ALFABETIZAÇÃO EM CLASSES MULTISSERIADAS NO CAMPO: DIFICULDADES E IMPASSES NA PRÁTICA DOCENTE}

Ely Sandra Carvalho de Oliveira

Wendell Fiori de Faria

\section{Introdução}

A temática que abrange este texto envolve a alfabetização e o letramento em turmas multisseriadas em escolas do campo, no munícipio de Nova Mamoré - Rondônia, envolvendo as dificuldades e os impasses inerentes a prática docente, tendo como objetivo geral analisar as dificuldades encontradas pelos docentes das escolas multisseriadas em relação ao processo de alfabetização e letramento. Constitui-se em uma pesquisa bibliográfica, e tem a seguinte questão problema: em que consiste as dificuldades da prática pedagógica encontradas pelos docentes das classes multisseriadas da educação no campo no que se refere à alfabetização e ao letramento? A temática será desenvolvida a partir dos pressupostos teóricos de Soares (2009), Tfouni (2010), Mortatti (2004, 2006), Ferreiro \& Teberosky (1999), bem como de outros autores que desempenham relevantes contribuições ao tema estudado.

Primeiro apresenta-se a contextualização do conceito de alfabetização, sua evolução, relação no processo de ensino e aprendizagem e como esse termo sofreu alterações no decorrer da história para atender às necessidades de um contexto social/educacional cambiante. Com a universalização da escola pública o processo de ler e escrever foi ampliado e segundo Mortatti (2011) o ler e o escrever passaram a ser organizados, estruturados, sistematizados e ensinados por professores nas respectivas instituições.

Na sequência, aborda-se sobre a questão dos métodos de alfabetização: método analítico (das partes para o todo) e o método sintético (do todo para as partes). Nesse momento as discussões apontam para o desafio de construir/ 
implementar métodos e concepções que deem conta do processo de ensino da leitura e escrita (alfabetizar/letrando).

Em seguida apresenta-se as considerações sobre alfabetização e letramento, o conceito do letramento e sua relação com a alfabetização nesta perspectiva.

$\mathrm{Na}$ década de 1980, as práticas de alfabetização até então utilizadas passaram a ser questionadas devido as mudanças provocadas na concepção de alfabetização mecanicista que vinha sendo empreendida na escola, esse momento deflagrou um período denominado Desmetodização do ensino em relação ao que trata do ensino da leitura e da escrita, inspirado principalmente nos resultados da pesquisa de Emília Ferreiro e Ana Teberosky (1999).

Por fim, o presente estudo apresentará sobre a problemática da alfabetização em classes multisseriadas no campo que apresentam uma realidade específica e que precisam ser levadas em consideração no aspecto que tange a questão da alfabetização e letramento. A concepção de letramento indicou a necessidade de assumir outra perspectiva educacional, concebendo o campo como um espaço diferenciado e que merece ações pedagógicas de acordo com as características que lhe são peculiares.

\section{Contextualizando o conceito da alfabetização}

Durante as últimas décadas, muitos estudiosos buscam por conceituar o que é alfabetização, tendo em vista que a definição "aprender a ler e escrever" vem sofrendo revisões significativas associadas às produções das várias áreas do conhecimento, como a Filosofia, Psicologia e a Linguística, que reconhecem o "fato de que a mera leitura e grafia das unidades menores da língua (letras, sílabas e palavras) não implicava um consequente domínio do ato de ler e escrever, como nos exigem as atividades sociais" numa sociedade democrática (Sérkez, Martins, 1996, p. 9).

De acordo com Mortartti (2004, p. 18-19):

[...] desde os primeiros censos populacionais, também se buscava conhecer o número de pessoas que sabiam (ou não) ler e escrever, resultando em dados sobre o analfabetismo da população. [...] De um modo geral, nos censos populacionais realizados até 1940, esse critério se baseava na declaração das 
pessoas a respeito de sua capacidade de ler e escrever (o próprio nome); a partir do censo de 1950, o critério passou a se basear em uma definição mais ampliada de alfabetização: pessoa capaz de ler e escrever um bilhete simples no idioma que conhecesse; aquela que soubesse apenas assinar seu nome não era, portanto, considerada alfabetizada.

Assim, por muitos anos a alfabetização foi considerava como o processo de "codificação" e "decodificação", considerando uma pessoa alfabetizada quando era capaz de "desenhar o nome", uma ação apenas de memorização e reprodução das letras e sons.

[...] O aprendizado do código alfabético se dava por meio do ensino transmissivo das unidades da língua, seguindo uma progressão pré-determinada que ia das unidades mais fáceis para as mais difíceis. Partia-se do pressuposto de que todos os alunos iniciavam o processo sem conhecimento algum sobre a escrita e que cabia aos professores o ensino das letras, sílabas e palavras. Ao aluno, nessa concepção, cabia um papel passivo de "recebedor" de algo pronto: a língua (Brasil, 2012, p. 7).

O ensino da leitura e escrita acontecia de forma tradicional, o que deixava o aluno sobrecarregado, onde o conhecimento acontecia sem exigir nenhum significado para o aluno e a língua escrita era considerada apenas como codificação da linguagem.

Esse conceito de alfabetização foi criticado por especialistas que defendiam que esse processo ia além da memorização de palavras sem nenhum significado para as crianças.

A esse respeito podemos confirmar em Teale (1982, p. 559 apud Tfouni, 2010, p. 17) que:

William Teale parece separar os dois processos (alfabetização e escolarização) quando afirma que '[...] a prática da alfabetização não é meramente a habilidade abstrata para produzir, decodificar e compreender a escrita; pelo contrário, quando as crianças são alfabetizadas, elas usam a leitura e a escrita para a execução das práticas que constituem sua cultura'. 
Segundo Tfouni (2010), a alfabetização não se configura em uma habilidade meramente abstrata, desprovida de sentido para os alunos, pois ao ler e escrever eles expressam elementos de sua cultura e ao mesmo tempo farão uso desses conhecimentos em suas práticas sociais. Nesse sentido, não basta apenas ensinar a ler e escrever os códigos de forma aleatória e desprovida de sentido.

Nessa mesma perspectiva, Soares (2009, p. 16) diz que:

[...] alfabetizar é proporcionar condições para que o indivíduo [...] tenha acesso ao mundo da escrita, tornando-se capaz não de ler e escrever, enquanto habilidades de decodificação do sistema da escrita, mas, e, sobretudo, de fazer uso real e adequado da escrita com todas as funções que ela tem em nossa sociedade e também como instrumento de luta pela conquista da cidadania plena.

Como podemos verificar, a autora também discorda do conceito tradicional de alfabetização, desprovido de sentido para o aluno. Para ela, estar alfabetizado é sinônimo de exercício de cidadania, em que o sujeito possa fazer uso em suas atividades sociais, sendo capaz de ler o mundo.

Somente a partir do Século XIX, momento em que se consolida gradativamente um sistema público de educação, começa a preocupação com a concepção pedagógica que fundamenta as práticas docentes de alfabetização e o desenvolvimento de métodos para o ensino da leitura e da escrita.

Nesse momento, subsidiada pelas mudanças sociais, políticas e econômicas a escola passou a se preocupar em implantar novas estratégias para ensinar todos ao mesmo tempo e no mesmo espaço, surgindo assim os métodos de alfabetização que serão apresentados a seguir.

\section{Métodos de alfabetização: história e características}

A alfabetização brasileira torna-se mais evidente a partir da história dos métodos de alfabetização, especialmente no final do século XIX, quando saber ler e escrever passou a ser considerado como instrumento de desenvolvimento do Estado-Nação e posteriormente requisito para participar do processo democrático nacional. Até então, ler e escrever era privilégio para poucos, que 
aprendiam de forma assistemática em seus lares, ou nas escolas do Império, nas aulas régias, numa educação extremamente elitista e excludente.

De acordo com Mortatti (2004), com a universalização da escola obrigatória, laica e gratuita para todos, a leitura e escrita passam a ser objetos de ensino e aprendizagem sistematizado. Dessa forma houve a necessidade de uma organização do ensino e de profissionais qualificados para atuar no ensino das primeiras letras.

Nesse cenário, surgiu então as discussões sobre as metodologias do ensino da leitura e da escrita, iniciando as reflexões sobre qual método de alfabetização seria mais eficiente, o que Mortatti (2009) denominou "de querela dos métodos”.

Segundo a autora:

[...] os métodos de alfabetização, como se sabe, podem ser classificados em dois tipos básicos: sintético (da 'parte' para o 'todo') e analítico (do 'todo' para a 'parte'). Dependendo do que foi considerada a unidade lingǘstica a partir da qual se devia iniciar o ensino da leitura e escrita e do que se considerou 'todo' ou 'parte', ao longo da história da alfabetização no Brasil, foi-se sedimentando a seguinte subdivisão classificatória desses métodos: métodos sintéticos (de marcha sintética): alfabético, fônico, silábico; e métodos analíticos (de marcha analítica): palavração, sentenciação, historieta, conto (Mortatti, 2009, p. 94).

A partir da classificação dos métodos em sintético e analítico apresentados pela autora passaremos a discorrer sobre as principais características desses métodos de alfabetização.

Os métodos sintéticos, considerados os mais antigos, caracterizam-se por priorizar as unidades menores da língua, ou seja, vai da parte para o todo, como as letras, as sílabas, para se chegar as unidades maiores que são as palavras, as frases ou o texto.

Nesse grupo, estão inseridos os seguintes métodos: o alfabético ou de soletração, o fônico e o silábico ou de silabação. 
a) O método alfabético ou de soletração: caracteriza-se pela memorização e pela aprendizagem das letras, depois forma as sílabas fazendo a junção das vogais com as consoantes para em seguida formar as palavras que integram o texto. De acordo com Carvalho (2010), o nome das letras é associado à forma visual, as sílabas são aprendidas de cor e com elas se formam palavras isoladas.

b) O método fônico, também conhecido como fonético: nesse método a atenção é voltada para a dimensão sonora da língua, o processo de ensino inicia-se com a forma e o som das vogais, em seguida das consoantes, para posteriormente cada letra aprendida como um fonema ir sendo unido a outro, formando as sílabas e as palavras. Parte-se de uma sequência gradativa, iniciando dos sons mais fáceis para os mais complexos. O ensino da leitura está baseado na decodificação, e a escrita, na codificação.

c) o método silábico ou de silabação: nesse método, a principal unidade de análise é a sílaba. Sua ênfase também está voltada aos mecanismos de codificação e decodificação e a memorização é utilizada como recurso didático, o que não leva em consideração a capacidade de compreensão do aluno.

Independentemente do método acima escolhido pelo professor para alfabetizar, todos desconsideram o uso social da língua, ensinando o aluno a decodificar letras e sílabas de forma mecânica e desconsideram o papel que ela exerce na compreensão e interpretação dos textos no cenário crítico e reflexivo.

Os métodos analíticos têm como ponto de partida as unidades linguísticas maiores, como palavras, frases ou textos. Segundo Ferreiro; Teberosky (1999), o método analítico de aprendizagem na alfabetização como também é conhecido, trata desse processo como algo muito maior que a decodificação de letras e sílabas, ele trata do reconhecimento das palavras e orações como um todo, para depois tratar dos componentes menores que constituem as palavras.

Nesse grupo estão os métodos de palavração, de sentenciação e global de contos.

a) O método da palavração: é aquele que parte da palavra, a criança é colocada diante de uma lista de palavras ditas e compreendidas num processo oral, usando, assim, a técnica da memorização, para o reconhecimento global de certa quantidade de palavras da lista em combinações diferentes, para cons- 
truírem sentenças significativas e, na sequência, trabalhar as sílabas e letras até a criança se tornar capaz de fazer, de forma automática, as conversões letras/ sons (Morais; Albuquerque; Leal, 2005).

b) O método de sentenciação: a unidade de análise é a sentença, que após ser compreendida e reconhecida globalmente, passa pela decomposição em palavras, e finalmente em sílabas.

c) O método global de contos: nesse processo o ensino parte de pequenas histórias ou pequenos trechos, que em seguidas são decompostos em frases, as frases em palavras e as palavras em sílabas, para que posteriormente o aluno possa formar novas palavras com as sílabas estudadas.

Esses métodos foram considerados tradicionais pois desconsideravam a criatividade do aluno e eram baseados apenas em cópias, ditados e exercícios mecânicos, assumindo a memorização como conceito de aprendizagem. Não era dada oportunidade aos alunos na participação ativa das atividades como sujeito aprendiz e o texto não tinha uma proximidade com a realidade do aluno.

Não havia a preocupação de formar leitores críticos e reflexivos, uma vez que as atividades eram totalmente descontextualizadas da realidade do aluno, e não priorizavam atividades que contemplassem situações em que os alunos fizessem uso da leitura e escrita em diferentes situações do contexto social.

Superando as bases destes métodos apresentados, o letramento baseado nas pesquisas de Ferreiro e Teberosky (1999) e Soares (2009) surge como a possiblidade de considerar o aluno como sujeito no processo de construção dos conhecimentos e da alfabetização, como discorremos na sequência.

\section{Alfabetização, letramento e suas relações}

$\mathrm{Na}$ década de 1980, as práticas de alfabetização até então utilizadas passaram a ser questionadas devido ao fracasso da escola no que se referia à alfabetização, período como já mencionamos, denominado Desmetodização do ensino. Dessa forma, segundo Mortatti (2006, p. 10):

[...] introduziu-se no Brasil o pensamento construtivista sobre alfabetização, resultante das pesquisas sobre a psicogênese da língua escrita desenvolvidas pela pesquisadora argentina Emília Ferreiro e colaboradores. 
Deslocando o eixo das discussões dos métodos de ensino para o processo de aprendizagem da criança (sujeito cognoscente), o construtivismo se apresenta não como um método novo, mas como uma 'revolução conceitual', demandando, dentre outros aspectos, abandonarem-se as teorias e práticas tradicionais, desmetodizar-se o processo de alfabetização e se questionar a necessidade das cartilhas.

Ferreiro e Teberosky (1999), desenvolveram suas pesquisas com base no entendimento de que a língua escrita deve ser entendida como um sistema de representação da linguagem. Em seus estudos sobre a psicogênese da língua escrita elas afirmam que as crianças ao aprender a ler e escrever passam por fases, construindo diferentes níveis/hipóteses. Tais hipóteses baseadas nos conhecimentos prévios dependem das interações com seus pares e com os materiais escritos que circulam socialmente. Suas pesquisas modificaram o eixo das discussões, que foi deslocado dos métodos de ensino para a reflexão acerca da aprendizagem da criança.

Podemos constatar nas palavras das autoras Ferreiro e Teberosky (1999, p. 24) que:

Nossa atual visão do processo é radicalmente diferente: no lugar de uma criança que espera passivamente o reforço externo de uma resposta produzida pouco menos que ao acaso, aparece uma criança que procura ativamente compreender a natureza da linguagem que se fala à sua volta, e que, tratando de compreendê-la, formula hipóteses, busca regularidades, coloca à prova suas antecipações e cria sua própria gramática (que não é simples cópia deformada do modelo adulto, mas sim criação original).

Com base no que evidenciam as autoras sobre a alfabetização, passou-se a compreender como o aluno constrói seu entendimento sobre a escrita como elemento fundamental para que o processo de alfabetização apresente resultados satisfatórios. Essa é uma concepção construtivista de alfabetização que prima pela valorização do conhecimento que o aluno traz ao entrar na escola - conhecimentos prévios. Os resultados da pesquisa e o novo método fundamentaram a discussão sobre o novo conceito de alfabetização na educação: o letramento. 
Soares (2009) aborda o letramento numa perspectiva sócio histórica ao defender que o sujeito deve se apropriar da leitura e da escrita para que faça uso nas suas práticas sociais. A autora defende que embora o processo de alfabetização envolva duas aprendizagens distintas (ler e escrever) ambos devem andar juntos, o que ela denomina de alfabetizar letrando. Para a autora, enquanto alfabetizar significa se apropriar do sistema de escrita alfabética, ou seja, se apropriar da aprendizagem da leitura e da escrita, o letramento estaria ligado a apropriação dessas capacidades e habilidade para que o sujeito fizesse o seu uso em diferentes contextos sociais.

Tfouni (2010, p. 24), enfatiza que a alfabetização está no plano individual e refere-se a aprendizagem das habilidades necessárias para a aprendizagem da leitura e da escrita, já o letramento "[...] focaliza os aspectos sócio históricos da aquisição da escrita”. Para ela, não existe “[...] letramento grau zero o que do ponto de vista sócio histórico existe nas sociedades modernas são graus de letramento". Como podemos confirmar, sua teoria está baseada nas ideias de Vygotsky, pois para ela a relação do sujeito com a sociedade em que vive também possibilita a aprendizagem através de suas experiências.

Mortatti (2004), assim como Soares (2009) e Tfouni (2010), também defende que saber ler, escrever e utilizar a leitura nas práticas sociais são necessidades inquestionáveis para o exercício da cidadania na sociedade atual.

O termo letramento ainda é considerado muito atual na educação brasileira, mesmo que, segundo Soares (2005), tenha sido utilizado pela primeira vez na década de 1980, conforme podemos constatar:

O letramento (palavra que apareceu pela primeira vez por Mary Kato, 1986) resulta da ação de ensinar e aprender as práticas sociais de leitura e escrita; é o estado ou condição que adquire um grupo social, ou indivíduo, como consequência de ter-se apropriado da escrita e de suas práticas sociais (Soares, 2005, p. 33).

O surgimento do termo letramento emergiu da necessidade de se explicar o que havia além da alfabetização, levando em consideração o seu papel social. Por isso, houve uma preocupação dos linguistas e vários estudos foram realizados acerca da escrita e da alfabetização. 


\section{A alfabetização em classes multisseriadas no campo}

A legislação brasileira contemplou a educação rural a partir da promulgação da Constituição de 1988, prescrevendo em seu artigo 205 que "a educação, direito de todos e dever do Estado e da família, será promovida e incentivada com a colaboração da sociedade, visando ao pleno desenvolvimento da pessoa, seu preparo para o exercício da cidadania e sua qualificação para o trabalho" (Brasil, 1988). Colocando assim, o Estado na obrigação de promover meios para ofertar a educação a todos, independentemente de cor, raça ou localização em que vive.

Em seguida a aprovação da Lei de Diretrizes e Bases da Educação Nacional 9394/96, em seu artigo 28, contribuiu para que a população do campo começasse uma luta pelo que lhe era de direito, iniciando movimentos de reivindicações da educação no e do campo. Mesmo com a legislação contemplando esse direito, pode-se assinalar uma descontinuidade no sentido de poucas escolas e do acesso não atingir boa parte dessa clientela. Essa problemática acarretou movimentos que reivindicaram uma educação pública que atendesse essas camadas populares do campo, fossem elas agricultores, indígenas, quilombolas, entre outros.

Apesar de uma política de nucleação escolar ${ }^{1}$ e o fechamento de unidades escolares na zona rural de todo o país, a maiorias das escolas do campo se organizam no sistema multisseriado, onde as crianças de séries e idades diferentes são agrupadas na mesma sala.

Ao definir as classes multisseriadas Rosa (2008, p. 228) afirma que,

[...] a classe multisseriada é organizada, na maioria das vezes, pelo número reduzido de alunos para cada série, o que a caracteriza como mais do que uma simples classe. Ela representa um tipo de escola que é oferecida a determinada população e remete diretamente a uma reflexão sobre a concepção de educação com que se pretende trabalhar.

1 De 2002 a 2009, mais de 20 mil escolas foram fechadas nas áreas rurais de todo o país (dados do Censo INEP/MEC 2009). Apenas de 2009 a 2012, mais de 4 mil escolas rurais foram fechadas (INEP/MEC 2013). A política de nucleação escolar consiste no fechamento de escolas nas pequenas localidades rurais e na transferência dos estudantes para escolas das sedes dos municípios (na área urbana) ou escolas de outras localidades rurais. As crianças são transportadas por longas distâncias e em estradas precárias, sob o questionável argumento de melhoria da "qualidade" ou "eficiência" do ensino. 
Nesse contexto, os professores deveriam aproximar as suas práticas pedagógicas alfabetizadoras às experiências que os alunos já vivenciam em seu cotidiano, para que seja oportunizado a estes ler e escrever com propriedade fazendo uso desses conhecimentos com autonomia em suas relações sociais.

Ao refletirmos sobre alfabetização e letramento em escolas do campo, devemos pensar na realidade à qual a escola está inserida, questões sociais, econômicas e ambientais as quais a escola se insere e como criar situações significativas do uso real da leitura e da escrita?

Sem dúvidas, os desafios das escolas rurais são particulares, partindo desde questões estruturais, falta de profissionais de apoio ao docente, tendo este que exercer várias funções pedagógicas, administrativas e organizacionais. Mas como pensar em uma proposta de alfabetização e letramento que atenda essa clientela?

Conforme o Caderno da Educação do Campo, Unidade 1 - Currículo no Ciclo de alfabetização: Perspectivas, para uma Educação do Campo (2012), torna-se obrigatória a tarefa de inserir, no debate sobre alfabetização, as especificidades da realidade do campo, considerando-se a diversidade de experiências e modos de organização curriculares, assim como a história de constituição dos povos do campo e das infâncias ali presentes.

Vale ressaltar que a proposta do referido caderno vem ao encontro do que é preconizado no artigo 28 da LDB no 9.394/96, conforme podemos visualizar abaixo:

[...] conteúdos curriculares e metodologias apropriadas às reais necessidades e interesses dos alunos da zona rural; organização escolar própria, incluindo a adequação do calendário escolar às fases do ciclo agrícola e às condições climáticas e adequação à natureza do trabalho na zona rural (Brasil, 1996).

Nesse sentido, faz-se necessário o reconhecimento e valorização da diversidade dos povos do campo, a formação docente deve ser diferenciada, como já preconiza a legislação. Assim como a possibilidade de organização diversa das escolas, conteúdos que levem em consideração as peculiaridades locais e práticas pedagógicas significativas e contextualizadas. 
O processo de alfabetização deve proporcionar aos alunos uma compreensão de sua realidade através da leitura e da escrita, possibilitando dessa forma que o estudante consiga resolver os seus problemas do cotidiano. No entanto, sabemos que na maioria das vezes isso não ocorre por diversos fatores, como falta de estrutura adequada, salas multisseriadas, ausência de formação docente em metodologias voltadas para a educação no campo etc.

Trabalhar em turmas multisseriadas consiste em um enorme desafio e, desta forma, esses profissionais da educação sentem o peso de carregar a responsabilidade de exercer suas práticas docentes em salas de aula com alunos de faixa etária e séries diferentes.

Conforme destaca Molinari (2009), em entrevista para a Revista Nova Escola:

Apesar de a diversidade estar presente em qualquer grupo, na escola rural ela chama muito mais a atenção por concentrar no mesmo espaço - e ao mesmo tempo - crianças de idades muito díspares, da Educação Infantil aos últimos anos do Ensino Fundamental. E, geralmente, o professor não tem um auxiliar trabalhando com ele. A responsabilização da multisseriação pelo fracasso escolar nessas turmas sempre aparece no discurso dos professores. Eles veem nisso um problema que prejudica principalmente o ensino dos menores - os que demandam mais atenção -, mas que também dificulta o dos maiores, que acabam não tendo tarefas ou atividades específicas que os ajudem a progredir. (Nova Escola, 2009, p. 01).

Embora saibamos que a diversidade está presente em qualquer turma, sem dúvidas, em uma turma multisseriada ela chama muito mais atenção, pois o professor terá que ter habilidade para atender os alunos desde a Educação Infantil aos Anos Iniciais do Ensino Fundamental, o professor dessas turmas geralmente não tem um auxiliar, as escolas não apresentam uma equipe pedagógica para assessorá-1o. Os professores consideram este como um dos fatores que prejudicam o aprendizado do aluno, tendo em vista que os menores ficam sem a devida atenção, enquanto o planejamento de atividades adequadas para os maiores também é precário. 
Coadunando com esse pensamento, Leal (2005, p. 91 apud Sá; Pessoa, 2015 , p. 04) enfatiza que uma das habilidades mais difíceis e relevantes que precisam ser desenvolvidas pelos professores é a de "identificar as necessidades de cada aluno e atuar com todos ao mesmo tempo".

Essa é uma das prerrogativas que dificulta desenvolver a alfabetização em consonância ao que preconiza o letramento, pois o professor tem dificuldades múltiplas para realizar o levantamento dos conhecimentos prévios dos alunos e para empreender metodologias e atividades que contribuam para que o aluno possa superar suas dificuldades e construir outros conhecimentos para prosseguir no processo de alfabetização.

Ferri (1994, p. 67), após a realização de pesquisa também apresenta algumas limitações que os professores das classes multisseriadas afirmam ter em suas práticas pedagógicas:

a) o professor sente solidão e está, de fato, isolado;

b) há dificuldade de atendimento individual aos alunos;

c) as crianças têm dificuldade em se adaptarem à $5^{a}$ série;

d) o professor acumula cargos: é também merendeiro, faxineiro, diretor, secretário;

e) existem dificuldades de acesso ao material didático e às bibliotecas;

f) atender quatro séries ao mesmo tempo é muito trabalhoso;

g) as crianças de $1^{\mathrm{a}}$ série, no processo de alfabetização, são muito prejudicadas, pois não têm a atenção de que necessitam;

h) planejar para quatro séries, fazer quatro planos por dia é demais;

i) a aprendizagem das crianças parece mais lenta, porque é muito dificultada pelo contexto em que elas vivem. Elas quase não têm acesso a livros, quase nunca saem da comunidade;

j) o professor, que não mora na comunidade, não tem tempo de conhecer melhor a comunidade e seus alunos. Se depender de ônibus, quase não tem tempo nem para dar o período de aula, pois precisa utilizar-se do único transporte da região que sai no mesmo horário de aula; 1) são crianças muito diferentes entre si. Há crianças de 7, de 13, de 14 anos. Os grupos são muito heterogêneos. 
Assim, alfabetizar exige do professor atenção adequada às necessidades de cada aluno para que possa planejar as atividades que promovam o avanço de cada um, sem dúvidas, em uma turma multisseriada onde ele terá que lidar com as diferentes séries, dentre todas as atribuições, será necessário dispor de mais tempo para planejar atividades para a melhor organização do tempo didático e para preparar atividades formativas.

Como podemos constatar, Molinari (2009) reforça que essa é uma dificuldade encontrada pelos docentes:

O maior problema é organizar o tempo didático. Quando se deparam com crianças de várias séries ou ciclos, com diferentes necessidades de aprendizagem, dividindo o mesmo espaço e a atenção deles, os docentes pensam que a solução é fazer planejamentos distintos para cada grupo. Porém essa nunca foi uma estratégia eficiente, pois o professor, durante a aula, precisa correr de um lado para o outro tentando atender a todos e, obviamente, ele não dá conta de acompanhar o desenvolvimento dos trabalhos. Se tiver de optar por dar mais atenção a um determinado grupo, certamente se dedicará aos que estão em fase de alfabetização, deixando os outros com atividades fáceis de executar para o nível deles - não demandando a intervenção docente, o que não lhes propicia a construção de conhecimento (Nova Escola, 2009, p. 1).

Segundo a autora, planejar atividades distintas para cada grupo que também apresentam dificuldades de aprendizagem distintas não será uma estratégia eficiente, tendo em vista que o docente tenderá a dar mais atenção a um determinado grupo, certamente aos que estão em fase de alfabetização e deixará de fazer intervenções adequadas para os outros grupos avançarem.

O que muitos estudiosos e pesquisadores defendem é que se planeje uma rotina didática que contemple atividades diversificadas conforme Leal (2005 apud Sá; Pessoa, 2015, p. 5):

[...] propõe que o ensino seja planejado levando-se em conta a construção de uma rotina que abarque um conjunto de atividades permanentes, atividades esporádicas, trabalho com jogos, projetos e sequências didáticas, 
envolvendo ludicamente as crianças em sua realidade, ao mesmo tempo em que favoreça o planejamento e acompanhamento sistemático do ensino e das aprendizagens.

Nessa perspectiva, podemos entender que a rotina pedagógica, a diversificação de atividades e as formas de agrupamento produtivos das crianças em turmas multisseriadas são estratégias que podem ser relevantes para que a heterogeneidade de aprendizagens possa favorecer o avanço dos conhecimentos dos alunos em leitura e escrita.

Outra questão a ser considerada nas classes multisseriadas no campo é a formação docente adequada para a atuar de acordo com a realidade. Torna-se fundamental pensar sobre o papel do professor responsável por desenvolver o processo formativo e aprender a lidar com essa diversidade.

Conforme os artigos 12 e 13 das Resolução CNE/CEB 1, de 3 de abril de 2002, que instituiu as Diretrizes Operacionais para Educação Básica do Campo, foi orientado que os cursos de formação inicial e continuada para o exercício da docência no campo devem contemplar conhecimento sobre os conteúdos específicos da realidade no campo, a fim de que estes possam atuar de modo competente nesses espaços.

Historicamente, a formação docente para o campo sempre foi baseada nos parâmetros urbanos, em que os currículos são baseados na realidade e experiências urbanas, conforme evidencia o documento do Ministério da Educação "Panorama da Educação no Campo":

[...] as condições de trabalho dos profissionais do magistério permanecem precárias. No caso específico da área rural, além da baixa qualificação e dos salários inferiores aos da zona urbana, eles enfrentam, entre outros problemas, sobrecarga de trabalho, alta rotatividade e dificuldade de acesso à escola, em função das condições das estradas e da falta de ajuda de custo para a locomoção (Brasil, 2007, p. 33).

Todos esses fatores elencados pelo Ministério da Educação e que também são constatados na pesquisa de Ferri (1994), refletem diretamente nos resultados e certamente são entraves para a vivência de práticas pedagógicas voltadas para a realidade e a diversidade do Campo. 
Assim, diante dessa realidade e desafios apresentados, a alfabetização e letramento nas classes multisseriadas no campo deve ser pensada através de políticas públicas que primem pela valorização e fortalecimento dos saberes, que levem em consideração a apropriação da leitura e escrita de maneira que o sujeito do campo seja inserido em práticas sociais significativas e vinculadas aos saberes do campo.

Dessa forma:

Para que o processo de alfabetização das crianças contribua com o fortalecimento das identidades coletivas e diversos saberes dos povos do campo é preciso que o mesmo se dê de forma estreitamente articulada às comunidades ali existentes, ampliando e valorizando os conhecimentos e vínculos das crianças com a realidade em que vivem. Neste sentido é que não podemos dissociar o desenvolvimento dos processos cognitivos dos formativos, ou a alfabetização das práticas sociais e culturais de escrita e leitura, o ensino das disciplinas escolares com os contextos econômicos, políticos e ambientais em que as crianças do campo estão inseridas (Brasil, 2012, p. 9).

Alfabetizar e letrar, como vimos, são processos distintos, porém indissociáveis que devem estar presentas na prática docente do campo. É imperativo que urgentemente essas práticas de alfabetização e letramento sejam repensadas para que os alunos tenham garantidos os seus direitos, no sentido de que, além de uma alfabetização que promova a associação da leitura e escrita às suas práticas sociais, também sejam oportunizados estudos dos conteúdos das várias áreas do conhecimento associados à realidade dos alunos do campo.

\section{Considerações finais}

Com a realização da pesquisa pode-se constatar que a alfabetização durante muito tempo era concebida meramente como uma codificação e decodificação dos símbolos escritos. O ensino da leitura e escrita era baseado na memorização dos sons e das letras, desprovido de significado para o aluno.

Bastava saber escrever (desenhar) o nome para que o sujeito fosse considerado alfabetizado, mas esse conceito foi criticado por especialistas que 
consideravam que esse processo ia além da memorização. Os critérios gradativamente foram atualizados e esse conceito foi se ampliando de acordo com as exigências da sociedade que passou a requerer um novo perfil para o cidadão.

Com o passar dos anos, sobretudo no século XIX, com a criação de um sistema público de educação, começaram os debates acerca das concepções que fundamentavam as práticas do ensino da leitura e da escrita - alfabetização. Nesse momento, a escola passou a se preocupar em como criar estratégias para ensinar todos ao mesmo tempo e no mesmo espaço, surgindo assim os métodos de alfabetização: os métodos analíticos e sintéticos.

Esses métodos de ensino foram considerados tradicionais, tendo em vista que não levavam em consideração a criatividade e necessidades dos alunos, as atividades eram baseadas apenas em cópias, ditados e exercícios mecânicos, considerando a aprendizagem como a memorização. Não era dada oportunidade aos alunos na participação ativa nas atividades como sujeito aprendiz. As atividades eram totalmente descontextualizadas da realidade do aluno, e não priorizavam atividades que contemplassem situações em que os alunos fizessem uso da leitura e escrita em diferentes situações do contexto social.

A partir da década de 1980, surge, com os estudos de Ferreiro e Teberosky (1999), a preocupação de como os alunos aprendem a ler e escrever. As pesquisadoras afirmam que as crianças ao aprender a ler e escrever passam por fases, construindo diferentes níveis/hipóteses. Tais hipóteses baseadas nos conhecimentos prévios dependem das interações com seus pares e com os materiais escritos que circulam socialmente.

Soares (2009) trouxe em seus estudos na perspectiva do letramento, afirmando que o ensino da leitura e da escrita deve servir ao sujeito para que faça uso em situações reais de sua vida. Segundo ela, embora o processo de alfabetização envolva duas aprendizagens distintas (ler e escrever) ambos devem andar juntos, o que ela denomina de alfabetizar letrando. O letramento estaria ligado a apropriação dessas capacidades e habilidade para que o sujeito faça uso em diferentes contextos sociais.

Por fim, no que se refere a problemática da alfabetização em classes multisseriadas no campo, a pesquisa mostra que são muitos os desafios apre- 
sentados ao professor nesse contexto. Segundo os autores pesquisados, podemos destacar: a dificuldade de lidar com a diversidade, que embora exista em qualquer sala de aula, em uma classe multisseriada o professor terá que atender desde a educação infantil às séries iniciais do ensino fundamental, a organização do tempo pedagógico é outro ponto a ser superado pelo professor. A rotina pedagógica deverá ser organizada de maneira que contemple várias atividades que possibilitem o avanço dos alunos. Uma estratégia para que se trabalhe com essas atividades poderá ser os agrupamentos produtivos.

Uma outra questão a se considerar é a formação docente voltada para a realidade do campo, embora tenha uma legislação que a contempla, exigindo formação específica para atuar em escolas do campo, ainda é preciso que a lei se efetive em políticas públicas que a coloquem em prática.

Todos esses fatores apontados em relação as escolas multisseriadas são questões que afetam todo o processo de ensino e aprendizagem nas escolas do/no campo e, também, incidem nas práticas de alfabetização e letramento dos alunos. Dessa forma, devem ser pensadas políticas públicas que primem pela valorização e fortalecimento dos saberes que levem em consideração a apropriação da leitura e escrita de maneira que o sujeito do campo seja inserido em práticas sociais significativas e vinculadas ao seu lugar e sua vida, situação que se aproxima de alfabetizar/letrando.

\section{Referências}

BRASIL. Conselho Nacional de Educação Básica: Resolução CNEB/ CEB1, de 3 de abril de 2002. Diário Oficial da União, Brasília, 9 de abril de 2002. Seção 1.

BRASIL. Secretaria de Educação Básica. Diretoria de Apoio à Gestão Educacional. Pacto Nacional pela alfabetização na idade certa: currículo no ciclo de alfabetização: perspectiva para uma educação do campo. Educação do Campo: unidade 01. Ministério da Educação, Secretaria de Educação Básica, Diretoria de Apoio à Gestão Educacional. Brasília: MEC, SEB, 2012.

BRASIL. Secretaria de Educação Básica. Diretoria de Apoio à Gestão Educacional. Pacto Nacional Pela Alfabetização na Idade Certa: Apropriação 
do Sistema de escrita alfabética e a consolidação do processo de alfabetização em escolas do Campo - Caderno 03. Ministério da Educação, Secretaria de Educação Básica, Diretoria de Apoio à Gestão Educacional. Brasília: MEC, SEB, 2012.

BRASIL. Lei de Diretrizes e Bases da Educação Lei no 9.394/96, de 20 de dezembro de 1996. Brasília: Brasília: MEC, SEB, 1996.

FERREIRO, Emília; TEBEROSKY, Ana. Psicogênese da Língua Escrita. Porto Alegre: Artmed, 1999.

FERRI, Cássia. Classes multisseriadas: que espaço escolar é esse? Florianópolis: UFSC, 1994. Dissertação. Programa de Pós-Graduação em Educação da Universidade Federal de Santa Catarina/SC. Disponível em: https://repositorio.ufsc.br/xmlui/handle/123456789/76081. Acesso em: 22 mar. 2021.

LEAL, T. F; ALBUQUERQUE, E. B. C.; LEITE, T. B. S. R. Jogos: alternativas didáticas para brincar alfabetizando (ou alfabetizar brincando?). In: MORAIS, A. G. et al. Alfabetização: apropriação do sistema de escrita alfabética. Belo Horizonte: Autêntica, 2005.

MOLINARI, Cláudia. Entrevista concedida a Paola Gentile, de Buenos Aires, Argentina. Revista Nova Escola. 01 jan. 2009.

MORTATTI, Maria do Rosário Longo. Educação e letramento. São Paulo: UNESP, 2004.

MORTATTI, Maria do Rosário Longo. História dos métodos de alfabetização no Brasil. Conferência proferida durante o Seminário "Alfabetização e letramento em debate", promovido pelo Departamento de Políticas de Educação Infantil e Ensino Fundamental da Secretaria de Educação Básica do Ministério da Educação. Brasília, 2006. Disponível em: http://portal.mec. gov.br/seb/arquivos/pdf/Ensfund/alf_mortattihisttextalfbbr.pdf. Acesso em: 04 de abril 2019. 
ROSA, Ana Cristina Silva da. Classes multisseriadas: desafios e possibilidades. Educação \& Linguagem. Ano 11, n. 18, p. 222-237, jul./dez. 2008.

SÁ, Carolina Figueiredo de; PESSOA, Ana Cláudia Rodrigues Gonçalves. Práticas de alfabetização em turmas multisseriadas: estratégias docentes para lidar com a heterogeneidade de aprendizagens. 37a Reunião Nacional da ANPEd - 04 a 08 de outubro de 2015, UFSC - Florianópolis.

SÉRKEZ, Angela Maria Batista; MARTINS, Sandra Mara Bozza. Trabalhando com a valavra viva: sistematização da Língua Portuguesa através do texto. Curitiba: Renascer, 1996.

SOARES, Magda. Letramento: um tema em três gêneros. 3. ed. Belo Horizonte: Autêntica, 2009.

TFOUNI, Leda Verdani. Letramento e alfabetização. 9. ed. São Paulo: Cortez, 2010. 


\section{A IMPORTÂNCIA DOS CONCEITOS CIENTÍFICOS NO ENSINO DE MATEMÁTICA: UMA EXPERIÊNCIA DE IN- TERVENÇÃO PEDAGÓGICA NA EDUCAÇÃO NÃO-FOR- MAL EM PORTO VELHO/RO}

Rafael Fonseca de Castro

Divina Rogéria Corrêa Santos

\section{Introdução}

A História da Educação perpassa experiências e transformações que ocorreram desde o mundo antigo até os dias de hoje. A Educação não tem um destino certo, pois se faz numa construção social que se renova a cada dia, individual e coletivamente.

Antigamente, segundo Cambi (2002), os processos educativos eram ligados à vida cotidiana, inseridos nas práticas familiares, nas relações sociais, em rituais e cerimônias. Com o passar dos tempos, outros espaços, como as próprias casas das pessoas e os thyasos (cenáculos de amigos), até a idealização da escola, serviam de "espaço" para a Educação. Juntando-se à Filosofia e bebendo de fontes diversas, como as pesquisas social e material ligadas ao imaginário e conotadas pelo pluralismo, passando por Comênio, Rousseau e tantos outros, foi-se constituindo uma ideia de Educação cada vez mais estruturada até instituirmos escolas e universidades.

Percebe-se que a Educação tem, em suas bases históricas, experiências fora e dentro das instituições formais de ensino. De acordo com Cambi (2002), com a aceleração do desenvolvimento cultural e com a explosão tecnológica, mudanças expressivas vão afetando o cotidiano das pessoas e alterando os caminhos da humanidade. A Pedagogia, frente às mudanças da vida em sociedade e das desigualdades, reavalia-se, renova-se e se organiza levando em consideração os diversos espaços da vida cultural. Tendo em vista as emergentes possibilidades de atuação dos futuros profissionais da Educação, preparar 
professores para atuarem em múltiplos espaços, dentro e fora das escolas, passa a ser prerrogativa dos processos formativos. No curso de Pedagogia da Universidade Federal de Rondônia (UNIR), Campus Porto Velho, por exemplo, é ofertado o estágio em espaços não-escolares, propiciando experiências pedagógicas aos futuros professores fora do ambiente escolar.

Gohn (2016) sinaliza que práticas pedagógicas em espaços de Educação não-formal têm levado conhecimento ao cotidiano das pessoas, contribuindo com o desenvolvimento humano entre diversos grupos sociais - em geral, àqueles que não dispõem de acesso à Educação formal ou que precisam de suporte aos estudos realizados nas escolas.

Nesse contexto, a investigação ao qual este texto se refere se justifica pela carência de pesquisas sobre Educação não-formal no estado de Rondônia e o presente artigo apresenta um recorte dos resultados de uma pesquisa aplicada em um espaço de Educação não-formal na cidade de Porto Velho/RO, mediante o ensino de conceitos científicos (Vygotsky, 1934/1982) de Matemática para três crianças que cursavam o $4^{\circ}$ Ano do Ensino Fundamental (EF) e participavam do programa conhecido como PROFESP.

Esta investigação se filia, teórica e metodologicamente, à Teoria Histórico-Cultural da Atividade (CHAT), adotando os pressupostos das pesquisas do tipo intervenção pedagógica (Damiani et al., 2013), mediante abordagem qualitativa de coleta e análise de dados (Bauer; Gaskell, 2017), realizada de agosto a novembro de 2019. Baseamo-nos nos pressupostos vygotskianos de conceitos científicos e de Zona de Desenvolvimento Iminente (ZDI) (Vygotsky, 1934/1982; Prestes, 2010) e nos de Davydov (1988) sobre os conteúdos.

As pesquisas do tipo intervenção pedagógica, segundo Damiani et al. (2013), são investigações que envolvem o planejamento e a implementação de interferências (mudanças, inovações pedagógicas) destinadas a produzir avanços/aprimoramentos em processos educacionais e a avaliação dos seus efeitos ao final. Neste artigo, apresentamos e discutimos os efeitos da intervenção empreendida, destacando o trabalho pedagógico com conceitos científicos no ensino de Matemática. 


\section{Contribuições da teoria Histórico-Cultural da atividade à educação não-formal}

Um dos princípios basilares e consensual entre os autores fundadores da CHAT, e de pesquisadores contemporâneos filiados a essa corrente teórica, é a importância central da escola, do professor e dos conteúdos escolares para o desenvolvimento cognitivo das crianças - e também de adolescentes e adultos (Vygotsky, 1934/1982; Davydov, 1988; Prestes, 2010; Castro, 2014; Damiani et al., 2013).

Contudo, em países marcados por desigualdades como o Brasil, é fundamental levar em consideração todas as possibilidades de acesso ao conhecimento sistematizado desenvolvido historicamente pela humanidade às pessoas. Nesse sentido, a Educação não-formal pode ser uma aliada das instituições formais em casos em que o acesso à Educação ainda não acontece e/ou onde é precário. De acordo com Gohn (2016), foi a partir do século XX que se intensificou o interesse pedagógico pela Educação não-formal. Os estudos sobre essa temática não tinham muito espaço como objeto de estudo, mas, a partir dos anos 1990, o debate acadêmico passou a considerar o tema.

$\mathrm{Na}$ literatura acadêmica, atualmente, distinguem-se Educação formal, Educação não-formal e Educação informal: a Educação formal é desenvolvida em escolas, universidades e demais espaços institucionalizados, públicos ou privados, com conteúdos previamente estabelecidos e legislação específica orientadora; a Educação não-formal é a que se aprende com as experiências do mundo, presentes em espaços e ações coletivas do cotidiano, fora das instituições; e a Educação informal tem seus espaços educativos demarcados por referências de nacionalidade, localidade, idade, religião, etnia etc. - a rua onde se mora, o bairro, o condomínio, a igreja etc. (Gohn, 2016).

Vygotsky (1934/1982), Davydov (1988) e outros estudiosos soviéticos se interessavam pelo funcionamento cognitivo do ser humano, buscando a compreensão de um ser psicológico. Seus estudos perpassaram pelos processos neurofisiológicos até as relações entre o funcionamento intelectual e a cultura a qual os indivíduos fazem parte. As contribuições teórico-metodológicas da CHAT podem alcançar qualquer processo educacional, seja a modalidade ou espaço onde 
se materialize. A importância da aprendizagem dos conteúdos para o desenvolvimento cognitivo será a mesma em espaços de Educação não-formal. Para Davydov (1988), o saber contemporâneo pressupõe que o homem domine os processos de origem e desenvolvimento das coisas mediante o pensamento teórico, com seus tipos específicos de generalização e abstração. Segundo esse autor, Vygotsky (1934/1982) havia mostrado a relevância da escolarização para a aprendizagem dos conceitos científicos e para o desenvolvimento das capacidades de pensamento, a partir da apropriação da produção cultural da humanidade - o que também pode ocorrer em espaços não-escolares.

Castro (2014) explica que os estudos conduzidos pela escola de $\mathrm{Vy}$ gotsky destacam a peculiaridade da atividade de aprendizagem cujo objetivo é o domínio do conhecimento teórico, o domínio de símbolos e instrumentos culturais disponíveis na sociedade, obtidos pela aprendizagem de conceitos e procedimentos das diversas áreas do conhecimento. Apropriar-se desses conteúdos - das ciências, das artes, da moral, da Matemática - significa se apropriar das formas de desenvolvimento do pensamento.

Vygotsky (1934/1982) diferenciava os conceitos espontâneos, aqueles apreendidos do cotidiano, no dia-a-dia, daqueles aprendidos na escola, os científicos, sistematizados historicamente pela humanidade, frutos de estudos nas diversas áreas do conhecimento e transmitidos de geração em geração, fundamentalmente, por escolas e universidades. E, no sentido de podermos acompanhar o processo de desenvolvimento das crianças, Vygotsky (1934/1982) criou a metáfora da ZDI, que se refere aos conhecimentos que ainda estão em broto e que, aquilo que só conseguimos realizar hoje, com ajuda, poderemos realizar sozinhos amanhã - reforçando a importância da ajuda de alguém mais experiente para o avanço das crianças em suas ZDI. Já o conceito de Zona de Desenvolvimento Real (ZDR) foi criado por Vygotsky (1934/1982) para denominar aquilo que a criança já faz sozinha hoje sem ajuda. Prestes (2010) e Castro (2014) destacam que o ensino, para Vygotsky, deve estar direcionado prospectivamente, sempre àquilo que está na ZDI de cada estudante.

Passamos, a seguir, à pesquisa que desenvolvemos focada no ensino de conceitos científicos de Matemática por uma pesquisadora de nosso Grupo 
de Pesquisa ${ }^{1}$ que procurou atuar, ao longo da intervenção pedagógica, junto à ZDI das crianças participantes do estudo.

\section{Percurso investigativo}

A pesquisa foi realizada na cidade de Porto Velho, junto ao Programa Forças no Esporte (PROFESP), criado em 2003. O programa, que é destinado ao atendimento de crianças e jovens de ambos os sexos, de seis até 18 anos de idade, em situação de vulnerabilidade social, tem por finalidade promover a valorização da pessoa, reduzir riscos sociais e fortalecer a cidadania, a inclusão e a integração social de beneficiados, por meio do acesso à prática de atividades esportivas e de atividades socialmente inclusivas, realizadas no contraturno escolar.

Na cidade de Porto Velho, o PROFESP funciona desde 2013 e realiza suas atividades esportivas e acompanhamento escolar no período vespertino. As crianças que participavam do projeto todas as terças e quintas-feiras frequentavam a E.E.E.F. Maria Isaura da Costa Cruz na época da pesquisa, no período matutino. Os participantes da intervenção foram três crianças ${ }^{2}$, com idade entre nove e dez anos, que cursavam o $4^{\circ}$ Ano do EF, selecionados de forma intencional pelo monitor do projeto por apresentarem dificuldades em aprender conceitos básicos de Matemática para a faixa etária e por se mostrarem motivados, entre as crianças observadas, em participarem das atividades.

As intervenções pedagógicas, segundo Damiani et al. (2013), têm por objetivo não só ampliar conhecimentos, mas contribuir com a superação de problemas práticos na área educacional. Essas pesquisas ligam a produção acadêmica à prática educacional, fornecendo subsídios para o aprimoramento de

1 Investigação desenvolvida no âmbito do Grupo de Pesquisa "HISTCULT - Educação, Psicologia Educacional e Processos Formativos” da UNIR que integra o Projeto de Pesquisa "Intervenções Pedagógicas em Rondônia: inovação educacional e produção de conhecimento em Educação” (Portaria no 81/2019/PROPESQ/UNIR). Este projeto está vinculado ao Programa de Pesquisa "Educação e Psicologia Histórico-Cultural: investigações teórico-práticas de processos educativos na Amazônia Ocidental” (Portaria no 70/2019/PROPESQ/UNIR). Mais detalhes em: http://www.histcult.unir.br.

2 A pesquisadora atuou somente após a devida autorização dos responsáveis pelo projeto, estando todos os documentos contidos e disponíveis em Santos (2019). Por questões de confidencialidade, seus nomes reais não foram revelados. Foram adotados nomes fictícios em homenagem aos autores da literatura infantil Mary França, Eliardo França e Mike Gordon. 
ações pedagógicas e dando suporte a políticas educacionais. A presente intervenção se baseou na proposta de trabalhar pedagogicamente com as operações matemáticas utilizando ferramentas e abordagens didáticas atrativas à apropriação do conhecimento científico pelas crianças, totalizando sete etapas interventivas, entre os meses de agosto e novembro de 2019.

A intervenção foi planejada com o intuito de trabalhar pedagogicamente conceitos matemáticos de forma contextualizada, com mediação constante da pesquisadora e no sentido de fazer as crianças avançarem nas suas ZDI (Vygotsky, 1934/1982; Prestes, 2010) quanto aos conhecimentos sobre cada operação. Um dos focos de todo o percurso foi o estímulo ao pensamento lógico-abstrato (Davydov, 1988) como superação dos esquemas de memorização. A intervenção pedagógica foi dividida em: diagnóstico pré-intervenção e sete etapas interventivas, a saber.

Diagnóstico pré-intervenção (agosto): aproximação, diálogo inicial com as crianças, seleção dos participantes e escolha, em conjunto, das temáticas de estudo. As crianças escolheram estudar divisão; etapa interventiva 1 (10/09/2019): conceitos de unidade, adição, dezena, centena e milhar; etapa interventiva 2 (26/09/2019): retomada e sistematização dos conteúdos prévios, adição com reagrupamento e subtração; etapa interventiva $3(03 / 10 / 2019)$ : multiplicação; etapa interventiva 4 (08/10/2019): retomada e sistematização dos conteúdos prévios, divisão (euclidiana, divisor, dividendo, quociente e resto), para todos, e explicação dos conceitos da multiplicação para Mary (que havia faltado no dia anterior); etapa interventiva 5 (15/10/2019): retomada dos conceitos, exercícios e revisão sobre divisão, abordando subtração e multiplicação; etapa interventiva 6 (24/10/2019): revisão sobre divisão com incentivo ao pensamento lógico-abstrato; etapa interventiva 7 (05/11/2019): revisão final dos conceitos científicos e exercícios relacionados às quatro operações.

O levantamento e a interpretação dos dados da pesquisa foram realizados mediante abordagem qualitativa (Bauer; Gaskell, 2017). A coleta dos dados para a avaliação da intervenção incluiu entrevista, observação participante da pesquisadora e análise documental dos exercícios realizados pelas crianças. Os dados foram sendo coletados no percurso das etapas interventivas 
conforme seu desenrolar, sendo constante a observação pela pesquisadora das atividades desenvolvidas.

A análise dos dados foi organizada segundo pressupostos da análise textual discursiva (Moraes, 2003), sendo os dados Unitarizados, Categorizados e, depois, escrito o Metatexto. A seguir, destacamos os resultados relacionados às aprendizagens das crianças de conceitos relacionados às quatro principais operações matemáticas, a partir das atividades interventivas.

\section{Aprendizagens de conceitos científicos das operações matemáticas: avan- ços e dificuldades}

O tratamento e a interpretação dos dados seguiram as etapas da análise textual discursiva (Moraes, 2003). Após a Unitarização, os dados foram organizados e divididos em duas categorias de análise: "aprendizagens de conceitos científicos das quatro principais operações matemáticas" e "avaliação da intervenção". Para o presente recorte, devido às limitações de espaço, apresentaremos e discutiremos apenas a primeira.

A participante Mary foi a que mais chamou a atenção desde o início, pois cursava o $4^{\circ}$ ano do $\mathrm{EF}$ e, na resolução de exercícios de divisão na etapa pré-interventiva, não conseguiu dividir nem mesmo seis por dois. Conforme é possível observar na Figura 1, no exercício um, Mary já demonstrava que não sabia efetuar divisões. Percebemos que, por não estar conseguindo resolver os exercícios inicialmente propostos, parecia estar em conflito e se mostrou dispersa, olhando em volta para as crianças que estavam à mesa e mexia aletoriamente no lápis. Também olhava para Eliardo e para Mike, que estavam resolvendo os exercícios. Nas respostas ao exercício 1, (b) e (c) do item 2, esperou até o momento em que conseguiu copiar a resposta do colega ao lado para responder. 
Figura 1 - Exercícios de divisão realizados por Mary na pré-intervenção.
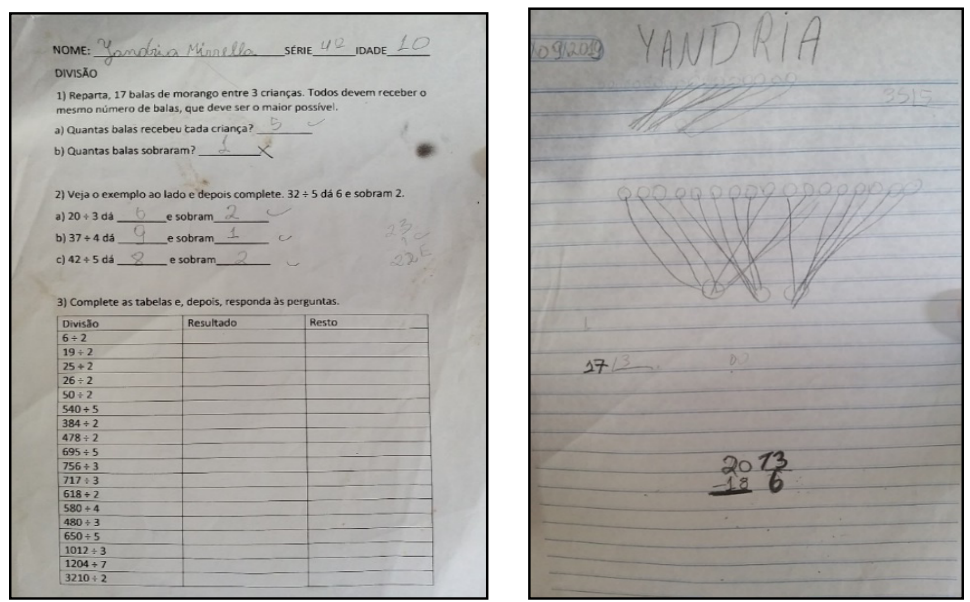

Fonte: Acervo da pesquisa (2019).

Durante a primeira etapa interventiva, a pesquisadora explicou os conceitos de unidade, dezena, centena e adição e Mary não possuía conhecimento científico algum sobre esses conceitos. Após as explicações, foi possível observar que Mary conseguiu resolver os exercícios sem apresentar erros. Quando chegou no exercício 5, ela deveria classificar o número 18 em unidade e dezena. Foi mostrado a ela o número com o material dourado e, então, foi perceptível que Mary entendera os conceitos de unidade, dezena e centena. Após esse entendimento, passou a resolver os exercícios demonstrando maior segurança no que estava fazendo, revelando avanço desse conceito em sua ZDI, mesmo que ainda apresentando dúvida se o que havia pensado estava correto.

Também verificamos que ela resolveu os exercícios 2, 3 e 4 sem tirar dúvidas e acertou todos eles. Esses resultados sugerem que ela se apropriou dos conceitos ensinados na primeira etapa interventiva. Já tendo compreendido os conceitos de unidade, dezena, centena e adição, na segunda etapa interventiva, o conteúdo trabalhado foi adição com reagrupamento. Terminadas as explicações, notamos que Mary resolveu mais uma vez os exercícios sem fazer quaisquer perguntas, indicando importante avanço. De doze exercícios propostos nesse ponto da intervenção, ela errou apenas um, conforme ilustra a Figura 2. Ainda na segunda etapa, foi trabalhado o conteúdo subtração com 
desagrupamento e Mary resolveu doze (errou três) sem fazer perguntas ou pedir ajuda à pesquisadora, sugerindo apropriação dos conceitos de subtração e desagrupamento.

Figura 2 - Exercícios adição com reagrupamento realizados por Mary.

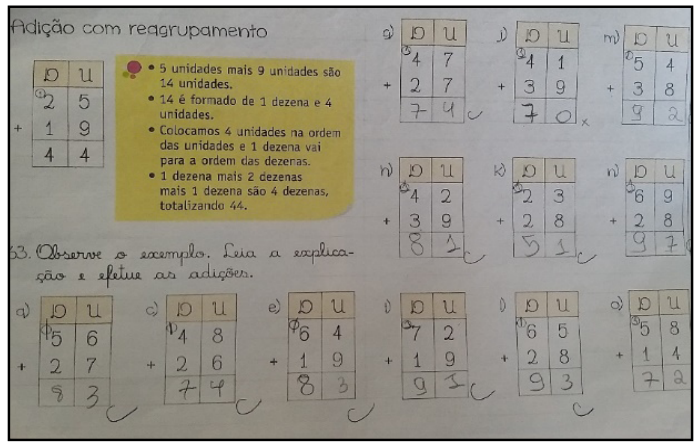

Fonte: Acervo da pesquisa (2019).

Dando sequência à intervenção, na etapa quatro, a pesquisadora acordou com Mary que, após a explicação do conceito da divisão, explicar-lhe-ia o de multiplicação, pois ela havia faltado à etapa interventiva três. Quanto aos exercícios de divisão, de seis, ela errou somente um. As divisões que possuíam dois números no divisor exigiram mais do raciocínio de Mary, que demorou mais para solucioná-los e, então, pediu a ajuda da pesquisadora em alguns momentos, sublinhando a importância do professor, da pessoa mais experiente, conforme é expresso por Vygotsky (1934/1982) no conceito de ZDI.

Nas etapas interventivas cinco e seis, a pesquisadora trabalhou com uma folha com 30 exercícios de divisão com o intuito de avaliar a apropriação, pelas crianças, das quatro operações. Nesse ponto, Mary ainda apresentava dificuldades, mas era nítido seu avanço em termos de conhecimentos científicos relacionados às operações, tendo resolvido com autonomia 18 exercícios (apenas três errados) sem solicitar ajuda à pesquisadora. $\mathrm{Na}$ etapa final, demonstrou bom desempenho resolvendo cinco exercícios de cada uma das operações, errando apenas um exercício de divisão: 
Figura 3 - Exercícios com as quatro operações matemáticas realizados por Mary.

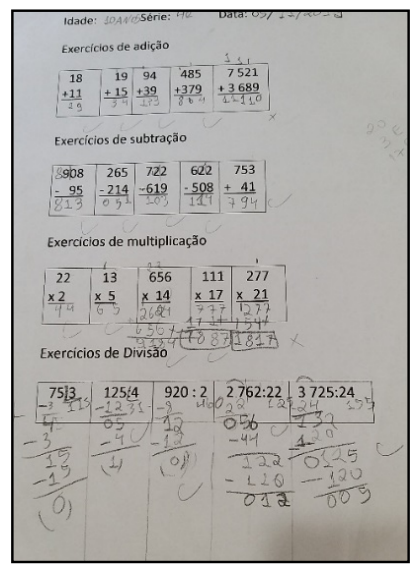

Fonte: Acervo da pesquisa (2019).

Ao considerar o início da intervenção, quando Mary detinha conhecimento precário acerca das operações matemáticas principais, sem compreensão alguma dos conceitos científicos e da lógica dessas operações, ao final do processo interventivo, parece-nos clara a sua evolução em termos dos conteúdos que implicam na resolução dessas operações, pois não mais recorreu ao uso mecânico das bolinhas para resolver os exercícios. $\mathrm{Na} \mathrm{Ta}-$ bela 1, verificamos o quanto a Mary avançou em divisão. No início da intervenção, ela acertava apenas $20 \%$ dos exercícios que conseguiu resolver. Ao final, elevou para 80 o percentual de acerto.

Quadro 1 - Resultado final dos exercícios de divisão de Mary.

\begin{tabular}{|c|c|c|c|c|}
\hline Mary & $\begin{array}{c}\text { Exercícios de } \\
\text { divisão }\end{array}$ & Acertos & Erros & \% \\
\hline Etapa pré-intervenção & 5 & 1 & 4 & 20 \\
\hline Etapa interventiva 4 & 6 & 5 & 1 & 83 \\
\hline Etapa interventiva 5 e 6 & 18 & 15 & 3 & 83 \\
\hline Etapa interventiva 7 & 5 & 4 & 1 & 80 \\
\hline
\end{tabular}

Fonte: Banco de dados da pesquisa (2019). 
No caso do participante Eliardo, na primeira etapa interventiva, durante a explicação dos conceitos de unidade, dezena, centena e adição, ficou perceptível que ele não possuía nenhum conhecimento a respeito de unidade, dezena, centena e da palavra adição. Ele entendia o que era "continha de mais”, mas não conhecia o termo científico de adição (adicionar). Questionado se havia compreendido a explicação sobre adição, ele respondeu que sim, mas, como na etapa pré-intervenção, conseguiu resolver apenas seis exercícios. Nas primeiras atividades, Eliardo fez o uso das bolinhas e da divisão euclidiana, conforme ilustra a Figura 4:

Figura 4 - Exercícios de divisão pré-intervenção de Eliardo.
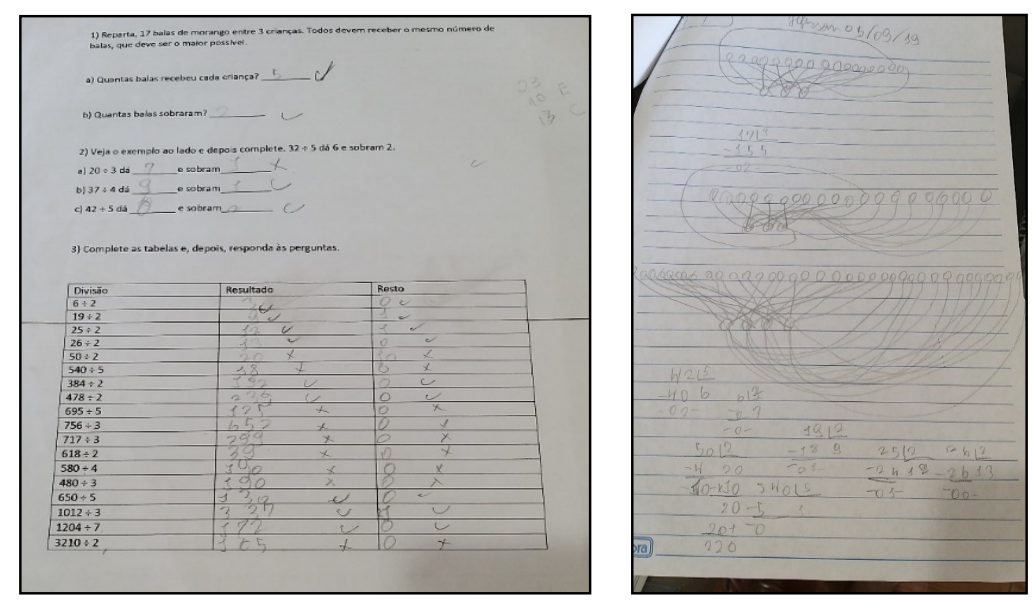

Fonte: Acervo da pesquisa (2019).

$\mathrm{Na}$ segunda etapa da intervenção, durante a explicação sobre subtração com desagrupamento, Eliardo não conseguiu responder a nenhuma das perguntas durante a fala da pesquisadora - que percebeu o fato de ele não compreender nem os conceitos implicados nem a lógica da operação. No entanto, após nova intervenção da pesquisadora, pareceu compreender a lógica dessa operação. Dos 27 exercícios, não errou nenhum e não fez mais perguntas à pesquisadora após o término da explicação sobre o conteúdo adição com reagrupamento. Eliardo respondeu as questões rapidamente e as entregou à pesquisadora. Percebendo que um exercício estava errado, a 
pesquisadora chamou a sua atenção. Eliardo olhou novamente o exercício, apagou o que havia escrito e resolveu novamente a questão, desta vez, corretamente. A Figura 5 ilustra seu desempenho:

Figura 5 - Exercícios de subtração com desagrupamento de Eliardo.

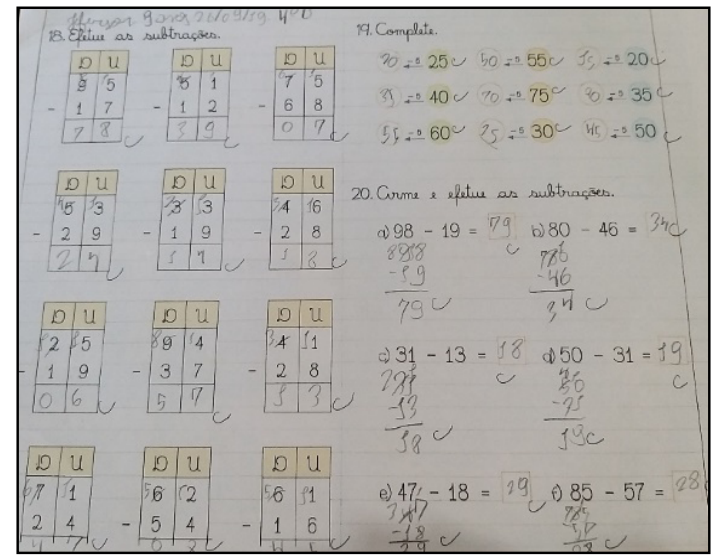

Fonte: Acervo da pesquisa (2019).

$\mathrm{Na}$ terceira etapa interventiva, quando trabalhados os conteúdos sobre multiplicação, novamente, após explicações e intervenções pontuais da pesquisadora, Eliardo compreendeu a lógica imbricada na operação e, após refazer os primeiros exercícios, conseguiu concluir a atividade. Todavia, apresentou mais dificuldades na quarta etapa interventiva, quando o conteúdo trabalhado era a operação de divisão. Eliardo precisou ser alertado pela pesquisadora sobre não esquecer dos decimais, da vírgula e do zero no quociente, quando precisasse. Então, resolveu os exercícios, mesmo os refazendo diversas vezes. O estudante ainda estava com os conhecimentos sobre divisão em broto, sendo necessário o apoio constante da pesquisadora, a pessoa mais experiente contextualizada por Vygotsky (Vygotsky, 1982/1934; Prestes, 2010; Castro, 2014). Com o apoio da pesquisadora, mediante suas intervenções, Eliardo, enfim, apropriou-se dos conceitos necessários à compreensão da lógica da operação de divisão, deixando de fazer uso do recurso mecânico das bolinhas e avançando ao pensamento abstrato. Ainda assim, nem em todas as ocasiões e ainda não demonstrando segurança. 
Nas etapas interventivas cinco e seis, durante a resolução da atividade com 30 exercícios de divisão, ele acertou 23. Na etapa final, como mostra a Figura 6, na tarefa contendo cinco exercícios de cada operação, dos 20 exercícios, ele errou dois, ambos de divisão, evidenciando que os conhecimentos científicos específicos dessa operação, mesmo que tivessem avançado em sua ZDI, ainda não estavam consolidados em sua ZDR (Vygotsky, 1934/1982).

Figura 6 - Exercícios final com as quatro operações matemáticas de Eliardo.

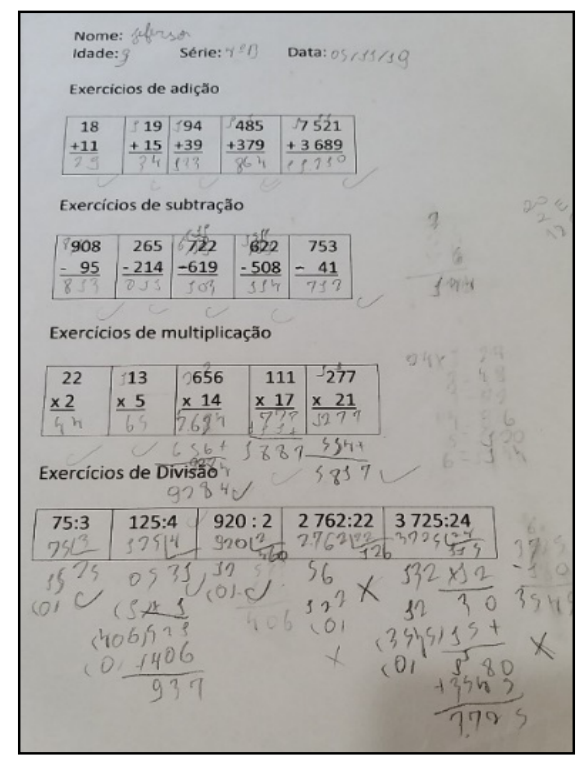

Fonte: Acervo da pesquisa (2019).

Ao longo de toda a intervenção pedagógica, percebemos avanços inegáveis de Eliardo, partindo do diagnóstico inicial de conhecimentos matemáticos bastante restritos. Observamos, desde o início, que esse estudante não se baseava em nenhum conhecimento matemático abstrato ou em pensamento lógico na resolução dos exercícios pré-intervenção. Com o passar das atividades, e com as constantes intervenções da pesquisadora, ele se apoiou cognitivamente no pensamento abstrato para a resolução das operações, não fazendo mais uso do esquema das bolinhas, como a colega Mary. No entanto, Eliardo não foi tão além como Mary em termos de pensamento matemático abstrato, como podemos verificar nos resultados finais de acertos em exercícios de divisão expressos 
na Tabela 2. Não são tão expressivos quanto os de Mary, pois Eliardo fazias com pressa as atividades, refletindo em erros:

Quadro 2 - Resultado final dos exercícios de divisão de Eliardo.

\begin{tabular}{|c|c|c|c|c|}
\hline Eliardo & $\begin{array}{c}\text { Exercícios de } \\
\text { divisão }\end{array}$ & Acertos & Erros & \% \\
\hline Etapa pré-intervenção & 23 & 13 & 10 & 56 \\
\hline Etapa interventiva 4 & 8 & 6 & 2 & 75 \\
\hline Etapa Interventiva 5 e 6 & 30 & 23 & 7 & 76 \\
\hline Etapa intervenção 7 & 5 & 3 & 2 & 60 \\
\hline
\end{tabular}

Fonte: Banco de dados da pesquisa (2019).

Quanto ao estudante Mike, na primeira etapa interventiva, durante a atividade acerca dos conceitos de unidade, dezena, centena e adição, também avaliamos que não possuía nenhum conhecimento científico sobre as operações. Ele não respondeu a nenhuma das perguntas iniciais. Quando perguntado se havia entendido as explicações sobre adição, ele respondeu apenas que sim.

Mike também era considerado um dos melhores estudantes da sua turma em Matemática, entretanto, durante o acompanhamento dos exercícios pré-intervenção de divisão, observamos que ele usa a divisão euclidiana sem compreender a lógica matemática, pois, errava quando o número possuía centenas e unidades de milhar no dividendo (cf. Figura 7):

Figura 7 - Exercícios de divisão pré-intervenção de Mike.
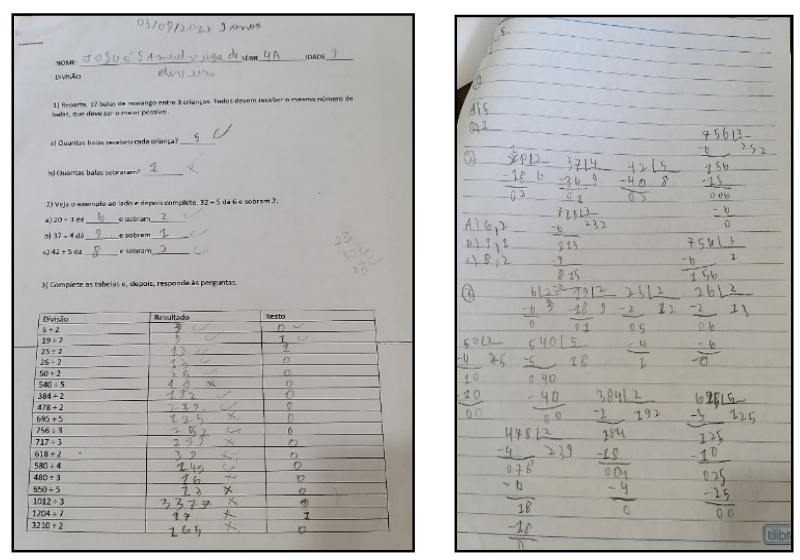

Fonte: Acervo da pesquisa (2019). 
$\mathrm{Na}$ segunda etapa interventiva, quando o conteúdo abordado foi adição com reagrupamento, observamos que Mike respondeu as questões rapidamente e logo entregou a folha de exercícios à pesquisadora tendo acertado os doze exercícios que foram propostos. Ainda nessa etapa, foi trabalhada a subtração com desagrupamento e, Mike, mais uma vez, durante a explicação da professora-pesquisadora, não conseguiu responder a nenhuma das perguntas. Ficou nítido que ele não dominava noções mínimas dos conceitos explicados nem a lógica por trás deles. Todavia, após uma nova explicação da pesquisadora, ele resolveu os 27 exercícios da folha e acertou todos.

$\mathrm{Na}$ terceira etapa interventiva, no âmbito do conteúdo multiplicação, Mike realizou todos os exercícios e só errou no exercício 2, letra i. No exercício nove, ele encontrou a mesma dificuldade de Eliardo e, no exercício seis, ao ouvir a explicação da pesquisadora à Eliardo, apagou e refez as letras a e b, conforme mostra a Figura 8:

Figura 8 - Exercícios de multiplicação realizados por Mike.
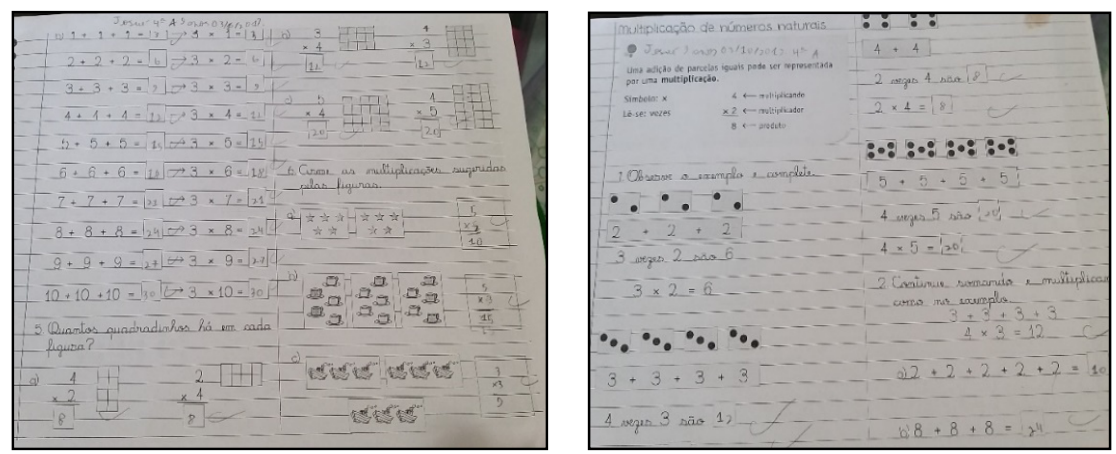

Fonte: Acervo da pesquisa (2019).

$\mathrm{Na}$ quarta etapa interventiva, após as explicações sobre o conteúdo de divisão, Mike começou a resolver os exercícios de forma inquieta, parecendo querer resolver todos muito rapidamente. Após intervenções da pesquisadora, indicando novamente a importância da professora como mediadora dos processos de aprendizagem dos estudantes, tal como Vygotsky (1934/1982) apregoava quando propôs o conceito de ZDI (Prestes, 2010), ele passou a pensar mais calmamente, o que acreditamos ter influenciado no seu bom desempenho 
nesse ponto da intervenção. Os exercícios que Mike errou se limitaram àqueles em que precisou entrar na casa decimal, sugerindo conhecimentos ainda em broto na ZDI (Vygotsky, 1934/1982).

No entanto, nas etapas interventivas cinco e seis, dos 30 exercícios de divisão, Mike errou 18 (cf. Figura 9). Ele parecia afobado na hora de pensar sobre os exercícios propostos, "afastando-se" do pensamento lógico, o que, segundo nossa avaliação, levou-o aos erros.

Figura 9 - Exercícios de divisão respondidos por Mike.

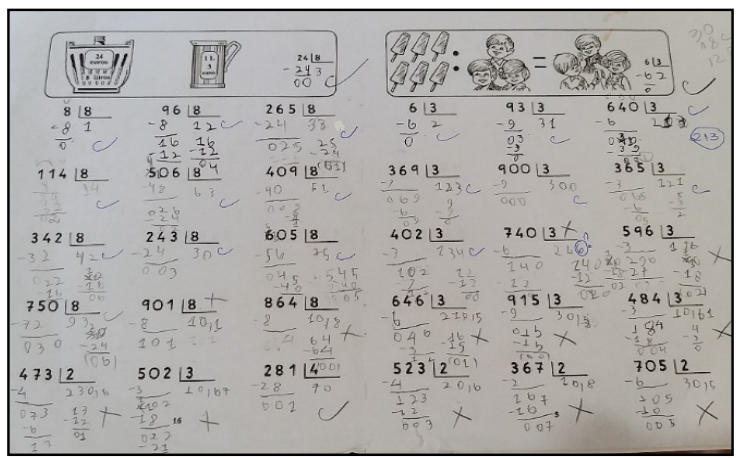

Fonte: Acervo da pesquisa (2019).

$\mathrm{Na}$ etapa final, todos receberam uma lista com 20 exercícios contendo cinco de cada operação. Mike errou três, todos de divisão. Durante toda a intervenção percebemos a fragilidade dos conhecimentos de Mike sobre os conceitos das operações básicas da Matemática e da lógica na resolução dos exercícios. Ele não fez o uso das bolinhas, usando a forma euclidiana para resolver as atividades de divisão, mas observamos que não entendia o porquê a usava. Na pré-intervenção, Mike já demonstrava não ter noção da lógica implicada na divisão euclidiana, mas, após explicações da pesquisadora, pareceu ter se apropriado dos conceitos, porém, no ímpeto de competir com Eliardo, querendo terminar os exercícios mais rápido que o colega, errava. Quando era chamada a sua atenção, pensava e refazia o exercício com êxito.

No entanto, ele parecia se apropriar dos conceitos de forma bastante vinculada à ajuda da pesquisadora. $\mathrm{O}$ novo conhecimento, recém adquirido (ainda em broto), pareceria fazer sentido, mas por não estar habituado a pensar 
abstratamente, trata-se de um processo lento de desenvolvimento. A Tabela 3 ilustra a inconstância de Mike durante a intervenção, tendo em vista que iniciou acertando $56 \%$ dos exercícios de divisão e encerrou acertando 40\%:

Quadro 3 - Resultados dos exercícios de divisão de Mike.

\begin{tabular}{|c|c|c|c|c|}
\hline Mike & Exercícios de divisão & Acertos & Erros & $\mathbf{\%}$ \\
\hline Etapa pré-intervenção & 23 & 13 & 10 & 56 \\
\hline Etapa interventiva 4 & 8 & 6 & 2 & 75 \\
\hline Etapa interventiva 5 e 6 & 30 & 18 & 12 & 60 \\
\hline Etapa interventiva 7 & 5 & 2 & 3 & 40 \\
\hline
\end{tabular}

Fonte: Banco de dados da pesquisa (2019).

Percebemos, ao longo de todo o processo interventivo, que as crianças participantes da pesquisa passaram a tomar consciência (Castro, 2014) de procedimentos e conhecimentos necessários à resolução dos exercícios das quatro operações matemáticas trabalhados pedagogicamente pela pesquisadora. Também constatamos o quanto o trabalho com os conceitos científicos (Vygotsky, 1934/1982) de Matemática os fez evoluir em termos de pensamento lógico-abstrato, sublinhando a importância dos conteúdos escolares para o desenvolvimento intelectual dos estudantes, tal qual destacava Davydov (1988). Contudo, a intervenção se constituiu em um momento breve de trabalho pedagógico junto a essas crianças, sendo necessário mais tempo para observar aprendizagens e desenvolvimento intelectual de forma mais consistente, considerando dificuldades, potencialidades e limitações de cada um.

\section{Considerações finais}

Foi possível verificar que a intervenção pedagógica em um espaço de educação não-formal contribuiu com a aprendizagem das crianças participantes, que elas avançaram conhecimentos matemáticos em suas ZDI (Vygotsky, 1934/1982; Prestes, 2010), a partir de conceitos científicos básicos relacionados às quatro operações: adição, subtração, multiplicação e divisão. Durante as atividades, foi perceptível que elas tomaram consciência (Castro, 2014) de conceitos importantes, conforme observado pela pesquisadora durante a realização dos exercícios ao longo de todo o processo interventivo. 
Mary avançou mais do que Eliardo, que avançou mais do que Mike. Os três participantes, no decorrer das etapas interventivas, evidenciaram que os conhecimentos elementares foram substituídos por conhecimentos científicos e que Mary avançou mais por ser mais cautelosa ao raciocinar durante a resolução dos exercícios, enquanto os meninos eram afoitos na resolução, acometendo em mais erros. Situação normal, se partirmos do pressuposto de que as pessoas aprendem em ritmos diferentes e que as experiências e aprendizagens pregressas se constituem e se desenvolvem no plano ontogenético específico de cada criança.

Com o passar das atividades, eles esperavam ansiosos pela pesquisadora e pela atividade de Matemática do dia, o que também despertou interesse em outras crianças que frequentavam o PROFESP de Porto Velho na época. Todavia, como fragilidade da intervenção, podemos destacar a periodicidade dos encontros, que poderiam ter ocorrido em dias mais próximos. Contudo, as agendas do programa e da pesquisadora não permitiram que isso ocorresse.

Mesmo com essa limitação, consideramos que esta primeira experiência de intervenção pedagógica na Educação não-formal produziu achados que nos permitem afirmar que as atividades didáticas colaboraram para a compreensão da lógica das operações pelos participantes e endossar a defesa do trabalho pedagógico com conceitos científicos, tanto no que se refere a aprendizagens de conteúdos de Matemática como para o desenvolvimento intelectual de nossas crianças, seja na escola ou em espaços de educação não-formal.

\section{Referências}

BAUER, Martin. W.; GASKELL, George. (orgs.). Pesquisa qualitativa com texto, imagem e som: um manual prático. 6. ed. Petrópolis: Vozes, 2017.

CAMBI, Franco. História da Pedagogia. 2. ed. São Paulo: Unesp, 2002.

CASTRO, Rafael F. de. A expressão escrita de acadêmicas de um curso de Pedagogia a distância: uma intervenção Histórico-Cultural. 2014. 238f. Tese (Doutorado) - Programa de Pós-Graduação em Educação. Universidade Federal de Pelotas, Pelotas, Brasil.

DAMIANI, Magda Floriana et al. Discutindo pesquisas do tipo intervenção pedagógica. Cadernos de Educação, Pelotas, v. 45, n.1, p. 1-22, 2013. Dis- 
ponível em: https://periodicos.ufpel.edu.br/ojs2/index.php/caduc/article/ view/3822/3074. Acesso em: 23 mar. 2021.

DAVYDOV, Vasily Vasilovich. La enseñanza escolar y el desarrollo psíquico. Havana: Editorial Progresso. 1988.

GOHN, Maria da Glória. Educação não formal e o educador social: atuação no desenvolvimento de projetos sociais. São Paulo: Cortez, 2016.

MORAES, R. Uma tempestade de luz: a compreensão possibilitada pela análise textual discursiva. Ciência e educação. Bauru, v. 9, n. 2, p.191-211, 2003. Disponível em: https://www.scielo.br/pdf/ciedu/v9n2/04.pdf. Acesso em: 23 mar. 2021.

PRESTES, Zoia Ribeiro. Quando não é quase a mesma coisa: análise de traduções de Lev Semionovitch Vigotski no Brasil. 2010. 232f. Tese (Doutorado) - Programa de Pós-Graduação em Educação. Universidade Federal de Brasília, Brasília, Brasil. Disponível em: https://repositorio.unb.br/bitstream/10482/9123/1/2010_ZoiaRibeiroPrestes.pdf. Acesso em: 23 mar. 2021.

SANTOS, Divina Rogéria C. Intervenção pedagógica na educação não-formal: uma proposta junto a crianças do PROFESP na cidade de Porto Velho/ RO. 2019. 99f. Trabalho de Conclusão de Curso (Licenciatura em Pedagogia) - Universidade Federal de Rondônia, Porto Velho, 2019.

VYGOTSKY. Lev Semenovich. Obras escogidas tomo II (Pensamiento Y Lenguaje). Moscú: Editorial Pedagógica, 1934/1982. 


\section{EDUCAÇÃO EM TEMPO INTEGRAL: ESTUDO EM ES- COLAS DA REDE ESTADUAL DE SANTARÉM-PARÁ}

Maria Sousa Aguiar

Maria Lília Imbiriba Sousa Colares

\section{Introdução}

A construção de ações, programas e políticas públicas com base na educação integral emergiu das demandas dos movimentos sociais. Arroyo (2012) interpreta os Programas Mais Educação, Escola de Tempo Integral e Escola Integrada como tentativas de respostas públicas a esses movimentos para garantir o direito à educação em tempos-espaços mais dignos. Para ele, isso seria o sentido político-pedagógico desses programas, que se espera que seja assumido como políticas de Estado. Considerando que são programas que se propõem a garantir o direito à educação e ao tempo de escola, Arroyo (2012) sugere que eles terão de afirmar-se como políticas afirmativas e situar-se no novo contexto político de contraposição às visões negativas que os reduzem às políticas compensatórias.

Neste sentido, este estudo, parte integrante das análises realizadas na dissertação intitulada "Educação em tempo integral: estudo da trajetória do Programa Mais Educação (PME) nas escolas estaduais de Santarém - PA no período de 2009 a 2015 "1 objetivou, neste recorte, analisar a trajetória do PME em duas escolas estaduais de Santarém no período de 2009 a 2015. O recorte temporal compreendeu o período do marco inicial da adesão das escolas estaduais de Santarém ao Programa Mais Educação e o ano de apresentação do

${ }^{1}$ Inserida na linha de pesquisa História, Política e Gestão Educacional na Amazônia e vinculada ao Projeto "As experiências pedagógicas das políticas de Educação Integral na Amazônia: rede de pesquisa e formação", do grupo de estudo do Programa Nacional de Cooperação Acadêmica (Procad), tendo como referência os estados de Rondônia, Pará e Amazonas, integrado à rede de professores pesquisadores da Universidade Estadual de Campinas (Unicamp), da Universidade Federal de Rondônia (UNIR) e da Universidade Federal do Oeste do Pará (Ufopa). 
projeto de pesquisa e ingresso no curso de Mestrado em Educação. Teve como problemática central a reflexão em torno de "como o PME foi implementado nas escolas estaduais de Santarém? ”. Para responder esta questão, realizamos a pesquisa com base no levantamento e estudo sistemático da literatura sobre a Educação integral e em tempo integral e sobre o Programa Mais Educação. Dentre os referenciais teóricos, foram utilizados os estudos de Arroyo (2012); Cavaliere (2007); Coelho (2009); Gadotti (2009); Gonçalves (2006); Libâneo (2015); Moll (2012); Paro (2009); Pegorer (2014); Saviani (2013) e documentos legais que tratam sobre o PME.

A pesquisa de campo ocorreu em duas escolas estaduais, de ensino fundamental, localizadas na área urbana do município de Santarém, denominadas nesta pesquisa com códigos (A e B) para manter o sigilo e a integridade ética das instituições, assim como dos profissionais envolvidos. Para a coleta de dados, utilizou-se como técnicas e instrumentos a análise documental e entrevistas semiestruturadas com os sujeitos da pesquisa. $\mathrm{Na}$ análise documental, além do Projeto Político-Pedagógico (PPP), foram consultadas as Prestações de contas do $\mathrm{PME}^{2}$ (2009-2015); informações sobre o quantitativo ${ }^{3}$ de alunos matriculados em cada escola e os resultados e metas do Índice de Desenvolvimento da Educação Básica (Ideb) das escolas.

Os sujeitos da pesquisa foram 03 (três) diretoras, 04 (quatro) coordenadores ${ }^{4}$ do Programa Mais Educação que atuaram nas escolas pesquisadas, e uma Técnica de referência do programa da $5^{\text {a }}$ Unidade Regional de Educação (URE), totalizando 08 (oito) educadores, sendo 03 (três) da Escola A e 04 (quatro) da Escola B. Para garantir o sigilo da identificação dos participantes da pesquisa, eles foram tratados por códigos organizados da seguinte maneira: A primeira letra representa o nome das escolas (A ou B), a segunda letra indica a função do sujeito (C para Coordenador e D para Diretor) e

2 Foram consultadas as Prestações de contas do PME somente da Escola A, pois a direção da Escola B não disponibilizou essa documentação.

3 Disponível em: http://www.seduc.pa.gov.br/portal/escola/consulta_matricula/RelatorioMatriculas.php? codigo_ure=5\&codigo_municipio $=44997$.

4 Neste estudo o termo coordenador do Programa Mais Educação será utilizado como correspondente ao professor comunitário. Portanto, não dizem respeito aos interlocutores das escolas e secretarias junto ao MEC. 
o número representa a quantidade de sujeito entrevistado, na ordem consecutiva do período cronológico em que atuou na escola. Os sujeitos foram identificados assim: AD1 - Diretora da Escola A; AC1 e AC2 - Coordenadores da Escola A; BD1 e BD2 - Diretoras da Escola B; BC1 e BC2 Coordenadores da Escola B. Para interpretação e análise das informações coletadas, utilizou-se o método de análise de conteúdo.

O texto encontra-se subdividido em duas seções, além da introdução e considerações finais. Inicialmente apresentamos o PME e a ampliação do tempo escolar na rede estadual de ensino do município de Santarém-Pará e, posteriormente, discorremos sobre a implementação do PME nas vozes dos educadores.

\section{O Programa Mais Educação (PME) e a ampliação do tempo escolar na Rede Estadual de Santarém-Pará}

No segundo mandato do governo de Luiz Inácio Lula da Silva (20072010), o Ministério da Educação (MEC) lançou, em 2007, o Plano de Desenvolvimento da Educação (PDE), com o objetivo de mobilizar os entes federados visando a melhoria na qualidade da educação nas instituições públicas. Compondo uma das ações do PDE, o PME foi instituído por meio da Portaria Interministerial n. 17, de 24 de abril de 2007, e pelo Decreto n. 7.083, de 27 de janeiro de 2010, como uma estratégia do Governo Federal para induzir a ampliação da jornada escolar e a organização curricular, com o intuito de fomentar a educação integral por meio do apoio a atividades socioeducativas no contraturno escolar.

O Decreto n. 7.083/2010 (Brasil, 2010a, p. 01) aprofundou a finalidade e objetivos do Programa Mais Educação. No seu Art. 1º, a normativa preconiza que a finalidade do programa é "[...] contribuir para a melhoria da aprendizagem por meio do tempo de permanência de crianças, adolescentes e jovens matriculados em escola pública, mediante oferta de educação básica em tempo integral". Apresenta como um dos seus objetivos "formular política nacional de educação básica em tempo integral" (Art. $3^{\circ}$, inciso I). A principal referência do $\mathrm{PDE}$, em termos de legislação, foi o Decreto n. 
6.094, de 24 de abril de 2007 (Brasil, 2007), que dispôs sobre a implementação do Plano de Metas Compromisso Todos pela Educação. Em relação à orientação da política educacional, duas medidas se destacam no PDE: a necessidade da utilização do Índice de Desenvolvimento da Educação Básica (Ideb) e a elaboração do Plano de Ações Articuladas (PAR), de acordo com os padrões definidos pelo Ministério da Educação.

Segundo o Ministério da Educação, o Plano de Metas Compromisso Todos pela Educação, sendo um programa estratégico do PDE, inaugurou um novo regime de colaboração entre os entes federados, sem lhes ferir a autonomia, visando à melhoria dos indicadores educacionais (Plano de Ações Articuladas, 2016).

O relatório do estudo "Educação integral/educação integrada e(m) tempo integral: concepções e práticas na educação brasileira” (Brasil, 2010b) apontou o Pará entre os estados com menores índices (4,2\%) de experiências em jornada escolar ampliada. Segundo o documento, em 2008 as maiores experiências de jornada ampliada escolar do Brasil concentravam-se nas regiões Sudeste, Sul e Nordeste. Sendo que na região Norte, apenas os estados do Amazonas, Pará e Tocantins evidenciaram experiências com jornada escolar ampliada. Assim como na maioria dos estados da federação, a educação básica no estado do Pará “[...] também é marcada pelo abandono e reprovação e tem sua expansão ameaçada pela evasão [...]” (Pará, 2015b, p. 03). Por isso, transformar as condições existenciais dessa realidade educacional representa um desafio para os gestores e toda a sociedade.

Foi nesse contexto que o Governo do Estado do Pará, por meio da Secretaria de Estado de Educação (SEDUC), em cumprimento à política nacional de ampliação da jornada escolar, prevista nos dispositivos legais como a LDBEN n. 9.394/96 e o Plano Nacional de Educação, aderiu aos programas federais: Programa Mais Educação (PME), voltado para o ensino fundamental, e o Programa Ensino Médio Inovador (ProEMI) que sinalizam à ampliação da jornada escolar e propõem a reestruturação curricular, fomentando a diversidade das atividades práticas pedagógicas. Ressalta-se que “[...] estas iniciativas possibilitaram o aprofundamento das reflexões sobre os aspectos 
conceituais e operacionais em direção à perspectiva dos modelos pedagógicos da educação integral" (Pará, 2015b, p. 4).

A implementação da educação integral no Pará vem acontecendo de forma gradativa, paralela ao regime de tempo parcial. Contudo, não descarta a possibilidade de ampliação da oferta da educação integral e do aumento das matrículas dos alunos atendidos em tempo integral através da elaboração de modelos alternativos de oferta de educação integral, da consolidação do currículo e do reordenamento das redes de ensino (Pará, 2015a).

De acordo com os dados do Instituto Nacional de Estudos e Pesquisas Educacionais (INEP), em 2013, o quantitativo de unidades de ensino que ofertavam educação integral no Pará atingia 207 escolas, atendendo aproximadamente 20.000 alunos, representados pelas redes municipal, estadual e privada (Pará, 2015a). A seguir, a tabela 1 apresenta os percentuais de escolas públicas com matrículas em tempo integral no Pará nos anos de 2011 a 2013.

Tabela 1 - Porcentagem de escolas públicas com matrículas em tempo integral no estado do Pará.

\begin{tabular}{clccc}
\hline Nível & Rede & \multicolumn{3}{c}{ Ano } \\
& & $\mathbf{2 0 1 1}$ & $\mathbf{2 0 1 2}$ & $\mathbf{2 0 1 3}$ \\
Educação Infantil & Pública & $2,7 \%$ & $2,4 \%$ & $3,1 \%$ \\
Ensino Fundamental (anos iniciais) & Pública & $4,5 \%$ & $6,0 \%$ & $13,8 \%$ \\
Ensino Fundamental (anos finais) & Pública & $8,5 \%$ & $11,4 \%$ & $23,4 \%$ \\
Ensino Médio & Pública & $6,6 \%$ & $7,8 \%$ & $4,6 \%$ \\
\hline
\end{tabular}

Fonte: Documento Base do Plano Estadual de Educação (Pará, 2015a). Elaborado pela autora (2016).

Constata-se que há uma predominância de escolas em tempo integral nos anos finais do Ensino Fundamental, que pode ter acontecido em virtude de ações decorrentes de programas indutores que se concentram nesse nível de ensino, representado pelo PME, com recursos financeiros destinados para o atendimento de alunos em regime de tempo integral.

Quanto ao quantitativo de matrículas em tempo integral, há uma maior concentração na educação infantil, como evidencia a tabela abaixo: 
Tabela 2 - Porcentagem de matrículas na rede pública em tempo integral no estado do Pará.

\begin{tabular}{clccc}
\hline Nível & Rede & \multicolumn{3}{c}{ Ano } \\
& & $\mathbf{2 0 1 1}$ & $\mathbf{2 0 1 2}$ & $\mathbf{2 0 1 3}$ \\
Educação Infantil (creche) & Pública & $21,6 \%$ & $19,3 \%$ & $21,1 \%$ \\
Educação Infantil (pré-escola) & Pública & $1,5 \%$ & $1,6 \%$ & $1,8 \%$ \\
Ensino Fundamental (anos iniciais) & Pública & $3,7 \%$ & $5,6 \%$ & $10,9 \%$ \\
Ensino Fundamental (anos finais) & Pública & $3,9 \%$ & $5,0 \%$ & $8,5 \%$ \\
Ensino Médio & Pública & $0,5 \%$ & $0,6 \%$ & $0,4 \%$ \\
\hline
\end{tabular}

Fonte: Documento Base do Plano Estadual de Educação (Pará, 2015a).

Elaborado pela autora (2016).

$\mathrm{Na}$ esfera estadual, segundo consulta realizada no portal de serviços da SEDUC (Pará, 2016), existem 13 escolas de tempo integral no Pará, localizadas nos municípios de Ananindeua, Belém, Benevides e Castanhal. A seguir, a tabela 3 apresenta o número de escolas e matrículas de tempo integral na rede estadual de ensino do estado do Pará.

Tabela 3 - Número de escolas e matrículas de tempo integral na rede estadual de ensino do estado do Pará.

\begin{tabular}{ccccccc}
\hline Município & \multicolumn{3}{c}{ No de Escolas } & \multicolumn{3}{c}{ No de matrículas } \\
& $\mathbf{2 0 1 3}$ & $\mathbf{2 0 1 4}$ & $\mathbf{2 0 1 5}$ & $\mathbf{2 0 1 3}$ & $\mathbf{2 0 1 4}$ & $\mathbf{2 0 1 5}$ \\
Ananindeua & 2 & 1 & 1 & 267 & 122 & 127 \\
Belém & 8 & 8 & 10 & 1.664 & 1.570 & 1.941 \\
Benevides & 0 & 0 & 1 & 0 & 0 & 81 \\
Castanhal & 1 & 1 & 1 & 45 & 45 & 59 \\
Total & 11 & 10 & 13 & 1.976 & 1.737 & 2.208 \\
\hline
\end{tabular}

Fonte: SEDUC/Pará (2016) 5 . Elaborado pela autora (2016).

Conforme dados da tabela 3, percebe-se que o maior número de escolas de tempo integral está centrado na capital do estado, compreendendo 10 (dez) instituições em 2015, sendo que nos anos 2013 e 2014 possuía somente 08 (oito) escolas com atendimento integral. Em 2013, o município de Ana-

5 Informações disponíveis em: http://www.seduc.pa.gov.br/portal/escola/consulta_escola/frmConsultaTempoIntegral.php. Acesso em: 28 fev. 2016. 
nindeua contava com duas instituições e nos anos seguintes manteve somente uma. Já o município de Benevides possui uma escola de tempo integral desde 2015, onde atendeu 81 alunos. Castanhal conta com uma escola de tempo integral, mantendo-se nesse quantitativo, porém houve um acréscimo de 31,1\% no seu atendimento, pois em 2015 foram matriculados 59 alunos e no período anterior somente 45 alunos. Constata-se que no período de 2013 a 2015 o quantitativo de escolas de tempo integral do estado paraense evoluiu 18,2\%, elevando também em $11,7 \%$ a taxa de matrícula.

O município de Santarém localiza-se na mesorregião do Baixo Amazonas, na margem direita do Rio Tapajós. É o principal centro socioeconômico do Pará, pois possui um setor de serviços mais desenvolvido e oferece melhor infraestrutura econômica e social. Segundo estimativa do Instituto Brasileiro de Geografia e Estatística de 2013, ocupa uma área de 22.886,624 Km², sendo que $77 \mathrm{Km}^{2}$ estão em perímetro urbano. A população do município de Santarém é de 288.462 habitantes residentes nas zonas rural e urbana da cidade, sendo que 49,46\% são do sexo masculino e 50,54\% do sexo feminino (Santarém, 2015).

De acordo com o Plano Municipal de Educação ${ }^{6}$, Santarém possui um total de 432 instituições públicas de educação básica. Na rede estadual, conta com 35 escolas, destas 34 estão na área urbana e uma no campo. Na rede municipal, existem 397 escolas, das quais 71 estão localizadas no limite urbano e 321 no espaço campestre, sendo 231 escolas na região de rios e 90 na região de planalto (Santarém, 2015). O ensino público da educação básica em Santarém é coordenado pela Secretaria Municipal de Educação e Desporto (SEMED) e pela 5a URE, órgão representante da Secretaria Estadual de Educação, responsável por coordenar o ensino das escolas estaduais dos municípios de Aveiro, Belterra, Mojuí dos Campos e Santarém, onde está sediada. A tabela 4 demonstra o quantitativo de escolas e matrículas de cada um desses municípios.

6 Aprovado pela Lei n. 19.829/2015, de 14 de julho de 2015. 
Tabela 4 - Quantitativo de escola e matrícula por municípios da 5a URE/SEDUC/Pará - Ano: 2015.

\begin{tabular}{cccc}
\hline 5a URE-MUNICÍPIOS & $\begin{array}{c}\text { TOTAL DE } \\
\text { ESCOLAS }\end{array}$ & $\begin{array}{c}\text { TOTAL DE } \\
\text { ANEXOS }\end{array}$ & $\begin{array}{c}\text { TOTAL DE } \\
\text { MATRÍCULAS }\end{array}$ \\
Aveiro & 1 & 0 & $\mathbf{2 0 1 5}$ \\
Belterra & 1 & 0 & 764 \\
Mojuí dos Campos & 1 & 0 & 773 \\
Santarém & 35 & 11 & 600 \\
Total da URE & 38 & 11 & 36.862 \\
\hline
\end{tabular}

Fonte: SEDUC/Pará (2016) 7 . Elaborado pela autora (2016).

Identificamos, conforme descrito na tabela 4, que em 2015 foram matriculados 38.999 alunos nas 38 escolas e nos seus 11 anexos distribuídos nos quatro municípios que integram a $5^{\text {a }}$ URE. Nota-se que a rede estadual de ensino em Santarém atendeu 36.862 alunos nas suas 35 escolas e anexos.

No tocante ao tempo de atendimento das escolas, pode-se inferir que não há registro na SEDUC de escolas de tempo integral em Santarém. As escolas de tempo integral do Pará estão localizadas na sua capital Belém e nos municípios de Ananindeua, Benevides e Castanhal (Pará, 2016). Entretanto, a partir de 2009, o município de Santarém iniciou a ampliação da jornada escolar em algumas escolas estaduais através da realização de atividades complementares no contraturno, em parceria com o Governo Federal, por meio da adesão ao Programa Mais Educação.

De acordo com informações fornecidas pela 5a URE, no ano de 2009 do universo total das escolas estaduais de Santarém apenas 10 (dez) instituições aderiram ao PME, atendendo um total de 4.645 alunos, expandindo-se a partir de 2010 para um total de 26 escolas e um atendimento de 7.015 estudantes. Nesse contexto, importa refletir sobre os resultados do desempenho escolar dos alunos apontados pelo INEP e as metas projetadas para o município de Santarém, demonstrados na tabela 5 a seguir:

7 Informações disponíveis em: http://www.seduc.pa.gov.br/portal/escola/consulta_matricula/ RelatorioMatriculas.php?codigo_ure=5. Acesso em: 29 fev. 2016. 
Tabela 5 - Ideb da rede de ensino estadual do município de Santarém - Resultados e Metas.

\begin{tabular}{|c|c|c|c|c|c|c|c|c|c|c|c|}
\hline \multirow{2}{*}{$\begin{array}{c}\text { Série/ } \\
\text { Ano }\end{array}$} & \multicolumn{4}{|c|}{ Ideb Observado } & \multicolumn{7}{|c|}{ Metas projetadas } \\
\hline & 2009 & 2011 & 2013 & 2015 & 2009 & 2011 & 2013 & 2015 & 2017 & 2019 & 2021 \\
\hline $\begin{array}{c}4^{\mathrm{a}} \\
\text { Série/5o } \\
\text { ano }\end{array}$ & 4.4 & 4.7 & 4.9 & 5.1 & 3.9 & 4.3 & 4.6 & 4.9 & 5.2 & 5.5 & 5.8 \\
\hline $\begin{array}{c}8^{a} \\
\text { Série/9o } \\
\text { ano }\end{array}$ & 3.3 & - & 3.3 & 3.6 & 3.8 & 4.1 & 4.5 & 4.8 & 5.1 & 5.3 & 5.6 \\
\hline
\end{tabular}

Fonte: INEP/MEC $(2016)^{8}$. Elaborado pela autora (2016).

Diante dos resultados apresentados na tabela 5, nota-se que em geral as metas projetadas têm sido alcançadas, especificamente nos anos iniciais do ensino fundamental, mas precisam ser melhoradas nos anos finais, uma vez que seus resultados são preocupantes e contrariam as expectativas previstas para o desenvolvimento econômico e social do Pará nas próximas décadas.

Nesse sentido, a educação integral enquanto uma política pública por meio de experiências de educação em tempo integral, ainda em processo, busca tornar-se um fator de renovação no cenário educacional e contribuir para a qualidade do ensino e aprendizagem. A educação integral reconhece a pessoa como um todo. Mas, para que a escola pública de tempo integral se viabilize como política pública, conforme reivindicado pelo ordenamento jurídico, ela precisa enfrentar alguns condicionamentos conforme aponta Maurício (2009).

O primeiro deles é que a instituição escolar precisa da adesão daqueles que são obrigados por lei a frequentá-la. No entanto, a escola pode se fazer convidativa para que o educando goste e queira estar por mais tempo nesse espaço educativo. $\mathrm{O}$ segundo condicionante é de que a escola se torne um laboratório de soluções, o que pressupõe que o horário integral seja para alunos e professores. Como terceiro condicionante, a escola pública de horário integral tem como pressuposto a aprendizagem e não a reprovação. $\mathrm{O}$ quarto aspecto a ser considerado é que a escola pública de horário integral, sendo uma polí-

8 Os resultados marcados em verde referem-se ao Ideb que atingiu a meta. Informações disponíveis em: http://ideb.inep.gov.br/resultado. Acesso em: 23 out. 2016. 
tica de Estado, seja implantada pelos órgãos estatais diretamente e seja fruto de ação conjunta com instituições da sociedade civil. E, por fim, esse tipo de escola deve ser opcional para o aluno e para o professor. Ambos devem querer passar por essa experiência e devem ser cativados para enfrentar esse desafio.

A autora acrescenta que não há como universalizar a escola de horário integral em curto espaço de tempo, pois " $\mathrm{Na}$ medida em que a escola tenha sucesso, contando com todos os recursos que ela deve ter, a demanda aumenta e a oferta poderá acompanhá-la. Isto atende a mais um requisito: a implantação paulatina dessa escola” (Maurício, 2009, p. 57).

A aprendizagem ocorre ao longo da existência humana por meio da sua relação social, tendo em vista que o homem como um sujeito histórico, através do trabalho, se apropria e transforma a natureza para sua sobrevivência. No entanto, como enfatiza Gonçalves (2006, p. 131), o aprender pressupõe a superação de enigmas e por isso a ampliação e apropriação de conhecimento só é possível "[...] se for estabelecida uma relação entre o particular e o geral, entre o local e o global, entre o que o define como sujeito e o mundo que o rodeia”.

Para Saviani (2013, p. 14), "[...] a escola é uma instituição cujo papel consiste na socialização do saber sistematizado", o que justifica a razão da sua existência como forma de possibilitar o acesso à ciência, ou seja, ao saber elaborado. Assim, cabe à escola formar cidadãos capazes de atuar na sociedade, contribuindo para sua transformação. Observa-se, portanto, a relevância da educação para o desenvolvimento e historicidade do homem. Nesse âmbito, considerando que a formação humana é um processo permanente que acontece durante toda a vida e de diferentes formas, a educação precisa ser integral e cidadã.

Para que a escola cumpra sua função social é preciso ir além da garantia do acesso, como matrícula e permanência. Quando se discute escola em tempo integral, as relações do ambiente escolar devem ser repensadas e reformuladas, o que implica no processo de construção de um tempo e espaços democráticos em que cada segmento possa expressar suas necessidades e dar opiniões sobre a forma de organização desse espaço, que é comum a todos.

Portanto, em sintonia com Gonçalves (2006) entende-se que a ampliação da jornada escolar, ou seja, a implantação de escolas de tempo integral só 
tem sentido se a concepção de educação integral representar uma ampliação de oportunidades e situações que promovam aprendizagens significativas e emancipadoras. Deste modo, como afirma Moll (2012, p. 141), é necessário “[...] construir e perseguir a educação integral como política formativa que busca trabalhar pedagógica, curricular e epistemologicamente de modo pleno e não compensatório". Assim, é importante esclarecer que a escola de tempo integral com jornada de, no mínimo, 7 (sete) horas não significa educação integral. No entanto, admite-se a necessidade de tempo integral para o desenvolvimento de ações educativas que interliguem e promovam a interação com a família e com a sociedade. A construção de uma proposta de educação integral pressupõe novos conteúdos, que não são apenas teóricos, mas conteúdos vivenciais e existenciais que promovam a integração das atividades pedagógicas da sala de aula com as atividades do cotidiano, "[...] relacionados à sustentabilidade ambiental, aos direitos humanos, ao respeito, à valorização das diferenças e à complexidade da relação da escola com a sociedade" (Pegorer, 2014, p. 134).

Desta forma, é indispensável que as instituições de ensino superior se preocupem em rever o currículo dos cursos de formação dos professores, que haja o diálogo permanente entre gestores, professores, estudantes e comunidade, além da reestruturação do currículo, dos espaços educativos e extensão da jornada escolar.

\section{A implementação do programa mais educação nas vozes dos educadores}

A escola deve apresentar condições adequadas para seu funcionamento, sejam físicas ou organizacionais. Nessa perspectiva, Gonçalves (2006) destaca que algumas condições devem existir a priori, ou seja, um corpo docente, salas e mobiliários adequados ao número de alunos, salas de aula, sala-ambiente de leitura, de informática, de ciências, e o caráter de seu funcionamento deve ser uma consequência das relações democráticas vividas no seu interior. No entanto, para o autor, o que permeia e qualifica uma escola de tempo integral é a concepção de educação integral que está como "pano de fundo" para fundamentar sua execução, seja na ampliação da jornada escolar ou na articulação da escola com outros espaços públicos de aprendizagens. 
Assim, para os participantes da pesquisa a educação integral busca o desenvolvimento global do aluno e a sua preparação para a cidadania. Esse pensamento converge ao de Ernica (2006, p. 16), pois “[e]ducar integralmente é formar uma pessoa globalmente, tornando-se apta a participar do mundo no qual vive de modo a realizar e expandir suas necessidades e potencialidades”.

Sobre a concepção de educação integral os educadores entrevistados apresentaram posicionamentos variados e divergentes. Para alguns (AC2, BD1 e BC2) a "extensão do tempo escolar" é imprescindível para se promover uma educação integral, pensamento que se assemelha à compreensão de Coelho (2009) quando afirma que falar sobre educação integral pressupõe pensar em tempo ampliado na escola, ou seja, a educação integral somente é possível com o tempo escolar ampliado.

Ressalta-se que o entrevistado BD1 considera o conceito de educação integral equivalente à escola de tempo integral, ou seja, como tarefa restrita ao espaço escolar. Nesta perspectiva o aumento da jornada escolar é fator determinante para a efetivação desse tipo de educação. Os outros sujeitos (AD1, BC1, BD2, TÉCNICA DA 5a URE) apresentaram um posicionamento que se assemelha às ideias de Gadotti (2009), Libâneo (2015), Paro (2009) e Cavaliere (2007), os quais argumentam que a educação integral pode se desenvolver com ou sem a extensão do tempo escolar.

De fato, o que predomina na visão dos educadores entrevistados é o entendimento de que a educação integral é diferente de educação em tempo integral, embora compartilhem do mesmo objetivo: formar o aluno em suas múltiplas dimensões para o exercício da cidadania. Porém, a ampliação do tempo escolar é compreendida como obrigatória no segundo caso. Portanto, esse posicionamento está aliado às políticas educacionais oficiais e se aproxima da concepção liberal de educação, ou seja, voltada para preparar o aluno para a cidadania.

A falta de consenso entre os educadores entrevistados a respeito do conceito de educação integral nos permite inferir que não há uma concepção única de educação integral que norteia as ações das escolas pesquisadas. Entretanto, eles identificam a educação integral como uma possibilidade de desenvolvimento integral dos educandos. Conforme sustenta Gonçalves (2006), é a con- 
cepção de educação integral que está como pano de fundo para fundamentar sua execução que permeia e qualifica uma escola de tempo integral.

Percebe-se, portanto, que a educação integral não se resume a tempo integral, mas presume-se que o tempo maior de escolarização possibilita maiores oportunidades de aprendizagem. Isso significa que uma política efetiva de educação integral requer uma mudança da própria concepção e do tipo de formação oferecidos, ou seja, não se traduz somente em aumentar o tempo de educação escolar.

A ausência de capacitação para os profissionais da escola e monitores é apontada como uma das dificuldades no desenvolvimento das atividades do PME. A busca por conhecimentos sobre o Programa, principalmente no momento da sua implantação nas escolas, levou os educadores a criarem estratégias (reuniões, pesquisa no site do MEC) para suprir essa necessidade. Portanto, na visão dos entrevistados, a falta de preparação prévia dos profissionais da escola foi um aspecto negativo dessa política educacional. Segundo Gadotti (2009), a implantação do tempo integral nas escolas exige preparo técnico-político e formação, tanto dos pais quanto dos alunos, professores e demais funcionários da escola.

Um ponto positivo destacado pelo entrevistado BD1 foi a parceria entre o coordenador do PME e o gestor como articulador dos estudos sobre o programa, considerando que o documento Programa Mais Educação: Passo a passo (Brasil, 2013) orienta que o diretor escolar deve incentivar a participação, o compartilhamento de decisões e informações com a comunidade escolar, além de promover o debate da educação integral em jornada ampliada.

$\mathrm{O}$ entrevistado $\mathrm{BC} 1$ evidenciou sua preocupação, enquanto coordenador, em compartilhar com os monitores as diretrizes do PME no sentido de conhecerem melhor suas atribuições para que assim pudessem planejar as atividades e lamentou o fato de não terem ocorrido encontros de capacitação no início do Programa. Colares e Bryan (2014, p. 178) destacam que “[...] a formação continuada refere-se às atividades desenvolvidas para o aprimoramento do profissional por meio de cursos diversificados, nos vários níveis e modalidades previstos na estrutura educacional [...]". Assim, é importante 
rever "[...] caminhos para a efetivação de programas formativos qualificados" (Fialho; Sousa; Freire, 2020, p. 18).

Quanto à organização do PME, na Escola $\mathrm{A}$, as atividades ou oficinas do PME aconteciam no contraturno, com duração de 03 (três) horas diárias e eram realizadas pelos monitores, conforme as recomendações do MEC. Tanto na Escola A como na Escola B, os monitores eram acadêmicos de cursos de graduação e pessoas da comunidade que trabalhavam de forma voluntária. Eram selecionados pela própria escola por meio de análise do currículo, conforme relato dos entrevistados.

Constatou-se que os principais desafios para a prática do PME nas Escolas A e B estão relacionados à necessidade de apoio e acompanhamento do Programa de forma institucional, capacitação dos profissionais da educação, carência de conhecimentos sobre o Programa, estabelecimento de parceria com monitores, planejamento financeiro, carência de coordenador e infraestrutura adequada das escolas. É pertinente destacar que a falta de diálogo entre os professores das disciplinas curriculares e monitores não foi considerada dificuldade na visão dos entrevistados, o que demonstra uma postura contraditória, uma vez que raramente aconteciam momentos para o planejamento que possibilitasse a interação entre eles. As dificuldades foram indicadas pelos entrevistados como aspectos negativos decorrentes do PME e ao mesmo tempo desafios para a escola.

De acordo com os entrevistados, a principal contribuição do PME refere-se à melhoria na aprendizagem e no desempenho escolar dos alunos, situação pouco perceptível nos resultados do Ideb. Numa escala menor, apontaram ainda, que a participação dos alunos nas atividades diversificadas proporcionadas pelo programa melhorou as relações interpessoais, reduziu a indisciplina, aumentou a participação dos pais e alunos na escola, tirou os alunos da rua, enfim, contribuiu para a formação dos alunos. Em suma, a implantação do PME nas duas escolas foi uma prática que desafiou os gestores e implicou um trabalho de mobilização da comunidade escolar, e de busca de conhecimentos para a compreensão dessa proposta indutora de educação integral. 
Frente ao panorama das escolas pesquisadas, retratado na percepção dos entrevistados, infere-se que são necessários investimentos na formação continuada e valorização profissional dos atores envolvidos, na infraestrutura das escolas, além da participação efetiva da comunidade na gestão escolar. Nessa perspectiva, o trabalho dinâmico e o compromisso dos gestores escolares com a comunidade interna e externa da escola tornam-se indispensáveis para o enfrentamento desses desafios. Esse esforço deve ser fundamentado por um Projeto Político-Pedagógico (PPP) elaborado coletivamente e de forma consistente, prevendo a integração das atividades do PME ao currículo escolar.

\section{Considerações finais}

Para se pensar numa educação em tempo integral, com vistas ao desenvolvimento integral do educando, que possa contribuir para a melhoria do seu desempenho e a redução das desigualdades educacionais, como propõe o PME - ainda que no aspecto legal - é fundamental que as escolas considerem as variáveis do tempo, espaço e oportunidades de aprendizados. Entretanto, isso pressupõe comprometimento dos gestores, da comunidade escolar, Secretarias de Educação e do Estado nas ações de planejamento, melhorias na estrutura física e humana das escolas, investimentos na formação continuada e valorização dos profissionais da educação.

O PME não deve ser compreendido como se fosse um projeto isolado, cuja responsabilidade do seu êxito fosse somente dos gestores, coordenadores e monitores. Na medida em que ele é incorporado ao PPP da instituição, é preciso que todos os segmentos da escola se envolvam em suas ações educativas. Para tanto, os educadores devem conhecer as diretrizes e os objetivos dessa política, mas, principalmente, assumir o compromisso com a formação integral dos alunos.

O estudo evidenciou que a educação integral é um processo amplo que visa ao desenvolvimento pleno do ser humano, podendo ser realizada com ou sem ampliação do tempo escolar, pois independente disso "[...] tem possibilidade de desenvolver-se quando assume [...] o caráter de progressão educacional em seus múltiplos aspectos incluindo o aspecto do cuidado 
em harmonia com o crescimento, o desenvolvimento e a aprendizagem [...]" (Gomes; Colares, 2018, p. 317).

A partir da análise da prática vivenciada pelas escolas pesquisadas constatou-se que a educação integral, na perspectiva de possibilitar o desenvolvimento integral do educando, compreendendo-o como sujeito de direitos, ainda é uma realidade distante das escolas pesquisadas. A pesquisa revelou, portanto, que otimizar o tempo do aluno na escola, atendendo as suas diversas habilidades, competências e conhecimentos exigidos na contemporaneidade continua sendo uma tarefa desafiadora para as escolas da rede estadual de ensino de Santarém.

A educação integral na perspectiva de formação emancipadora, independente da forma como ela se desenvolve, seja em tempo parcial ou integral, é um compromisso que deve ser assumido pelo Estado, como política destinada a todos, e pelas escolas, agentes e parceiros educativos sustentado por um PPP consistente, elaborado de forma coletiva, o qual requer investimentos na estrutura das escolas, bem como formação e valorização dos educadores. Assim, é necessário discutir e rever os rumos políticos do Brasil quanto ao financiamento da educação pública, bem como intensificar o movimento de resistência e luta dos profissionais de educação, sindicatos de trabalhadores e dos movimentos sociais populares em defesa da escola pública.

\section{Referências}

APRESENTAÇÃO/PAR. Plano de Ações Articuladas. Disponível em: http://www.fnde.gov.br/programas/par/par-apresentacao. Acesso em: 22 de fev. 2016.

ARROYO, Miguel Gonzáles. O direito a tempos-espaços de um justo e digno viver. In: MOLL, Jaqueline (org.). et al. Caminhos da educação integral no Brasil: direitos a outros tempos e espaços educativos. Porto Alegre: Penso, 2012, p. 33-45.

BARDIN, Laurence. Análise de conteúdo. São Paulo: Edições 70, 2011. 
BRASIL. Decreto n. 6.094, de 24 de abril de 2007. Dispõe sobre a implementação do Plano de Metas Compromisso Todos pela Educação. Decreto n. 6.094, de 24 de abril de 2007, Brasília, 2007a. Disponível em: http://www. planalto.gov.br/ccivil_03/_ato2007-2010/2007/Decreto/D6094.htm. Acesso em: 22 de out. 2015.

BRASIL. Decreto n.7.083, de 27 de janeiro de 2010. Dispõe sobre o Programa Mais Educação. Decreto n.7.083, de 27 de janeiro de 2010. Brasília, 2010a. Disponível em: http://www.planalto.gov.br/ccivil_03/_ato2007-2010/2010/ decreto/d7083.htm. Acesso em: 10 de dez. 2015.

BRASIL. Ministério da Educação. Secretaria de Educação Básica. Programa Mais Educação: Passo a passo. Brasília, 2013.

BRASIL. Ministério de Estado da Educação. Conferência Nacional de Educação (CONAE). Brasília, Ministério da Educação, 2010b. Disponível em: http://conae.mec.gov.br/images/stories/pdf/pdf/documetos/documento_final_sl.pdf. Acesso em: 01 de fev. 2016.

CAVALIERE, Ana Maria. Tempo de escola e qualidade na educação pública. Educação e Sociedade, Campinas, vol. 28, n. 100 - Especial, p. 1015-1035, out. 2007. Disponível em: https://www.scielo.br/pdf/es/v28n100/a1828100. pdf. Acesso em: 10 de jun. 2016.

COELHO, Lígia Martha Coimbra da Costa. História (s) da educação integral. Em Aberto, v. 22, n. 80, p. 83-96, abr. 2009. Disponível em: http://www.oei. es/pdf2/educacao_integral_tempo_integral.pdf. Acesso em: 10 de out. 2015.

COLARES, Maria Lília Imbiriba Sousa; BRYAN, Newton Antonio Paciulli. Formação continuada e gestão democrática: desafios para gestores do interior da Amazônia. ETD-Educ. temát. digit., Campinas, SP, v. 16, n. 1, p. 174-190, jan./abr. 2014. ISSN 1676-2592. Disponível em: http://www.fae.unicamp.br/ revista/index.php/etd/article/view/5550. Acesso em: 14 de mar. 2021. 
ERNICA, Maurício. Percurso da educação no Brasil. In: Seminário Nacional Tecendo Redes para a Educação Integral. São Paulo: Cenpec/Ação Educativa, 2006. Disponível em: https://educacaoeparticipacao.org.br/wp-content/ uploads/2015/06/seminario_tecendo_redes.pdf. Acesso em: 19 de set. 2016.

FIALHO, L. M. F.; SOUSA, F. G. A. de; FREIRE, V. C. C. Formação continuada de professores: o que se publica no Norte e Nordeste?. Revista Exitus, [S. l.], v. 10, n. 1, p. e020038, 2020. DOI: 10.24065/2237-9460.2020v10n 0ID1286. Disponível em: http://www.ufopa.edu.br/portaldeperiodicos/index. php/revistaexitus/article/view/1286. Acesso em: 14 de mar. 2021.

GADOTTI, Moacir. Educação integral no Brasil: inovações em processo. São Paulo: Editora e Livraria Instituto Paulo Freire, 2009.

GOMES, T. C.; COLARES, M. L. I. S. A política de educação integral em tempo integral: a perspectiva dos professore. Práxis Educacional, [S. l.], v. 15, n. 31, p. 313-332, 2019. DOI: 10.22481/praxis.v15i31.4675. Disponível em: https://periodicos2.uesb.br/index.php/praxis/article/view/4675. Acesso em: 14 de mar. 2021.

GONÇALVES, Antônio Sérgio. Reflexões sobre educação integral e escola de tempo integral. Cadernos Cenpec, São Paulo, v. 1, n. 2, 2006, p. 129-135. Disponível em: http://cadernos.cenpec.org.br/cadernos/index.php/cadernos/ article/view/136/168. Acesso em: 13 de out. 2015.

LIBÂNEO, José Carlos. Organização e gestão da escola: teoria e prática. 6 . ed. São Paulo: Heccus Editora, 2015.

MAURÍCIO, Lúcia Velloso. Políticas públicas, tempo, escola. In: COELHO, Lígia Martha Coimbra da Costa (org.). Educação integral em tempo integral: estudos e experiências em processo. Petrópolis, RJ: DP et Alii; Rio de Janeiro: FAPERJ, 2009, p. 53-68. 
MOLL, Jaqueline. A agenda da educação integral: Compromissos para sua consolidação como política pública. In: MOLL, Jaqueline et al. Caminhos da educação integral no Brasil: direitos a outros tempos e espaços educativos. Porto Alegre: Penso, 2012, p. 129-146.

PARÁ. Governo do Estado do Pará. Secretaria de Estado de Educação. Secretaria Adjunta de Ensino Fundamental. Documento Base do Plano Estadual de Educação. Belém-Pará, 2015. Disponível em: http://www.seduc.pa.gov.br/ site/seduc/modal?ptg=5019. Acesso em: 10 de dez. 2015a.

PARÁ. Governo do Estado do Pará. Secretaria de Estado de Educação. Secretaria Adjunta de Ensino. Plano de Educação Integral da Educação Básica. Belém-Pará, 2015b.

PARÁ. Secretaria de Estado de Educação. Consulta das Matrículas das Escolas de Santarém. Belém-Pará, 2016. Disponível em: http://www.seduc. pa.gov.br/portal/escola/consulta_matricula/RelatorioMatriculas.php?codigo_ ure=5\&codigo_municipio=44997. Acesso em: 10 Ago. 2016 .

PARO, Vitor Henrique. Educação integral em tempo integral: uma concepção de educação para a modernidade. In: COELHO, Lígia Martha Coimbra da Costa (org.). Educação integral em tempo integral: estudos e experiências em processo. Petrópolis, RJ: DP et Alii; Rio de Janeiro: FAPERJ, 2009, p. 13-20.

PEGORER, Valter. Educação integral: um sonho possível e de realização necessária. São Paulo: Textonovo, 2014.

PPP-ESCOLA A. Projeto Político-Pedagógico da Escola A, 2014.

PPP-ESCOLA B. Projeto Político-Pedagógico da Escola B, 2010.

PRESTAÇÃO DE CONTAS DO PME DA ESCOLA A 2009-2015. Plano de Aplicação de recursos do Programa Mais Educação. 
SANTARÉM. Prefeitura Municipal de Santarém. Secretaria Municipal de Educação. Lei n. 19.829/2015, de 14 de julho de 2015. Plano Municipal de Educação 2015-2025. Santarém-Pará, 2015.

SAVIANI, Dermeval. Pedagogia Histórico-Crítica: primeiras aproximações. 11. ed. Campinas, SP: Autores Associados, 2013.

SEDUC/PARÁ. Governo do Estado do Pará. Secretaria de Estado de Educação. Consulta das matrículas nas escolas de Santarém. Disponível em: http:// www.seduc.pa.gov.br/portal/escola/consulta_matricula/RelatorioMatriculas. php?codigo_ure=5\&codigo_municipio=44997. Acesso em: 17 de set. 2016. 


\section{UM ESTUDO SOBRE EVASÃO NOS CURSOS DE LI- CENCIATURA DO CENTRO DE EDUCAÇÃO, LETRAS E ARTES DA UFAC}

Mark Clark Assen de Carvalho

Gerson da Silva Januário

Adão Rogério Xavier Silva

\section{Introdução}

No Brasil, no tempo presente, apesar da relativa ampliação da educação superior, a simples credencial do acesso à universidade, seja na esfera pública ou privada, configura-se apenas como um elemento primário para a realização das expectativas de grande parte dos ingressantes, condição essa que abre espaço para ressaltar que ainda continuam prementes a necessidade de formulação e a ampliação das políticas de manutenção das condições que possam favorecer a permanência.

Vale lembrar, ainda, de outro aspecto fundamental que compõe esse constructo, qual seja, a permanência, visto que "[...] são tão poucos aqueles que chegam ao ensino superior, entre 9,0\% e 12\% da população jovem (18 a 24 anos) que não podemos permitir as desistências ou os abandonos"(Andriola, 2009, p. 345).

Acerca dessas considerações preliminares, Giraffa (2016, p. 2) discorre que "[...] à medida que o acesso à Educação Superior aumenta, crescem também os problemas relacionados a evasão e a permanência dos estudantes nas instituições de ensino superior”. Entretanto, para os poucos que alcançam o sonho de entrar em uma universidade pública, a realidade acaba por ser interrompida, forçando-os a abandonar o curso por diversos motivos e causas que nem sempre são reconhecidos.

Diante do exposto é que se reforça, portanto, a relevância, a pertinência e a necessidade de empreender uma análise ambientada no contexto institucional da Universidade Federal do Acre (Ufac) sobre a temática da evasão escolar em cursos de graduação, considerando praticamente a inexistência de 
estudos focalizados nessa realidade e a forte incidência das taxas de evasão nos indicadores de desempenho institucional.

Todavia, dados os limites deste estudo, bem como a complexidade que seria efetivar uma análise face a todos os seis Centros Acadêmicos do Campus Rio Branco e os 02 Centros do Campus Floresta, que ofertam 50 cursos de graduação, restringiu-se a análise aos cursos vinculados apenas ao Centro de Educação, Letras e Arte (Cela), agregador dos seguintes cursos de graduação: Pedagogia, Artes Cênicas, Música, Letras Português, Letras Inglês, Letras Espanhol, Letras Francês e Letras Libras.

O estudo se configurou a partir de uma abordagem qualitativa, entrecruzando-se referências da pesquisa bibliográfica com revisão da literatura, análise documental e aplicação de um questionário através do formulário online no Google Drive, enviado eletronicamente ao diretor do Centro de Educação, Letras e Artes (Cela) e aos coordenadores(as) dos cursos.

Nesse sentido, o trabalho segue a seguinte estrutura: a princípio, são tecidas considerações breves sobre a evasão na educação superior, enxertadas no texto como referência para possibilitar uma compreensão geral sobre como está situada a discussão da temática na literatura e em alguns documentos legais da educação superior brasileira. $\mathrm{Na}$ sequência, constam as análises qualitativas dos dados e achados da pesquisa, resultantes dos exames documentais e das respostas dadas ao questionário, seguidas das considerações finais, momento em que se apresentam alguns elementos de reflexão e problematização acerca da temática e da situação identificada juntos aos cursos investigados.

\section{Breves considerações sobre a evasão no ensino superior}

No Brasil, um fato relevante referente aos estudos sobre evasão no ensino superior remonta ao ano de 1995, quando o governo federal realizou o Seminário sobre evasão nas Universidades Brasileiras, no início da gestão do então Ministro da Educação, Paulo Renato de Souza. Como resultado do referido seminário, foi criada a "Comissão Especial para o Estudo da Evasão", sob 
a coordenação da Secretaria de Educação Superior/Ministério da Educação e do Desporto (SESu/MEC, 1996).

De acordo com Adachi (2009, p. 24), “[...] a primeira preocupação da Comissão foi exatamente, posicionar-se face à pergunta: De qual evasão estamos falando? Evasão de curso? De instituição ou do ensino superior?”. Para responder a essas questões, nas primeiras etapas, a comissão definiu como principais objetivos os seguintes:

1. Aclarar o conceito de evasão, considerando suas dimensões concretas: evasão de curso, evasão da instituição e evasão do sistema de ensino superior;

2. Definir e aplicar metodologia homogeneizadora de coleta e tratamento de dados;

3. Identificar as taxas de diplomação, retenção e evasão dos cursos de graduação das IESP do país;

4. Apontar causas internas e externas da evasão, considerando as peculiaridades dos cursos e das regiões do país;

5. Definir estratégias de ação voltadas à redução dos índices de evasão nas universidades públicas brasileiras. (SESu/MEC, 1996, grifos dos autores).

Assim, tem-se que a comissão, “[...] mesmo reconhecendo as limitações possíveis desta opção", adotou o seguinte conceito de evasão:

1. Evasão de curso: quando o estudante desliga-se do curso superior em situações diversas tais como: abandono (deixa de matricular-se), desistência (oficial), transferência ou "reopção" (mudança de curso), exclusão por norma institucional;

2. Evasão da instituição: quando o estudante desliga-se da instituição na qual está matriculado;

3. Evasão do sistema: quanto o estudante abandona de forma definitiva ou temporária o ensino superior (Brasil, 1996, p.15, grifos dos autores).

Com os conceitos definidos, a comissão buscou estabelecer os "parâmetros metodológicos" que permitissem, após a coleta das informações nas universidades participantes e as diretrizes metodológicas visando "garantir a exatidão 
e comparabilidade dos resultados", utilizando-se das experiências de outras Instituições de Ensino Superior (IES) brasileiras.

Amparada nesse pressuposto, a Comissão Especial, entendeu ser fundamental incluir como objeto do estudo não apenas a evasão, mas igualmente as taxas de diplomação e de retenção dos alunos dos diferentes cursos analisados. Tal inclusão permitiria estabelecer com maior clareza a relação entre o "dever ser" e os dados da realidade vivida, hoje, nas universidades públicas brasileiras. Permitiria, por exemplo, localizar prováveis "ilhas de sucesso" opostas a situações extremamente problemáticas em algumas áreas, como já têm sido demonstrados em outros estudos do mesmo gênero [...] (Brasil, 1996, p. 22).

Ao reconhecer a complexidade e a universalização do tema da evasão nas instituições de ensino superior, a Comissão Especial apresentou resultados de estudos realizados em alguns países, os quais se apresentaram mais avançados em relação ao conhecimento dos dados sobre evasão em termos de objeto de estudos e análises. São citados países como Espanha, Finlândia, Argentina, Áustria, França e Estados Unidos, sendo relatado que:

Nos EUA, por exemplo, [...], 'as taxas de evasão estão em torno de 50\% e esta porcentagem é constante nos últimos trinta anos'; a mesma constância verifica-se na França onde as taxas, em 1980, eram de 60 a $70 \%$ em algumas Universidades. Já na Áustria, o estudo aponta para um índice de 43\%, sendo que apenas $13 \%$ dos estudantes concluem seus cursos nos prazos previstos [...] (Brasil, 1996, p. 23).

Verifica-se que o conceito de evasão, de acordo com posição assumida pela Comissão Especial, também se constituiu objeto de divergência entre estudiosos e pesquisadores da temática. Nessa direção, o grupo de trabalho apresentou a perspectiva de Bueno (1993), a qual se encarrega de estabelecer uma diferenciação entre "evasão" como uma postura ativa do aluno, enquanto “exclusão" se refere à postura da escola por não conseguir direcionar de maneira eficiente o aproveitamento do estudante. 
Por sua vez, Ristoff (1995) trata da diferença entre "evasão" e "mobilidade". Em perspectiva, pode-se dizer que a primeira posição se refere ao abandono dos estudos, enquanto a segunda corresponde ao fenômeno de migração do aluno para outro curso. Ristoff (1995) esclarece que:

Parcela significativa do que chamamos evasão, no entanto, não é exclusão, mas mobilidade, não é fuga, não é desperdício, mas investimento, não é fracasso - nem do aluno nem do professor, nem do curso ou da Instituição - mas tentativa de buscar o sucesso ou a felicidade, aproveitando as revelações que o processo natural de crescimento do indivíduo faz sobre suas reais potencialidades (Ristoff, 1995, p. 125).

Fritsch (2015, p. 2) inclui algumas das causas ou efeitos da evasão diferenciando-a de outras situações estudantis:

É um fenômeno complexo, associado com a não concretização de expectativas e reflexo de múltiplas causas que precisam ser compreendidas no contexto socioeconômico, político e cultural, no sistema educacional e nas instituições de ensino. Caracteriza-se por ser um processo de exclusão determinado por fatores e variáveis internas e externas às instituições de ensino.

Dessas considerações, explicita-se certa complexidade do tema, além das interpretações divergentes entre autores que propugnam pela necessidade de racionalizar de maneira objetiva em relação aos conceitos, frente às metodologias a serem aplicadas, para responder às seguintes questões: "de qual evasão estamos falando: evasão de curso? Evasão da instituição? Ou evasão do próprio sistema?” Para responder tais questões, a Comissão Especial (Brasil, 1996, p. 25) definiu como seu objeto de investigação a evasão dos cursos de graduação, considerada, para efeito do estudo, como a saída definitiva do aluno de seu curso de origem, sem concluí-lo. Na sequência, partiu, então, para a definição da metodologia e dos procedimentos, a fim estabelecer a padronização para os dados que seriam analisados. A metodologia utilizada pela comissão foi "definida como de fluxo ou de acompanhamento de estudantes". 
De acordo com a Comissão Especial (Brasil, 1996, p. 28), foram adotados os seguintes procedimentos:

Acompanhar os alunos ingressantes em determinado curso, em ano ou semestre específicos, até o prazo máximo de integralização curricular do referido curso, de acordo com prazos estipulados pelo extinto Conselho Federal de Educação ou, na ausência deles, naqueles estabelecidos por analogia pela Comissão [...]; Utilizar as gerações completas dos cursos estudados, cujo prazo máximo de integralização curricular houvesse expirado nos semestres 92/2, 93/1, 93/2, 94/1 e 94/2 (Brasil, 1996, p. 28).

A Comissão Especial reconheceu que, devido à natureza e à complexidade que envolveu o estudo para unificar a metodologia, seu papel foi alcançado, uma vez que tal estudo:

Contribui para melhor conhecimento e diagnóstico das IESP; Permite conduzir, de maneira mais objetiva e menos intuitiva, os processos de troca de experiências educacionais; Favorece a avaliação objetiva dos resultados das universidades, unificando minimamente conceitos básicos; Contribui para a melhoria da administração e funcionamento dos processos micro e macro administrativos (Brasil, 1996, p. 31).

Em continuidade à análise da temática, verificou-se que o professor norte americano da Syracuse University of Sociology, Vincent Tinto, é citado, basicamente, nos principais estudos sobre evasão no ensino superior. Tinto desenvolveu, em 1975, um modelo teórico denominado Teoria de Integração do Aluno, para o estudo do fenômeno da permanência e da evasão em cursos de graduação, baseando sua fundamentação teórica na concepção de Durkheim sobre o suicídio e na ideia de custo-benefício, oriunda da economia da educação.

No estudo, o autor destaca a importância da integração acadêmica, estabelecida através de compromissos pessoais, sociais e acadêmicos, como elementos instauradores de um forte vínculo do estudante com a instituição. A sua relevância pode ser aferida pelo fato de ser bastante utilizado em universidades norte-americanas assim "como em outros países tais como México, Austrália e Reino Unido”(Andriola, 2009, p. 343). 
Andriola (2009), ao analisar o modelo proposto por Tinto (1975), afirma que "o aluno chega à universidade com intenções, objetivos e compromissos institucionais pré-definidos, que variam em função das características demográficas supramencionadas". Com o passar do tempo dentro do ambiente acadêmico, o aluno é influenciado pelas interações sociais que vai experimentando na instituição, "o que o permite, assim, redefinir suas intenções e seus compromissos, o que, em última instância, leva-o a persistir ou a evadir-se" (Andriola, 2009, p. 3).

Quanto ao modelo teórico desenvolvido por Tinto, Siqueira (2017) também evidencia que:

O modelo supõe que a persistência é função do compromisso do estudante para concluir o curso, do comprometimento do estudante com obrigações externas ao ambiente acadêmico, da formação escolar anterior, da integração acadêmica (intelectual) e da integração social do aluno (pessoal), as duas últimas são essenciais para a persistência e diferenças pessoais (demográficas) que não são menos importantes na determinação da evasão, esse modelo tem sido aplicado para estudar evasão e persistência em cursos de graduação. (Siqueira, 2017, p. 52).

Vale ressaltar que, além da Teoria de Integração do Aluno desenvolvida por Tinto (1975), há outras teorias que podem ser citadas nesta pesquisa, tais como: o Modelo do processo de abandono Sociológico, desenvolvida por Spady (1970); a Teoria do Desgaste do Estudante Não-Tradicional, desenvolvida por Bean e Metzner (1985); a teoria do Modelo de Desgaste Pascarella (1980); a Teoria do Envolvimento do Estudante de Astin (1985) e o Modelo de Desgaste de Estudantes Adultos, formulado por MacKinnon-Slaney (1991).

\section{A evasão nos cursos de Licenciatura do Centro de Educação, Letras e Artes da Ufac: o que dizem os(as) coordenadores(as) de curso}

Nesta parte do estudo, são apresentados e analisados os resultados dos dados coletados e as informações extraídas do questionário aplicado aos coordenadores(as) de cursos. Basicamente, utilizou-se o software de planilhas 
eletrônicas Microsoft Excel como ferramenta para manusear e sistematizar o grande volume de dados obtidos nas diferentes fontes de pesquisa: Núcleo de Registro e Controle Acadêmico (Nurca/Ufac), Instituto Nacional de Estudos e Pesquisas Educacionais Anísio Teixeira (Inep), Instituto Brasileiro de Geografia e Estatística (IBGE), dentre outras.

Destacam-se, inicialmente, os dados consolidados dos cursos do Centro de Educação, Letras e Artes (Cela), uma espécie de panorama geral do período pesquisado. $\mathrm{Na}$ sequência, apresentam-se os resultados obtidos a partir de um questionário aplicado pelo formulário online no Google drive, enviado eletronicamente ao diretor do Cela e aos(as) coordenadores(as) dos cursos de licenciatura em Artes Cênicas, Música, Letras Português, Letras Inglês, Letras Espanhol, Letras Francês e Letras Libras. O formulário foi enviado a nove sujeitos, sendo que, destes, apenas a coordenação de Curso de Letras Francês não deu retorno.

Em um primeiro momento, as respostas e suas respectivas análises são apresentadas sob forma de gráficos e tabelas relacionadas, visando identificar o entendimento dos sujeitos acerca dos motivos que levam à produção dos índices de evasão nos cursos. Na sequência, são tratados, de forma específica, os dados de evasão em cada curso pesquisado para, depois, apresentar a análise dos resultados, na tentativa de buscar compreender o cenário estabelecido. Ressalta-se que são apresentadas as percepções dos(as) coordenadores(as) sobre a questão da evasão no curso e quais são, em suas visões, as ações que poderiam ser implementadas para contribuir com a redução do quadro de evasão encontrado.

A Tabela 1 demonstra que, entre os anos de 2010 e 2014, 1.785 (mil setecentos e oitenta e cinco) alunos ingressaram nos cursos ofertados pelo Cela na Ufac. Desse universo, constatou-se que apenas 33,9\% (605 alunos) foram diplomados; 53,1\% (947 alunos) perderam o vínculo com a universidade, seja por desistência, jubilamento, etc., enquanto 13,1\% (235 alunos) permaneceram na IES com registros de matrícula. 
Tabela 1 - Dados consolidados de todos os cursos do Cela: ingressantes, diplomados, evadidos e retidos $(2010-2014)$.

\begin{tabular}{|c|c|c|c|c|c|c|c|}
\hline CURSO & ALUNOS & DIPLOMADOS & EVADIDOS & RETIDOS & DIPLOMADOS & EVADIDOS & RETIDOS \\
\hline Licenciatura em Artes Cênicas: Teatro & 198 & 68 & 108 & 22 & $34,3 \%$ & $54,5 \%$ & $11,1 \%$ \\
\hline Licenciatura em Letras Espanhol & 277 & 96 & 110 & 71 & $34,7 \%$ & $39,7 \%$ & $25,6 \%$ \\
\hline Licenciatura em Letras Francês & 259 & 44 & 185 & 30 & $17,0 \%$ & $71,4 \%$ & $11,6 \%$ \\
\hline Licenciatura em Letras Inglês & 265 & 66 & 168 & 31 & $24,9 \%$ & $63,4 \%$ & $11,7 \%$ \\
\hline Licenciatura em Letras Libras & 49 & 20 & 22 & 7 & $40,8 \%$ & $44,9 \%$ & $14,3 \%$ \\
\hline Licenciatura em Letras Língua Portuguesa & 265 & 134 & 112 & 19 & $50,6 \%$ & $42,3 \%$ & $7,2 \%$ \\
\hline Licenciatura em Música & 203 & 42 & 121 & 40 & $20,7 \%$ & $59,6 \%$ & $19,7 \%$ \\
\hline Licenciatura em Pedagogia & 269 & 135 & 121 & 13 & $50,2 \%$ & $45,0 \%$ & $4,8 \%$ \\
\hline Total Geral & 1785 & 605 & 947 & 233 & $33,9 \%$ & $53,1 \%$ & $13,1 \%$ \\
\hline
\end{tabular}

Fonte: Elaborado pelos autores a partir dos dados do Nurca/Ufac.

Destaca-se que os cursos que tiveram os maiores índices de alunos diplomados no período analisado foram Pedagogia (50,2\%), Letras Português (50,6\%) e Letras Libras (40,8\%). Por outro lado, os cursos com maiores índices de evasão foram: Letras Francês (71,4\%); Letras Inglês (63,4\%) e Música (59,6\%).

No estudo ora realizado, decidiu-se manter esse curso no intuito de enriquecer a pesquisa, pois, como pode ser visto na Tabela 01, embora se trate de curso novo, ele já apresenta índices de evasão relativamente elevados comparativamente aos demais cursos que compõem a análise.

O Gráfico 01 apresenta o comportamento dos alunos referente ao ingresso, diplomação e evasão, além daqueles que permaneceram retidos na IES. Vale ressaltar que, para os dados apresentados, não se fez distinção entre o aluno que se diplomou dentro do prazo mínimo (04 anos) e o que se diplomou no prazo máximo (07 anos). 
Gráfico 1 - Dados consolidados de todos os cursos do Cela relacionando ingressantes, diplomados, evadidos e retidos (2010 - 2014).

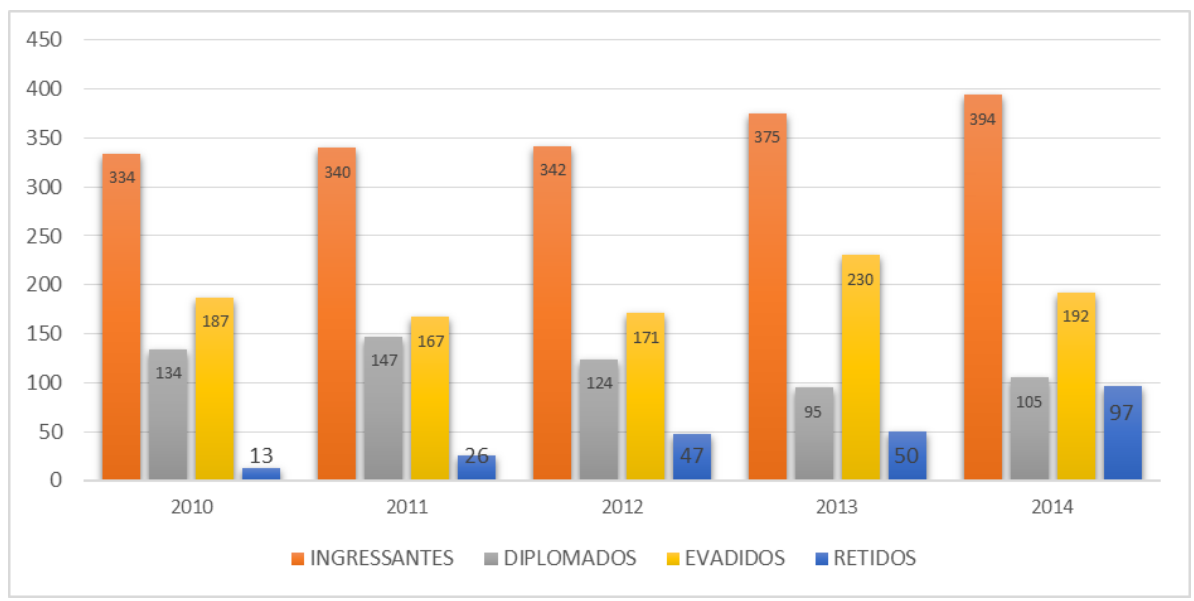

Fonte: Elaborado pelos autores a partir dos dados Nurca/Ufac.

Pode-se verificar, ainda, o aumento no número de alunos retidos no período investigado. A ocorrência desse fato se dá, dentre outros motivos, por conta dos prazos para conclusão do curso. Esse número costuma ser menor nos primeiros anos da pesquisa, porque muitos alunos acabam perdendo os prazos de conclusão e são considerados “jubilados”, mudando o status para "evadido".

No Gráfico 2, por exemplo, verifica-se uma oscilação com tendência de diminuição no número de diplomados ao longo dos anos: em 2010, apenas 40,1\% (134 alunos); em 2012, 36,3\% (124 alunos); em 2013, 25,3\% (95 alunos) e, em 2014 26,5\% (105 alunos); exceção apenas no ano de 2011, com 43,2\% (147 alunos), até então, o melhor resultado na série. 
Gráfico 2 - Dados consolidados de todos os cursos do Cela relacionando ingressantes, diplomados, evadidos e retidos (2010 - 2014).

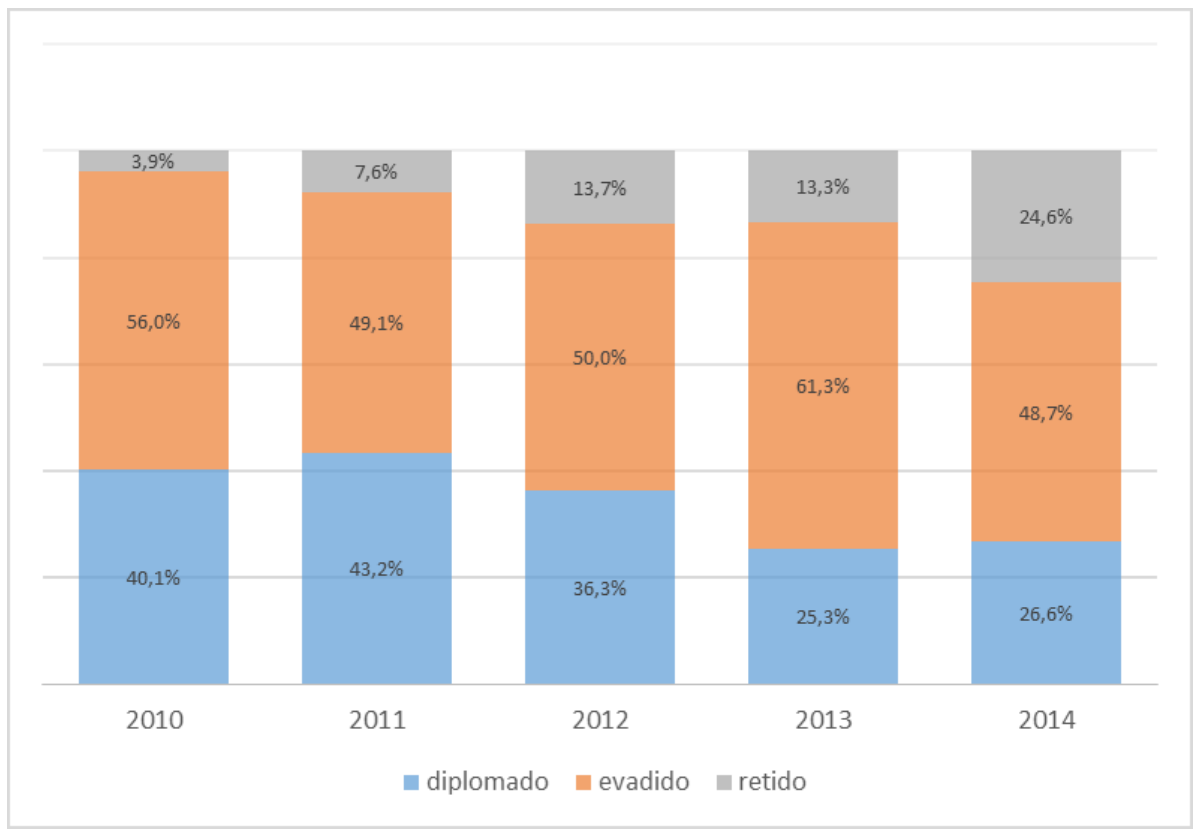

Fonte: Elaborado pelos autores a partir dos dados Nurca/Ufac.

Quanto à situação dos alunos evadidos, os números apresentam uma certa estabilidade, com exceção do ano de 2013, quando o número de alunos evadidos chegou a 61,3\%, contra a média do período, que ficou na faixa de 50,0\%.

Em um primeiro momento, reputa-se como fato bastante preocupante verificar que os percentuais de evasão superam, na maioria dos cursos, o percentual de diplomados e, em casos mais extremos, como Letras Francês e Letras Inglês, as taxas de evasão chegaram a 71,4\% e 63,4\%, respectivamente. Cabe, aqui, questionar se a Ufac tem, de fato, se debruçado na análise desses indicadores. Em caso positivo, quais são as medidas adotadas visando à redução dos índices de evasão?

Ressalta-se que o alto índice de evasão não se configura em caso isolado, uma vez que a média geral de evasão nos cursos pesquisados fica em torno de 53,1\% (Gráfico 03). Na esteira dessa observação, vale destacar, ainda, que, pelos números apresentados, apenas a metade dos alunos ingressantes nos cursos 
do Cela conseguem sair diplomados dentro do prazo mínimo de duração do curso, aspecto que contribui para que se possa inferir que determinado contingente destes alunos pode, eventualmente, vir a concluir o curso dentro do prazo máximo admitido pela Ufac, que é de sete anos.

Gráfico 3 - Dados consolidados de todos os cursos do Cela relacionando ingressantes, diplomados, evadidos e retidos (2010 - 2014).

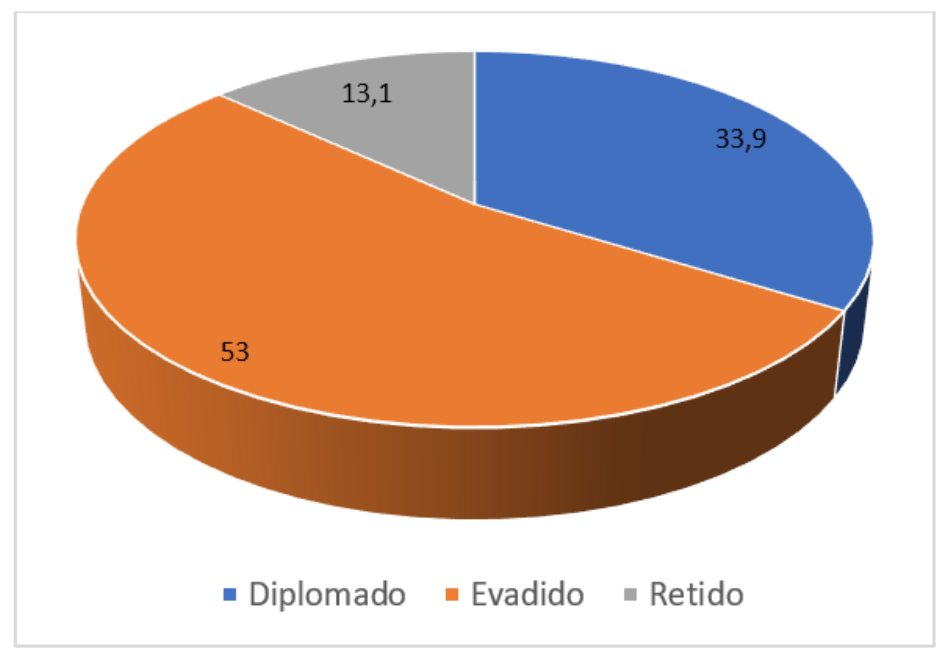

Fonte: Elaborado pelos autores a partir dos dados Nurca/Ufac.

A partir desse momento, tenta-se permear análise quantitativa com análise qualitativa dos dados, ou seja, pontuadas as informações gerais dos cursos, serão apresentadas, também, as percepções dos sujeitos da pesquisa em relação à evasão nos cursos do Cela. Uma questão nuclear se destinava saber sobre o conhecimento dos índices de evasão nos cursos, cujas respostas foram sistematizadas no gráfico a seguir. 
Gráfico 4 - Referente a informação sobre a questão da evasão nos cursos de graduação do Cela?

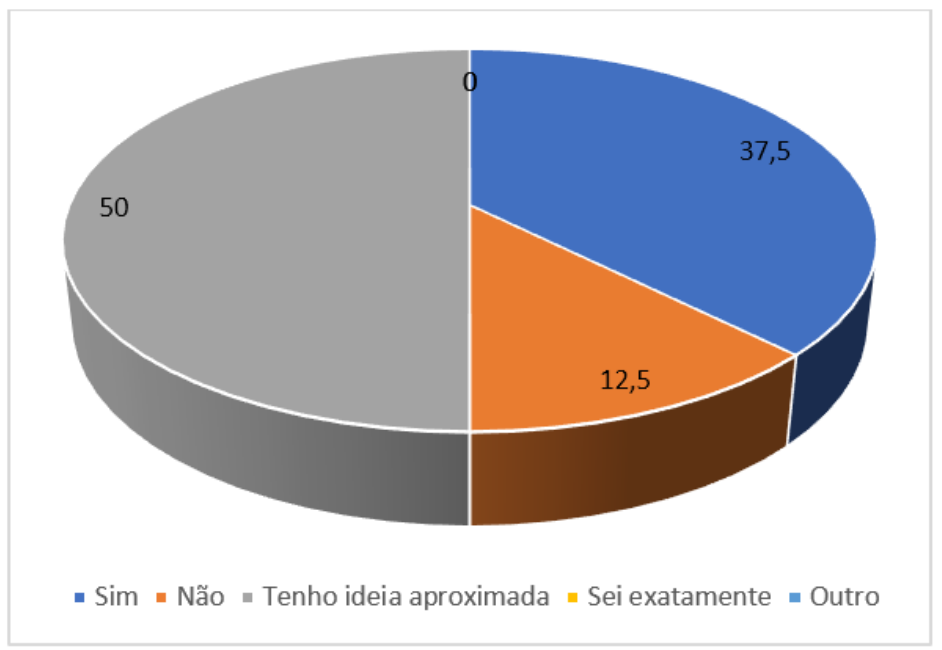

Fonte: Elaborado pelos autores a partir dos dados obtidos no questionário aplicado.

Conforme exposto acima, 50,0\% dos respondentes disseram ter uma ideia aproximada a respeito dos índices de evasão; 37,5\% disseram não ter informações sobre e $12,5 \%$ pontuaram que não tinham nenhuma informação sobre a questão da evasão nos cursos do Cela. Por certo, esse desconhecimento total ou parcial a respeito da evasão pode, de alguma forma, servir para explicar, como veremos mais à frente, o fato de existirem poucas ações específicas nos cursos para o enfrentamento desse grave problema de abandono.

Perguntou-se, ainda, quais são os principais fatores que levam um(a) aluno(a) a evadir-se do curso. Foram oferecidas as seguintes opções: problemas pessoais (desemprego, saúde, família, relacionamentos amorosos); problemas na formação na educação básica deficitária (dificuldades de escrita, leitura e interpretação de textos); desvalorização da profissão docente; preferência por outros cursos de graduação/profissões; precariedade das condições físicas do curso ou inadequação curricular; desconhecimento prévio do curso/decepção com o curso; não concretização das expectativas individuais dos alunos; repetências continuadas nas disciplinas; incompatibilidade entre horários de trabalho e de estudo. O gráfico apresentado, a seguir, serve para ilustrar, em termos percentuais, os resultados obtidos. 
Gráfico 5 - Referente aos fatores que levam o(a) aluno(a) a evadir-se do curso.

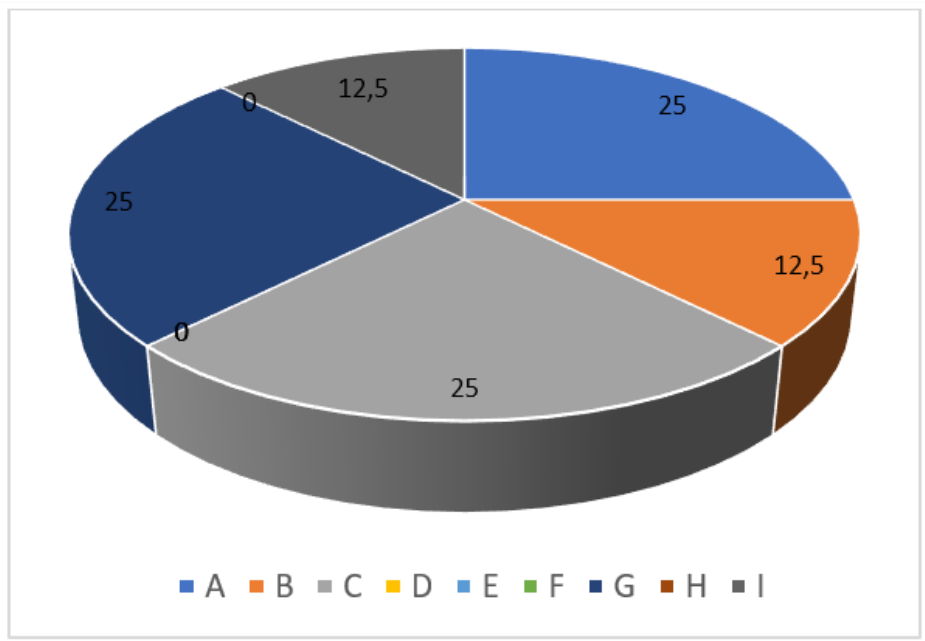

Fonte: Elaborado pelos autores a partir dos dados obtidos no questionário.

As opções apontadas como mais relevantes para o abandono do curso foram as seguintes: $(25,0 \%)$ problemas pessoais (desemprego, saúde, família, relacionamentos amorosos); $(25,0 \%)$ não concretização das expectativas individuais dos alunos; (25,0\%) desvalorização da profissão docente; (12,5\%) problemas na formação na educação básica deficitária (dificuldades de escrita, leitura e interpretação de textos); (12,5\%) incompatibilidade entre horários de trabalho e de estudo. Pode-se ressaltar que as opções escolhidas como predominantes são convergentes com aquilo que se apresenta nas análises nacionais, tal como indicam os estudos de Campos (2018), Pinto (2017), Vitelli e Fritsch (2016).

Como se pode ver, os respondentes tendem a indicar, em termos de prioridades, diferentes causas para a produção da evasão, o que, potencialmente, revela que essas determinações são do conhecimento das pessoas responsáveis por tomada de decisão na instituição.

Contudo, ousa-se ressaltar que o diagnóstico objetivo de questões relativas ao tema não é tratado de maneira específica como questão que requeira da gestão do curso e das instâncias diretamente relacionadas a ela a tomada de medidas que possam servir como dispositivo de compreensão e enfrentamento da problemática no curso. Essa questão se reveste de maior gravidade, ainda, 
quando a situação encontrada na pesquisa dá conta de evidenciar que se tem curso com taxas de evasão em torno de 71,4\% e que, no geral, a evasão nos cursos do Cela alcança uma média de 53,1\%, conforme identificado na Tabela 1.

Ao se questionar os sujeitos sobre quais ações poderiam contribuir para diminuir ou evitar a evasão na Ufac, foram oferecidas as seguintes opções: concessão de bolsa/ajuda financeira; casa de apoio para os estudantes; programa de inserção dos acadêmicos no mercado de trabalho; diagnóstico das dificuldades dos alunos; estabelecimento de contatos com a família do estudante; incentivo à participação do aluno em atividades extraclasse; organização de eventos que possibilitem aos alunos uma maior vivência acadêmica; trabalho colaborativo dos docentes do curso. Ao sistematizar os resultados referentes à questão, tem-se a seguinte configuração:

Gráfico 6 - Quais os principais fatores que levam um aluno (a) a evadir-se do curso.

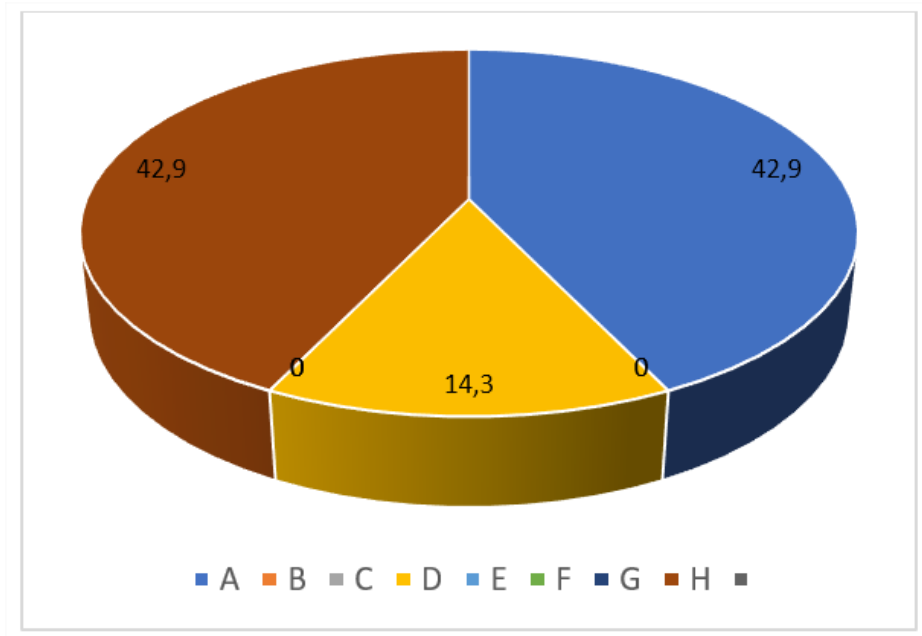

Fonte: Elaborado pelos autores a partir dos dados obtidos pelo questionário aplicado.

Como se pode observar, houve um empate entre opções, pois, para 42,9\%, a "concessão de bolsas/ajuda financeira" e "trabalho colaborativo dos docentes frente ao diagnóstico das dificuldades sociais e de aprendizagem dos estudantes" aparecem como primeira opção em termos de prioridade para combater a evasão. Para 14,3\%, o "diagnóstico das dificuldades dos alunos” foi 
a segunda opção mais escolhida para o combate à evasão, segundo os dados da pesquisa empírica. Outro ponto destacado, ainda dentro da análise do tema relacionado à evasão, ressalta, mais uma vez, a complexidade do assunto, frisando que cada curso apresenta uma "situação diferente". Às vezes, falta aptidão ao aluno (curso de música por exemplo); podem ocorrer dificuldades em conciliar trabalho com estudos; outro possível exemplo se refere à conhecida falta de perspectiva de trabalho de certas carreiras (Letras Francês).

Considerando o contexto de análise, é pertinente trazer à cena alguns dos elementos que, do ponto de vista prescritivo e normativo, auxiliam na análise e nas formas de intervenção na problemática anunciada, como é o caso do Regimento Geral da Ufac (2013), que, em seu Art. 70, explicita que é de competência do Colegiado do curso "refletir sobre o plano de acompanhamento do desenvolvimento do aluno durante o curso, realizando estudos sobre o índice de reprovação e evasão, bem como estabelecendo os prazos mínimo e máximo para conclusão do curso”.

Uma política estratégica adotada pela Ufac com vistas ao combate da evasão, dentre outras funções, foi a criação da Pró-Reitoria de Assuntos Estudantis (Proaes), instituída pela Resolução no 099, de 29 de novembro de 2012. Conforme consta no portal da Ufac, a Pró-Reitoria de Assuntos Estudantis é o órgão responsável pelo planejamento e execução da política de assistência estudantil da instituição e tem como finalidade promover ações afirmativas de acesso e inclusão social que buscam garantir a igualdade de oportunidades aos estudantes.

\section{Considerações finais}

Tendo em vista a questão de investigação proposta, combinada com outros elementos subsidiários, reconhece-se que, tanto os dados do Nurca, quanto as falas dos(as) coordenadores(as) apuradas no questionário não contribuíram de forma muito efetiva para agregar maiores elementos que pudessem favorecer o encaminhamento de respostas claras e objetivas às perguntas que nortearam o estudo. Apesar disso, ao considerar-se o conjunto das informações coletadas, tornou-se possível apreender dados, estabelecer conexões e extrair 
feedbacks importantes que serviram para tornar possíveis algumas inferências e depreensões às indagações postas.

Pode-se dizer que, mesmo de forma parcial, no que se refere aos principais fatores que contribuíram para a produção dos índices de evasão nos cursos analisados, conforme indicaram as respostas dadas pela maioria dos(as) coordenadores(as), existe a compreensão e o reconhecimento de que grande parte dos ingressantes dos cursos do Cela são oriundos de famílias de baixa renda, carentes e, predominantemente, compostas por pessoas vulneráveis, economicamente falando.

Essa configuração e realidade social impõem, dentre outros fatores, o entendimento de que esses alunos dependem de bolsas e auxílios, oferecidas pela IES, para que lhes sejam asseguradas, minimamente, condições de permanência na graduação e possibilidades de prosseguirem os estudos e concluírem a graduação sem maiores percalços.

A par disso, é possível inferir que, se nessas circunstâncias, o discente, por quaisquer motivos, não tenha acesso às bolsas e/ou auxílios oferecidos pela Ufac, o risco de evasão é elevado. Por esse motivo, considera-se muito preocupante o momento pelo qual passam as universidades públicas federais com os sucessivos cortes dos recursos públicos destinados à manutenção do ensino superior público, congelamento dos gastos públicos promovido pelo governo anterior e continuado de forma bem mais perversa pelo atual governo, com cortes orçamentários, redução das verbas de pesquisa e o consequente sufocamento das agências de fomento, fato que afeta desde a educação básica, passando pelo ensino superior e reverbera na pós-graduação.

Não resta dúvida de que o conjunto dessas medidas afeta tanto a universidade pública quanto o público que mais necessita dos programas de assistência e auxílio estudantil, os alunos em situação de vulnerabilidade socioeconômica, presentemente beneficiados pela política de cotas e que fizeram a adesão ao Sisu como mecanismo de seleção para chegar à universidade.

Diante do exposto, nunca será demais ressaltar que esses jovens já superaram um grande desafio ao terem cursado o ensino fundamental e o ensino médio em escolas públicas e que, ao chegarem à universidade, acabam, segundo relato dos coordenadores de curso participantes desta pesquisa, abandonando 
os estudos e optando pelo trabalho remunerado, seja por causa da vulnerabilidade financeira da família ou mesmo por força das necessidades de sua própria sobrevivência, pois alguns já têm, inclusive, famílias constituídas.

\section{Referências}

ADACHI, Ana Amelia Chaves Teixeira. Evasão e evadidos nos cursos de graduação da Universidade Federal de Minas Gerais. 2009. 214 f. Dissertação (Mestrado em Educação) - Faculdade de Educação, Programa de Pós-Graduação em Educação, Universidade Federal de Minas Gerais, Belo Horizonte, 2009. Disponível em: https://repositorio.ufmg.br/bitstream/1843/HJPB-7UPMBA/1/disserta__o_ana_am_lia_adachi.pdf. Acesso em: 23 mar. 2021.

ANDRIOLA, Wagner Bandeira. Fatores associados à evasão discente na Universidade Federal do Ceará (UFC) de acordo com as opiniões de docentes e de coordenadores de cursos. Revista Iberoamericana sobre Calidad, Eficacia y Cambio en Educación. Madrid, v. 7, n. 4, p. 343-356, 2009. Disponível em: https://repositorio.uam.es/bitstream/handle/10486/661287/REICE_7_4_18. pdf? sequence=1\&isAllowed=y. Acesso em: 23 mar. 2021.

BRASIL. Ministério da Educação. Comissão Especial de Estudos sobre a Evasão nas Universidades Públicas Brasileiras. Diplomação, retenção e evasão nos cursos de graduação em instituições de ensino superior públicas. Secretaria de Ensino Superior. Brasília, 1996.

BUENO, José Lino Oliveira. A evasão de alunos. Jornal da USP, São Paulo, USP, 14 a 20 de junho de 1993.

CAMPOS, Liliane Carla. Políticas de permanência estudantil em cursos de licenciaturas no período de 2007 a 2017: a experiência da Universidade Federal do Triângulo Mineiro. 225 f. Dissertação (Mestrado em Educação). Universidade Federal de Uberlândia, Uberlândia, 2018. Disponível em: https:// 
repositorio.ufu.br/bitstream/123456789/21109/1/PoliticasPermanenciaEstudantil.pdf. Acesso em: 23 mar. 2021.

FRITSCH, Rosangela. A problemática da evasão em cursos de graduação em uma universidade privada. Anais da Reunião Nacional da ANPEd, 37. 2015, Florianópolis: UFSC, 2015. Disponível em: https://anped.org.br/sites/ default/files/trabalho-gt11-3986.pdf. Acesso em: 23 mar. 2021.

GIRAFFA, Lucia Maria Martins; SANTOS, Pricila Kohls dos. Evasão na educação superior: um estudo sobre o censo da educação superior no Brasil. Pucrs, 2016. Disponível em: https://repositorio.pucrs.br/ dspace/bitstream/10923/8689/2/EVASAO_NA_EDUCACAO_SUPERIOR_UM_ESTUDO_SOBRE_O_CENSO_DA_EDUCACAO_SUPERIOR_NO_BRASIL.pdf. Acesso em: 23 mar. 2021.

PINTO, Phelipe Rodrigues de Oliveira. A movimentação de estudantes entre diferentes cursos da Universidade Federal de Viçosa e o processo de escolha do curso superior. 118f. Dissertação (mestrado) Universidade Federal de Viçosa, 2017. Disponível em: https:/www.locus.ufv.br/bitstream/123456789/24332/1/texto\%20completo.pdf. Acesso em: 23 mar. 2021.

RISTOFF, Dilvo. Evasão: Exclusão ou Mobilidade. Santa Catarina, UFSC, 1995 (MIMEO).

SIQUEIRA, Christiane Sarate. A evasão no curso de administração na modalidade EAD: Polo da Universidade UNOPAR de Petrópolis - RJ, 2017.

TINTO, Vincent. Dropout from higher education: a theoretical synthesis of recent research. Washington, Review of Educational Research, v. 45, n. 1, 1975, p. 89-125. Disponível em: https://journals.sagepub.com/ doi/10.3102/00346543045001089. Acesso em: 23 mar. 2021.

UNIVERSIDADE FEDERAL DO ACRE. Regimento geral da Universidade Federal do Acre. Rio Branco, Acre, 2013. Disponível em: http:// 
www.ufac.br/site/ocs/regimento-ufac.pdf/@@view/++widget++form.widgets. file/@@download/REGIMENTO+-+UFAC.pdf. Acesso em: 21 de jan. 2019. UNIVERSIDADE FEDERAL DO ACRE. Ufac 2014-2023: Planejamento e gestão estratégica Planejamento estratégico. Universidade Federal do Acre, 014.

VITELLI, Ricardo Ferreira; FRITSCH, Rosangela. Evasão escolar na educação superior: de que indicador estamos falando? Estudos em Avaliação Educacional, v. 27, n. 66, p. 908-937, 2016. Disponível em: http://publicacoes.fcc. org.br/index.php/eae/article/view/4009/3277. Acesso em: 23 mar. 2021. 


\section{EIXO II - QUESTÕES \\ EDUCACIONAIS EM PERSPECTIVA}




\section{A ÉTICA DA ALTERIDADE COMO CAMINHO PARA A EDUCAÇÃO FACE À DIVERSIDADE SOCIOCULTURAL AMAZÔNICA}

Wesley Cristian Mercês Teixeira

Rosângela de Fátima Cavalcante França

Eulina Maria Leite Nogueira

\section{Introdução}

Pensar na Amazônia é pensar em diversidade. Seja por conta da biodiversidade local, que abrange variadas espécies de fauna e flora e os mais ricos e diversificados ecossistemas do planeta, muitos ainda desconhecidos pela comunidade científica, seja por conta das diversificadas populações que nela residem - indígenas, caboclos, quilombolas, migrantes etc.

E, se pensar na Amazônia já nos direciona a uma diversidade sociocultural, podemos assim também pensar a educação na região, uma vez que esta diversidade chega também às escolas e precisa ser trabalhada de maneira coerente com a realidade sociocultural na qual estão inseridas. Sabedores disto, buscamos discutir meios para pensar a educação frente à diversidade sociocultural da Amazônia.

Assim, neste trabalho, fruto de um estudo bibliográfico, abordaremos a questão da diversidade cultural da Amazônia, que perpassa a sua biodiversidade, mas que é percebida também em sua heterogeneidade sociocultural para, em um segundo momento, discutirmos a proposta do multiculturalismo, em especial o Multiculturalismo Crítico, defendido por Peter McLaren (2000), como uma alternativa para uma educação que pudesse contemplar tal diversidade cultural.

Por fim, apresentamos a Ética da Alteridade de Emmanuel Lévinas, como fundamento de uma educação pautada na relação com o Outro em sua absoluta diferença, que permite um ensino como abertura em relação à diferença o que poderá possibilitar um novo olhar acerca da diversidade amazônica na sala de aula. 


\section{A diversidade cultural da Amazônia}

A diversidade amazônica pode ser considerada em diversos aspectos: seja em sua biodiversidade e riquezas de ecossistemas, seja nas diversas organizações e modos de produção ali existentes, ou na diversidade sociocultural advinda das diversas populações que ali residem.

Destacamos, assim, a diversidade sociocultural, marcada pela confluência de culturas diversas que, ao adentrar na Amazônia, acabam por mesclar-se com a dos povos que ali residem.

Um ponto inicial a se considerar é que a diversidade, ou heterogeneidade, é algo característico da Amazônia (Corrêa; Hage, 2011, p. 82; Lopez, Nenevé; Amaral, 2013, p. 206; Fraxe, Witkoski; Miguez, 2009, p. 30).

Quanto a isto, Corrêa e Hage (2011) afirmam que tal heterogeneidade se constitui em diversos aspectos, dentre os quais destacam as heterogeneidades ambiental, produtiva e sociocultural.

No que tange à heterogeneidade ambiental, os autores ressaltam a variedade de ecossistemas existentes na região. Esta biodiversidade, embora parcialmente desconhecida pela comunidade científica, já é conhecida e utilizada pelas populações tradicionais (Corrêa; Hage, 2011, p. 82).

Quanto à heterogeneidade produtiva, destacam os autores, a convivência de modos de produção contraditórios e conflituosos dentro do espaço amazônico. Evidencia-se, assim, a existência de grandes empreendimentos ligados ao grande mercado, com destaque a extração e exploração de madeira, à pecuária extensiva e ao agronegócio, em contradição e conflito com modos como a agricultura familiar e trabalhos cooperativos (Correa; Hage, 2011, p. 87-92).

Por fim, a heterogeneidade sociocultural, à qual queremos dar ênfase neste estudo, refere-se à diversidade sociocultural amazônica, composta por populações diversas que habitam o mesmo espaço: indígenas, quilombolas, caboclas ribeirinhas e da floresta, sem-terra, assentadas, pescadores, camponesas, posseiras e migrantes de outras regiões do país (Corrêa; Hage, 2011, p. 85).

Estes grupos estão distantes de compor uma homogeneidade, acentuando ainda mais este rico mosaico heterogêneo que compõe a realidade socio- 
cultural amazônica, como destacam Lopez; Nenevé; Amaral (2013, p. 206) ao enfatizar a realidade "singular e plural" da região, a qual é "[...] carregada de muitas identidades que transbordam em diferenças".

Deste modo, a constituição sociocultural da região amazônica é fortemente marcada por esta convivência de identidades e origens diferenciadas, que, ao conviverem com as características específicas do ecossistema da região, acabam por mesclarem-se, dando origem a novos modos de vida, como afirmam Corrêa; Hage (2011, p. 86):

[...] a formação das identidades culturais da Amazônia é muito complexa, pois aos saberes, valores e modos de vida indígenas, inicialmente predominantes na região, foram impostos outros padrões de referências advindos dos colonizadores europeus, dentre os quais destacam-se: portugueses, espanhóis, franceses, holandeses, ingleses. Essa matriz cultural amazônica é constituída, ainda, por raízes das populações asiáticas, japonesas, populações orientais, os judeus e sírio-libaneses, e imigrantes nordestinos e de outras regiões brasileiras, além da matriz, mais recente, norte-americana.

A realidade sociocultural amazônica é, portanto, fruto da confluência de diversos grupos culturais, os quais acabaram se mesclando - seja pela convivência ou pela imposição de uma cultura sobre outra - dando origem a este contexto sociocultural heterogêneo.

Não é demais reiterar que, embora haja uma certa cultura identificada como própria da Amazônia, esta mesma, como exposto, fora construída da confluência de diversas outras culturas ali residentes.

Assim, enfatizamos que a diversidade é característica da Amazônia, sendo constatável em sua diversidade sociocultural, a qual se manifesta na convivência destes diversos grupos culturais que dividem este território - caboclos, povos indígenas, alguns quilombolas e migrantes - que aqui se instalam e trazem também sua cultura para a região.

Ora, se o próprio contexto sociocultural amazônico é constituído por uma realidade heterogênea e diversa, faz-se necessário nos questionar de que 
forma esta diversidade pode ser trabalhada na educação, de modo a contemplar toda esta riqueza cultural destacada.

Um caminho possível tem sido proposto através da perspectiva do multiculturalismo, a qual passaremos a discutir.

\section{Um caminho através do multiculturalismo}

Uma vez que constatamos ser a região amazônica marcada por uma grande diversidade sociocultural, podemos facilmente inferir que a educação na região amazônica também seja perpassada por esta mesma diversidade de povos e culturas.

Ante a esta inferência, nos propomos a buscar soluções que possibilitem à educação contemplar esta diversidade que expusemos. Um dos caminhos possíveis encontrados na literatura é o chamado multiculturalismo, como conjunto de crenças e práticas que visam a integração cultural.

A questão proposta é: o multiculturalismo seria capaz de contemplar a diversidade sociocultural da região amazônica?

Embora a diversidade cultural amazônica seja algo perceptível, nem sempre, esta encontra lugar nas políticas e práticas da educação na região amazônica. Lopez, Nenevé e Amaral (2013, p. 208-209) destacam que, por vezes, a escola acaba por reproduzir o discurso colonizador, que exalta belezas e riquezas de outros lugares, enquanto despreza a diversidade cultural local.

Assim, as culturas locais, em geral, têm encontrado pouco espaço nas escolas amazônicas, seja nos textos lidos em sala, que possuem sempre referências externas as realidades cotidianas dos alunos, com exemplos, autores e referências vindas de outras regiões, sobretudo, nos currículos, práticas e ritmos que não acompanham integralmente as peculiaridades próprias da região.

Faz-se necessário, nesse contexto, repensar a educação na região, a fim de encontrar novas práticas, currículos e meios de se educar que possam contemplar a diversidade sociocultural da região.

Neste sentido, Lopez, Nenevé e Amaral (2013), bem como Corrêa e Hage (2011) concordam em apontar no Multiculturalismo um caminho para repensar a educação na Amazônia, com abertura à riqueza cultural que lhe é característica. 
Nenevé (apud Lopez; Nenevé; Amaral, 2013, p. 207) assim define o multiculturalismo:

\begin{abstract}
O multiculturalismo é um sistema de crenças e comportamentos que reconhece e respeita a presença de todos os grupos diversos em uma organização ou sociedade, reconhece e valoriza as suas diferenças socioculturais e estimula e capacita sua contribuição continuada com um contexto cultural inclusivo dando poder a todas as pessoas nesta organização ou sociedade.
\end{abstract}

Por multiculturalismo se entende, portanto, o conjunto de práticas, crenças e comportamentos que visam o reconhecimento das diferenças no campo social e político, com a aceitação do outro.

Outra interessante definição nos é dada por Skliar (2003, p. 123), para quem o multiculturalismo pode ser definido tanto como uma consciência que se opõe a todas as formas de "centrismo" (o que também pode ser traduzido nas várias revoltas contra estes - antirracismo; antissexistas; antidiscriminatórias; etc.), um discurso que poderia conduzir a uma nova produção de conhecimento sobre o outro, uma forma de disputa em torno dos poderes e hierarquizações das representações sobre as diferenças, consideração da diversidade como tópico crucial de toda a descrição política e uma enunciação, ainda que tênue e ambígua, de uma política da identidade e da diferença.

O canadense Peter McLaren (2000), em seus estudos, aponta a existência de quatro diferentes formas do multiculturalismo. São elas: o multiculturalismo conservador, o multiculturalismo humanista liberal, o multiculturalismo liberal de esquerda e o multiculturalismo crítico.

O multiculturalismo conservador pode ser percebido desde as primeiras visões coloniais sobre as pessoas afro-americanas com escravas, inferiores e comparáveis a animais. Esta perspectiva, com a falsa promessa de criação de uma "cultura comum", permite que o outro diferente possa conviver dentro do mesmo espaço cultural, porém introduzidos dentro de uma cultura dominante. Estes grupos culturais acabam por tornar-se meros "acréscimos 
à cultura dominante”, porém, para isto, você precisa, primeiramente, aceitar as normas "patriarcais essencialmente euro-norte-americanas do país 'hospedeiro"' (Mclaren, 2000, p. 114-115).

Skliar (2003, p. 129) afirma que esta forma de multiculturalismo é simplesmente uma perspectiva neocolonial, que abusa da ideia de diversidade para encobrir sua própria hostilidade. Há, assim, a autorização para que o alguns outros, os "diferentes", continuem sendo o que são, mas dentro de um certo espaço de oficialidade.

Quanto ao multiculturalismo humanista liberal, este baseia-se numa crença na existência de uma igualdade natural entre os homens. As diferenças existentes são, assim, resultado da falta de oportunidades sociais, legais e/ou educativas que possam permitir que todos possam competir de forma igualitária no mercado capitalista (Mclaren, 2000, p. 61; Skliar, 2003, p. 134).

Sobre esta forma de multiculturalismo, Skliar (2003, p. 134-135) refere-se como uma tentativa de "igualitarismo" que se converte em pressões etnocêntricas para que o outro se enquadre em uma norma que nunca pode ser equivalente.

O outro, nesta perspectiva é, portanto, concebido como igual em certa dimensão. Toda diferença e diversidade é, assim, vista somente como entraves a serem superados, o que revela certa intenção de englobar todas as diferenças em uma certa "norma" padrão a ser seguida em nome de um ideal de igualdade.

O multiculturalismo liberal de esquerda, por outro lado, enfatiza as diferenças culturais. Críticos de outras tendências multiculturalistas, os que trabalham nesta perspectiva afirmam que aquelas escondem, obstaculizam, reprimem, extinguem ou atenuam tais diferenças (Mclaren, 2000, p. 120; Skliar, 2003, p. 135).

Essa forma de multiculturalismo tende, ainda, a "essencializar" tais diferenças, assumindo que haja uma forma de ser mulher, uma forma de ser afro-americano, essências que existem independente da história, cultura ou relação do poder.

Por fim, o multiculturalismo crítico trata-se de um multiculturalismo aliado a uma agenda política de transformação social. McLaren (2000, p. 123) afirma que esta perspectiva "compreende a representação de raça, classe e gênero como o resultado de lutas sociais mais amplas sobre signos e significações”, mas, para além disso, entende que esta tem "a tarefa central de transformar as relações sociais, culturais e institucionais nas quais os significados são gerados”. 
Tem-se assim a rejeição a uma imagem de cultura não-conflituosa, harmônica e consensual, ao mesmo tempo que se opõe a ideia da existência de identidades autônomas. As diferenças são frutos de uma luta social e, uma perspectiva multiculturalista crítica só poderia existir se contrapusesse-se à política de significações excludente que as distancia.

Seria, então, o multiculturalismo, em sua forma crítica, um caminho para a construção de uma educação que atenda à diversidade cultural amazônica?

Em um primeiro olhar, poderíamos responder positivamente, uma vez que sua premissa é a abertura ao reconhecimento do outro e a transformação social das fontes desta diferenciação.

Lopez; Nenevé e Amaral (2013, p. 209) defendem, dentro de uma perspectiva multiculturalista, que se possibilite ao docente e ao discente serem sujeitos das novas formas de conhecimento. Para eles, o docente deve defender um currículo multicultural, carregado de diversidade, além de se sentir sujeito ativo das mudanças sociais e, por fim, perceber o discente como um ser inteiro, que considere sua formação histórica, étnica e cultural.

Contudo, pensamos ser importante destacar a crítica feita por Skliar (2003, p. 141, grifo nosso) à perspectiva multiculturalista:

Talvez o outro multicultural não possa ser mais do que outro que flutua, pois está representado como um pêndulo entre o eu plural, o mesmo plural e a emergência da diferença só como diversidade ordenadamente política, isto é, o outro político da política da mesmidade, o outro da igualdade do igualitarismo, das equivalências pensadas somente em termos de administrações identitárias, das distribuições políticas e das representações delegadas e descritas culturalmente.

Assim, o outro do multiculturalismo é sempre comunitário, sempre em grupo, cujas diferenças sejam facilmente traduzidas em termos fixos: raça, etnia, credo, sexualidade, gênero, escolaridade, etc. É o outro quantificável, passivo de ser estudado, teorizado e de ser alocado politicamente.

Para Skliar (2013, p. 132-133), isto não liberta o diferente, mas somente aprofunda a relação com o que ele chama de retórica da tolerância. A tolerân- 
cia é, sem dúvida uma maneira de admitir a existência da diferença, contudo, segundo o autor, ela possui grande relação com a indiferença. $\mathrm{O}$ risco da tolerância é que ela se torna um mecanismo de esquecimento, que pode levar a mera aceitação do outro, onde tolerar significa que aquele a quem se tolera é censurável de alguma forma, mas, pela convivência múltipla, se tolera.

Ademais, críticas semelhantes também podem ser encontradas nas obras de Emmanuel Lévinas (2016a; 2016b; 1993), para quem a busca por conhecer o Outro será sempre um retorno àquilo que sabemos de nós mesmos. Uma vez que se transforma em um grupo, um coletivo, um agrupamento de alteridades para definir um "nós" - o amazônico, o indígena, o caboclo, etc. acaba-se por negar a alteridade de cada indivíduo.

Vale ressaltar que, reconhecer a diversidade amazônica deve implicar, a reconhecer os diversos grupos culturais que constituem a heterogeneidade cultural da região, mas também deve nos provocar a reconhecer que esta realidade é percebida e vivenciada de forma diferente para cada indivíduo.

Assim, uma vez que reconhecemos que a escola da Amazônia é perpassada pela diversidade cultural que é característica da região, a educação na região deveria atender à esta diversidade.

Entre os possíveis caminhos para chegar a este objetivo, encontra-se resposta no multiculturalismo, como práticas e crenças que buscam a integração das diversidades socioculturais.

Contudo, conforme exposto, pensamos ser possível ir além da proposta do multiculturalismo, para assim desviar da retórica da tolerância e da redução da alteridade a grupos pré-estabelecidos, permitindo à educação uma abertura ainda maior à alteridade de cada indivíduo.

Somente um caminho que permita perceber o outro, sua alteridade, em cada indivíduo, poderia ser capaz de abarcar toda a realidade amazônica em suas diversas manifestações. Uma perspectiva capaz de contemplar toda esta dimensão da diversidade amazônica pode ser encontrada a partir da filosofia de Emmanuel Lévinas, a qual passaremos a apresentar. 


\section{Um caminho a partir da ética da alteridade}

Pensar em educação é também pensar o ser humano. Se pensamos o ser humano diante do cenário de diversidade sociocultural anteriormente descrito, se torna óbvio que a educação deve - ou deveria - ser pensada a partir deste homem da diversidade cultural.

Tomamos, deste modo, a concepção levinasiana de ser humano como ser-em-relação como uma forma de pensar a complexidade da diversidade cultural na Amazônia. Destacando a noção de alteridade como o ser do Outro, um infinito irredutível com o qual me relaciono.

Partindo da filosofia levinasiana, propomos um ensino voltado para a relação come o Infinito do Outro, que permita a relação sensível à todas as alteridades que se manifestam no ambiente educativo para assim contemplar a vastidão cultural da região amazônica.

\section{A ética da alteridade de Emmanuel Lévinas}

Compreender a filosofia de Emmanuel Lévinas é, a priori, compreender a sua concepção de homem: Para ele, o homem é essencialmente relação, desde sua relação com os objetos da existência e, principalmente, na relação com o Outro, na qual o sujeito é posicionado passivamente. Desta relação passiva com o Outro, deriva-se a ética, como responsabilidade irrefutável pelo outro homem.

Pensar o ser enquanto relação é estabelecer o caráter relacional do ser em primazia ao ontológico. Desde sua interioridade, para Lévinas (2016a, p. 100), o ser constitui-se em relação com outros entes e outros seres, as quais dão sentido à própria existência.

Sobre isso, Susin (1984, p. 33) afirma que o homem levinasiano é um "ser-em-relação", um ser que está em constante relação com o mundo, sempre com o que lhe é externo. Deste modo, a condição de existência do homem é a relação e existir é sempre ir além de si mesmo, como afirma Lévinas (2016a, p. 101-102):

Viver é como verbo transitivo em que os conteúdos da vida são os complementos directos. E o acto de viver os conteúdos é, ipso facto, conteúdo 
a vida. [...] A vida é amor da vida, relação com conteúdos que não são o meu ser, mas mais caros que o meu ser: pensar, comer, dormir, ler, trabalhar, aquecer-se ao sol. Distintos da minha substância, mas constituindo-a, esses conteúdos constituem o preço da minha vida.

Desta forma, na relação com os objetos da existência é que o ser humano se estabelece no mundo e dele frui. Contudo, há um tipo de relação que não pode ser reduzida a mera fruição: a relação com o outro homem, que Lévinas (2016a, p. 34; 1993, p. 52) chama de ética.

É especificamente neste ponto que a filosofia de Lévinas encontra o seu ápice: a existência humana não é somente relação, como é uma relação ética (Lévinas, 2016a, p. 34; 1993, p. 52), ou, nas palavras de Pivatto (2014, p. 81): "[...] a ética é o sentido profundo do humano e precede a ontologia".

A ética, portanto, dá o sentido à existência humana, pois é na relação com o Outro que se dá o sentido e o significado do mundo, não de maneira teórica, mas concreta, nas relações e vivencias dos homens e suas próprias necessidades.

Para Lévinas (2016a, p. 29-35), esta relação entre o Mesmo e o Outro tem sido pensada pela tradição filosófica, na maioria das vezes, como uma redução do Outro ao Mesmo. A busca por conhecer o Outro acaba resultando em sua redução àquilo que o Mesmo já possui e já compreende.

Assim, Lévinas inverte a relação: não é do Eu Mesmo que esta deve partir, mas do Outro. O homem levinasiano não é o doador de sentido que "captura" o Outro para compreendê-lo, mas antes é o ser passivo que se coloca em posição de abertura e susceptibilidade em relação ao Outro (Lévinas, 1993, p. 95). Assim, o Outro é o polo de maior altura na relação, ele é alteridade pura, ele é absolutamente Outro, irredutível e infinito.

Irredutível porque se recusa a posse, porque não aceita ser tematizado ou reduzido, é Outro e não se mescla com a minha ipseidade. Nas palavras de Lévinas (2016a, p. 24): “O que é absolutamente outro não só se recusa à posse, mas contesta-a”.

E infinito porque sempre ultrapassa a ideia que se tem dele (Susin, 1984, p. 224). “O infinito é o absolutamente outro”, afirma Lévinas (2016a, p. 36). O 
Outro cuja altura e distância são tamanhas que, embora se tome consciência de algum aspecto, este sempre estará aberto e suscetível a mudanças que o $\mathrm{Eu}$ jamais será capaz de contemplar.

Por ser o polo ativo da relação, é o próprio Outro quem se revela e se manifesta, dotado de sentido em si mesmo e sua manifestação é uma epifania de si próprio, que Lévinas (2016a, p. 38; 1993, p. 58) chama de epifania do Rosto.

O Rosto é a expressão máxima do Outro, na qual ele mesmo se revela a partir da relação estabelecida com o Eu. Esta revelação não evoca categorias imanentes, mas, como presença viva, parte de sua realidade concreta, da sua significação em si próprio (Lévinas, 2016a, p. 54). Assim, a revelação do Outro é a sua manifestação tal qual é, a exposição de sua nudez, sua fragilidade e pobreza.

Se de um lado temos o Outro como polo ativo da relação ética, do outro, obviamente, temos o Eu em posição a qual é chamada por Lévinas de passividade (Lévinas, 2016b, p. 85; 156; 1993, p. 118).

Passividade - um posicionamento do ser que não se confunde com inércia, mas antes uma posição de abertura e suscetibilidade em relação ao Outro. O Eu é um ser de relações, contudo é também o polo passivo dessas relações: o Eu é sempre exposto ao Outro, é suscetível a ele, portanto, passivo.

A contemplação do Rosto - como manifestação do Outro - impacta o eu em sua posição de passividade. Este encontro é traumático, pois o Rosto se expressa, expõe suas necessidades pela sua fragilidade - está nu e sente fome. Esta nudez exige do Eu uma posição, ordena sem que lhe seja dada autoridade, constrange a subjetividade e exige uma resposta: surge a Responsabilidade por Outrem.

Esta Responsabilidade nasce da relação entre o Eu e o Outro, não por uma superioridade do Outro sobre o Eu, mas para Lévinas (2016a, p. 195), surge especificamente da sua fragilidade, cujo apelo se faz ouvir e do qual o Eu não consegue escapar.

A ética levinasiana aponta, assim, para uma relação responsável com o Outro, este compreendido como um ser de alteridade infinita e irredutível. Tal relação se fundamenta na passividade - posição pela qual o sujeito se relaciona de forma aberta ao Outro. Permitindo, assim, a sua própria manifestação como Rosto. 
Este imperativo de Lévinas por uma relação aberta ao Outro e a sua infinitude, onde o Outro, não o Eu, seja o polo ativo, nos permite pensar na possibilidade de, trazendo estes princípios à educação, estabelecer uma relação com a diversidade na educação que seja capaz de lidar com a diversidade.

Passamos, por fim, a investigar as formas como a filosofia levinasiana pode ser convergida à educação e, assim, de que forma esta pode contribuir para pensar a educação diante da diversidade sociocultural da Amazônia.

\section{O ensino a partir da ética da alteridade}

Falar sobre educação a partir da Ética da Alteridade de Emmanuel Lévinas pode se tornar um grande desafio. Principalmente porque em seus escritos Lévinas não aborda diretamente o tema da educação.

Contudo, falar em educação implica falar da relação entre, no mínimo, dois sujeitos: um que ensina e o outro que aprende. Assim sendo, a educação pressupõe uma relação entre pelo menos dois seres diferentes.

Dessa maneira, as ideias de Lévinas acerca da relação entre o Eu e o Outro, a partir da qual o Outro, irredutível e infinito, se torna o polo ativo desta relação, poderia trazer elementos interessantes à educação.

Inicialmente, é importante recordar que, para Lévinas, o homem é fundamentalmente relação, "ser-em-relação”, segundo Susin (1984, p. 33), sendo o caráter relacional a condição da existência do homem. Porém, é o próprio Lévinas quem ressalta que a primeira e fundamental relação é a relação ética, relação do homem com o Outro homem, a intersubjetividade (2016a, p. 30; 2016b, p. 113).

Esta constatação, todavia, nos remete à forma como Lévinas descreve a relação intersubjetiva - uma relação com um Outro dotado de uma alteridade própria e infinita.

Como já destacamos anteriormente, a concepção de alteridade em Lévinas (2016a, p. 25; 2016b; p. 83; 1993, p. 62) está na própria realidade do Outro, este que é por si manifestação de uma diferença absoluta que existe antes mesmo do eu, diferença esta que é, ao mesmo tempo, infinita e, consequentemente, de impossível apreensão. 
Assim, ao pensarmos o aluno como Outro, onde se manifesta a ideia de Infinito, nos deparamos com uma realidade única, irredutível a qualquer outra realidade e impossível de ser totalmente conhecida.

Isto faz com que o contexto relacional no qual a educação ocorre se torne também um fenômeno imprevisível, aberto a todas as possibilidades inerentes a este infinito desconhecido do aluno.

Torna-se necessário, então, outra forma de ensinar, que permita a expressão do Outro, de sua alteridade, e isso exige certa abertura por parte daquele que ensina, abertura à revelação do Outro que se manifesta em cada aluno ou aluna em sua classe. À esta abertura, Todd (2003, p. 137; 2011, p. 73) chama "ensino com ignorância" (teaching with ignorance).

O termo "ignorância" é tomado como sinônimo de "desconhecimento" e implica em uma postura do professor que deve ensinar ao mesmo tempo que se posiciona de forma aberta e sensível em relação a seus alunos.

Todd (2003, p. 137) descreve esta postura como sendo uma "atitude de humildade" que permita ver a luta de cada aluno como única, “[...] inacessível a sistemas de significações, teorias e conhecimento”.

Esta atitude se trata de um compromisso por parte do professor, compromisso que não pode ser resumido ao conhecimento, mas à atitude de escuta que permita aprender do Outro, de suas próprias experiências e sentimentos.

De forma muito semelhante, Skliar (2003, p. 200-201) menciona uma "Pedagogia da Perplexidade", afirmando a necessidade de se pensar em uma “educação que nunca termina e nunca se ordena”, isto é, aberta à novidade do Outro, à sua diferença. Esta educação se trata, segundo Skliar (2003, p. 200), de

[...] uma pedagogia descontínua que provoque o pensamento, que retire do espaço e do tempo todo saber já disponível; que obrigue a recomeçar do zero, que faça da mesmidade um pensamento insuficiente para dizer, sentir, compreender o que aconteceu; que emudeça a mesmidade.

Tem-se assim, uma educação aberta ao Outro, uma educação criativa e orientada tão somente ao Outro, que modifica o processo continuamente, uma 
pedagogia que, segundo Skliar (2003, p. 208), “[...] se auto reforma, fazendo metástase em nós e na alteridade”.

Esta modalidade de ensino precisaria centrar-se na relação entre os sujeitos e a todo tempo questionar-se acerca da qualidade destas relações. Para Lévinas (2016a, p. 165), o ensino é exterioridade, uma transcendência: o Eu que se abre e oferece seu mundo ao Outro.

Assim, a educação pautada pela filosofia levinasiana, seria uma educação sempre aberta ao Outro, não com o objetivo de conhecê-lo ou descrevê-lo, mas disposta a se surpreender com ele e (por que não?) aprender com ele.

Esta educação, aberta à alteridade, a cada indivíduo, poderia, assim, tornar-se capaz de contemplar a rica diversidade amazônica descrita anteriormente.

Sem o ensejo de dividir em grupos e teorizar o que seja uma cultura amazônica, estando abertos à revelação de cada indivíduo em sala de aula, o docente poderia encontrar-se de maneira pura com o ser absolutamente Outro de cada aluno, relacionando-se assim com o mistério infinito que cada um transforma a partir da realidade na qual estão inseridos.

\section{Conclusão}

A diversidade é uma característica marcante da região amazônica. Sua rica biodiversidade chama atenção por seus diversificados - e complexos - ecossistemas.

Mas a Amazônia também é berço de outras diversidades, entre as quais destacamos sua diversidade sociocultural: a região é marcada pela convivência (nem sempre pacífica) de diversas culturas, povos e populações, algumas originárias, outras que para ali migraram e outras que se constituíram da hibridização destas culturas que por ali passaram, dando origem ao modo de ser amazônico, profundamente vinculado ao ecossistema local.

E como pensar a educação diante desta diversidade sociocultural amazônica?

Num primeiro momento encontramos resposta num Multiculturalismo Crítico, comprometido com a transformação social a partir do reconhecimento 
das diferenças que possibilite a participação dos sujeitos diferentes na luta social pela desconstrução das desigualdades.

Contudo, dele nos distanciamos para um caminho ainda mais profundo ao propor um ensino baseado na filosofia de Emmanuel Lévinas, a partir da qual propomos um ensino pautado pela Ética da Alteridade. Um modo de ensinar aberto ao infinito e ao mistério do Outro, onde a diferença de cada indivíduo é valorizada como expressão única.

Pensar a educação a partir desta perspectiva é pensar uma educação centrada nas relações intersubjetivas, onde ensino é um ato ético de abertura para o Outro, em sua alteridade. Abertura não com o objetivo de conhecer o Outro e descrevê-lo, mas aberta em perplexidade, para se encantar e, também, aprender dele.

\section{Referências}

CORRÊA, Sérgio Roberto Moraes; HAGE, Salomão Antônio Mufarrej. Amazônia: a urgência e necessidade da construção de políticas e práticas educacionais inter/multiculturais. Revista NERA, Presidente Prudente, ano 14, n. 18, p. 79-105,Jan-Jun, 2011. Disponível em: https://revista.fct.unesp.br/index. php/nera/article/view/1336/1326. Acesso em: 23 mar. 2021.

FRAXE, Therezinha de Jesus Pinto; WITKOSKI,Antônio Carlos; MIGUEZ, Samia Feitosa. O ser da Amazônia: identidade e invisibilidade. Cienc. Cult. [online], vol.61, n.3, p. 30-32, 2009. Disponível em: http://cienciaecultura.bvs. br/pdf/cic/v61n3/a12v61n3.pdf. Acesso em: 23 mar.2021.

LÉVINAS, Emmanuel. Totalidade e infinito. 3. ed. Lisboa, Portugal: Edições 70, 2016a.

LÉVINAS, Emmanuel. Entre nós: ensaios sobre a alteridade. 5. ed. Petrópolis: Vozes, 2016b.

LÉVINAS, Emmanuel. Humanismo do outro homem. Petrópolis: Vozes, 1993. 
LOPEZ, Nuria Sagué; NENEVÉ, Miguel; AMARAL, Nair Ferreira Gurgel do. Por um Ensino Multicultural na Amazônia. Revista Igarapé Literatura, Educação e Cultura: Caminhos da Alteridade, Porto Velho, n. 2, p. 203-218. Set, 2013. Disponível em: https://www.periodicos.unir.br/index.php/igarape/ article/view/748/804. Acesso em: 23 mar. 2021.

MCLAREN, Peter. Multiculturalismo crítico. 3. ed. São Paulo: Cortez, 2000. PIVATTO, Pergentino S. Ética da Alteridade. In: OLIVEIRA, Manfredo A. (org.). Correntes fundamentais da Ética Contemporânea. Petrópolis, RJ: Vozes, 2014, p. 79-97.

SKLIAR, Carlos. Pedagogia (improvável) da diferença: e se o outro não estivesse aí? Rio de Janeiro: DP\&A, 2003.

SUSIN, Luiz Carlos. O homem messiânico: uma introdução ao pensamento de Emmanuel Lévinas. Petrópolis: Vozes, 1984.

TODD, Sharon. Learning from the other: Lévinas, psychoanalysis and ethical possibilities in education. Nova York: State University of New York Press, 2003.

TODD, Sharon. On not Knowing the Other, or Learning from Levinas. Philosophy of Education Yearbook. Illnois, 2011, p. 67-74. 


\section{A EDUCAÇÃO COMO PRÁTICA DE LIBERDADE É PARA TODAS AS PESSOAS?}

Rosangela Aparecida Hilário

Vinícius de Souza Santos

Escolhas são, em grande medida, resultado e resultante de vivências. Logo, são pessoais e biográficas, pautadas a partir de nossas experiências no uso de teorias, tecnologias, palavras e experiências para organizar ações com as quais vamos contar nossas histórias. Portanto, antes de iniciarmos a reflexão faz-se necessário evidenciar nossa opção de escrever em primeira pessoa do plural, e diante desta proposição, tecer conexões e simetrias entre o que defendemos e o que vivemos.

A formação acadêmica brasileira ainda que se situe na periferia dos sistemas de produção das ciências, sobretudo no que diz respeito às ciências da educação, se encontra acomodada na máxima permitida pelo pensamento cartesiano de que "penso, logo existo" (existo porque penso; penso, logo conquisto, cfe. Maldonado Torres, 2007). Portanto, ao cientista é exigido uma objetividade e neutralidade com os fenômenos incompatíveis com uma noção de mundo onde caibam a pluralidade, as contradições e desconforto necessário para produção de múltiplos modos de produzir e entender como saberes são (ou não) ratificados e apropriados pela Academia.

O conhecimento, tal e qual proclamado por Descartes, foi traduzido a partir de um paradigma que dividiu o mundo entre o sujeito universal: homem, branco, europeu, cristão e comprometido com a expansão de territórios geográficos e epistemológicos para manter a farsa da história única e visão hierárquica de pessoas e conhecimento, e sua contraposição. Ou, como todas as outras categorias não contempladas por essa definição são excluídas de processos de assunção plena a existência.

Assim, se a ciência fosse traduzida em uma imagem seria a do homem europeu pensante e pensador compartilhando gotas de conhecimento com o 
resto da humanidade, enquanto dialoga com seus iguais em uma língua só entendida por poucos escolhidos. Essa é a ética que persiste e insiste em se perpetuar como cânone científico em franca oposição a tudo que ameace sua posição. É a ética do dualismo e das exclusões.

Descartes conseguiu proclamar um conhecimento não-situado, universal, visto pelos olhos de Deus [...] ao esconder o lugar do sujeito da enunciação, a dominação e a expansão coloniais europeias/euro-americanas conseguiram construir por todo o globo uma hierarquia de conhecimento superior e inferior e, consequentemente, de povos superiores e inferiores (Grosfoguel, 2008, p. 120).

Isso posto, justificamos a escrita de um texto acadêmico em primeira pessoa do plural como processo de resistência para existência na academia de corpos que não são desejáveis na produção das ciências: pobres, pretos, pretas, viadas, afeminados, mulheres e suas especificidades e mulheres pretas (menos ainda). A marca do "pretogues" criado e traduzido nos textos de Lélia Gonzales (2020) é a escolha para demarcar esse espaço de produção. As ciências que fazemos são retroalimentadas pela escuta e partilha das narrativas e processos dos corpos desobedientes para anunciarem suas estratégias para assunção ao estado de direito. Para nós, aprender e internalizar o conhecimento posto é o primeiro passo para reorganizá-lo a partir de uma proposta de inclusão. Nenhum conhecimento precisa ser produzido se não serve a todas as pessoas.

[...] justifico também as escolhas pelo 'pretoguês' me recuso a me identificar de acordo com as regras e semântica opressoras da linguística racista e eurocentrada: sou preta. Negra é como me definem os manuais do colonizador, a partir de sua métrica e desejo de ser/estar para cima da periferia do mundo (Hilário, 2019, p. 48).

Assim escrever em primeira pessoa tem a ver com as "escrivivências" de nos percebemos cientistas em processo de ressignificação dos espaços trilhados. Nem tudo que foi ensinado no processo de formação serve ao entendimento dos usos para o acesso democrático ao conhecimento. Nem todo 
conhecimento serve a pauta da inclusão e aos textos que produzimos e para quem produzimos, resultados das ausências, da memória e de tempos e espaços que a academia não se ocupa e não tem interesse. Produzimos a partir do reconhecimento de uma identidade afroameríndia, para além do conceito de amefricanidade, considerando o percurso constitutivo acontecer em um pedaço da Amazônia, lugar em que resistimos, aprendemos e convivemos com a faceta multifacetada da mestiçagem. A objetividade deste texto é a possível diante do sentido que ser um corpo desobediente da norma trouxe ao papel de ser vivente que produz saberes que permitam fazer escolhas.

Justificada as escolhas e apresentada as credenciais, cercamo-nos de referências que preenchem o vazio de não ter outras como nós para dialogar nos espaços acadêmicos, por meio da leitura de intelectuais pretas forjadas na dor do preterimento, das ausências e da resistência para abrir caminhos para que outras possam se fazer ouvir e reverberar: Lélia Gonzales (2020), Beatriz Nascimento (1995), bell hooks (2017) ${ }^{1}$ e Audre Lorde (2019), principalmente, mas não exclusivamente. Debruçamo-nos sobre as teóricas do feminismo negro porque pautam direitos para maiorias minorizadas em função da condição de raça, gênero e todos os múltiplos fenômenos que cercam o constituir -se pessoa fora do "padrão" em qualquer tempo. O outro do outro, conforme a definição de Simone de Beauvoir².

Feitas as devidas apresentações e contextualizações, é necessário explicar como está organizado o texto: ancora-se em uma perspectiva crítica sobre o feminismo negro como estratégia para pautar temas "espinhosos" ao processo de formação de professoras para os anos iniciais. O combate ao racismo e o sexismo que circundam a vida e as rotinas das meninas pretas e seus processos de resistência a partir da escola de educação básica: as dores, o preterimento, as ausências e falta de representatividade e acolhimento que

1 Pseudônimo da professora, escritora e poeta Gloria Jean Waltkins. Ressalte-se que o pseudônimo é sempre grafado e minúsculo para que a identidade da acadêmica não fique maior do que a da ser vivente Glória.

2 Beauvoir entende que na visão do conhecimento ocidental sexista a mulher (branca) é "o outro' do sujeito universal (o homem branco). Nesta perspectiva, tudo que não cabe no conceito é "outro do outro", logo não tem espaço no sistema hierarquizado na supremacia branco e heteronormativa. 
faz que se configure na escola os primeiros movimentos de acomodar-se em papéis de subalternidade para poder existir.

$\mathrm{Na}$ primeira parte, desenvolvemos uma proposta inspirada nos textos de Beatriz Nascimento (1995) sobre as memórias que parecem gravadas no DNA do povo preto: o despertar durante a travessia no Atlântico e as consequências trazidas por um processo de apagamento/silenciamento que faz com que a história e cultura do povo preto esteja ausente dos currículos escolares, e, portanto, subentendido como não importante. Os impactos da travessia no Atlântico, na incerteza do destino na América, se reproduzem na escola de educação básica em materiais didáticos que ignoram/desvirtuam a história e memória do povo preto, no preterimento das meninas pretas nas brincadeiras, jogos, participação, vivência e atividades escolares.

Debatemos sobre o engodo do processo de universalização que permitiu estar na escola, mas, não viver a escola como pressuposto para acessar espaços de cidadania, que nunca se concluem de fato para as meninas pretas. Dialogamos sobre os impactos do racismo, sexismo e sobre a ausência de políticas públicas para reparação e inclusão para participação e ocupação de espaços de poder e decisão. $\mathrm{Na}$ segunda parte, reportamo-nos a teoria produzida pelas intelectuais pretas e dos contextos em que foram produzidos seus estudos e se houve (ou não) avanços quando se analisam as narrativas das meninas pretas de suas vivências escolares. Por fim, em função da limitação que as páginas impõem para compartilhamento, fazemos um confronto entre a teoria e as narrativas produzidas no processo de escuta ocorrido durante o acompanhar (por vídeoaula sempre que possível e produção de vídeos depoimentos das meninas) e apresentamos nossas considerações neste movimento inicial durante esse primeiro ano de desenvolvimento do estudo.

Sem intenção de ser um texto acabado, apresenta-se como seminal a ser acrescido na medida em que a pesquisa continua e avança. Mas, como resultados até o momento, fica fortalecida a percepção de que as meninas pretas resistem ao processo de apagamento e traçam caminhos de protagonismo na escola, muito mais em virtude dos saberes ancestrais reforçados por comunidades femininas de lideranças pretas, do que por processos de inclusão oportunizados pela escola. 


\section{Dias de luta sem glória: como e porque a travessia do Atlântico é sempre inacabada}

Ao analisarmos as vivências e as experiências que nos fazem ser quem somos e nos mostram o quê, como e onde podemos ressignificá-las, nos deparamos com uma bagagem de histórias que fortalecem e reconfiguram esse percurso de modificação de ideias, perspectivas, posicionamentos e argumentos, em relação a existência e resistência do povo preto, temática a que vimos nos dedicando nos últimos três anos em nossos estudos e pesquisas.

[...] O feminismo negro possui sua diferença específica em face do ocidental: a solidariedade, fundada em uma experiência histórica comum. Por isso mesmo, após sua reunião, aquelas mulheres - Beatriz, Marlene, Vera, Mara, Joana, Alba, Stella, Lucia, Norma, Zumba, Alzira, Lísia e várias outras (eram cerca de vinte) - juntavam-se a seus companheiros para a reunião ampliada (que chamavam de Grupão) onde colocavam os resultados de sua discussão anterior a fim de que o conjunto refletisse sobre a condição das mulheres negras (Gonzales, 2020, p. 109).

O feminismo negro surge como contraponto a um movimento que não parecia ter intenção de acolher para além dos dilemas e contradições das mulheres brancas de classe média que debatiam durante as tardes em suas reuniões de reflexões e digressões, enquanto suas empregadas pretas cuidavam das suas crianças, preparavam os jantares para alimentar seus maridos e limpavam suas casas. Nas longas discussões sobre as categorias do marxismo nunca pararam um minuto para refletir sobre o fato de que certos/certas trabalhadoras são invisíveis até para as categorias de trabalho/trabalhadores. E, sem pautar as especificidades de como a raça estrutura os impactos das vivências não se pode sugerir igualdade. Como alternativa ao marxismo que não nos contempla, escolhemos estruturar a pesquisa sobre os pressupostos do matriarcado africano: o feminino, a resistência e a força.

Entretanto, trazer as memórias de nossas e nossos ancestrais pretos e pretas, como referência para explicar e explicitar as lutas que o povo preto tem 
enfrentado e travado, é também remexer em lutas não acabadas para existir para além dos espaços de subalternidade: o dia 14 de maio de 1888 nos trouxe uma "liberdade" cilada, porque não veio acompanhada de terras, emprego, profissionalização e letramento que nos permitisse entender e interpretar as palavras do novo continente para ler o mundo.

$\mathrm{O}$ mundo que nos foi apresentado foi um mundo que havia expropriado o povo preto daquilo que mais fundamental existe na vida da pessoa humana: a memória, a história e o sentido de pertencimento. Nossa ancestralidade era motivo de vergonha por não caber na "normalidade" de um povo que, sendo mestiço, se pretendia eurocêntrico. Os turbantes, as curvas do corpo, as letras carregadas, a musicalidade, a fé e os dogmas foram criminalizados. $\mathrm{O}$ acesso à escola e à educação formal, de certa forma, nos foi proibido, negado. Primeiro em função da necessidade de sobrevivência e, depois, em face do ordenamento jurídico.

As palavras da escritora e pesquisadora bell hooks (2017, p.12) parecem terem sidas escritas a luz das contradições da abolição que, ao invés de libertar, limitou as existências pretas:

De repente, o conhecimento passou a se resumir a pura informação. Não tinha relação com o modo de viver e se comportar. Já não tinha ligação com a luta antirracista. Levados de ônibus a escolas de brancos, logo aprendemos que o que era esperado de nós era a obediência, não o desejo de aprender. A excessiva ânsia de aprender era facilmente entendida como uma ameaça a autoridade branca.

Nunca é demais retomar que o ordenamento jurídico brasileiro, desde o primeiro momento, discriminou e criminalizou a memória, a história e a cultura do povo preto: a primeira lei de educação (1837) proibiu as pessoas pretas de frequentarem a escola, ainda que fossem livres. Em 1850, a Lei de Terras proibiu que pessoas pretas tivessem terras: não podemos esquecer que os pretos africanos detiveram durante muito tempo o conhecimento sobre a tecnologia agrícola ainda desconhecido pelos portugueses, no século XVI, com a expansão das fazendas de cana de açúcar e, por comodismo e arrogância, em ato contí- 
nuo durante todo período que se seguiu até a "abolição" em $1888^{3}$. Era preciso impedir que o acesso à terra permitisse que eles ficassem de fato emancipados e não se sujeitassem mais a fazer qualquer trabalho por qualquer pagamento.

As Leis que antecederam a Lei Áurea foram no sentido de perpetuar a escravidão sobre novas formas e descartar as "peças" que não correspondiam a "produtividade" esperada. Por fim, a Lei da Vadiagem de 1890 concedia ao estado brasileiro o direito de encarcerar capoeiristas, músicos e quaisquer pessoas que estivessem perambulando pelas ruas, sem trabalho ou residência comprovada. Da mesma maneira, os que estivessem portando objetos relativos à capoeira, conforme o Código Penal - Decreto no 847, de 11 de outubro de 1890 (atenção, 2 anos depois da abolição).

A partir da Constituição Cidadã (1988), no período que se seguiu ao final da ditadura militar e início dos processos de redemocratização dos espaços, era esperado que essas assimetrias fossem sendo equalizadas a partir de políticas públicas que pudessem, de maneira planejadas e sistemática, incluir de fato e de direito todas as crianças em processos de aprender e viver a escola. Para além dos exercícios de memorização, a proposta era leis que organizassem o ambiente escolar para que durante a educação básica houvesse a transição de estudantes para cidadãos/cidadãs. Articulado a políticas públicas que tinham intenção de defender a educação pública, laica e de qualidade para todos e todas, um referencial curricular de formação de professoras que reconhecessem assimetrias, injustiças e incoerências, contribuísse para organização da sociedade com igualdade de oportunidades a partir de espaços educacionais.

Foi assim que os primeiros anos do novo milênio se anunciaram as brasileiras que não se viam para além dos espaços de subalternidade: como tempos de esperança de serem escolhidas logo para as brincadeiras, de carregarem a bolsa da professora, de escolherem papéis a serem interpretados nas escolas e na vida, de receberem abraços e não estarem escondidas nas fotos de turma porque os

3 A escravização de indígenas encontrava na igreja católica forte oposição considerando que eram alvos potenciais de evangelização. As feitorias de Portugal na Costa Africana serviram, portanto, a cessão de "peças" para o trabalho na lavoura por dois motivos: dominavam a tecnologia para potencializar a plantação de cana de açúcar e a mitologia africana se confrontava com a mitologia católica cristã levando os jesuítas a defenderem que o povo preto "não possuía alma" 
cabelos não estão "ajeitados” o suficiente. De não serem mais desencorajadas em seleções para escolas de balé. Não serem silenciadas nas salas de aula e estarem nas listas de as mais bonitas da escola em murais de festa das Nações, que até hoje não contemplam o continente africano em toda a sua diversidade.

Não aconteceu. Livros didáticos continuam apagando as histórias, memórias e ancestralidade do povo preto. Quando aparecem são por meio de "arte" de gosto duvidoso exaltando torturas contra corpos pretos. Ou, exaltando o "folclore" da religiosidade. Reafirmando por meio de mensagens subliminares que nem todas as mulheres podem ocupar os lugares que queiram: alguém precisa limpar, arrumar, cuidar das crianças e servir o almoço enquanto outras escrevem, refletem e debatem os grandes temas da academia. Há mais de quinhentos anos os corpos excluídos deste poder de escolha e decisão são pretos.

\section{Mantendo a coragem alimentada: tecendo resistência a partir do conhecimento}

Mover-se em disparate a algo é necessariamente um processo de "desacomodação" daquilo que performamos como pensamento mutável. A estrutura da Academia Contemporânea não-generalizada, e aqui abarco ela em todas as suas características, desde a oportunidade de acesso que é oferecida a quem recorre aos estudos realizados a partir dos espaços acadêmicos até ao tripé da Universidade (Ensino, Pesquisa e Extensão), é totalmente formulada, ainda, pela perspectiva cis-hetero-patriarcal, racista e cisnormativa.

As discussões das feministas negras a partir da Interseccionalidade empenham-se em desacomodar as nossas opiniões e produções para que tenhamos senso de percepções e compreensões dos movimentos e das estruturas que regem e articulam as produções de desigualdade de oportunidades nos processos de ascensão das mulheres pretas, dos povos tradicionais, das dissidências sexuais e das diferentes formas de performatizações de existência, ou seja, como hooks (expõe 2017, p. 67):

Inicialmente, nos movimentos feministas, mulheres brancas com alto nível de educação e origem na classe trabalhadora eram mais visíveis do que mulheres negras de todas as classes. Elas eram minoria dentro dos 
movimentos, mas a voz da experiência era a delas. Elas conheciam melhor do que suas companheiras com privilégios de classe, de qualquer raça, os custos da resistência à dominação de raça. Classe e gênero. Elas sabiam o que significava lutar para mudar a situação econômica de alguém. Havia conflito entre elas e suas companheiras privilegiadas sobre comportamento apropriado, sobre questões que seriam apresentadas como preocupações feministas fundamentais.

Para a compreensão do que bell hooks (2017) expõe em diálogo com as pesquisadoras que a antecederam no debate sobre feminismo e feminismo negro, é necessário revermos a que nos propusemos e nos significados que se colocam a partir dos lugares de onde pautamos nossas narrativas: a escola de educação básica em sua formação continuada e os cursos de licenciaturas das Universidades Públicas no processo de formação inicial durante a fase de incertezas no início do isolamento social da COVID-19.

Os saberes acadêmicos mostraram-se ineficientes para lidar com um fenômeno que não havia sido pautado nos tratados e estudos das ciências da educação: não havia hipóteses construídas para as formas como a educação a distância poderia ser utilizada em um momento de catástrofe e caos que vivenciamos. Por outro lado, os saberes produzidos na urgência e emergência da necessidade de respostas rápidas articulados com a produção disponível para ensino remoto, produziram algumas respostas que, naquele momento, esperançaram professoras e acadêmicas que se propuseram a trabalhar juntas.

Foram 13 professoras e 08 acadêmicos que estudaram juntos, organizaram propostas e viabilizaram que as comunidades escolares se mantivessem alimentadas para nutrir a alma, o corpo e a esperança.

Assim sendo, a investigação pautou-se sobre de que maneira a intersecção raça e gênero interfere no percurso escolar das meninas pretas na escola dos anos iniciais em uma escola que não as vê: como se dividem as oportunidades? Como se organiza o sistema de meritocracia diante de oportunidades diferentes para existências subalternizadas? A Escola pública emancipadora é para todas as crianças? Como está organizado o material didático? Quem são 
as crianças protagonistas de festas, eventos, diálogos e brincadeiras na escola? Partindo de pontos diferentes, é possível atingir/alcançar os mesmos espaços?

Os Estudos Interseccionais nos permitem transitar e reconhecer as vias de opressões e de que forma elas operam sobre o processo de escolarização de meninas pretas. E não seria plausível identificar estas opressões de forma ordenada e somada, pelo contrário. Por esse viés, nos alinhamos ao pensamento de Audre Lorde: não há hierarquia de opressões, a "bicha preta" não sofre mais ou menos que a menina preta. Ela sofre, e, as marcas do sofrimento se fazem notar em cada movimento e busca de ser reconhecida em sua singularidade.

Não existem hierarquias quando se trata de se sentir os efeitos das ausências, do imobilismo que leva a subalternização, na conformidade com a existência por falta de tecnologia que alimente a resistência. Desta maneira, meninas pretas têm vivido a margem e continuam ocupando os últimos lugares em quaisquer estatísticas que se faça para mapear ocupação de espaço e assunção a subalternidade: nesta escola, majoritariamente constituída de meninas pretas, nunca houve uma noiva da quadrilha da festa junina preta. Nunca houve uma miss Feira das Nações Preta. Nenhum livro didático traz a história de Tereza de Benguela (que organizou uma escola de ensinar as primeiras letras em Quariterê), de Dandara, de Carolina de Jesus. Não há uma única professora preta entre o corpo docente. As mulheres pretas da escola estão fazendo os serviços que ninguém quer fazer: limpando os banheiros. Servindo as outras mulheres. Esperando e cuidando.

Aquelas entre nós que estão fora do círculo do que a sociedade julga como mulheres aceitáveis, aquelas de nós forjadas nos cadinhos da diferença aquelas de nós que são pobres, que são lésbicas, que são negras, que são mais velhas, sabem que a sobrevivência não é uma habilidade acadêmica: essa é sem dúvida a primeira lição que aprendemos em nossos percursos de escolarização (Lorde, 2019, p. 137).

Somos a resistência e temos de nos acomodar para avançar. As meninas aceitam papéis de cuidar, de ser a empregada, de ser a que corre para pegar, a que procura o amigo escondido. Crianças querem brincar, fazer parte. E, pela 
falta de discussão das ausências presentes na escola em seus anos iniciais nos processos de formação, se vai naturalizando que garotas pretas exerçam determinados papéis. As meninas vão sendo educadas para ficar menor para caber. Não para deixar os espaços maiores para que todos e todas possam caber. E, quando fortalecidas pelo aquilombamento ${ }^{4}$ (movimento que se fortaleceu a partir dos anos de 2015) somos consideradas violentas, grosseiras, mal educadas. $\mathrm{O}$ mundo se acostumou a ver a mulher preta subalternizada. Difícil se acostumar com vozes que se levantam a favor de direitos estendidos. Aquilombamo-nos para não estar só, não ser mais a impopular e até hostilizada, e a unir forças com outras que também se identifiquem como estando de fora das estruturas vigentes para definir e buscar um mundo em que todas possamos florescer. Reafirmamos em nossa ação ativista o pensamento de Audre Lorde (2019, p. 137) “[...] as ferramentas do senhor nunca derrubarão a casa grande. Elas podem possibilitar que os vençamos em seu próprio jogo durante certo tempo, mas, nunca permitirão que provoquemos uma mudança autêntica”. Não vamos nos conformar, mas, temos de criar outras estratégias para proteger e fortalecer nossas meninas pretas.

Assim, entendemos as "concessões" efetivadas ao longo da última década como ações estrategicamente viabilizadas para manter tudo como sempre esteve: a intenção de tornar a educação básica universalizada um laboratório a favor da cidadania estendida se mostrou muito aquém da boa intenção externada. Ao final, o que se tem nos sistemas educacionais públicos hoje são as crianças para quem é natural aprender e viver a escola e, no outro extremo, crianças sem o direito de serem reconhecidas como crianças. A escola em seus anos iniciais ainda é um lugar do privilégio branco de crianças que durante o período mais duro da pandemia puderam estar protegidas e alimentadas (nesta

${ }_{4} \mathrm{O}$ conceito de aquilombamento tem a ver com a força dos Quilombos espaços de resistência contra o apagamento e silenciamento do povo preto, bem como, experimentação de novas formas de pensar e sistematizar a organização política tendo como ponto focal a equidade, parceria entre homens e mulheres nos espaços de decisões. Isso posto, vale em uma apropriação do conceito para o fato de que quando mulheres pretas se juntam em um processo de empoderamento estão praticando o aquilombamento: se juntar em torno de um objetivo comum promover a ocupação de mulheres pretas em espaços de poder e decisão para favorecer a verdadeira emancipação: do e pelo conhecimento. 
escola uma minoria) e outras que perderam (inclusive) o único espaço em que poderiam exercer parte de seu direito à infância.

Analisamos não apenas o racismo que ali operou, mas também o sexismo, ou seja, entrecruzou-se não apenas a questão de raça como uma unidade apenas, mas percebe-se que junto a este fato também operam outras matrizes de opressões, e que são estas que acabam sendo refletidas no percurso de muitos pretos e principalmente da criança preta (Oliveira, 2017).

A partir do entendimento ampliado sobre o significado destes movimentos do Oceano Atlântico com o tráfico negreiro com a carga de suor, lágrimas, desesperança e sofrimento que veio junto ao povo preto, constatamos como as matrizes das opressões estão a todo momento operando não para imobilizar, mas para a derrocada do povo preto em sua emancipação, mas não podemos esquecer que "[...] a diáspora negra deu suor, lágrimas e sangue ao gosto do Mar" (AKOTIRENE, 2019, p. 42). Logo, é a necessidade de que essas matrizes de opressão sejam desmontadas que impulsionam a luta por um mundo mais equânime de afetos, conhecimentos e vidas múltiplas.

Junto aos estudos desenvolvidos a partir do estudo da Interseccionalidade, analisamos também as questões relativas a academia - Legislações para a política de inclusão e permanência da população preta nas instituições educacionais- aspectos que ainda são realizados de maneira pouco visível e que tornam-se efetivos para o processo de exclusão e inserção de pessoas pretas, LGBTQIA+ e mulheres pretas na consolidação de um pressuposto de quem deve e quem não deve participar das estruturas, fortalecendo e reiterando a ideia de que uma educação colonialista serve a todas as pessoas.

\section{Sobre as herdeiras da travessia no Atlântico: feminilizar o movimento ne- gro e enegrecer o movimento feminista}

Vamos pautar a análise de três situações selecionadas especificamente nos estudos da Professora Sueli Carneiro (2019), que chama atenção para o fato de que é preciso ter mais mulheres nas lideranças executivas do movimento negro e mais mulheres pretas pautando ao movimento feminista, para 
se atingir e dar visibilidade ao movimento de resistência e resiliência que as meninas pretas precisam exercer ao longo da vida para ter o direito de existir.

Torna-se fundamental explicitar que a escola em questão se localiza no extremo leste da periferia de Porto Velho, capital de Rondônia, em um bairro em que a maior parte das casas segue a estética do "puxadinho": casas em que os cômodos vão sendo acrescidos na medida em que a família vai ganhando dinheiro e adaptando a casa ao número de habitantes. Poucas ruas têm asfalto. A escola tem 10 salas de aula, uma sala de recursos, sala da direção, refeitório, cozinha, sala de leitura (com grande parte do acervo de livros didáticos) e sala da coordenadora pedagógica. No processo em que os/as estudantes do Curso de Pedagogia participaram para fomentar estratégias para o ensino remoto participaram 13 professoras e seis estudantes, nos processos de um curso de formação realizado por via Google Meet. Registre-se que mesmo as professoras tiveram dificuldade de acessar a tecnologia para os encontros virtuais, seja pela inconstância da rede ou pela falta de aparelhagem para conduzir e acompanhar a formação.

Para atendimento das questões que norteiam essa produção, a discussão centrar-se-á em como são inseridas nas rotinas das meninas pretas as especificidades de existir para fora do "padrão" ditada pelas representações da criança universal. As cenas inspiradas na etnografia escolar e da autoetnografia abordam principalmente as falas e ações dos professores, sem deixar de lado os aspectos necessariamente relacionais das questões como máximas simplificadoras em relação ao racismo, interseccionalidade, representações sobre a infância e sobre a ocupação de postos de poder por mulheres pretas.

No processo de formação para o ensino remoto, debatemos com as professoras três questões centrais: ensino remoto e seu significado, livro didático e quem são nossos alunos e como se situam no contexto de uma pandemia que não tinha (tem) prazo para acabar em solo brasileiro, considerando a desorganização das políticas de acolhimento e cuidados com a população vulnerável (e preta) do lugar/espaço.

Primeiro espanto para o grupo de acadêmicas: as professoras não percebiam a relação entre a pobreza quase indigente das alunas daquele lugar espaço com o fato de as famílias dessas meninas serem constituída majoritariamente por 
mulheres pretas em condições de extrema vulnerabilidade (sem trabalho formal, com baixa escolaridade e desempregadas), que tinham como prioridade absoluta oferecer pelo menos uma refeição aos membros da família. Diante de tal situação e realidade, a escola era um ponto de garantia para assegurar um kit de alimentação para dez dias e menos lugar de esperançar por meio do conhecimento.

Com relação à pergunta sobre se notavam algum texto/contexto que as incomodava nos livros didáticos, em torno dos quais se organizavam as rotinas didáticos pedagógicas, as professoras responderam que não viam nenhuma anormalidade em livros que só traziam uma versão da história, não apresentava figuras das famílias brasileiras em todas suas diversidades, e em que se pese a legislação que orienta o Programa Nacional do Livro Didático, apresentava o tráfico de pessoas como "comércio" entre a Inglaterra e o Brasil. Sem problematizar os significados deste movimento até hoje para as pessoas pretas.

$\mathrm{Na}$ escola com noventa e cinco por cento de crianças pretas (456 crianças), ser branca, ter cabelo liso e ser identificada como "bonita" garante espaços de protagonistas em festas e, agora, vídeos de trabalho pedagógico disponibilizados pelas professoras. As meninas pretas quase não aparecem por não disporem da tecnologia necessária e, quando dispunham, por não se enquadrarem no "padrão" de beleza estético "naturalizado" pela ausência: sem eufemismo, não são consideradas bonitas.

Por fim, quando confrontadas com os sentimentos sobre suas alunas pretas em meio a uma sociedade que não assume seu racismo estrutural se escondendo atrás do mito da democracia racial e da meritocracia (que tem cor e classe no Brasil), os sentimentos se misturam e se transmutam em desejo que eles possam superar o determinismo e vencer o estigma do pobre, preto e marginal. $\mathrm{O}$ discurso mistura concepções pedagógicas, religiosas e de um arremedo de revolta e tristeza. Nesta mistura antropológica estão suas crenças protestantes, suas esperanças de professoras e seu desalento de mulher pobre:

[...] As crianças não tem separação não. Tão interessados em leitura, livros e histórias. As meninas querem ser iguais às modelos, as atrizes. Mas, isso é igual para menina morena e menina branca. Aqui não se tem sonhos de 
grandeza: as crianças querem ter a comida no prato todo o dia. $\mathrm{O}$ sonho delas é trabalhar no ar (condicionado). As mães estão sempre muito ocupadas, cansadas e não conseguem vir a escola quando a gente chama. Agora, está uma dificuldade de comunicação. Tem mãe que não consegue nem vir na escola (sic) buscar a tarefa. Como é que aprende preocupada com a fome, com a falta de trabalho? (ML, professora, 2020).

A ação de alfabetizadora está diretamente ligada às dificuldades de ser professora em um ambiente tão inóspito quanto o vivenciado pelas famílias pobres. A leitura de mundo mistura opressão a ser superada, desencanto com os espaços por onde transitam e esperança em um futuro que parece não chegar. Como acreditar em liberdade em lugares que negam aos indivíduos o direito de assumir sua identidade étnica, sua ancestralidade? A conquista da liberdade e da autonomia no exercício da docência deveria ser sempre dialógica, com superação dos preconceitos e da opressão.

\section{Considerações finais: conversas de pret@s}

Chegamos a esse ponto ousando discordar de bell hooks: para as meninas pretas na escola de educação básica não é permitido fazer perguntas constrangedoras. Não é permitido ter desejos de protagonismos e escolhas na própria vida. Para essas meninas o silenciamento, o apagamento e a resignação a vida possível parece ser a regra. Se ousam discordar são rotuladas como insurgentes e arrogantes e "evadidas" dos espaços escolares. Se ousam sonhar com espaços de visibilidade, são ridicularizadas em um processo que só constrange a elas e suas famílias.

Para confrontar preconceitos e discriminações é preciso uma educação para transgredir e atuar para desorganizar os pressupostos sobre a intrínseca vinculação entre raça, gênero, classe, sexualidade e nacionalidade. Implica também perceber que toda educação (escolar, familiar, religiosa etc.) em que se pese a instituição na qual ocorre é resultado da sociedade que a circunda. Uma sociedade racista, sexista e classista não produzirá educação antirracista e cidadã. 
A educação precisa se atentar às assimetrias que exigem, por sua vez, políticas para reconhecimento que existem identidades, estão subalternizadas e precisam ascender com protagonismo, alteridade e escolhas, além de um efetivo esforço para "desnaturalizar" o currículo do sujeito universal: faz-se necessário transversalizar conteúdos e métodos. Desse modo, é possível por exemplo, aprender geometria, história, geografia, artes, física e biologia jogando capoeira; ou aprender criticamente sobre história, política, filosofia, globalização e literatura se apropriando da literatura das escritoras pretas como Carolina de Jesus, Conceição Evaristo, Lima Barreto, Elisa Lucinda, blogs ou um romance de Paulina Chiziane. Ou, ainda refletir sobre processos de cura, linhagens femininas e sacralização da natureza por meio do sagrado das religiões de matriz indígena ou africana.

Nós também buscamos a teoria da interseccionalidade em uma tentativa dolorida de encontrar caminhos que nos permitissem criar estratégias e perfilar de fato uma educação para todas e todos. Não foi por acaso que a constituição cidadã trazia, em muitos artigos ratificados depois pela Lei de Diretrizes e Bases, a importância de uma educação básica fortalecida e comprometida com o desenvolvimento da cidadania ativa: o respeito a diversidade, o conhecimento para igualdade de oportunidades e justiça no exercício de direitos e compartilhamento de deveres é a base das sociedades desenvolvidas e democráticas. Não se pode excluir pessoas da vivência plena por não terem a "cor" certa. Não se pode determinar por meio do livro didático qual história deve ser contada e quais crianças não terão acesso a sua própria história. Não se deve hierarquizar culturas: são traduções de vivências e memórias diferentes e não melhores ou piores.

Como professor@s que somos não podemos mais conviver com os maus-tratos a infância para além do sujeito universal: não reconhecer a humanidade, a beleza, a força da memória da ancestralidade é machucar crianças que não se sentem parte, pertencendo a um não lugar. Obriga-las a se apequenar e negar suas características para acessar brincadeira e direito a voz não é só cruel: é desumano. $\mathrm{O}$ mergulho na teoria da interseccionalidade nos permitiu perceber o quanto a caneta do gestor não realiza ação pedagógica emancipadora. 
A convivência com as crianças pretas de uma escola em que são maioria e não estão presentes no currículo foi uma provocação e um alerta: a educação emancipadora e cidadã presente nos documentos que regulam processos educativos desde a redemocratização não são para todas as crianças.

Assim como bell hooks, nossos esforços de compreensão da teoria a favor de uma prática se estruturam em torno da necessidade de que as palavras se tornam mais significativas quando contribuem para o engajamento em um processo que incluas mais pessoas na transgressão para ser livre sem deixar de se comprometer com os avanços coletivos.

A teoria do feminismo negro organizada em torno do matriarcado africano e do aquilombamento para o combate a solidão nos capacita, e, nos tornando mais fortes enquanto professor@s, nos organiza para um ativismo que tem intenção de mudar ao estabelecido para romper com a educação colonial, sexista e machista. A educação antirracista e transgressora é também uma educação de combate à violência doméstica, de respeito as muitas formas de existir no mundo e nos vários sinônimos que o amor pode ter. A educação como prática de liberdade é estabelecida em práticas que contribuam para fazer escolhas e assumir as consequências.

A educação como prática de liberdade ainda não é para todas as pessoas. Mas, precisa ser. Porque senão, todos os esforços para organização de uma educação para a cidadania será mais uma utopia que não se configurou em ações concretas para entregar um mundo mais humano, inclusivo e plural em legado as próximas gerações.

\section{Referências}

AKOTIRENE, Carla. Interseccionalidade. São Paulo: Sueli Carneiro; Pólen, 2019.

CAETANO, Márcio; LIMA, Carlos Henrique L; CASTRO, Amanda M. Diversidade sexual, gênero e sexualidades: temas importantes à educação democrática. In: Colloquium Humanarum, Presidente Prudente, v. 16, n. 3, p.516 jul/set 2019. DOI: 10.5747/ch.2019.v16. 3. 
CARNEIRO, Sueli. Escritos de uma vida. São Paulo: Pólen. Livros, 2019.

DAVIS, Angela. Mulheres, raça e classe. Tradução de Heci Regina. Candiani. São Paulo: Boitempo, 2016.

GONZALES, Lélia. Por um feminismo afro-latino americano. Ensaios, intervenções e diálogos. Org. Flávia Rios e Márcia Lima. Rio de Janeiro: Zahar, 2020.

GROSFOGUEL, Ramon. Para descolonizar os estudos de economia politica e os estudos pós-coloniais: Transmodernidade, pensamento de fronteira e colonialidade global. Revista Critica de Ciências Sociais, 2008.

HILÁRIO, Rosangela A. O feminismo como estratégia de ascensão a mulheres pretas e periféricas. Revista Ensaio Filosóficos, 2019, p. 40-58.

hooks, bell. Ensinando a transgredir. A educação como prática de liberdade. 2. ed. Tradução de Marcelo Brandão Cippola. São Paulo: Martins Fontes 2017.

LORDE, Audre. Irmã Outsider. Ensaios e conferências. Tradução Stephanie Borges. Belo Horizonte: Autêntica, 2019.

LORDE, Audre. Idade, raça, classe e gênero: mulheres redefinindo a diferença. In: HOLLANDA, Heloisa Buarque (org.). Pensamentos feministas: conceitos fundamentais. Rio de Janeiro: Bazar do Tempo, 2019.

MALDONADO-TORRES, Nelson. "Sobre la colonialidad del ser: contribuciones al desarrollo de un concepto", em CASTRO-GÓMEZ, Santiago \& GROSFOGUEL, Ramon (coords.) E1 giro decolonial: reflexiones para uma diversidad epistêmica más allá del capitalismo global. Bogotá: Siglo del Hombre Editores; Universidad Central, Instituto de Estudios Sociales Contemporáneos, Pontificia Universidad Javeriana, Instituto Pensar, 2007.

NASCIMENTO, Maria Beatriz. Culturalismo e contracultura. In: Cadernos de Formação Sobre a Contribuição do Negro na Formação Brasileira. Niterói, ICHF-UFF, 1976, p. 02-06. 
OLIVEIRA, Megg Rayara Gomes de. O diabo em forma de gente: (r)existências de gays afeminados, viados e bichas pretas na educação. Tese (Doutorado em Educação). Programa de Pós-Graduação em Educação da Universidade Federal do Paraná. UFPR, Curitiba, 2017. Disponível em: https://acervodigital.ufpr.br/handle/1884/47605. Acesso: 21 de mar. 2021. 


\section{EDUCAÇÃO RIBEIRINHA E REFLEXÃO DA PRÁ- TICA AMBIENTAL NO CONTEXTO AMAZÔNICO DE PORTO VELHO, RO}

Berenice Perpetua Simão

Clarides Henrich de Barba

Fábio Santos de Andrade

\section{Introdução}

Remanescentes dos antigos seringais do século XIX, as comunidades da região do Baixo Rio Madeira, Porto Velho (RO), vivem os maiores impactos sócio ambientais, culturais impostos pelo desenvolvimento econômico e, principalmente nas últimas décadas, vem se agravando com a exploração dos recursos naturais de mineração, com o desmatamento em função da extração de madeiras, com a expansão da fronteira agropecuária e da cultura da soja, e, mais recentemente com implantação das grandes hidrelétricas sobre o Rio Madeira (Cavalcante, et al, 2011, p. 8).

O cotidiano dos ribeirinhos dessa região é marcado pela extração de produtos da floresta (açaí, pupunha, castanha, pescado), pequenas agriculturas de várzea ou roças, produção artesanal de farinha de mandioca, além do subemprego na extração do ouro e madeira. A convivência de interação social compreende a participação da comunidade nas atividades escolares de ensino básico, eventos religiosos, festejos tradicionais e jogos de futebol (Rezende, 2010).

Entende-se que conhecer as pessoas, seus espaços físicos, bem como as atividades laborais, socioculturais e históricos de vida dos moradores de uma região é primordial para se iniciar a aplicação de um projeto de pesquisa em educação, principalmente por se tratar de comunidades com hábitos, costumes e atividades laborais bem diferentes do cotidiano urbano e acadêmico.

Nesse sentido, organizou-se dentro da revisão de literatura uma reflexão a partir das leituras dos autores para responder questão de "Por onde começar 
o planejamento de conteúdos em Educação Ambiental (EA) para educação básica em escolas ribeirinhas?"

Este trabalho tem como objetivo fazer uma reflexão prévia sobre o lugar e espaço ribeirinho, bem como do modo de vida das pessoas que nele convive para que o planejamento das ações que se pretende em EA considerem a cultura e vivências de toda a comunidade escolar.

Sendo assim, este artigo apresenta uma revisão de literatura, dentro da metodologia bibliográfica (Gil, 2002), a luz dos autores Ariés (2006), Augé (2012), Candau (2008), Certeau (2011), Freire (2002), Giddens (1991) e Merleau-Ponty (2011) em estudos realizados na disciplina Educação Escolar: história, organização, diferenças culturais e interculturalidades em dezembro de 2020, no Curso de Doutorado Profissional em Educação Escolar - PPGEEProf., da Universidade Federal de Rondônia. Ao final da disciplina, os autores (doutoranda e professores do curso) propuseram uma reflexão a partir dos referidos autores para uma melhor compreensão dos lugares (comunidades ribeirinhas) e das pessoas onde se pretende aplicar um projeto de pesquisa em EA.

Buscou-se, também, neste trabalho, ousar um olhar da Fenomenologia para "[...] desvendar o mundo percebido e vivido dos estudantes e dos professores referente ao meio ambiente, o espaço e o território ribeirinho" (Barba; Lima; Nobre, 2020, p. 212).

\section{Educação: a escola como reflexo do lugar real onde se vive}

O papel da educação, bem como da pesquisa científica, em quaisquer lugares que se efetivem, tem sempre a responsabilidade de promover o conhecimento para melhoria das pessoas e, consequentemente, contribuir para o desenvolvimento dos lugares onde essas atuam. No entanto, para que isso aconteça é necessário integrar o lugar, espaço, tempo e atividades socioculturais onde os alunos convivem, para que estes sintam a educação e os conhecimentos escolares e científicos integrados aos contextos socioeconômicos e culturais de onde moram. A escola necessita ser o reflexo do ambiente de vivência dos alunos, deve interagir com os saberes locais buscando sempre a interação so- 
cial, o conhecimento de mundo e, consequentemente, ofertar aos alunos um acolhimento humanizado.

Uma vez que "Ensinar exige pesquisa" (Freire, 2002, p. 14), nada mais coerente do que propor melhorias na educação para a região através da pesquisa e, dentro da pedagogia crítica, buscar a reflexão sobre a prática (Saviani, 2005; 2007). Defende-se neste trabalho que tanto a pesquisa quanto as propostas educacionais adotem uma linha onde "[a] reflexão crítica sobre a prática se torna uma exigência da relação Teoria/Prática sem a qual a teoria pode ir virando blablablá e a prática, ativismo" (Freire, 2002, p. 12).

Desta forma, propõe-se que uma das reflexões críticas a ser observada é justamente a necessidade de, cada vez mais, entrelaçar os conteúdos escolares com temas do cotidiano de trabalho e vivência dentro dos espaços onde a escola atua. Em se tratando dos espaços amazônicos, esta atitude objetiva dar um sentido, ou, pelo menos, proporcionar que professores e alunos pensem e reflitam sobre a vivência dentro da floresta, caso contrário, a escola não passará de mera reprodutora dos conhecimentos colonizadores existentes no Brasil, desde o início da colonização europeia.

Candau (2008, p. 33) assim se manifesta sobre esta discussão, para o autor, "[a] escola como instituição está construída tendo por base afirmação de conhecimentos considerados universais, uma universalidade muitas vezes formal que, se aprofundarmos um pouco, termina por estar assentada na cultura ocidental europeia, considerada como portadora da universalidade".

É comum professores e pais aconselharem alunos e filhos dizendo que através dos estudos se conquista uma vida melhor, fato que pode ser real, mas, se essa vida melhor for cursar o ensino superior e ter uma profissão digna para os jovens, a escola deveria ter também uma abordagem de envolvimento com as atividades laborais das comunidades em espaços de florestas e rios. Deste modo, essa é uma ação local importantíssima a ser executada para que os alunos sintam a escola também como o seu lugar para crescer, curtir sua juventude e construir seu futuro. No entanto, para que isso aconteça, a escola como um todo necessita refletir, planejar e proporcionar um espaço de identidade local que valorize a sociedade ribeirinha. 
Essa valorização envolve um olhar especial tal como Barba, Lima e Nobre (2020, p. 214) descrevem as escolas ribeirinhas em Porto Velho:

As características de uma escola diferenciada em suas peculiaridades existentes como a sua localização, o trabalho de subsistência doméstica, os meios de locomoção fluvial implicam em um processo peculiar que envolve a realidade no contexto de uma educação que promova o desenvolvimento da cidadania em que se pode formar um cidadão para a realidade ribeirinha em que está inserido. Neste caso, o trabalho educativo reforça as questões voltadas ao processo de formação educacional, e como tal evidenciam elementos de transformação para discutir e analisar e enfrentar os desafios da educação ribeirinha.

Trata-se, portanto, de uma realidade específica onde esforços devem ser redobrados para se alcançar a compreensão de como a pesquisa e a educação podem interagir de forma harmônica com as comunidades escolares em busca de propostas e ações educacionais que contribuam para melhoria da vida das pessoas que convivem nessas comunidades.

\section{O lugar e não lugar dentro da escola}

O etnólogo e antropólogo Marc Augé (2012) conceitua que o não lugar é aquele onde a identidade perdeu a sua relação com a pessoa, ou seja, uma escola que organiza suas aulas igual as aulas dos lugares urbanos acabam por oferecer uma escola de "não lugar" para os alunos daquela região. Se os conteúdos escolares não estiverem atrelados à vivência das comunidades ribeirinhas, a escola apresenta seus conteúdos sem uma identidade local. Giddens (1991, p. 22) também teorizou sobre o tema considerando que "Em condições de modernidade, o lugar se torna cada vez mais fantasmagórico: isto é, os locais são completamente penetrados e moldados em termos de influências sociais bem distantes deles", ou seja, neste caso, distante do cotidiano ribeirinho.

Aliado a vivência do espaço, é importante atentar-se também para a percepção corporal (Merleau-Ponty, 2011), que, nestes espaços os ribeirinhos assimilam cotidianamente. $\mathrm{O}$ corpo traz as marcas de uma vivência intensa com o 
ambiente: é o remar e equilibrar-se na canoa, os pesados sacos de açaí e castanha, a dureza do caminhar nos trilhos - tudo no intenso sol ou torrente chuva imposto pelo clima amazônico. Tem-se aqui um exemplo para que a escola transforme essas marcas em um discurso de autoestima dessas pessoas como características de um homem forte, saudável, exemplo vivo de sua identidade.

O tempo e as relações históricas também são pontos que os pesquisadores em educação devem considerar, pois é através deles que se organiza o cotidiano. Para Giddens (1991, p. 22), “[o] advento da modernidade arranca crescentemente o espaço do tempo fomentando relações entre outros 'ausentes', localmente distantes de qualquer situação dada ou interação face a face." Essa forma pós-moderna de vivenciar tempo e espaço são completamente diferentes da forma que homens e mulheres vivenciam seu dia a dia nos espaços de rios e florestas. Neste sentido, os educadores e pesquisadores precisam atentar-se em suas práticas, pois, como lembra Candau (2008), a escola vem tratando os conteúdos ditos universais, mas que na verdade são marcas de uma cultura europeia que vai se impondo nas escolas e deixando a desejar a inclusão da identidade das pessoas que realmente frequentam a Escola.

O tempo para o ribeirinho é completamente encaixado e ajustado para sua sobrevivência, pois, há o tempo e a hora de conseguir o pescado, o tempo de plantar, o tempo de colher, a hora certa determinada pela natureza para chuva e enchentes, bem como para o período de estiagem. Há também a hora da navegação e a hora do recolhimento, uma vez que navegações pequenas são inseguras no Rio Madeira (Rezende, 2010). Estas especificidades de ajuste do tempo do ribeirinho ao tempo de se estudar na escola, deve ser também incluída como uma situação a ser organizada de acordo com as necessidades da comunidade escolar.

O diálogo e entrosamento para intervenções educacionais em regiões tradicionais ribeirinhas amazônicas devem ser cuidadosos, pois os ribeirinhos são resilientes em sua cultura (Simão, 2016). Por mais que a escola colonizadora tenha atuado na região, as comunidades mantém seus hábitos e costumes, inclusive adaptam-se sem abrir mão do seu modo de ser e ver o mundo. Estes povos vêm enfrentando os impactos de desenvolvimento econômico provoca- 
dos principalmente pela construção de hidrelétricas e desmatamento sempre na defesa de manter seus espaços e modos de vida, pois estas ações também provocam deslocamentos e enchentes, forçando-os a deixar seus lugares identitários para não lugares, ou seja, os ribeirinhos agem de forma estratégica como sujeito que recebe a informação, faz a síntese, a bricolagem, reinterpreta e sintetiza a partir de sua experiência (Certeau, 2011).

Diante desta resiliência ribeirinha, vê-se que os povos da floresta são parceiros das propostas sustentáveis para envolver sujeitos professores e alunos na linha crítica de ações e práticas educativas ambientais.

Outro ponto extremamente importante, é cuidar e observar se a educação nessas comunidades ribeirinhas está organizada para contribuir e manter as pessoas em suas localidades, ou se a educação está incentivando a juventude a sair de um espaço tão rico e saudável, empurrando-as para os espaços urbanos e, consequentemente, para as periferias perigosas e violentas. E, a escola é um desses lugares das estratégias, onde os sujeitos podem dar golpes no sistema com táticas de construir através de seus saberes seu próprio desenvolvimento sustentável e o bem viver.

Norberto (2020, p. 212) assim verifica a educação em sua pesquisa sobre a região no Baixo Madeira:

O êxodo rural motivado pela falta de investimento na educação traz problemas a toda comunidade. Essa, aliás, é uma estratégia colonizadora. Manter um sistema educativo fragmentário, que não se dirige ao grupo senão por tabela. As novas formas provocam lacunas que favorecem inclusive a penetração de outros fatores das novas colonizações, como a TV, jogos eletrônicos e músicas de má qualidade.

O cuidado para com uma prática educacional que faça conexão entre os conteúdos escolares que abordem as situações de vida de cada lugar e tempo torna-se cada vez mais latente, pois o apego aos conteúdos tradicionais e universais pode ser traidor e ocupar quase todo o tempo de aprendizagem escolar, fazendo com que os conteúdos de necessidade das comunidades ribeirinhas fiquem sempre para depois ou fora das salas de aulas. Diante das relações que 
se efetuam, problemas voltados ao êxodo rural poderiam ser evitados se a escola agregasse a história dos lugares à comunidade escolar, de forma que o planejamento dos conteúdos estivesse voltado para ações educacionais capazes de contribuir com a permanência das pessoas em suas comunidades.

\section{A educação ribeirinha no contexto ambiental sustentável}

O tempo e o espaço devem permear a organização de uma interação educacional e de pesquisa de forma que os alunos agreguem os conhecimentos escolares aos seus conhecimentos culturais, tanto nas áreas de lazer, esportes e artes como nas áreas econômicas e de trabalho. Este universo de proposições pode envolver a EA e, contemplando um todo, evitará o desencaixe da separação entre o tempo e o espaço conforme teorizou Giddens (1991), evitando assim, uma escola com conteúdo desconectado e desinteressante para os alunos onde os mesmos acabam absorvendo informações e conhecimentos que contribuem mais para agravar a devastação ambiental do que para impedir seu avanço.

Aglutinando os saberes da educação formal aos saberem locais e respeitando o tempo de cada lugar, pode-se evitar também que as escolas se tornem instituições desconexas das realidades locais, pois "As instituições desencaixadas dilatam amplamente o escopo do distanciamento tempo-espaço e, para ter este efeito, dependem da coordenação através do tempo e do espaço" (Giddens, 1991, p. 24). Ainda para ao mesmo autor, essa prática serve para distanciar os sujeitos de seu cotidiano e modos de vida - o que acarretará em concordância com a invasão das propostas consumistas e exploração dos recursos naturais de forma destruidora.

Candau (2008) teoriza que nossas escolas precisam ser reinventadas justamente porque a escola pouco se preocupa com esse universo cultural de lugar, tempo e espaço onde os jovens se localizam hoje. Para o adolescente e jovem ribeirinho, isso ainda é mais específico porque ele habita um local que é enxergado preconceituosamente como "atrasado" - pouco se incentiva ou se discute na escola o que se pode oferecer para o jovem como perspectiva de futuro seguro nestas localidades, porque parece que sociedade e a escola só compreendem a vida melhor e desenvolvida em espaços urbanos. 
Candau (2008, p. 17) enfatiza que: “[...] as relações entre educação e cultura (s) nos provocam a situar-nos diante das questões colocadas hoje pelo multiculturalismo no âmbito planetário e de cada uma das realidades nacionais e locais em que vivemos". Sendo assim, a educação é também responsável por incluir os alunos ribeirinhos como membros deste planeta, respeitando suas especificidades.

Se a atividade laboral e cotidiana de quem convive na região ribeirinha e florestal é justamente viver da extração dos recursos naturais, e, o fazem sem destruir o meio ambiente, tem-se nesta realidade o melhor exemplo de educação ambiental. Portanto, para que educadores sejam sujeitos de aprendizagens (Freire, 2002) deverão incluir esses saberes na construção de um projeto de EA colocando os alunos como portadores desse saber ancestral nos cuidados com seu ambiente.

A legislação da educação do campo, em seu Decreto no. 7.352 de 04 de novembro de 2010, diz em seu Art. 2º que são princípios da educação do campo:

I - respeito à diversidade do campo em seus aspectos sociais, culturais, ambientais, políticos, econômicos, de gênero, geracional e de raça e etnia; II -incentivo à formulação de projetos político-pedagógicos específicos para as escolas do campo, estimulando o desenvolvimento das unidades escolares como espaços públicos de investigação e articulação de experiências e estudos direcionados para o desenvolvimento social, economicamente justo e ambientalmente sustentável, em articulação com o mundo do trabalho.

Para que a lei seja cumprida e as necessidades das pessoas desses lugares sejam contempladas, o planejamento de aulas precisa incluir uma revisão cuidadosa dos livros didáticos, excluindo conteúdos que em nada contribuem para a vida dos alunos, e, considerar apenas os conteúdos que dialogam com os espaços, modos de vida e atividades sociais dos moradores, que, neste caso, na região do Baixo Madeira identifica-se como atividade de extração dos produtos da floresta, agricultura de subsistência e avanço das atividades de exploração do ouro, madeira e água - estes últimos ofertam apenas subemprego. 
Em seguida, sugere-se substituir parte dos conteúdos não relevantes para os alunos por outros textos e conteúdo que envolvam mais o cotidiano da comunidade, principalmente organização de projetos que tratem da reflexão dos impactos ambientais sofridos pela comunidade e sua respectiva sustentabilidade. Essas ações podem ser organizadas através de um Projeto de formação de professores em EA numa perspectiva crítica e reflexiva conforme proposto por Tozoni-Reis (2014).

É necessário abrir o leque dessa responsabilidade da aprendizagem escolar e avançar um pouco mais para propostas de conteúdos escolares onde a EA crítica contribua para que o ribeirinho enfrente a pressão de destruição ambiental que ele vivencia cotidianamente por parte do desenvolvimento econômico e insustentável.

A cultura do consumismo e da alienação midiática toma conta a cada dia que passa do tempo e espaço dos jovens ribeirinhos que, sem perceber, vão aderindo à invasão consumista e ilusória que seus espaços e tempo sofrem com a destruição ambiental.

Agudo e Tozzoni-Reis (2014) apontam que investir em formação continuada de professores a partir da pesquisa-ação é uma forma de potencializar as ações de EA no cotidiano escolar, bem como estudar de forma co-participativa, com mais detalhes, as realidades vividas. A EA deverá ir além de simplesmente informar hábitos de consumismo e cuidados com o lixo: deverá propor uma educação que envolva a comunidade escolar num grande debate de desenvolvimento de suas comunidades a partir de sua cultura e proposta de sustentabilidade coerente com uma região de rios e florestas.

Nesse sentido, Tozoni-Reis (2005) acredita que os professores envolvidos na pesquisa podem mediar a construção e organização de uma proposta educacional bastante dialogada com os alunos e demais membros da comunidade escolar e proporcionar um ambiente em que os alunos se sintam estimulados a estudar com afinco, satisfazendo seus anseios pessoais e da comunidade como sendo o seu lugar de estar, estudar, cuidar e construir melhorias economicamente sustentáveis. Para tanto, a EA é um tema importantíssimo que, além de ser uma preocupação mundial, é de extrema relevância para a 
região que necessita de investimentos na divulgação de conhecimentos científicos para fomentar organizações sociais conscientes para defender, nesse caso, a Amazônia e sua biodiversidade.

A escola e as ações planejadas por seus educadores são espaços privilegiados para o desenvolvimento da EA que, além de garantir o acesso de informações à comunidade escolar nas mais diversas formas, proporciona também um debate que fortalece a consciência crítica, pois as questões ambientais impõem desafios, principalmente no que diz respeito à compreensão da relação homem e natureza, bem como os desafios para construção de um ambiente sustentável que hora se apresenta completamente degradado (Guimarães, 2004).

Esses povos da floresta vivem e sofrem as duras consequências da pós-modernidade movidos pelas regras do capitalismo contemporâneo que os coloca apenas na condição de subordinados. Giddens (1991, p. 38-39) assim analisa esse contexto:

Nas civilizações pré-modernas, contudo, a reflexividade está ainda em grande parte limitada à reinterpretação e esclarecimento da tradição, de modo que nas balanças do tempo o lado do "passado" está muito mais abaixo, pelo peso, do que o do 'futuro'. Além disso, na medida em que a capacidade de ler e escrever é monopólio de poucos, a rotinização da vida cotidiana permanece presa à tradição no antigo sentido.

A tomada de consciência de que seus espaços estão sendo invadidos deverá ser uma peça-chave a ser trabalhada pela educação nessas localidades. Assim, a organização de uma pesquisa-ação conjunta poderá não só fortalecer laços de confiança entre pesquisador, professores e demais membros da comunidade escolar, como também propiciar mudanças e proposições de consciência política para criação de associações e fóruns de discussão popular acerca da invasão que a cultura silenciosa do capital se instala no cotidiano ribeirinho.

Destaca-se, como elemento chave dessa invasão, a comunicação via internet, TV, rádio e a linguagem comunicativa recheada de ilusões que certamente colocará o extrativista natural como escravo de mineradoras, fazendeiros e grandes indústrias exploradoras que limitam as relações humanas a uma 
ficha simbólica: o dinheiro como o completo desencaixe entre o homem, o tempo e seu espaço (Giddens, 1991).

O dinheiro nas comunidades ribeirinhas não tem nenhuma relação encaixada com o seu tempo-espaço, uma vez que o preço da castanha, do açaí, do peixe e demais produtos agrícolas que são cultivados sem agrotóxicos tem, na lógica do mercado, preço similar ou até inferior ao dos alimentos cultivados com agrotóxicos ou em formas menos saudáveis. Esta deve ser uma reflexão provocada pela escola em sua proposta de educação ambiental, dentre outras interrogativas: por que os homens da floresta são tratados tão desigualmente para receber e tão igualmente para vender? Como um professor discutirá a agenda ambiental que prevê a sustentabilidade enquanto as comunidades dos cidadãos nos espaços ribeirinhos estão sendo destruídas e se transformando numa comunidade insustentável?

Essa insustentabilidade pode ser exemplificada pela exploração econômica, como por exemplo, através do empreendimento hidrelétrico a partir do qual o "tempo e espaço" do homem ribeirinho foi invadido sem pedir licença, de forma enganosa com um "falso desenvolvimento" e desrespeito às Leis ambientais, conforme descreve Cavalcante (2012, p. 139-140):

No caso evidenciado, a implantação das usinas do Rio Madeira promove a desarticulação da cultura tradicional amazônica com a desapropriação da população ribeirinha sob a influência do reservatório; o rompimento do cultivo na várzea; a desarticulação da pesca; o deslocamento e o surgimento de novos povoados; o desmatamento para conversões de novos usos e ocupação de novas áreas; a redefinição nos limites em unidades de conservação em função do reservatório e a migração de centenas de trabalhadores envolvidos na construção da usina. Tais fatos fomentam a discussão deque os projetos de infraestrutura na Amazônia são implantados desconsiderando a cultura local ou mesmo da política ambiental.

Diante dessa realidade, a Escola, através da EA pode ser fomentadora de um olhar crítico ao desenvolvimento ofertado ao local. Essa deve promover também o acesso aos saberes sistematizados pelas pesquisas científicas na região 
do baixo madeira (Simão, 2010), de forma dialogada com a visão de vivência dos estudantes, para que estes estabeleçam uma relação acerca do que o mundo científico registrou e analisou sobre seus espaços, suas riquezas, modos de vida, cultura e, principalmente, como a destruição está invadindo cada vez mais a região. Os alunos devem ser levados a conhecerem o funcionamento do sistema capitalista ao qual se insere o país e, como seus espaços sofrem a exploração da matéria prima sem nenhuma preocupação com o homem que o habita.

Nas escolas ribeirinhas, professores e os alunos são fundamentais nas práticas educativas ambientais, pois esses possuem um vasto conhecimento dada sua vivência no espaço natural, de modo que neles se desenvolvem ações transformadoras para contribuir em uma prática educativa ambiental promissora.

No entanto, verifica-se ainda uma lacuna na formação desses profissionais, pois muitas dificuldades são encontradas para se trabalhar com a temática de EA uma vez que não receberam em sua formação os conteúdos, ou mesmo uma disciplina, que contemplasse essa necessidade (Barba, Lima, Nobre, 2021).

Ainda para os mesmos autores supracitados, o contexto amazônico ribeirinho deve estar inserido nas ações dos projetos pedagógicos, contemplando o contexto da realidade escolar nas dimensões ambientais, culturais, sociais e deixando bem claro as diferenças entre o campo e a cidade pois, só assim a educação em escolas ribeirinhas pode adquirir esse olhar específico, identitário e diferenciado para atuação da EA. Em geral, observa-se que as os conhecimentos ambientais adquiridos na escola seguem somente o que está previsto no calendário, como dia da árvore, dia Mundial do Meio Ambiente, ou seja, constitui uma prática extremamente limitada diante da complexidade e necessidade que a temática educacional exige.

O caminho da interdisciplinaridade que envolva o contexto sociocultural ainda é uma prática a ser conquistada pela educação ribeirinha de forma que fica evidente cada vez mais a necessidade da construção de "[...] um Projeto Político Pedagógico que seja incorporado nas bases da autonomia da Escola ribeirinha e do campo buscando a emancipação dos estudantes através do trabalho docente" (Barba; Lima; Nobre, 2021, p. 230). 
Outra lacuna que merece atenção são as políticas públicas de educação que atendam especificidades das escolas ribeirinhas, tanto nas esferas municipal como estadual. Estas deixam muito a desejar em ações mais efetivas, principalmente na melhoria do transporte, na alimentação, no saneamento básico, no tratamento da água potável, entre outras. Desta forma, mesmo observando uma tentativa de integrar a EA nos currículos pode-se dizer que esta é uma tarefa que ainda está em aberto e carece de contribuição a partir dos resultados que as pesquisas em educação podem oferecer para mudança dessa realidade.

\section{Considerações finais}

Por fim, espera-se que a reflexão aqui proposta por este trabalho auxilie pesquisadores em educação e educadores da região a construírem dentro dos espaços escolares conteúdos que levem os alunos e demais membros das comunidades escolares a alcançarem uma postura de cidadãos responsáveis por defender a preservação dos recursos naturais, bem como o compromisso de se instrumentalizarem em associações, sindicatos e outros tipos de ONGs capazes de estabelecer o diálogo e/ou embate com o invasor e explorador, para que estes atuem na região com respeito e parceria dos moradores em busca de um desenvolvimento sustentável.

Agindo dentre os parâmetros propostos acima, entende-se que a escola e a pesquisa estarão, de fato, contribuindo para a educação ambiental e desenvolvimento sociocultural e econômico da região de forma consciente, democrática e sustentável. Para tanto, a escola, através de seus professores e gestores, deve partir dos conhecimentos pesquisados na região, organizá-los pedagogicamente em diálogos com a comunidade escolar e assim definir seus conhecimentos para uma educação ambiental que integre espaço, corporeidade, cultura, trabalho, democracia e bem viver.

Nesse contexto, o lugar, o espaço e o tempo devem ser alvos específicos de pesquisadores em educação e devem estar entrelaçados ao que chamamos de cultura ribeirinha como alicerce teórico para formação de professores e construção de conteúdos escolares em EA. Essa formação e conteúdos, devem tam- 
bém estarem voltados para contribuírem na solução de problemas ambientais vivenciados pelas comunidades em contextos amazônicos contemporâneos.

Conclui-se, portanto, que convivências e entrosamento com as realidades ribeirinhas de trabalho, cotidiano cultural e vivências sociais devem ser o primeiro passo para a aplicação de um projeto de pesquisa em Educação Ambiental voltada para a formação de professores que certamente farão a diferença construindo um olhar menos excludente dentro da sala de aula.

\section{Referências}

AGUDO, Marcela de Moraes; TOZZONI-REIS, Marília Freitas de Campos. Educação ambiental nos anos iniciais do ensino fundamental a partir do conto: "A maior flor do mundo" de José Saramago. In: TOZZONI-REIS, Marília Freitas de Campos; MAIA, Jorge S. da Silva (orgs.). Educação ambiental a várias mãos. Araraquara, SP: Junqueira \& Marin, 2014.

ARIÉS, Philippe. História social da criança e da família. 2. ed. Rio de Janeiro: LTC, 2006.

AUGÉ, Marc. Não lugares: introdução a uma antropologia da super modernidade. 9. ed. Campinas: Papirus, 2012.

BARBA, Clarides Henrich de; LIMA, Mathêus Sampaio da Silva; NOBRE, Renata da Silva. Práticas de educação ambiental em escolas ribeirinhas de Porto Velho, RO. Revista Ambiente \& Educação, v. 25, n. 2, p. 207-232, ago. 2020. Disponível em: https://periodicos.furg.br/ambeduc/article/view/11548. Acesso em: 20 de mar. 021.

BRASIL. Decreto no 7.352, de 4 de novembro de 2010. Política de educação do campo e o Programa Nacional de Educação na Reforma Agrária - PRONERA. Presidência da República - Casa civil. Disponível em: http:// www.educadores.diaadia.pr.gov.br/modules/conteudo/conteudo.php?conteudo=564. Acesso em: 13 de jan. 2021. 
CANDAU, Vera Maria. Multiculturalismo e Educação: Desafios para a prática pedagógica. In: Moreira, Antônio Flávio; CANDAU, Vera Maria. Multiculturalismo: diferenças culturais e práticas pedagógicas. Petrópolis: Vozes, 2008.

CAVALCANTE, Maria Madalena et al. Políticas Territoriais e Mobilidade Populacional na Amazônia: contribuições sobre a área de influência das Hidrelétricas no Rio Madeira (Rondônia/Brasil). Revista franco-brasilera de geografia, no 11, 2011. Disponível em: https://journals.openedition.org/confins/6924. Acesso em: 13 de jan. 2021.

CAVALCANTE, Maria Madalena de Aguiar. Hidrelétricas do Rio Madeira-RO: território, tecnificação e meio ambiente. Tese (Doutorado. Programa de Pós-Graduação em Geografia PPGG. Universidade Federal do ParanáUFPR): Curitiba, 2012.

CERTEAU, Michel de. A invenção do cotidiano: artes do fazer. 17. ed. Petrópolis: Vozes, 2011.

FREIRE, Paulo. Pedagogia da Autonomia: saberes necessários a Pratica Educativa. São Paulo: Paz e Terra, 2002.

GIDDENS, Anthony. As consequências da modernidade. São Paulo: Editora UNESP, 1991.

GIL, Antonio Carlos. Como elaborar projeto de pesquisa. 4. ed. São Paulo: Atlas, 2002.

GUIMARÃES, Mauro. A formação de educadores ambientais. 3. ed. Campinas, SP: Papirus, 2004.

MERLEAU-PONTY, Maurice. Fenomenologia da percepção. 4. ed. São Paulo: Martins Fontes, 2011.

SAVIANI, Dermeval. Escola e democracia. 39. ed. Campinas: Autores Associados, 2007. 
SAVIANI, Dermeval. Pedagogia Histórico-Crítica: Primeiras aproximações. 9. ed. Campinas: Autores Associados, 2005.

SIMÃO, Berenice Perpetua. Atuação das IES e desenvolvimento regional: pesquisa com extensão ou extensão com pesquisa? Dissertação (Mestrado em Desenvolvimento Regional) Programa de Pós-Graduação em Desenvolvimento Regional e Meio Ambiente (PGDRA), Universidade Federal de Rondônia, Porto Velho, RO, 2010.

SIMÃO, B.P.; ATHAYDE, Simone. Resiliência socioecológica em comunidades deslocadas por hidrelétricas na Amazônia: o caso de Nova Mutum Paraná, Rondônia. Sustentabilidade em Debate - Brasília, v. 7, n. 2 p.104-117, mai./ago. 2016. Disponível em: https://periodicos.unb.br/index.php/sust/article/view/15861. Acesso em: 22 de mar. 2021.

REZENDE, Maria Idalina Monteiro. A linguagem jurídica e sua expressão no contexto ribeirinho: a Justiça Itinerante no Baixo Madeira. Dissertação (Mestrado) Programa de Mestrado em Ciências da Linguagem. Universidade Federal de Rondônia - Campus de Guajará Mirim. Guajará Mirim- RO, 2010.

TOZONI-REIS, M.F.C. Pesquisa-ação: compartilhando saberes; Pesquisa e Ação Educativa Ambiental. In: FERRARO JÚNIOR, Luiz Antonio (org.). Encontros e caminhos: formação de educadoras(es) ambientais e coletivos educadores. Brasília: Ministério do Meio Ambiente, 2005, p. 269-276. Disponível em: http://www.mma.gov.br/port/sdi/ea/og/pog/arqs/encontros.pdf. Acesso em: 13 de jan. 2021. 


\section{SUSTENTABILIDADE NO ENSINO SUPERIOR: DISCUTIN- DO AS BASES DE SUA IMPLEMENTAÇÃO EM UMA UNI- VERSIDADE DO INTERIOR DA AMAZÔNIA PARAENSE}

Luís Alípio Gomes

Tânia Suely Azevedo Brasileiro

\section{Introdução}

A sustentabilidade tem sido conclamada como via necessária para uma nova configuração social (Freitas; Freitas, 2016), e tem se tornado ponto central quando se discute a questão do desenvolvimento (Jacobi, 2003).

Para Lima (1997), o conceito de sustentabilidade permite múltiplas interpretações devido a sua polissemia. Enquanto Jacobi (1997) afirma que a noção de sustentabilidade envolve uma inter-relação entre justiça social, qualidade de vida, equilíbrio ambiental e a ruptura com o padrão de desenvolvimento excludente e destruidor.

Diferentes estudos apontam que as instituições de ensino superior têm um papel preponderante na incorporação da sustentabilidade e estas deveriam se tornar líderes nesse processo, a partir da implementação de novos paradigmas, em seus cursos e currículos (Caeiro et al., 2013; Gomes; Brasileiro, 2018; Guerra; Figueiredo, 2014; Junyent; Ciurana, 2008; Lozano et al., 2013).

O presente capítulo apresenta resultados da pesquisa de doutorado a respeito da implementação da sustentabilidade em uma universidade no interior da Amazônia paraense. Para elaboração dessa pesquisa, partiu-se dos seguintes questionamentos: como tem ocorrido o processo de implementação da sustentabilidade no âmbito de uma instituição de ensino superior no interior da Amazônia? Que estratégias foram adotadas para viabilizar esse processo e que lições ou aprendizados podem ser extraídos considerando o contexto amazônico?

Este texto está organizado em 5 (cinco) seções, além desta introdução. $\mathrm{Na}$ segunda seção aborda-se as bases conceituais da sustentabilidade no ensino supe- 
rior e busca-se compreender o processo de implementação da sustentabilidade. A terceira seção explica-se os procedimentos metodológicos que foram adotados na pesquisa. Em seguida, na quarta seção encontram-se os resultados analisados e discutidos, finalizando com as considerações finais sobre o objeto abordado.

\section{Sustentabilidade e Educação Superior}

A formação na universidade não pode simplesmente satisfazer às necessidades e exigências do mercado de trabalho, pois, se assim fosse, estaria voltada apenas para o treino (Coelho, 2016). Junyent; Ciurana (2008) destacam que a Educação Superior desempenha um papel crítico na transição para um futuro sustentável na sociedade e as universidades deveriam funcionar como locais de pesquisa e aprendizagem para o debate sobre a sustentabilidade. Ressaltam que "um fator decisivo para alcançar a cultura da sustentabilidade é a educação dos universitários como futuros profissionais [...] caso contrário, o caminho para um futuro sustentável permanecerá pouco claro" (Junyent; Ciurana, 2008, p. 764).

Para Chalkley (2006), a contribuição mais importante do ensino superior para a sustentabilidade consiste em preparar um grande número de graduados, em que os conhecimentos, as habilidades e os valores aprendidos permitam que empresas, governos e à sociedade como um todo façam progressos rumo às formas mais sustentáveis de viver e trabalhar. Neste sentido, um dos principais desafios do ensino superior seria encontrar as maneiras mais eficazes de produzir um grande número de graduandos que tenha alcançado a literacia ou "alfabetização" em sustentabilidade. Essa preocupação com os resultados e compromisso da instituição deve-se em parte para rebater a acusação que muitas universidades estavam tentando apenas fazer um "greenwash"1 da instituição sem realizar ações ou medidas mais consequentes (Disterheft et al., 2013; Wright, 2004).

A educação para a sustentabilidade deve ter uma preocupação pela busca do conhecimento, das habilidades e dos resultados efetivos (Shephard, 2008), revelando a necessidade do aprofundamento das competências e das estratégias pedagógicas.

1 Expressão cujo sentido é causar apenas uma impressão que se adota os princípios de uma instituição comprometida com a sustentabilidade, com os valores “verdes", mas que fica apenas na aparência e na superficialidade. 
Segundo Frisk; Larson (2011), o sistema educacional está na contramão da educação para a sustentabilidade, tendo em vista que a tendência nas escolas, e mesmo nas universidades, é ensinar a competir, uma vez que o foco tem sido o desempenho do indivíduo ao invés de se enfatizar as soluções coletivas para enfrentar os problemas sociais e ambientais. Defendem o esforço de se integrar a pesquisa comportamental, competências da sustentabilidade e a educação pedagógica (education pedagogy) para uma educação transformadora.

Neste sentido, tanto estudos em nível nacional quanto internacional foram desenvolvidos com o intuito de abordar a Educação Superior e a Sustentabilidade (Caeiro et Al., 2013; Carvalho; Cavalari; Silva, 2017; Disterheft et Al., 2012; Gomes; Brasileiro, 2018; Guerra, 2015; Guerra; Figueiredo, 2014; Leal Filho; Manolas; Pace, 2015a, 2015b; Ruscheinsky; Guerra; Figueiredo, 2015).

\section{Implementação da sustentabilidade no ensino superior}

Geli e Leal Filho (2006) fazem referência a numerosas conferências e reuniões internacionais que realçaram a sustentabilidade no Ensino Superior.

A sustentabilidade engloba diferentes dimensões das instituições de ensino Superior (Gómez et al., 2015; Lozano et al., 2015). Para Caeiro (2019) e Kapitulčinová et. al. (2017), as dimensões podem ser representadas conforme mostra a figura 1 :

Figura 1 - Dimensões da sustentabilidade nas universidades

\section{Dimensões da sustentabilidades nas IES}
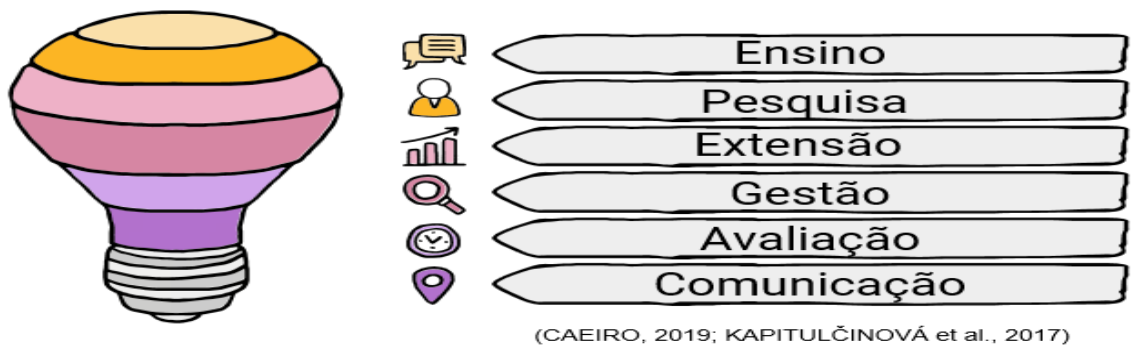

Fonte: Elaborado pelos autores (2021), adaptado de Lozano et al. (2015) e Caiero (2019). 
As dimensões contempladas são: (i) instalações ou operações no Campus; (ii) gestão da organização; (iii) ensino; (iii) pesquisa; (iv) extensão; (v) gestão; e (vi) avaliação e comunicação (Caeiro, 2019; Kapitulčinová et al., 2017). As dimensões representadas pelas engrenagens têm o papel de dar impulso e fazer funcionar a universidade, além de gerar uma ideia de interconexão das partes envolvidas.

Considerando tais dimensões, é necessário analisar como o processo de implementação propriamente dito ocorre nas instituições. Para Aguilar Villanueva (1993b, p. 43), o termo implementação pode ser compreendido como:

Llevar a cabo, llevar a efecto, efectuar, realizar, producir, cumplir, culminar, completar [...] El verbo denotala acción que se ejerce sobre um objeto, considerado falto, defectuoso, desde um certo punto de vista, com el fin de dotarlo de todos los elementos necessários para que lleque a su perfección o acabamento. En este contexto es obvio que lo que se implementa, el objeto de la acción denotada por el verbo implementar, es la política. Procede entonces, logicamente, uma clara distinción entre la política y e lacto de implementarla

Implementar é um verbo que expressa ação no sentido de fazer cumprir ou realizar algo que foi previamente discutido ou planejado. Portanto, pode-se seguir modelos variados de implementação, como o verticalizado (top-down) e o tipo da base para o topo (bottom-up).

Observa-se que, no primeiro caso, a orientação é disparada pelas instâncias superiores em forma de espiral até chegar nas demais instâncias departamentos, salas e indivíduos. As instâncias superiores podem ser representadas pelo Sistema Nacional de Educação, que no caso brasileiro ainda não está constituído. Depois, haveria o Sistema Nacional de Educação Superior, que poderia ser a Secretaria de Educação Superior (Sesu/MEC); em seguida, viriam as instituições de ensino superior (IES) e seus diferentes órgãos e instâncias colegiadas até chegar à sala de aula e aos indivíduos. A linha inversa, bottom-up, se iniciaria a partir dos indivíduos e da sala de aula até alcançar as instâncias superiores. A figura 2 ilustra este processo. 
Figura 2 - Implementação da sustentabilidade no processo top-down approach.

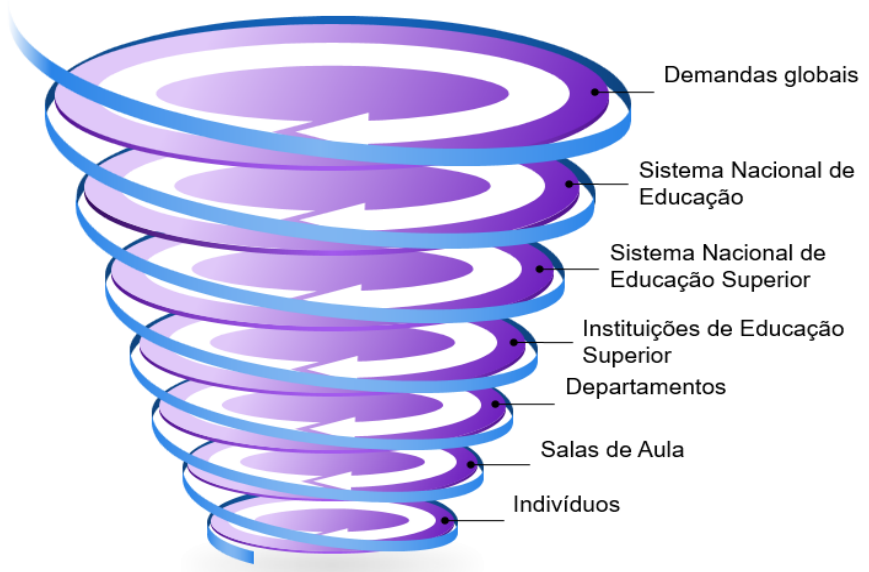

Fonte: Elaborado pelos autores (2021), adaptado de Kapitulčinová et al. (2017).

Não existe uma fórmula ou receita para o processo de implementação. As abordagens ora mencionadas são foram sendo construídos ao longo do tempo. Independentemente da forma e de como ocorre, é importante reconhecer que ocasionalmente podem ser encontrar elementos facilitadores ou barreiras relacionadas a incorporação da sustentabilidade no ensino superior.

\section{Procedimentos metodológicos}

Esta pesquisa doutoral adotou o método misto (Creswell, 2010; Flick, 2009), que consiste em empregar tanto a técnica qualitativa quanto a quantitativa, ou a combinação das duas (Creswell, 2010; Flick, 2009). Ela foi realizada na Universidade Federal do Oeste do Pará (Ufopa), com sede no município de Santarém, Estado do Pará, criada pelo desmembramento do Campus da Universidade Federal do Pará (UFPA) e da Universidade Federal Rural da Amazônia (UFRA), Polo Tapajós.

Adotou-se neste estudo a pesquisa bibliográfica e documental, sendo o corpus documental da pesquisa constituído pelos Projetos Pedagógicos dos Cursos (PPCs) das Licenciaturas da Ufopa, juntamente com os relatórios produzidos pelas visitas da Comissão de Avaliação dos cursos do INEP/MEC. A 
opção pelos cursos de licenciatura deve-se ao fato de os professores exercem um papel fundamental na disseminação e formação sobre a temática da sustentabilidade de futuras gerações desde a educação infantil. Foram analisados os cursos de História, Informática Educacional, Pedagogia, Matemática-Física, Letras Português-Inglês, Geografia e Biologia, ofertados pela Ufopa e seus respectivos relatórios de avaliação de cursos, anunciados anteriormente.

O software NVivo, versão 12 plus, foi utilizado para auxiliar no processo de análise desses documentos.

\section{Resultados e discussão}

Com relação aos PPCs dos cursos mencionados, foram observadas as competências e habilidades em preparar os graduandos com os conhecimentos e as habilidades rumo as formas mais sustentáveis de viver e trabalhar (Chalkley, 2006).

Nesse sentido, buscou-se identificar palavras que tivessem alguma relação no seu contexto com a temática da sustentabilidade, tais como "meio ambiente", “ambiental-ecológico", “qualidade de vida” e "sustentável”, assim como outros termos ligados ao processo de transformação das relações sociedade-natureza, como os termos "problematização" e "qualidade de vida". Identificou-se na descrição das competências e habilidades presentes nos PPCs, os dados ilustrados no quadro 1. 
Quadro 1 - Competências e habilidades relacionadas a AC nos cursos de Licenciatura da Ufopa.

\begin{tabular}{|c|l|}
\hline CURSOS & \multicolumn{1}{c|}{ COMPETÊNCIAS E HABILIDADES } \\
\hline História & $\begin{array}{l}\text { "Problematizar, nas múltiplas dimensões das experiências dos sujeitos } \\
\text { históricos, a constituição de diferentes relações de tempo e espaço" (PPC } \\
\text { de História, 2017, p.24) (grifo dos autores) }\end{array}$ \\
\hline $\begin{array}{c}\text { Informática } \\
\text { Educacional }\end{array}$ & $\begin{array}{l}\text { "Conhecer e respeitar o meio ambiente e entendendo a sociedade como } \\
\text { uma construção humana dotada de tempo, espaço e história" (PPC de } \\
\text { Informática Educacional, 2017, p.31). (grifo dos autores) }\end{array}$ \\
\hline Pedagogia & $\begin{array}{l}\text { "[...] processos de ensinar e de aprender, em diferentes meios ambiental- } \\
\text {-ecológicos (PPC de Pedagogia, 2015, p.28). (grifo do autor). }\end{array}$ \\
\hline $\begin{array}{c}\text { Matemática e } \\
\text { Física }\end{array}$ & $\begin{array}{l}\text { "Perceber a conexão entre a Matemática e a Física e sua produção interna } \\
\text { com as questões mais atuais do mundo contemporâneol" (PPC de Mate- } \\
\text { mática-Física, 2015, p.28). (grifo do autor) }\end{array}$ \\
\hline $\begin{array}{c}\text { Letras Portu- } \\
\text { guês-Inglês }\end{array}$ & $\begin{array}{l}\text { "Compreender a linguagem dentro das especificidades culturais, étnicas, } \\
\text { históricas, econômicas e sociais da região amazônica" (PPC de Letras } \\
\text { Português-Inglês, 2014, p. 9). (grifo dos autores) }\end{array}$ \\
\hline Geografia & $\begin{array}{l}\text { "Articular o ensino, pesquisa e extensão [...] com vistas à melhoria da quali- } \\
\text { dade de vida do planeta"(PPC de Geografia, 2014, p.24). (grifo do autor) }\end{array}$ \\
\hline Biologia & $\begin{array}{l}\text { "Buscar a melhoria da qualidade de vida da população humana, trabalhando } \\
\text { de maneira sustentada visando à preservação do meio ambiente e da diver- } \\
\text { sidade animal e vegetal"(PPC de Biologia, 2014, p.24). (grifo do autor) }\end{array}$ \\
\hline
\end{tabular}

Fonte: Elaborado pelos autores (2021), com base na análise dos PPC dos Cursos de História (2017), Informática Educacional (2017), Pedagogia (2015), Matemática e Física (2015), Letras Português-Inglês (2014), Geografia (2014), Biologia (2014) da Ufopa.

Algumas competências e habilidades contempladas nos PPCs dos cursos apresentam uma preocupação com a formação dos graduandos a partir da noção de sustentabilidade (Jacobi, 1997).

A fim de verificar como os cursos foram avaliados com relação à abordagem da sustentabilidade, solicitou-se os relatórios de Avaliação dos Cursos de Licenciatura junto ao setor responsável pelo acompanhamento do reconhecimento dos cursos, vinculado à Pró-Reitoria de Ensino da Ufopa. Nos Relatórios desses cursos constam análises relacionadas a integração da Educação Ambiental às disciplinas de modo transversal, contínuo e permanente. Nos relatórios foi possível extrair os pareceres dos Avaliadores externos, conforme consta no Quadro 2: 
Quadro 2 - Pareceres dos Cursos estudados em relação a incorporação da sustentabilidade a partir da Educação Ambiental.

\begin{tabular}{|c|c|}
\hline Curso & Parecer \\
\hline Português-Inglês & $\begin{array}{l}\text { As políticas de Educação Ambiental aparecem em } \\
\text { todas as disciplinas da Formação I com } 400 \text { horas } \\
\text { (Português-Inglês/Ufopa, 2014a, p. 15)². }\end{array}$ \\
\hline Biologia & $\begin{array}{l}\text { Há integração da educação ambiental às disciplinas } \\
\text { do curso de modo transversal, contínuo e perma- } \\
\text { nente (Biologia/Ufopa, 2014b, p. } 8)^{3} \text {. }\end{array}$ \\
\hline Matemática-Física & $\begin{array}{l}\text { Foi observado no PPC que as Políticas de educa- } \\
\text { ção ambiental estão contempladas nas atividades } \\
\text { complementares, nos Seminário Integradores e na } \\
\text { disciplina Educação Ambiental (optativa) (Mate- } \\
\text { mática-Fisica/Ufopa, 2015a, p.10) }\end{array}$ \\
\hline Geografia & $\begin{array}{l}\text { Destaca- se a existência do componente curricular } \\
\text { obrigatório denominado de Educação Ambiental } \\
\text { (51 horas). (Geografia/Ufopa, 2016a, p. } 18)^{5} \text {. }\end{array}$ \\
\hline Informática Educacional & $\begin{array}{l}\text { É ofertada no } 3^{o} \text { semestre a disciplina de Educação } \\
\text { Ambiental que trata entre outros aspectos tratamos } \\
\text { sobre os princípios éticos e filosóficos da relação } \\
\text { entre sociedade e natureza, do desenvolvimento } \\
\text { sustentável relacionado à educação e de aspectos } \\
\text { como qualidade de vida, preservação ambiental de } \\
\text { bens culturais e naturais (Informática Educacional/ } \\
\text { Ufopa, 2017b, p. 13) } \text {. }^{6}\end{array}$ \\
\hline Pedagogia & $\begin{array}{l}\text { Sim, há integração da educação ambiental às } \\
\text { disciplinas do curso de modo transversal, contínuo e } \\
\text { permanente, principalmente por meio de estudos in- } \\
\text { tegradores, projetos de pesquisa e projetos interdisci- } \\
\text { plinares (Pedagogia/Ufopa/E-MEC, } 2015, \text { p. } 9)^{7} \text {. }\end{array}$ \\
\hline
\end{tabular}

Fonte: Elaborado pelos autores (2021), com base nos relatórios de avaliação de cursos das Licenciaturas da Ufopa.

${ }^{2}$ UFOPA/E-MEC. Reconhecimento de Curso de Letras Português-Inglês: Relatório de Avaliação, 2014a.

3 UFOPA/E-MEC. Reconhecimento de Curso de Biologia: Relatório de Avaliação, 2014b.

4 UFOPA/E-MEC. Reconhecimento de Curso de Matemática-Física: Relatório de Avaliação, 2015a.

5 UFOPA/E-MEC. Reconhecimento de Curso de Geografia: Relatório de Avaliação, 2016a.

6 UFOPA/E-MEC. Reconhecimento de Curso de Informática Educacional: Relatório de Avaliação, 2017b.

7 UFOPA/E-MEC. Reconhecimento de Curso de Pedagogia: Relatório de Avaliação, 2015b. 
Não obstante esses pontos levantados, que atribuem visibilidade à questão da sustentabilidade nos Relatórios de Avaliação dos Cursos, outras avaliações manifestadas se reportaram de maneira "vaga" ao item. Por exemplo: “A Ufopa cumpre integralmente ao disposto pela Lei no 9.795", ou "Há integração da educação ambiental às disciplinas do curso de modo transversal, contínuo e permanente” (Pedagogia/Ufopa/E-MEC, 2015, p. 9). Desta forma, não são mostradas evidências que dão sustentação a afirmação presente neste parágrafo ilustrado.

Em outros relatórios de avaliações dos cursos de licenciatura da Ufopa, constatou-se que houve ressalvas sobre essa integração, como a não identificação de atividades e projetos transversais que integrem a temática da sustentabilidade. Tais afirmações apesar de dependerem da "subjetividade" do avaliador, proporcionam importantes reflexões sobre a forma pela qual está sendo efetivada a incorporação da sustentabilidade em alguns dos cursos de licenciatura analisados.

\section{Considerações finais}

A humanidade operou transformações no planeta Terra a tal ponto que as atividades econômicas têm causado grandes impactos sociais, econômicos e ambientais. Não se pode perder de vista a necessidade de mudança marcada pelo consumismo numa sociedade capitalista. Como afirma o ecologista senegalês Babia Dioum, "Ao final, nós conservaremos somente o que amamos. Nós somente amamos o que nós compreendemos. Nós somente compreendemos o que nos é ensinado" (Frisk; Larson, 2011, p. 2).

As competências e habilidades dos graduandos que estão presentes nos PPCs dos cursos de licenciatura expressam a preocupação da formação dos licenciandos com relação a sustentabilidade. Porém, é preciso intensificar mais ações a fim de que não fique apenas no campo da formalidade. Entende-se que "nenhuma instituição na sociedade moderna estão melhores posicionadas e nenhuma é mais obrigada a facilitar a transição para um futuro sustentável do 
que as faculdades e universidades" (Orr, 2002, p. 96). Neste sentido, é importante desenvolver uma política de sustentabilidade socioambiental com ações integradas no ensino, na pesquisa, na extensão e na gestão.

Outra questão que não se pode perder de vista diz respeito a necessidade de intensificar e/ou produzir ações que promovam a sustentabilidade no currículo da universidade para todos os cursos, e não apenas para as licenciaturas. Compreende-se a importância da realização da formação continuada de docentes e servidores técnicos sobre a temática da sustentabilidade, torna-se fundamental para que sua implementação não seja reconhecida como algo imposto, bem como a urgência em promover eventos para debater e dialogar sobre a temática no contexto amazônico.

\section{Referências}

BIOLOGIA/UFOPA/E-MEC. Reconhecimento de curso de Biologia: relatório de Avaliação, 2014.

CAEIRO, S. et al. (EDS.). Sustainability assessment tools in higher education institutions: mapping trends and good practices around the world. Cham: Springer, 2013.

CHALKLEY, B. Education for Sustainable Development: Continuation. Journal of Geography in Higher Education, v. 30, n. 2, p. 235-236, jul. 2006.

CRESWELL, J. W. Projeto de pesquisa: métodos qualitativo, quantitativo e misto. Tradução: Magda Lopes. Porto Alegre, RS: Artmed, 2010.

FLICK, U. Uma introdução à pesquisa qualitativa. 3. ed. ed. Porto Alegre: Bookman, 2009.

FREITAS, M.; FREITAS, M. C. DA S. A sustentabilidade como paradigma: cultura, ciência e cidadania. Petrópolis, RJ: Vozes, 2016. 
GELI, A. M. G. DE; LEAL FILHO, W. Education for sustainability in university studies: Experiences from a project involving European and Latin American universities. International Journal of Sustainability in Higher Education, v. 7, n. 1, p. 81-93, 2006.

GEOGRAFIA/UFOPA/E-MEC. Reconhecimento de curso de Geografia: relatório de Avaliação, 2016.

GOMES, L. A.; BRASILEIRO, T. S. A. Sustentabilidade e Educação Superior na Amazônia. Revista Ibero-americana de Ciências Ambientais. Revista Ibero-americana de Ciências Ambientais, v. 9, n. 6, p. 369-382, 2018.

GÓMEZ, F. U. et al. Adaptable model for assessing sustainability in higher education. Journal of Cleaner Production, v. 107, p. 475-485, nov. 2015.

GUERRA, A. F. S.. Ambientalização e sustentabilidade nas universidades: subsídios, reflexões e aprendizagens. Itajaí - SC: Ed. da UNIVALI, 2015.

GUERRA, A. F. S.; FIGUEIREDO, M. L. Ambientalização curricular na Educação Superior: desafios e perspectivas. Educar em Revista, n. Especial, p. 109-126, 2014.

INEP/MEC. Instrumentos de avaliação de cursos de graduação: presencial e a distância, out. 2017.

INFORMÁTICA EDUCACIONAL/UFOPA/E-MEC. Reconhecimento de Curso de Informática Educacional: Relatório de Avaliação, 2017.

JACOBI, P. Meio ambiente urbano e sustentabilidade: alguns elementos para a reflexão. In: CAVALCANTI, C. (org.) Meio ambiente, desenvolvimento sustentável e políticas públicas. São Paulo: Cortez, 1997.

JACOBI, P. Educação ambiental, cidadania e sustentabilidade. Cadernos de pesquisa, n. 118, p. 189-205, 2003. 
JUNYENT, M.; CIURANA, A. M. G. Education for sustainability in university studies: a model for reorienting the curriculum. British Educational Research Journal, v. 34, n. 6, p. 763-782, 2008.

KAPITULČINOVÁ, D. et al. Towards integrated sustainability in higher education - Mapping the use of the Accelerator toolset in all dimensions of university practice. Journal of Cleaner Production, 2017.

LEAL FILHO, W.; MANOLAS, E.; PACE, P.The Future We Want: Key Issues on Sustainable Development in Higher Education after Rio and the UN Decade of Education for Sustainable Development. International Journal of Sustainability in Higher Education, v. 16, n. 1, p. 112-129, 2015a.

LEAL FILHO, W.; MANOLAS, E.; PACE, P. The future we want. International Journal of Sustainability in Higher Education, v. 16, n. 1, p. 112-129, jan. 2015b.

LETRAS PORTUGUÊS E INGLÊS/UFOPA/E-MEC. Reconhecimento de curso de Letras Português e Inglês: relatório de Avaliação, 2014.

LIMA, G. F. DA C. O debate da sustentabilidade na sociedade insustentável. Revista Política \& Trabalho, n. n.13, set. 1997.

LOZANO, R. et al. Declarations for sustainability in higher education: becoming better leaders, through addressing the university system.(Report). Journal of Cleaner Production, v. 48, jun. 2013.

LOZANO, R. et al. A review of commitment and implementation of sustainable development in higher education: results from a worldwide survey. Journal of Cleaner Production, v. 108, n. A, p. 1-18, 1 dez. 2015.

MATEMÁTICA E FÍSICA/UFOPA/E-MEC. Reconhecimento de curso de Matemática e Física: relatório de Avaliação, 2015. 
PEDAGOGIA/UFOPA/E-MEC. Reconhecimento de curso de Pedagogia: relatório de Avaliação, 2015.

RUSCHEINSKY, A.; GUERRA, A. F. S.; FIGUEIREDO, M. L. Um panorama da sustentabilidade nas instituições de Educação Superior no Brasil. In: Ambientalização e sustentabilidades nas universidades: subsídios, reflexões e aprendizagens. Itajaí - SC: Ed. da UNIVALI, 2015. 


\section{LARGA CAMPANHA DE EDUCAÇÃO PARA AS GEN- TES DO CAMPO: FORMAÇÃO DE PROFESSORAS RU- RAIS BRASILEIRAS (1951-1963)}

Nilce Vieira Campos Ferreira

\section{Introdução}

Inicio este texto lembrando que no caminho da pesquisa, por vezes, nós nos deparamos com fatos intrigantes, que nos levam ao gosto e à prática da escrita e que nos permitem afirmar que se tornam “[...] preciosas ajudas. A história não pode deixar de lado um trabalho que é de natureza literária com as especificidades de um gênero particular. Eis porque escrever história será sempre uma arte e uma tarefa laboriosa, além talvez, de um prazer" (Prost, 2008, p. 252).

De fato, no labor da escrita, emerge este texto histórico no qual aponto indícios de cientificidade e exposição de algumas fontes que registram um tempo no qual, no Brasil, vivenciamos várias campanhas voltadas para a educação no meio rural, entre elas, a Campanha Nacional de Educação rural que foi empreendida a partir de 1951, quando Getúlio Vargas, Presidente da República no Brasil, instituiu a CNER ${ }^{1}$ como um programa educativo de base, coordenado pelos Ministérios de Educação e da Agricultura que articularam planos, recursos financeiros e humanos (Brasil, 1951) para criar e desenvolver ações educacionais no meio rural, com a intenção de ensinar aos campesinos “[...] as coisas para que ele imediatamente aceite e passe a praticá-las [...]”(Ramos, 1954, p. 87).

É preciso destacar que no Brasil dos anos de 1950, o homem rural era visto como um matuto e quase sempre era representado de forma caricaturada. Raramente programas e planos educacionais brasileiros o apresentavam no seu exato relevo humano. A cultura dos rurícolas era desconsiderada e eram enfa-

1 Esta pesquisa foi desenvolvida no âmbito do projeto Formação de Professoras Missioneiras nas Regiões Centro-Oeste e Norte: Mato Grosso e Rondônia/Brasil (1936-1963). Contou com financiamento do Conselho Nacional de Desenvolvimento Científico e Tecnológico CNPq - Processo n. 24497/2018-2. 
tizados determinados estereótipos, como o linguajar considerado inadequado, a pronúncia errada de palavras ou o uso de diminutivos, enfim, os modos rústicos tais como o costume de mascar fumo, as casas de taipa e/ou pau a pique, entre outros modos de ser e de se comportar.

[...] o rurícola, que vive na roça, tem as mãos calejadas do cabo da enxada, pita o seu cigarro de palha, toma a pinga quando há tempo e dinheiro, toca viola, canta abecês, enche a casa de filhos doentes e opilados como ele, como ele sujos e maltrapilhos, vivendo em chocas, dormindo em esteiras ou catres, comendo o que pode, sentindo que é miserável a sua vida, mas convencido que não há possibilidade de transformá-la (Souza, 1954, p. 43).

Desconsiderando as difíceis condições de vida, a ausência de políticas públicas e ou incentivo à população rural e suas famílias, o governo federal empreendeu a CNER propagando que era preciso que a educação de base intervisse com a função de mudar hábitos e permitir que mulheres e homens sentissem “[...] os problemas que os afligiam e pudesse, orientado pelos órgãos competentes resolvê-los” (Gago Lourenco Filho, 1959, p. 17).

A CNER, portanto, pregava o progresso para o campo por meio da educação, ao mesmo tempo que articulava o objetivo de inculcar valores e ideais que deveriam ser incorporados e seguidos pelas comunidades rurais condizentes com o que era esperado no mundo do capital que avançava no Brasil e estimulava a produção e consumo desenfreado, o que exigia mudança de condutas e crenças dos campesinos, caracterizadas como atrasadas.

Faz-se necessário observar que a CNER contribuiu para disseminar à população rural o discurso no qual a sua cultura e costumes eram sinônimos do atraso e da inércia, pois no âmbito da campanha era pregado que o homem rural era um espectador da vida do país, uma figura estranha e de difícil definição, descrito como instável, um homem que vivia à margem dos acontecimentos. Com esses conceitos da população rural brasileira a CNER foi divulgada como uma ampla campanha voltada também para um diagnóstico da vida das populações campesinas. 
Larga campanha de educação para as gentes do campo devem constitutir os instrumentos mais adequados ao levantamento do nível de vida material e cultural das populações brasileiras [...] Não sendo possível conseguir novos processos de trabalho e melhores condições de vida sem um programa educativo de base, abrangendo o lavrador com sua família e as próprias intituições sociais de sua comunidade, devem, nesse sentido os Ministérios de Educação e da Agricultura articular seus esforços, planos e recursos financeiros e humanos (Vargas, 1951, p. 102-103).

Com isso, o ensino para o meio rural brasileiro foi pensado como uma educação de base que implicava "[...] um trabalho educativo que tem por fim integrar o homem do campo no meio em que ele se encontra” (Ramos, 1954, p. 110).

O governo brasileiro, por meio da CNER, pretendia impor medidas para que as famílias permanecessem no meio rural, com a finalidade intrínseca de "[...] despertar o interesse do rurícola pelas suas lides, trazendo-lhe a consciência do valor de seu trabalho; orientá-lo para práticas agrícolas racionais, prepará-lo para o cooperativismo e para o crédito agrícola tão necessário [...]” (Gago Lourenco Filho, 1959, p. 18).

De fato, as ações educativas deveriam despertar o gosto pelos trabalhos no campo, estimular o espírito social, acentuando dever moral e cívico entre docentes e estudantes, de modo que esses princípios alcançassem a comunidade na qual a instituição escolar estava inserida. A escola rural seria uma instituição de divulgação da estrutura cultural e econômica, à qual o governo demandava para influenciar as comunidades rurais brasileiras, de acordo com os interesses do mercado capitalista.

Destaco ainda que a educação dos rurícolas deveria contemplar o mínimo de conhecimentos e estimular a produção e o "progresso econômico" do meio rural.

O mínimo de educação geral necessária a ajudar as crianças, os adolescentes e os adultos a compreenderem os problemas peculiares ao meio em que vivem, a formarem uma ideia exta de seus deveres e direitos individuais e cívicos e a participarem, eficazmente, do progresso econômico e social da comunidade a que pertencem (Conceição, 1954, p. 13). 
Essa forma de ensinar no meio rural foi deliberada pelo Governo Federal também no que se referia à formação de professoras e professores rurais, nas quais foi pensado o "[...] modelo das missões rurais que Lourenco Filho trouxera do México inspirava atividades educativas no ensino rural e propunha reformas no âmbito das políticas educacionais, estabelecendo medidas de desenvolvimento da educação rural [...]" (Ferreira; Lima, 2020, p. 953).

Para isso, responsáveis pelas missões rurais fariam "[...] reconhecimento para proceder à escolha dos sítios mais adequados para o trabalho” (Ramos, 1954, p. 111). Escolhidos esses locais, seria possível “[...] estudar as condições de acesso ao mercado, à densidade e o nível de vida da população rural [...]”, como dito por Ramos (1954, p. 111).

Outra tarefa das missões era identificar instituições, líderes e agentes comunitários que poderiam promover e fomentar a produção agrícola, a distribuição de crédito, serviços de assistência e de educação de jovens e adultos analfabetos. As missões englobariam ainda "[...] o emprego de processos técnicos modernos de difusão, como os do cinema; e, enfim, melhoria das instalações escolares, construção de casas de residência para os professores, organização regional de sua formação [...]” (Bergström Lourenço Filho, 2001, p. 79).

As atividades educativas promovidas pelas professoras "missioneiras" e as escolas no meio rural caberia um papel específico: tornar-se um foco de disseminação de conhecimentos para a formação de pessoas que compartilhassem essas orientações. Professoras treinadas nos cursos de extensão ou cursos normais rurais que eram oferecidos nos Centros de Treinamento da CNER deveriam estimular o "amor" pela vida no campo, auxiliando homens e mulheres na "melhoria" de seu padrão de vida, o que as/os levaria a se interessar pela fixação no meio rural.

Para que isso fosse realizado, era necessária uma formação específica para as professoras rurais para que elas se responsabilizassem e promovessem atividades nas escolas e comunidades nas quais atuavam, tais como círculo de estudos, palestras, conferências, clubes de mães, clubes agrícolas, aulas de campo, enfim promoção de atividades que colaborassem para promover uma ampla transformação cultural do homem e da mulher rural como era 
intento da CNER, mas sempre com o intuito de multiplicar as técnicas e a “[...] eficiência no trabalho, além de promover a elevação do nível de vida da população não urbana [...] que garante, de certa forma, a permanência do homem rural no meio rural, dando-lhe as técnicas necessárias às exigências da vida moderna” (Salgado, 1956, p. 15).

Currículos, programação dos cursos, missões e outras atividades, contudo, visavam formar professoras que incorporassem uma imagem positiva da vida e do homem rural e "[...] dessa forma, a CNER atuou de modo a obter a 'nova "mentalidade' que objetivava implantar, articulando educação, cultura e ação social no meio rural" (Ferreira; Souza; Prado, 2019, p. 46).

Para isso, atividades educacionais, culturais e a formação ofertada a professoras deveria contemplar uma diminuição do tempo de curso que traria, como consequência, "[...] maior leveza ao currículo dos cursos normais rurais. Todavia é de reconhecer como imprescindível, a necessidade de um preparo mínimo essencial, de um domínio seguro das técnicas de ensino [...]" (Teles, 1954, p. 63), com a finalidade "despertar" deveres individuais e cívicos de cada indivíduo, levando brasileiras e brasileiros à aceitação dos programas e projetos propostos.

\section{Já não se trata mais de alfabetizar em massa: mas de substituir uma cultura por outra mais adequada}

Em dezembro de 1951, um relatório apresentado pelo professor Nelson Romero, Diretor Geral do Departamento Nacional de Educação, ao Ministro da Educação brasileira, Ernesto Simões da Silva Freitas Filho, descreveu que “[...] já não se trata mais de alfabetizar em massa, construir escolas, espalhar postos de saúde e sim de substituir uma cultura por outra mais adequada às condições atuais do mundo" (Romero, 1954, p. 185).

Para modificar costumes e culturas campesinas, Romero recomendou ao Ministro da Educação algumas ações, entre elas, a criação de um órgão público ou departamento para coordenar e estimular missões rurais e a criação de centros sociais rurais nas áreas escolhidas em alguns estados brasileiros; formação de técnicos para atuarem na Educação de Base; constituir documen- 
tação e realizar pesquisas sobre o meio rural; levantar o nível das instituições e dos técnicos em atuação; bem como, apoiar técnica e financeiramente projetos existentes (Romero, 1954, p. 185).

Desse modo, a CNER, que fora oficializada em 9 de maio de 1951, pelo Ministro Ernesto Simões, como Campanha de Educação Rural assim se mantinha, já que suas modalidades de serviços se destinavam especialmente às zonas rurais, incluindo as Missões Rurais, Treinamento de Professoras Rurais, de Líderes Rurais, entre outras ações. Nesse contexto, a expressão educação rural era "[...] mais compreensível para o homem do interior do que educação de base" (RCNER, 1959, p. 21).

Com o intuito de uma política educativa que abrisse fundações novas para uma mudança de mentalidade no meio rural brasileiro, a CNER voltou seu olhar para uma educação que levasse a população campesina a compreender "[...] os problemas peculiares ao meio em que vivem, a formarem uma ideia exata dos seus direitos e deveres individuais e cívicos e a participarem eficazmente do progresso econômico e social da comunidade a que pertencem" (Romero, 1954, p. 184).

Com isso, a educação fundamental deveria proporcionar apenas o mínimo de conhecimento teórico e técnico indispensável a um nível de vida compatível com a dignidade humana e com ideais democráticos essenciais ao desenvolvimento dos serviços sanitários, agrícolas e pecuários brasileiros por meio de ações educacionais de base, como descrito em seu regulamento.

II Da Educação de Base

3 - Essa educação é educação de base porque se destina a proporcionar aos indivíduos e às comunidades o número de conhecimentos teóricos e técnicos indispensáveis a um nível de vida compatível com a dignidade humana e com os ideais democráticos e, porque, sem ela, as atividades dos serviços especializados (médicos, sanitários, agrícolas) não seriam plenamente eficazes (RCNER, 1959, p. 26).

Cabia a CNER, portanto, ministrar apenas conhecimentos rudimentares de leitura, cálculo e escrita aos rurícolas, no próprio ambiente doméstico 
muitas vezes, ou nas pequenas escolas nas localidades mais populosas, que lhes serviam para a lida diária com o trabalho agrícola, para estimular o consumo e conduzir ao "progresso" econômico das localidades.

Dessa forma, a CNER legitimava modalidades de intervenção educacional junto ao meio rural "atrasado", de modo a evitar a fuga dos rurícolas para o mundo do trabalho urbano, o que de alguma forma contribuía para formar trabalhadores locais para os latifúndios, além de impedir o fluxo migratório das localidades rurais para as cidades, isto é, ao mesmo tempo no qual a CNER desenvolvia seus próprios projetos, cooperava com "[...] outras entidades na formação de auxiliares para meio rural" (Romero, 1954, p. 186), cujos interesses eram diversos.

No discurso de inauguração do $1^{\circ}$ Centro Regional de Educação de Base em Colatina, Espírito Santo/Brasil, Joaquim Moreira de Sousa, Assistente Técnico do Coordenador da CNER, descreveu que profissionais que atuariam na campanha deveriam ser conveniente treinados de modo a promover a aculturação das comunidades, munindo-se de todos os meios necessários para isso, o que implicava difundir a assimilação de elementos culturais que interessavam aos mentores da CNER em detrimento da cultura própria das comunidades rurais.

Dentro do conceito de Educação de Base firmado, agora, mundialmente, aquele que for atingido por sua ação realizadora e reformadora, aprenderá elementos de escrita e leitura, elementos de cálculo, de geografia e de história e de rudimentos de higiene pessoal, coletiva e social. Como o programa pode variar de região para região, de povo para povo, segue-se que há maior flexibilidade possível, no ensino que se quer ministrar. Uma das técnicas usadas, na transmissão de conhecimento, não só úteis, mas indispensáveis às massas, é o trabalho em equipes que se deslocam, depois de constituídas por profissionais treinados, à procura das comunidades, onde mais necessária se torna a sua presença. Médicos, engenheiros, agrônomos, técnicos agrícolas, enfermeiras, assistentes sociais e professoras, depois de convenientemente treinados, em centros de estudos, põem-se em contato com as populações mais atrasadas, e uma vez granjeada sua simpatia e amizade, incute-lhes, por todos os meios e modos, os conhecimentos e noções que sirvam de fundamento à melhoria de suas condições de vida (RCNER, 1959, p. 107). 
Como podemos ver no excerto acima, na campanha empreendida pela CNER, prevalecia o interesse de treinar de forma apropriada, consoante as determinações do governo brasileiro, profissionais que iriam atuar no meio rural e ainda preconizava que deveriam ser empregados quaisquer meios para obterem os resultados esperados. Da mesma forma, a CNER deveria conjugar esforços para cooperar com outras entidades no meio rural, de modo a realizar um levantamento simultâneo dos padrões sanitários, econômicos e educacionais dos rurícolas em uma área delimitada, com o objetivo sistemático de "civilizá-los", de investigar e conhecer as condições econômicas, sociais e culturais do homem do campo, conforme delimitado no regulamento já mencionado neste texto.

Por trás do ideal de atividades de instrução, escondia-se, portanto, outros objetivos explícitos: aumento da produção agrícola, difusão e ampliação do consumo de equipamentos e insumos agrícolas, além de divulgar e facilitar a aceitação das comunidades à tomada de crédito agrícola e aquisição de equipamentos e aparelhos domésticos.

Com uma marcada indefinição política educacional comum aos diversos governos brasileiros e às reformas promovidas ao longo dos anos, da mesma forma era ofertada "[...] a educação rural em inúmeras localidades, vilas e pequenas povoações distantes das cidades permanecia desigual em relação às escolas urbanas, fosse em relação à escola primária, fosse em relação às escolas voltadas para a formação de professores” (Ferreira; Lima, 2020, p. 958).

Consciente dessa realidade, a CNER propôs a criação de Centros Regionais de Educação de Base, Centro de Treinamento de Formação de Professoras/Professores Rurais; estágios para Diretoras/Diretores de Centros de Treinamento de Professoras/Professores Rurais; Cursos de Habilitação de Professoras/Professores Rurais; Cursos de Formação de Educadoras/Educadores de Base. Sob o bordão de elevar o padrão de vida cultural e social do professorado e das comunidades rurais do interior do Brasil, nos Centros de Treinamento e nas Missões Rurais diversas atividades eram comuns, tais como: realização de palestras e a distribuição de folhetos que divulgavam o crédito rural, a ampliação da produção, equipamentos, insumos agrícolas e outros aparelhos para os lares rurais. 
Nessa linha de raciocínio, para Barreiro (1989) a educação dos rurícolas era compreendida "[...] como um fim em si mesma, servindo para acobertar os determinantes estruturais da condição a que se encontravam submetidos os camponeses" (Barreiro, 1989, p. 111).

Desse modo, ocultando a ausência de políticas públicas, tanto de saúde, de educação ou mesmo de outras que poderiam estimular a produção de forma sustentável, ou seja, não era discutida ou apresentada “[...] a existência daquelas condições de precariedade e pobreza entre os camponeses, como a exploração capitalista da força de trabalho agrícola e a expropriação da terra [...]” (Barreiro, 1989, p. 111).

As professoras e outros técnicos, ao atuarem no meio rural, deveriam difundir noções como desenvolvimento e melhoria das condições de vida para as pessoas que viviam no meio rural em consonância ao capitalismo que avançava no Brasil, bem como ações que possibilitassem o controle e a "organização" das comunidades campesinas brasileiras, como comprovamos no excerto a seguir.

Em função desse novo construto, a visão sobre as atividades até então definidas como de ensino agrícola priorizaria não mais a atividade escolar, porém aquela realizada por instituições de assistência técnica e creditícia, visando à qualificação da mão de obra rural adulta e também ao seu controle e 'organização' em 'comunidades rurais', aptas a consumirem a tecnologia estadunidense, definida como a mais adequada. Essas alterações se materializaram tanto na multiplicação do tipo de agências e iniciativas conjuntas brasileiro-estadunidenses, quanto na vitória da vertente que defendia a educação para o campo com base nas práticas, infinitamente menos dispendiosas, do Extensionismo Rural (Mendonça, 2010, p. 141).

A CNER utilizou-se assim da formação escolar oferecida como um instrumento para arquitetar e difundir uma visão das localidades rurais vistas como inferiores e carentes e que precisavam ser "beneficiadas", para incentivar o consumo e as importações brasileiras de máquinas e insumos agrícolas oriundos principalmente do mercado norte-americano. 


\section{Educação rural para "erguer os padrões da comunidade ...”}

A CNER teve origem a partir de o Seminário Interamericano de Educação², promovido pela UNESCO e pela OEA, em 1949, no Rio de Janeiro, que se configurou como momento de reflexão, planejamento e sistematização de diretrizes que projetaram ações iniciais e campanhas de educação rural que avançariam pelos anos 1950. Nessas campanhas, prevalecia a concepção de que o homem do campo deveria ser integrado ao meio social por meio de ações solidárias e cooperativistas e pela divisão do trabalho (Leite, 1999).

Naqueles anos, no Brasil, prevalecia uma relutância de professoras normalistas em atuarem nas escolas localizadas no meio rural. Isso devia-se ao fato de que as muitas escolas rurais existentes não gozavam de prestígio, muito embora, na época, o meio rural brasileiro abrigasse a maior parte da população brasileira. Uma das maneiras encontradas pela CNER para evitar que as professoras que atuavam no meio rural migrassem para as cidades, foi a de ofertar cursos nas localidades ou o mais próximo possível delas.

Considerando que não era aconselhável trazer professoras do interior para estudar nas cidades, a CNER fundou Centros de Treinamento em diversas regiões brasileiras, nos quais as professoras poderiam realizar cursos intensivos de treinamento com duração de 03 a 04 meses para voltarem e exercerem suas atividades nas próprias localidades. Foram criados também cursos normais rurais ou regionais ofertados com duração entre 18 a 24 meses.

Parece-nos inteiramente desaconselhável a prática de trazer essas professoras do interior para treinamento na capital do país por maiores que sejam as facilidades de equipamentos oferecidas por esta. Num país como o nosso, a braços com o drama do êxodo rural, trazer professoras do interior para as grandes cidades é favorecer a migração para os centros urbanos (Romero, 1954,p. 186).

A CNER recomendava que a educação deveria ser reforçada e consolidada pelos órgãos de educação formal, ressaltando que era desoladora a situação

2 Seminário Interamericano de Alfabetização e Educação de Adultos. Relatório. Rio de Janeiro, 1949. mimeo. Arquivo Lourenço Filho-CPDOC. 
na qual se encontrava o meio rural brasileiro no tocante à instrução. Contudo, o mais alarmante era o fato de que "[...] a escassez de investimentos direcionados para a manutenção das escolas rurais, eram os problemas referentes aos professores e à sua falta de instrução" (Lima, 2004, p. 29). Quando, na verdade, o que não havia era uma política pública consolidada de educação rural, prevalecendo o desinteresse político dos governantes, fosse municipal, estadual ou federal.

Desse modo, prevaleciam, nas escolas rurais brasileiras, professores que atuavam nas salas de aula sem habilitação para o magistério, cuja formação e o aperfeiçoamento em larga escala constituíram um dos nortes da campanha empreendida pela CNER. O intuito de oferecer cursos intensivos com duração de três a quatro meses tinha a finalidade imperiosa de "erguer os padrões da comunidade" na qual os campesinos residiam e ensinar "[...] noções de pedagogia, higiene, educação sanitária, horticultura, avicultura, economia doméstica, indústria doméstica, artesanato e recreação, a fim de que possam levantar o nível de ensino em suas escolas [...]" (Romero, 1954, p. 186).

Para alcançar o objetivo de formação do maior número de pessoas possível, os Centros de Treinamento ministravam um tipo de educação diferenciada. Além do treinamento de professoras, ministravam cursos de extensão rural destinados aos agricultores e suas famílias, donas de casa, jovens e outros que se interessassem pelo melhoramento da agricultura e do lar, com vistas "a elevar a condição de vida da população rural", mas no fundo, visando contribuir para evitar ou diminuir o êxodo rural e incitar o consumo de bens, serviços e insumos agrícolas, além de estimular a tomada de crédito junto aos bancos e outros instituições nacionais e internacionais, consoante os objetivos dos gestores da CNER.

As professoras e técnicos, no âmbito no CNER deveriam "ajudar' as pessoas a: a) analisar seus recursos; b) identificar seus problemas; c) reconhecer suas necessidades reais; d) determinar o desenvolvimento das atividades agrícolas, não só a curto como em longo prazo; e) desenvolver sua capacidade de ação (Cleophas, 1955).

Enfim, os Centros de Treinamento constituíam um projeto de formação a ser destinado à população rural com intenção de "recuperá-la" por meio de um programa educativo intensivo da CNER com o objetivo de "melhoria" 
tanto da produção quanto das condições de vida das comunidades, levando-as a se aquietarem no campo e a aceitarem o que lhes era proposto pelas iniciativas governamentais (Ferreira, 2014).

No fundo, o que se pretendia, segundo André Terrise era uma “[...] ação profunda exercida sobre o próprio homem, ação imponderável que imprime à vida um novo sentido". Com isso, "a mudança" teria "poder de choque", um poder do qual o "[...] bom educador procurará tirar o melhor proveito possível deste efeito da surpresa. Aproveitará esse traumatismo para influenciar a personalidade" (Terrise, 1956, p. 164).

Os Cursos Normais Rurais, nível de $2^{\circ}$ grau, pouco se diferenciavam dos cursos de extensão, ministrados com duração de 03 ou 04 meses. A formação ofertada a professoras normalistas rurais era realizada em cursos com duração de 18 meses, nível secundário, para a atuação no magistério rural, a par e ao lado da formação geral e do princípio pedagógico do "aprender-fazendo", cuja forma de ensinar foi incorporada pela CNER a partir das experiências realizadas no primeiro Centro Regional de Educação de Base da CNER em Colatina, Espírito Santo (RCNER, 1959, p. 196).

[...] com a principal função de treinar, preparar os docentes das escolas rurais, os docentes dos próprios cursos e Centros de Treinamento que a CNER for expandindo para a civilização do Brasil, os orientadores, os supervisores de todos os trabalhos de educação. Todas as suas experiências de equipe tendem a forjar outras equipes de têmpera rija e decidida pela causa difícil que lhes é inculcada. (RCNER, 1959, p. 196).

Como podemos comprovar, a partir da análise da transcrição acima, currículos, planejamentos, cursos e métodos eram planejados e aplicados para treinar e orientar docentes no emprego de métodos e técnicas de ensino que, uma vez aprendidos, pudessem ser aplicados nas comunidades de modo a civilizar o meio rural, como convinha à campanha empreendida pela CNER.

Desse modo, a campanha promovia "[...] cursos para professoras municipais ou para qualquer tipo de líder, a fim de levantar-lhes o nível profissional 
e fazer com que se tornem outros tantos instrumentos de penetração das ideias e das técnicas da CNER" (Arreguy, 1959, p. 29).

Nos cursos de menor duração, eram ministrados conhecimentos de ordem teórica relacionados ao aprendizado das matérias do currículo do curso primário e incluíam também conhecimentos de Higiene Rural, Puericultura e Enfermagem, Arte Culinária e Economia Doméstica, Técnicas de Recreação, Organização e Administração Escolar, Noções de Agricultura, Indústrias Rurais, entre outros (RCNER, 1959, p. 196).

Ressalto ainda o caráter que a CNER incorporou na mudança dos hábitos higiênicos pessoais e da habitação, com o intuito de atribuir aos rurícolas a responsabilidade pela prevenção de "[...] doenças e superstições, habitua-os a procurar as entidades oficiais ou particulares de saúde, crédito instrução etc, incentiva-lhes o gosto estético e higiene para construção da morada e interior da mesma” (Pascale, 1955, p. 6).

\section{“Ao fim e ao cabo": propagando um modelo de desenvolvimento...}

Uma das principais orientações da CNER, desde suas origens, era a formação de professoras "missioneiras 3 " como elemento de cooperação indispensável para a organização e o desenvolvimento das comunidades rurais. Para tanto, procedimentos educativos específicos foram adotados com o intuito de formar uma mentalidade comunitária e associativa nas localidades campesinas, com vistas, principalmente, a modificar culturas e a frear o fluxo migratório brasileiro intenso do meio rural para o meio urbano, bem como atribuir às comunidades a responsabilidade pela solução de seus "males".

A campanha levada "ao fim e ao cabo" pela CNER constituiu, portanto, uma experiência projetada com finalidades específicas de modificação do meio rural, estímulo ao consumo e submissão aos princípios do capital, além da finalidade explícita de desresponsabilizar o poder público dos encargos das políticas de melhoria do meio rural.

3 Missão é uma experiência que implica contato. No caso das professoras missioneiras formadas ou treinadas na CNER, eram elas que deveriam ir ao encontro dos habitantes da comunidade, propagando e divulgando informações a respeito das quais os rurícolas pouco ou nada conheciam, a exemplo, o crédito rural, Sociologia rural, sanitarismo rural, entre outras. 
Por meio das ações educativas, como círculo de estudos, trabalho de campo, debates, mesas redondas, conferências e, em menor escala, projeções de filmes, cujas temáticas abordavam organização das comunidades e técnicas de missão rural, extensão agrícola, sociologia e sanitarismo rural, noções de Psicologia Educacional e Pedagogia, cooperativismo, industrias, crédito rural, entre outros tópicos e abordagens, a CNER atuava no meio rural, incentivava a liderança local e a juventude a adotarem novas formas de vida frente a realidade e ao mundo do trabalho que convinha ao capitalismo em expansão no Brasil.

Propagando a valorização do meio e o preparo da juventude para dotá-la de conhecimento e disposição para se integrar às atividades comunitárias, a CNER promoveu o treinamento de professoras leigas rurais, nos Centros de Formação, nos Cursos Normais Rurais ou Cursos Regionais, de modo a doutriná-las/doutriná-los para a atuação no meio rural com a função intrínseca de difundir conhecimentos e promover a aceitação e receptividade de programas e projetos propostos pelo governo, pelas empresas e de novas formas de consumo que se alastravam pelo meio rural.

Com isso, as práticas "educacionais" alastradas pela CNER difundiram um "modelo" de desenvolvimento que interessava a determinados grupos dominantes agroindustriais brasileiros. Munindo-se de uma campanha educacional para modificação do meio rural, de seus costumes e cultura, a campanha empreendida contribuiu para ampliar a aculturação da população nas localidades atendidas, colaborando para a desapropriação da terra em posse de comunidades tradicionais, de comunidades ribeirinhas e campesinas, do conhecimento, da cultura e da identidade que possuíam.

Em suma, a CNER cooperou para expropriar saberes das comunidades campesinas, o que tornou suas propriedades alvos de desígnios do capital, preparando as comunidades para uma pretensa "modernização da agricultura" e para o consumo acelerado de bens, serviços e do crédito rural "necessários à melhoria" do meio no qual viviam, incutindo-lhes uma pretensa e apropriada visão de educação rural como queriam os Ministérios da Educação, da Saúde e da Agricultura brasileiros. 


\section{Referências}

ARREGUY, Colombo Etienne. A Campanha Nacional de Educação Rural (CNER). Suas origens, sua vida e seus trabalhos desde 1950 ao $1^{\circ}$ semestre de 1959. Revista Campanha Nacional de Educação Rural. Centro de Informação e Biblioteca em Educação - CIBEC/INEP. Ano 6, no 8, 1959, p. 14-58.

BARREIRO, Iraíde Marques de Freitas. Educação rural capitalista: a contradição entre a educação modernizadora e a educação de classe popular na Campanha Nacional de Educação Rural. Dissertação (Mestrado). Faculdade de Educação, Universidade Estadual de Campinas, 1989.

BERGSTRÖM LOURENÇO FILHO, Manoel.A formação de professores da Escola Normal à Escola de Educação. Brasília: Inep/MEC, 2001.

BRASIL. Mensagem de Getúlio Vargas ao Congresso Nacional. Apresentada pelo Presidente da República por ocasião da abertura da sessão legislativa de 1951. Rio de Janeiro, 15 de março de 1951, p. 102-103. Disponível em: http://brazil.crl.edu/bsd/bsd/u1330. Acesso em: 5 de jun. 2020.

BRASIL. Decreto no 38955 de 27 de março de 1956. Dispõe sobre a Campanha Nacional de Educação Rural (CNER). Disponível em: https://www. diariodasleis.com.br/legislacao/federal/95960-dispue-subre-a-campanha-nacional-de-educauuo-rural-cner.html. Acesso em: 15 de dez. 2020.

CLEOPHAS, João. Relatório das Atividades do Ministério da Agricultura em 1954. Rio de Janeiro, Serviço de Informação Agrícola, 1955.

CONCEIÇÃO, Diamantina Costa. Qual o Melhor Processo para a Dinamização e o Desenvolvimento Cultural e Econômico dos Municípios Brasileiros. Revista Campanha Nacional de Educação Rural. Centro de Informação e Biblioteca em Educação - CIBEC/INEP. Ano 1, no 1, 1954, p. 5 - 25. 
FERREIRA, Nilce Vieira Campos; LIMA, Sandra Cristina Fagundes. Uma formação intelectual e social conveniente [...], formação de professores rurais (Brasil, 1942-1963). Cadernos de História da Educação, v.19, n.3, p. 942960, set-dez. 2020. Disponível em: http://www.seer.ufu.br/index.php/che/article/view/56867. Acesso em: 21 fev. 2021.

FERREIRA, Nilce Vieira Campos; SOUZA, Cleicinéia Oliveira; PRADO, Fernanda Batista do. História da Educação no Centro-Oeste e Norte Brasileiros entre o ofício e a missão: formação de professoras normalistas e missioneiras rurais. Curitiba: Appris, 2019.

FERREIRA, Nilce Vieira Campos. Economia Doméstica: ensino profissionalizante feminino no Triângulo Mineiro (Uberaba/MG-1953-1997). Jundiaí, Paco Editorial, 2014.

GAGO LOURENÇO FILHO, Francisco. A valorização das zonas rurais pela educação da liderança local. Revista da Campanha Nacional de Educação Rural, Brasília, anos 6/7, v. 9, 1959, p. 17-24.

LEITE, Sérgio Celani. Escola rural: urbanização e políticas educacionais. São Paulo, Cortez, 1999.

LIMA, Sandra Cristina Fagundes. Escola Rural: História, Memória e Representações. Cadernos de História da Educação, n. 3, jan./dez, 2004, p. $27-37$. Disponível em http://www.seer.ufu.br/index.php/che/article/view/345/350. Acesso em 21 fev. 2021.

MENDONÇA, Sônia Regina. Ensino agrícola e influência norte-americana no Brasil (1945-1961). Tempo [online]. 2010, vol.15, n.29, p.139165. Disponível em: http://www.scielo.br/scielo.php?script=sci_arttext\&pi$\mathrm{d}=\mathrm{S} 1413-77042010000200006 \& \operatorname{lng}=$ en\&nrm=iso. Acesso em: 03 de mar. 2021.

PASCALE, Carlos. Sistematização do Trabalho da CNER e Planejamento de suas Atividades para 1955. Revista da Campanha Nacional de Educa- 
ção Rural. Centro de Informação e Biblioteca em Educação - CIBEC/INEP. Ano 2, no 2, 1955, p. 5-13.

PROST, Antoine. Doze lições sobre a história. Belo Horizonte, Autêntica Editora, 2008.

RAMOS, Rui. Governo Rural. Revista da Campanha Nacional de Educação Rural, Brasília, 1954, ano 1, v. 1, p. 75-112.

RCNER. Campanha Nacional de Educação Rural. Regulamento. Revista Campanha Nacional de Educação Rural. Centro de Informação e Biblioteca em Educação - CIBEC/INEP, Brasília, ano 6, no 8, 1959, p. 25-29.

RCNER. Campanha Nacional de Educação Rural. Regulamento. Revista da Campanha Nacional de Educação Rural. Centro de Informação e Biblioteca em Educação - CIBEC/INEP, Brasília, ano 6, v. 8, 1959, p. 107.

ROMERO, Nelson. Campanha Nacional de Educação Rural. Relatório apresentado ao Ministro da Educação. In: NÓBREGA, Wandick Londres da (org.). Enciclopédia da Legislação de Ensino. Departamento Nacional de Educação do Ministério de Educação e Saúde. Vol. 2. Rio de Janeiro, 1954, p.184-193.

SALGADO, Clóvis. Ata de Instalação do $1^{\circ}$ Curso de Treinamento de Professôres Rurais do Centro Regional de Educação de Base (CREB), Revista da Campanha Nacional de Educação Rural, Rio de Janeiro, v. 3, n. 4, p. 14-15, 1956.

SOUZA, Luiz Rogério. A missão rural, fator de recuperação do homem do interior. Revista da Campanha Nacional de Educação Rural, Rio de Janeiro, v. 1, n. 1, p. $42-56,1954$.

TELES, José Francisco de Sá. A escola rural e seus problemas. Revista da Campanha Nacional de Educação Rural. Ministério da Educação. Arquivo Histórico do INEP. ANO 1. Jul. 1954. p. 57-74. 
TERRISE, André. O sentido humano da Educação de base. Tradução de Maximiro Nogueira de Medeiros. Revista da Campanha Nacional de Educação Rural, Brasília, ano 3, v. 3, 1956, p. 164-170.

VARGAS, Getúlio. Mensagem de Getúlio Vargas ao Congresso Nacional. Apresentada pelo Presidente da República por ocasião da abertura da sessão legislativa de 1951. Rio de Janeiro, 15 de março de 1951, p. 102-103. Disponível em http://brazil.crl.edu/bsd/bsd/u1330. Acesso em: 05 jun. 2020.

UNESCO. Recommandations 1934-1977. Conference Internationale do l'education. France: Imprimerie de la Manutention à Mayenne, 1979. Disponível em: http://www.unesco.org/education/information/nfsunesco/pdf/34_77_E.PDF. Acesso em: 03 de mar. de 2021. 


\section{VÍRUS, TELAS E JANELAS: ENSINO REMOTO, MÍDIAS E ESTUDOS CULTURAIS}

Fernanda Amorim Accorsi

Samilo Takara

\section{Introdução}

Desde o início do ano de 2020, com a emergência dos primeiros casos de contaminação e as mortes causadas pelo vírus SARS-CoV-2 no Brasil, a instabilidade está presente em diferentes cenários da vida contemporânea. A Educação passa por instabilidades que desequilibram o exercício do ensino presencial, que não se faz possível neste momento. O chamado COVID-19 exigiu, como medida de proteção, a contenção e o cuidado com a população, as ações de distanciamento social são orientações estratégicas para diminuir os casos de infecção.

O objetivo deste empreendimento teórico é problematizar o Ensino Remoto como alternativa para as condições contemporâneas da Educação Básica e do Ensino Superior sobre as necessidades de manter e contribuir para a formação de discente dos níveis de ensino, mas também pensar sobre os percalços, as dificuldades e as condições possíveis de sua efetivação.

A concretização do Ensino Remoto ocorre com as portarias 343/2020/ MEC e 544/2020/MEC que autorizam, em caráter excepcional, a substituição de aulas presenciais por aulas ofertadas por meio de mídias digitais para a continuidade das formações para o Ensino Superior. Em diferentes lugares, Estados e Municípios optam por ofertar as aulas remotas para estudantes de diferentes períodos como uma estratégia para a manutenção das atividades de ensino.

Diante deste cenário, buscamos uma reflexão teórica e metodológica voltada para pensar a Formação Docente neste contexto e a relação direta entre Mídias e Educação para problematizarmos as demandas e as possibilidades de um ensino remoto no contexto que vivemos. Desse modo, inscritos nas perspectivas dos Estudos Culturais, essas discussões perpassam a compreensão 
de Educação, as possibilidades e os limites para pensar as contribuições das mídias e o diálogo para uma formação docente que analise as condições deste tempo para o uso das tecnologias de comunicação e informação (TICs) como espaços escolares/educativos.

Em outros momentos, discutimos sobre o reconhecimento da mídia como um território discursivo que nos educa sobre modos de ser, estar e agir (Accorsi, 2018; Takara, Teruya, 2013; Takara, 2013). A compreensão que apresentamos neste primeiro momento é que a mídia é um espaço que nos educa em diferentes perspectivas e possibilidades. Espaços individuais e coletivos constituem lugares para o diálogo e para momentos de ensino e aprendizagem que não são necessariamente escolares, mas certamente são educativos.

As mídias nem sempre se autointitulam educativas, mas contribuem para a composição de concepções de certo e errado, adequado e inadequado, apropriado e inapropriado, dicotomias que formam comportamentos e pensamentos. No entanto, também abrem margem para a formação de agentes questionadores/as da realidade, das certezas e das verdades, porque não possuem o monopólio do saber, em razão dos sujeitos serem reflexivos/as e ativos/ as diante dos conhecimentos midiáticos.

Entretanto, o ano de 2021 em que este texto está inscrito, abre outra configuração territorial para as mídias, que é transformar artefatos midiáticos em espaços escolares, sistematizados e com uma proposta específica de construção do conhecimento. Santos (2020) explica: "[e]nsino remoto não é EAD e muito menos Educação Online”, uma vez que os desdobramentos escolares se dão com um desenho didático emergencial por meio de aulas síncronas e assíncronas, "[...] permite encontros afetuosos e boas dinâmicas curriculares emergem em alguns espaços, rotinas de estudo e encontros com a turma são garantidos no contexto da pandemia”.

Essa cisão da educação no espaço escolar e não escolar é complexa e, neste momento em que se discute a educação remota como os usos de artefatos midiáticos para a mediação das práticas de ensino e das situações de aprendizagem, temos cada vez menos a nítida definição do que seria escolar e do que 
seria não escolar. Sibilia (2012) nos diz da dificuldade de manter a delimitação das paredes com uma comunidade escolar que vive conectada em rede.

Agora a rede é proposta como espaço escolar. Entretanto, as condições de produção da educação contemporânea nos remetem a pensar sobre quais as demandas, os objetos do conhecimento, as práticas pedagógicas possíveis e suportadas pelas mídias no que tange à educação escolar. Incomoda-nos que, antes, era discutida a ideia de que a escola deveria conviver com as mídias e os discursos presentes em seus espaços, agora ganham outros contornos porque não é mais a mídia que invade o espaço escolar, mas a escola que se propõe a instalar-se nas redes e nas telas de modo oficial e institucionalizado.

As subjetividades hoje interpeladas pela escola - ou até pela universidade - já não são as de outrora: aquelas cinzeladas de forma sucessiva sob a moral do regulamento. $\mathrm{O}$ mercado e a mídia, assim como os ritmos de vida característicos da contemporaneidade, levam à composição de outros modos de ser, cujas operações básicas diferem em grande medida daquelas regidas pela lei universal ou pela figura centralizada e hierárquica do Estado nacional. Assim, quando o aparato escolar solicita a esses novos corpos que ponham em prática tais habilidades e recursos, o desajuste se faz evidente. Por isso, nesse novo contexto, o desafio não consiste em transgredir regras demasiadamente duras e cerceadoras das liberdades individuais, mas em enfrentar o problema de que elas não existem ou que tenham se tornado impotentes: surge a necessidade desesperada de "instituir" algo para que se produza um diálogo, inclusive entre mestres e alunos. Ante o enfraquecimento da aparelhagem legal, as regras - sempre precárias e temporárias têm que ser negociadas e enunciadas em cada situação, em vez de partirmos da base de que existem normas implícitas que deveriam ser seguidas por unanimidade (Sibilia, 2012, p. 99).

Embasados por essa problemática e pelo cenário da educação em condições remotas, discutimos outra perspectiva que, nesse momento, se faz necessária para o campo da Educação que é a proposição de assumir as mídias como espaços escolares. Assim, outras questões se fazem relevantes neste momento como problematizar não apenas o caráter pedagógico da mídia, por meio das 
análises das pedagogias culturais, como os Estudos Culturais atuam, mas, também, pensar em uma mídia-escola.

E, neste contexto de produzir um diálogo acerca das dimensões educativas e escolares, se faz necessário refletir sobre as necessidades da educação escolar, as dificuldades e suas estruturas e, ao propor uma ação pedagógica midiática, ressignificar os modos como pensamos a educação e as mídias na contemporaneidade. Uma mídia-escola não segue as ideias de usos de filmes ou materiais para ensinar, apenas, mas o reconhecimento de que a construção de práticas de ensino e de momentos de aprendizagem devem ser realizados no território midiático.

Desse modo, retomamos as contribuições lançadas anteriormente para os estudos de mídias na educação para, neste momento em que se discute o cenário contemporâneo e a necessidade de uma educação escolar que ocorra mediada pelas tecnologias, dar início às propostas de mídia-escola. Para tanto, é relevante que questionemos para além de uma proposição dos modos de usar a mídia, quem pode usá-la, de que modos e para quais finalidades.

Diferentes, desiguais e desconectados? Formular os modos da interculturalidade em chave negativa é adotar o que sempre foi a perspectiva do pensamento crítico: o lugar da carência. Mas colocar-se na posição dos despossuídos (de integração, de recursos ou de conexões) ainda não é saber quem somos. Imaginar que se podia prescindir deste problema, foi, ao longo do século $\mathrm{XX}$, o ponto cego de muitos campesinistas, proletaristas, etnicistas ou indianistas, de feministas que suprimiam a questão da alteridade, de subalternistas e quase todos aqueles que acreditavam resolver o enigma da identidade afirmando com fervor o lugar da diferença e da desigualdade. Ao ficar deste lado do precipício, quase sempre se deixa que outros - deste lado e daquele - construam as pontes. As teorias comunicacionais nos lembram que a conexão e a desconexão com os outros são parte da nossa constituição como sujeitos individuais e coletivos. Portanto, o espaço inter é decisivo. Ao postulá-lo como centro da investigação e da reflexão, estas páginas buscam compreender as razões dos fracassos políticos e participar da mobilização de recursos interculturais para construir alternativas. (Canclini, 2007, p. 30-31, grifo do original). 
Compreender os desajustes propiciados pela relação entre redes e escolas (Sibilia, 2012) e a construção de alternativas (Canclini, 2007) se rarefaz na postura de assumir que a tecnologia e os acessos às redes de informação e comunicação não são amplos no território brasileiro. Entretanto, também não podemos dizer que a escola é um espaço acessível para todas e todos. Louro (1997, p. 57) nos diz que a escola entende de desigualdade, de diferença, porque ela é parte desse sistema de exclusão. É relevante compreendermos que a escola "[...] se incumbiu de separar os sujeitos- tornando aqueles que nela entravam distintos dos outros, os que a ela não tinham acesso".

Desse modo, alinhavar a crítica de Louro (1997) ao ideal constitucional que garante em seu Art. 208, § $1^{\circ}$ "O acesso ao ensino obrigatório e gratuito é direito público subjetivo" (Brasil, 1988) exige a discussão de que a escola física e presencial não se realiza de forma plena em todos os espaços do país. Ao mesmo tempo, existem aquelas e aqueles que não têm acesso de qualidade à internet e aos aparelhos técnicos e tecnológicos que garantam acesso à mídia-escola. Embora não possamos garantir que são as mesmas pessoas que não têm acesso ao presencial e ao remoto, podemos refletir que nas duas instâncias de aprendizagem há processos excludentes que precisam ser levados em consideração nas problematizações sobre educação.

Essas questões vinculadas ao acesso e à permanência são relevantes porque a motivação de mostrar que a educação escolar presencial não era acessada por todas e por todos não exime que qualquer proposta de formação educativa se empenhe no acesso geral de estudantes. Assim, o primeiro percalço para pensar nas condições de educação de forma remota é levantar as possibilidades de acesso e de qualidade das redes e suportes tecnológicos que garantam o acompanhamento das atividades de ensino e oportunizem situações de aprendizagem.

Em outra direção, percebemos que "[a] midiatização afasta, esfria, e, ao mesmo tempo, a interconectividade proporciona sensações de proximidade e simultaneidade" (Canclini, 2007, p. 216). Sensações como a distância e a aproximação são presentes na discussão sobre usos de internet e artefatos midiáticos. Gumbrecht (2010, p. 13), ao analisar a presença, diz que esta é “[...] uma relação espacial com o mundo e seus objetos. Uma coisa 'presente' deve 
ser tangível por mãos humanas- o que implica, inversamente, que pode ter impacto imediato em corpos humanos".

A Educação que vivemos nestes tempos é realizada no contexto da presença, porque as aulas síncronas, as lives nas redes sociais exigem o comparecimento de pessoas envolvidas, em tempo real, na busca pelo saber. Entretanto, as tecnologias de informação e comunicação são profundamente alteradas nessas primeiras décadas do século XXI. Com a disseminação de aparelhos smartphones e a pluralização dos espaços com redes wi-fi e acessos por pacotes de dados, as redes sociais e as mídias digitais delineiam outros contornos sobre os corpos, as vidas e as práticas que inscrevem os discursos das mídias contemporâneas.

Mondzain (2015) trata dos impactos das imagens que são disseminadas nas diferentes mídias e como elas produzem nossas visualidades. Nossas relações estão vinculadas em espaços presenciais e nos usos das tecnologias desde o desenvolvimento das correspondências, os usos das prensas de tipos, a popularização do rádio e da televisão. Esses usos mudaram nossos modos de ver e de estar presente.

Os hardwares tornam-se obsoletos quase tão rapidamente quanto os sistemas operacionais precisam ser reinstalados, enquanto softwares específicos ditam o ritmo das atualizações e a pulsação dos upgrades. Isso coloca os usuários em luta contra a noção singular de que mesmo o passado recente se afasta mais rápido do que visualizamos o futuro, ou compreendemos o presente (Elsaesser, 2018, p. 38).

As mudanças tecnológicas geram outras formas de comunicação e de interação, mas também abrem possibilidades para pensarmos em estratégias e condições para a realização de atividades pedagógicas e escolares com suportes midiáticos. Desse modo, os recursos interferem nas possibilidades de realização das atividades, assim como as condições de acesso interferem nos modos de interação, de aprendizagem e de desenvolvimento crítico diante do objeto do conhecimento.

Para além desses elementos que são da ordem de acesso à internet e aos artefatos midiáticos, existem as condições humanas e pedagógicas necessárias ao processo de ensino em contexto midiático. Desse modo, a proposição de 
uma problemática acerca das possibilidades de se escolarizar as mídias também lida com elementos como as condições de estudo que estão disponíveis para os/as estudantes, as necessidades espaciais e de infraestrutura no espaço doméstico e as questões de formulação pedagógica deste trabalho.

A dimensão pedagógica e as condições de ações educativas que são ofertadas para pessoas que estão nos espaços domésticos também precisa considerar, junto aos elementos apresentados até o momento, as maneiras e as possibilidades de perceber a mídia como espaço pedagógico. Para problematizar ações educativas nos espaços midiáticos também é necessário reconhecer que a mídia educa. Ao compreendermos essa condição educativa das mídias, elencamos elementos que precisam de nitidez para uma proposta de educação remota.

Sibilia (2012) trata de uma mudança na dimensão da lógica escolar que abre oportunidades para outros modos de pensar e de agir acerca das proposições pedagógicas. A proliferação das oportunidades de acesso às redes, as interações entre as pessoas para atividades que são realizadas em dispositivos e com conexão com a internet têm gerado outras possibilidades de ação para uma educação na contemporaneidade.

Redimensionar a compreensão do que é educativo e pedagógico corrobora para a compreensão da contribuição da educação escolar, mas também a pluralização de propostas de ensino e as pedagogias culturais que multiplicam as maneiras de compreender o mundo, o outro e a nós. "Redes educativas são espaços plurais de aprendizagem" (Santos, 2019, p. 35), em razão da internet não ser usada como mero repositório de informações, mas sobretudo como ambiência de iniciativa do alunado, que, mesmo diante do estranhamento da aprendizagem, reinvente formas de acessar à internet, mas também de aproximar-se do conhecimento.

Assim, os conhecimentos e as informações participam de um grupo de ações e de formas que situam as representações e as possibilidades de agir, as quais inscrevem a educação em outros contextos.

Com a ênfase nas tecnologias, o saber é diluído na massa informacional que circula na sociedade, sendo exteriorizado e, ao mesmo tempo, acessível 
e presente na vida das pessoas de variadas maneiras, operando em conjunto com artefatos culturais que tem contribuído para disseminar os saberes socialmente mais legitimados (Camozzato, 2012, p. 25).

Desse modo, os conhecimentos e as práticas sociais contemporâneas são disponibilizados por diferentes tecnologias de informação e comunicação que foram alterados em suas produções e na disseminação do acesso desses artefatos culturais. Elsaesser (2018, p. 74) explica que "[...] as tecnologias de som e visão passaram por uma mudança decisiva de paradigma, a qual requer um novo mapeamento da imagem em movimento".

Ao propor uma arqueologia das mídias e estudar o cinema, o autor produz estratégias que corroboram para compreendermos que a mídia não está apenas na posição de suporte dos conteúdos e das informações, como também interfere diretamente nos modos de acesso, uso e produção de comunicação na contemporaneidade. Retomar essa perspectiva é uma forma de pensar como os suportes midiáticos são constituintes das práticas contemporâneas.

Esse entendimento dialoga com os estudos de McLuhan (2007) acerca dos meios de comunicação como extensões do corpo humano. O pensador canadense explica que "cada produto que molda uma sociedade acaba por transpirar em todos e por todos os seus sentidos" (Mcluhan, 2007, p. 37). Assim, as sociedades foram alteradas pelos meios de comunicação e as tecnologias que produziram. Ao acompanharmos essa análise do pensador, também compreendemos que para além dos conteúdos e das mensagens, o próprio uso da mídia nos educa.

Exemplos são crianças que ainda não foram alfabetizadas, mas que têm acesso aos tablets e celulares conseguirem, por meio dos movimentos nas telas, encontrar jogos e animações para assistir, brincar e consumir essas representações. O uso de telas táteis mudou nossa relação com as teclas e as teclas mudaram nossas relações com as manivelas e essas mudaram nossas relações com o mundo, com o outro e conosco.

As transformações das tecnologias mostram também os aspectos pedagógicos que elas inscrevem em nossas formas de ser, de estar e de agir no mundo e, assim, interferem diretamente na cultura e nas práticas educativas. 
Kellner (2001, p. 52-53) trata da necessidade de desconstruir a separação entre cultura e comunicações que é “arbitrária e rígida”. Na compreensão do teórico, esses campos confluem porque "não há comunicação sem cultura e não há cultura sem comunicação”. Assim, como afirma Freire (1996, p. 98) “sem ele [o diálogo], não há comunicação e sem esta, não há verdadeira educação”.

Reconhecer a inexatidão da separação entre cultura e comunicação, entre comunicação e educação é compreender também que estes campos somam olhares complexos para pensar na vida contemporânea. Os estudos culturais como campo teórico-político nos auxiliam nessa tarefa por oportunizar o debate, a desnaturalização e o reconhecimento dos aspectos pedagógicos, comunicativos e culturais que estruturam as relações, os processos e os conhecimentos.

Este campo direciona que a percepção é, entre outras coisas, interpretação, cuja essência perpassa pela produção de significado do sujeito, logo, as mídias sugerem oportunidades de valoração das imagens, dos saberes, das informações exibidas, portanto, o ato de ver é, sobretudo, um processo ativo e criativo do momento da aprendizagem (Kellner, 2001). Em outras palavras, ao assistir às aulas do Ensino Remoto, o sujeito não apenas assiste, mas elabora, cria e estabelece significados criados por ele/a, a partir dos processos incentivados pelo/a professor/a.

Portanto, as contribuições dos estudos culturais nos permitem pensar em como a ideia de uma mídia-escola precisa ser problematizada para além da compreensão do uso de mídias que seria a implantação de uma sala de aula virtual. Sibilia (2012) trata de como as subjetividades contemporâneas estão imersas em relações midiáticas que perpassam outras linguagens diferentes daquelas da escola como instituição moderna.

Entre essas linguagens que povoam e constroem nossas representações, as imagens estão construindo outras maneiras de se relacionar e produzir sentidos, tal como analisa Mondzain (2015). Desse modo, Kellner (2001, p. 331) explica que essa cultura que vivemos está vinculada a uma variedade de "posições de sujeito" que são apresentadas em diferentes contextos, cenas, exposições, reportagens. As mídias sociais são exemplos do uso das imagens e dos 
modos de comunicar alterados de uma perspectiva que antes estava centrada na escrita e hoje se desloca para a imagem.

Entre as séries de ações que percebemos serem desenvolvidas no contexto do distanciamento social, as lives, falas mediadas por câmeras profissionais ou pelas embutidas em aparelhos como celulares e notebooks têm se tornado estratégias de contato e de disseminação de informações em grupos. Silverstone (2005, p. 17) explica que a mídia deve ser compreendida como um processo que é social.

Entender a mídia como um processo - e reconhecer que o processo é fundamental e eternamente social - é insistir na mídia como historicamente específica. A mídia está mudando, já mudou radicalmente. $\mathrm{O}$ século $\mathrm{XX}$ viu o telefone, o cinema, o rádio, a televisão se tornarem objetos de consumo de massa, mas também instrumentos essenciais para a vida cotidiana. Enfrentamos agora o fantasma de mais uma intensificação da cultura midiática pelo crescimento global da Internet e pela promessa (alguns diriam ameaça) de um mundo interativo em que tudo e todos podem ser acessados, instantaneamente (Silverstone, 2005, p. 17).

Compreender os usos das mídias contemporâneas nos auxilia a discutir as estratégias que podemos desenvolver na produção de uma relação pedagógica com as mídias. A proposta de midiatizar a escola também precisa discutir a escolarização da mídia sendo que esses artefatos tecnológicos não foram produzidos e não são utilizados como espaços educativos formais. Problematizar as condições educativas das mídias é uma das estratégias para discutirmos as possibilidades de uma mídia-escola.

\section{Mídia-escola: possibilidades pedagógicas}

Embasados pelas discussões que a área de Mídias na Educação levanta no debate para pensar as condições pedagógicas de usos das tecnologias de informação e comunicação, inventemos a lógica para pensar como a proposta de uma escolarização das mídias exige uma análise das complexidades formativas que são possíveis nas condições contemporâneas, tendo em vista as especificidades das mídias para a Educação. 
Pensar nessas especificidades é retomar que esses artefatos culturais não são criados, usados e propostos sob uma condição pedagógica. A educação pelas mídias não é uma experiência pensada pelos produtores de conteúdos de diferentes áreas do conhecimento comunicacional e midiático. Ao invés disso, a mídia trabalha com dimensões como o consumo, a exposição de imagens e discursos, a construção de perspectivas narrativas e a lógica de visibilidade.

A tela do cinema, a tela da televisão, a tela do computador também são janelas sintéticas, mostram o mundo sinteticamente, simplificam (porque recortam) o mundo dentro delas próprias. E o que significa sintetizar o mundo? Significa recriá-lo como brinquedo, domesticá-lo, torná-lo compatível com nosso pequeno e estreito raio de mobilidade. Significa trazer para perto, bem perto, tudo o que é distante. Significa trazer sem trazer, porque o que vem, vem traduzido, recortado, às vezes toscamente colorizado ou desodorizado, domesticado, processado, enfim, simplificado como resultado de um processo de abstração (só para recordar: a palavra 'abstração' é, em certa medida, sinônimo de 'subtração'). Tudo na medida de nossa própria preguiça e nos moldes de nossa incapacidade de saltar, de reagir, de protestar, de rejeitar, de ficar indignados, de nos virarmos de costas. Se o corpo está sedado, as janelas sintéticas têm de trazer um mundo ora exacerbado e histérico, com tons apelativos para nos despertar, ora sedativo, que não nos desperte do estado pré-comatoso em que colocamos nossos corpos nos depósitos de corpos, as cadeiras, sofás, bancos, assentos e poltronas (Baitello Junior, 2012, p. 52).

As metáforas de tela e janela que estão presentes no título deste texto, e que também inspiram as discussões de Baitello Junior (2012) corroboram para problematizarmos uma das funções da mídia que é a de exposição, de visibilidade e que, desde a mudança de paradigma com o acesso e a interação de usuários com os conteúdos - e, hoje, presente a produção e a disseminação de conteúdos que não são produzidos por profissionais de comunicação, mas por pessoas com acesso as tecnologias de informação e comunicação - e os formatos que indicam nas telas e nas janelas a oportunidade de (re)conhecer experiências, informações e produzir sentidos. 
"Observando a imprensa, a televisão e o cinema, a propaganda e a moda, as igrejas, os regulamentos jurídicos e educacionais, perceberemos que todos lançam mão, dentro de suas formas específicas de discurso, de diferentes códigos, símbolos e recursos no processo de constituição dos sujeitos” (Louro, 2014, p. 104). Portanto, a dimensão educativa das mídias nos ensina sobre práticas de consumo, produções culturais e artísticas, informações jornalísticas, apelos publicitários, representações que inscrevem na sociedade e na cultura modos de ser e de agir. Ao pensarmos em usos pedagógicos da mídia, é necessária a revisão das posições que as mídias contemporâneas são vistas, utilizadas, produzidas e consumidas na contemporaneidade.

Silverstone (2005) trata sobre as transformações estéticas, culturais e as necessidades de estudos de mídias que problematizem nossas relações com as condições de produção de sentidos e significados que inscrevem nossas relações na contemporaneidade. Pensar em uma mídia-escola e nos usos de recursos com redes sociais, com plataformas de suporte e distribuição de vídeos, áudios, textos e imagens também é propor uma outra posição à mídia.

Se antes discutimos as possibilidades de territorialização das mídias por discursos que são pedagógicos e que educam outros modos de ser, estar e agir no mundo, as provocações de pensar um ensino remoto atuam em uma dimensão inversa. Ao invés de pensar nas dimensões pedagógicas dos discursos e das imagens midiáticas, a exigência de uma proposta de ensino remoto trata também da escolarização das mídias (Takara; Teruya, 2013; Takara, 2013).

Para tal ação, é necessário pensar como as estruturas escolar e midiática são diferentes em suas propostas de organização, sistematização e disseminação de informações. O comprometimento dessas estruturas institucionais, suas práticas de produção e de diálogo sobre as formas de agir e de ser no mundo é, entre outras coisas, reconhecer os limites que estão inscritos nas condições de produção de uma escolarização das mídias contemporâneas.

Nossas escolas se tornaram ao longo dos séculos instituições mestras em domesticar a inquietude natural de nossas crianças. Anos e anos são gastos para uma lição magna: ensinar a sentar e permanecer sentado, 
preferencialmente com as mãos também em repouso. Esse passa a ser o pressuposto maior de qualquer outro conteúdo de aprendizagem (Baitello Junior, 2012, p. 138).

A compreensão do autor também dialoga com a perspectiva do que é o papel de uma educação na contemporaneidade e, ao mesmo tempo, com a necessidade de debates que perpassam as diferentes produções de conteúdos e de áreas que compõem os conhecimentos da formação docente contemporânea. Os conhecimentos psicológicos, sociais, culturais, pedagógicos, didáticos, metodológicos são produzidos para um pensamento sobre a educação como formação presencial e formam pedagogos e pedagogas, bem como as diferentes especificidades das licenciaturas para uma atuação exclusivamente presencial nas salas de aula.

Ao pensarmos sobre uma dimensão de ensino remoto e da proposta de uma escolarização das mídias, é necessária rever a atenção dada às relações entre ensino e tecnologias digitais e/ou educação para/com as mídias, elencados nos currículos e nas formações de professoras e professores. Para além disso, os estudos das mídias como artefatos culturais que corroboram para formas de produção e exposição de conteúdos que podem contribuir com uma educação contemporânea.

[...] a criança contemporânea teria abandonado sua condição de inepto a ser protegido e educado, para se tornar um consumidor a ser conquistado e com o qual se deve aprender. Poderíamos dizer que deixou de ser um aluno, mero destinatário da transmissão de um saber que o nutriria e iluminaria em sua futura trajetória cidadã, para se encarnar num ativo prossumidor ou produsuário, recorrendo-se aqui a neologismos surgidos da confluência entre termos como produtores, usuários e consumidores, em inglês, cuja aplicação vem se expandindo para outros campos. Nos últimos anos, o uso dessas expressões penetrou tanto nos discursos empresariais quanto em certos setores da pesquisa acadêmica, para fazer referência aos novos tipos de consumidores ou usuários "ativos" que contribuem com seus aportes para alimentar o acervo disponível na internet, por exemplo, embora sua utilização também perpasse práticas artísticas, jornalísticas, comerciais, educativas e políticas que ultrapassam as redes informáticas (Sibilia, 2012, p. 123). 
Nos diferentes territórios das redes sociais e da produção de conteúdo, crianças e adolescentes cada vez mais estão presentes em plataformas de produção de imagens, vídeos e textos que tratam das experiências do agora. Entretanto, a dimensão da formação de professoras e professores e as escolas não discutem sobre essas alterações pensando no diálogo com as subjetividades contemporâneas, mas sobre a docilização e o adestramento de corpos que estão em movimento e já não se satisfazem com a lógica escolar que ainda estrutura a instituição educativa.

A proposta de escolarização das mídias discute os efeitos das produções e do consumo das mídias na construção subjetiva, na dimensão cultural, nas práticas sociais e nos modos como crianças e adolescentes lidam com as mídias e seus efeitos de velocidade, de produção de sentidos e a instabilidade das redes, seja para a manutenção do acesso, seja a velocidade de disseminação de conteúdo ou, ainda, na possibilidade de ser um/a produtor/a de conteúdo. A escolarização das mídias perpassa, ainda, pela promoção de autorias digitais, cujas práticas são inventivas e participativas, unindo docentes e discentes na confecção de aulas, atividades e produção do saber (Santos, 2019; Accorsi, 2018).

Vemos, portanto, que a referida escolarização trata de um envolvimento com as mídias, em que elas se tornem espaços de criações educativas, que podem ser compartilhadas, socializadas e repercutidas. Assim, o alunado percebe que a produção realizada em determinada aula e/ou componente curricular faz parte do repertório midiático que ele/a próprio/a ajudou a construir.

As ações pedagógicas nem sempre são desenhadas para contextos midiáticos e, desse modo, pensar em uma escolarização da mídia é recordar que o potencial das tecnologias de informação e comunicação é o compartilhamento, o diálogo, a produção de representações e as problematizações os impactos dessas tecnologias. Ao invés da prática de condenar os usos das redes sociais e os espaços de produção de conteúdo, uma mídia-escola precisa desenvolver uma análise dos sistemas de produção e disseminação de mídias.

Chamar a atenção, para não sucumbir: esse é o imperativo, quase categórico, que todos seguem, ainda que cada um à sua maneira. [...] Não ser percebido 
significa estar de fora, e estar de fora é como estar morto em um corpo vivo

- incompatível com a dignidade humana (Türcke, 2010, p. 59).

Este imperativo convive com a escola e é representado pelas posições das carteiras, pelos uniformes, pela customização das salas de aula, pelas atividades cumpridas como horas complementares que beiram à massificação. As críticas às mídias sobre a massificação de crianças e adolescentes parecem não reconhecer que a escola também tem esse potencial. É relevante, portanto, ampliar a pergunta de "que fazem as mídias?" para "o que fazemos com elas na educação?”. Uma mídia escola objetiva a criação e o diálogo sobre produção e análise de conteúdos como condição dos usos das mídias na função educativa.

Além dessa característica, a capacidade de análise e de condições de verificar as possibilidades e os limites dos usos das informações das redes, a discussão sobre direitos autorais, a problematização sobre direitos de imagem e a ideia de proteção desses direitos para crianças e adolescentes devem fazer parte do cenário de debate que envolvem a proposta de uma escolarização das mídias.

\section{Considerações finais}

Acesso, condições objetivas, condições subjetivas, efeitos das mídias nas subjetividades e nas produções de crianças e adolescentes precisam estar presentes na dimensão curricular da formação de professoras e professores que também precisam compreender que condições e que possibilidades as mídias oferecem e os elementos complexos e possibilidades interessantes nos usos das tecnologias de informação e comunicação.

O estatuto pedagógico que constituímos nas escolas com base nas informações para uma educação presencial precisa ser discutido antes de uma proposta de ensino remoto porque a proposta de educação da escola está vinculada à modelos e ideias de indivíduo, sujeito, cidadão que não corroboram com as potencialidades que as mídias oferecem na problematização das ações pedagógicas e culturais possíveis nos meios de comunicação.

Exemplo disso é a cultura conteudista que faz parte das propostas de decorar informações que podem ser livremente acessadas nas redes. Outro ele- 
mento é a falta de ensino sobre checagem de informações e conteúdos que precisa se tornar uma discussão presente nas escolas e que transforme a prática do professor e da professora em uma dimensão de orientação de situações de aprendizagem diferente da posição de centralização dos conteúdos no papel docente.

Expostas essas condições, é necessário discutir que a proposta da escola construída no período da Modernidade como instituição que ensina o que se deve saber e como se deve saber precisa de problematização e outros estatutos são necessários para pensar em uma educação mediada por tecnologias de informação e comunicação. Pensar sobre os impactos das mídias e as formas de uso das subjetividades contemporâneas desses artefatos culturais é a necessidade deste tempo.

Assim, o Ensino Remoto precisa de uma formação docente diferente e de acesso a informações e debates que levem em conta as especificidades das mídias, suas características e usos na contemporaneidade. $\mathrm{O}$ quadro, a projeção multimídia e o uso de exemplos para alguém que centraliza o currículo nos/as alunos/as ou na figura docente são características de uma posição presencial de educação. A pergunta que precisamos responder é se conhecemos a mídia como território para pensar em indicações de um Ensino Remoto efetivo, que leve em conta as instabilidades de nossa época, bem como a plasticidade dos processos de aprendizagem.

A contenção do vírus nos exige olhar por janelas e telas. E, assim, o Ensino Remoto causa questionamentos sobre os limites e as possibilidades. Desde março de 2020, o exercício da docência é provocado a repensar porque os parâmetros são outros. Trata-se de promover o debate e problematizar a tensão educativa da Pandemia. Precisamos analisar seus efeitos, reconhecer suas dificuldades e pensar no que estamos fazendo quando ensinamos e aprendemos no contexto contemporâneo. 


\section{Referências}

ACCORSI, Fernanda Amorim. Professoras, levem mulheres à sala de aula: do jornalismo violento à prática pedagógica filógina. Tese. Programa de Pós-Graduação em Educação. Universidade Estadual de Maringá, 2018. Disponível em: http://www.ppe.uem.br/teses/2018/2018\%20-\%20 Fernanda\%20Accorsi.pdf. Acesso em: 21 mar. 2021.

BAITELLO JUNIOR, Norval. O pensamento sentado: sobre glúteos, cadeiras e imagens. São Leopoldo/RS: Unisinos, 2012.

BRASIL. Constituição: República Federativa do Brasil. Brasília/DF: Centro Gráfico, 1988.

CANCLINI, Néstor García. Diferentes, desiguais e desconectados. 2. ed. Trad. Luiz Sérgio Henriques. Rio de Janeiro: UFRJ, 2007.

CAMOZZATO, Viviane Castro. Da pedagogia às pedagogias: formas, ênfases e transformações. Tese. Doutorado em Educação. Universidade Federal do Rio Grade do Sul. Porto Alegre: UFRGS, 2012. Disponível em: https://lume. ufrgs.br/bitstream/handle/10183/49809/000837866.pdf? sequence=1\&isAllowed=y. Acesso em: 21 de mar. 2021.

ELSAESSER, Thomas. Cinema como arqueologia das mídias. Trad. Carlos Szlak. São Paulo: Sesc São Paulo, 2018.

FREIRE, Paulo. Pedagogia do Oprimido. São Paulo: Paz e Terra, 1996.

GUMBRECHT, Hans Ulrich. Produção de presença: o que o sentido não consegue transmitir. Trad. Ana Isabel Soares. Rio de Janeiro: Contraponto: Ed. PUC-Rio, 2010.

KELLNER, Douglas. A cultura da mídia: estudos culturais - identidade e política ente o moderno e o pós-moderno. Bauru: Edusc, 2001. 
LOURO, Guacira Lopes. Gênero, sexualidade e educação: uma perspectiva pós-estruturalista. Petrópolis: Vozes, 2014.

MCLUHAN, Marshall. Os meios de comunicação como extensões do homem. São Paulo: Cultrix, 2007.

MONDZAIN, Marie-José. Homo spectator: ver fazer ver. Lisboa: Orfeu Negro, 2015.

SANTOS, Edméa. EAD, palavra proibida. Educação online, pouca gente sabe o que é. Ensino remoto, o que temos. Notícias, Revista Docência e Cibercultura, agosto de 2020, online. Disponível em: https:/www.e-publicacoes.uerj. br/index.php/re-doc/announcement/view/1119. Acesso em: 08 de mar. 2021.

SANTOS, Edméa. Pesquisa-formação na cibercultura. Teresina: ADUFPI, 2019.

SIBILIA, Paula. Redes ou paredes: a escola em tempos de dispersão. Tradução: Vera Ribeiro. Rio de Janeiro: Contraponto, 2012.

SILVERSTONE, Roger. Por que estudar a mídia? 2. ed. Loyola: São Paulo, 2005.

TAKARA, Samilo. Gênero e Blog: problematizações dos discursos de professoras e professores. Dissertação. Programa de Pós-Graduação em Educação. Universidade Estadual de Maringá, 2013. Disponível em: http://www.ppe. uem.br/dissertacoes/2013\%20-\%20Samilo.pdf. Acesso em: 21 de mar. 2021.

TAKARA, Samilo; TERUYA, Teresa Kazuko. Mídia e Educação: problematizando noções de território midiático. Revista Textura. n. 27. Canoas/RS, 2013. Disponível em: http://www.periodicos.ulbra.br/index.php/txra/article/ view/955/735. Acesso em: 21 de mar. 2021.

TÜRCKE, Christoph. Sociedade excitada: filosofia da sensação. Trad. Antonio A. S. Zuin et al. Campinas/SP: Unicamp, 2010. 


\section{EIXO III - POLÍTICAS EDUCACIONAIS EM ANÁLISE}




\section{AÇÕES AFIRMATIVAS NA UNIVERSIDADE FEDERAL DE RONDÔNIA: EXPERIÊNCIAS BEM-SUCEDIDAS DE ACESSO AO ENSINO SUPERIOR}

Aparecida Luzia Alzira Zuin

Eliane Bastos

André Luiz Pestana Carneiro

\section{Introdução}

Esse artigo tem por objetivo analisar como a Universidade Federal de Rondônia (UNIR) vem aplicando a Lei no 12.711/2012 (Lei de Cotas), desde o processo seletivo de 2013 a 2017, para o ingresso de cotistas no curso de Direito, do Campus José Ribeiro Filho, em Porto Velho. O problema que orientou a pesquisa foi se as cotas, enquanto política pública de ação afirmativa para negros, são favoráveis ao atendimento da justiça social com equidade. O recorte evidenciado para o curso de Direito se deu em virtude de uma das pesquisadoras deste trabalho ser docente e os outros dois pesquisadores serem egressos dos cursos de Direito e do Mestrado Acadêmico em Educação (PPGE); além de ser o segundo curso mais concorrido da UNIR.

O aporte teórico epistemológico respaldou-se nas concepções de Paulo Freire; Anísio Teixeira; com os métodos educacionais e políticos em vistas à democracia, educação e inclusão social. A opção teórica em questão corroborou não somente à discussãoão sobre a Lei de Cotas, enquanto política pública de inclusão social, mas, também, para a defesa do direito à educação mais humanizada, de qualidade social e de respeito a todos os cidadãos e cidadãs brasileiros/as. A abordagem é qualitativa, com estudo de caso; acrescida das características exploratórias e descritivas, utilizando-se pesquisa bibliográfica e documental. A execução desta etapa compreendeu: o levantamento de dados e análise comparativa do material coletado no sítio da UNIR - aba Concursos e Vestibulares; no Sistema Integrado de Gestão Universitária (SINGU), no 
arquivo físico da Diretoria de Registro e Controle Acadêmico (DIRCA) e entrevista com servidores da Comissão Permanente de Processo Seletivo de Discente (CPPSD). Os resultados encontrados assinalaram que as cotas hoje, apesar de uma série de críticas, oposições e erros de aplicação, têm sido a possibilidade de ingresso no ensino superior público para os negros, principalmente, nos cursos de Medicina e Direito que são os mais concorridos nesta Instituição Federal de Ensino Superior, mas também, nas Licenciaturas, a política tem se demonstrado inclusiva.

\section{A exclusão dos negros no Ensino Superior e a Lei de Cotas}

Para compreendermos a relevância dos estudos desta pesquisa, dados atuais demonstram que pela primeira vez, no Brasil, em 2018, o número de negros no Ensino Superior público superou o número de brancos, de acordo com a pesquisa “Desigualdades Sociais por Cor ou Raça no Brasil”, com base na Pesquisa Nacional por Amostra de Domicílios Contínua - PNAD, realizada pelo Instituto Brasileiro de Geografia e Estatística (IBGE, 2019). Consta no relatório da pesquisa, de modo mais conclusivo que, “[...] com a trajetória de melhora nos indicadores de adequação, atraso e abandono escolar, estudantes pretos ou pardos passaram a compor maioria nas instituições de ensino superior da rede pública do País (50,3\%), em 2018” (IBGE, 2019, p. 9). Entretanto, assinala o Instituto (2019, p. 9), os negros seguiam, no mesmo ano, sub-representados, visto que constituíam 55,8\% da população, o que respalda a existência das medidas que ampliam e democratizam o acesso à rede pública de ensino superior.

O ensino superior foi por muitos séculos reservado à classe dominante, pois o ensino secundário, que era o único caminho de alcançar o ensino superior, não era expandido para as classes menos abastadas da sociedade (Teixeira, 1989, p. 42), o que incluía a população negra. Assim, o caráter múltiplo das ações afirmativas nos remete ao objetivo principal: atingir a igualdade racial no imaginário coletivo real, induzindo às transformações de ordem cultural, pedagógica e psicológica. Nessa perspectiva, o objetivo das ações afirmativas não é, essencialmente, coibir o racismo, mas promover a igualdade racial, 
criando diversidade e representatividade estatal e social, eliminado as barreiras raciais, artificiais e invisíveis (Santos, 2005).

A fim de respaldar a existência das medidas possibilitadoras da ampliação e democratização do ensino público superior no Brasil, a Lei nº12.711/2012 (Lei de Cotas) destina 50\% das vagas em Universidades e Institutos Federais para estudantes oriundos de escolas públicas, considerando critérios, tais como: origem escolar (escola pública), renda familiar e raça.

Para a compreensão sobre a Lei de Cotas e sua significação no contexto brasileiro é necessária uma breve retomada dos acontecimentos históricos de discriminação, exclusão, marginalização da população negra no Brasil. Se a colonização europeia deixou vestígios perceptíveis destes fatores históricos com relação à população indígena; o período da escravidão também deixou marcas profundas de exploração da população negra. Sabe-se que indígenas e negros, ainda hoje (2021), sofrem as consequências deste processo histórico, sendo privados de sua cultura e da condição de dignidade humana, em virtude da exacerbação do ideal capitalista, no qual, ainda parte da elite branca continua impondo sua condição de superioridade.

Segundo Oliveira (2004, p. 48), desde a era colonial, com a proibição dos negros - ainda que livres, de frequentarem a escola, não impediu que esta população buscasse a sua condição de titular de direitos. Em 1831, mesmo com a proibição do tráfico negreiro, aumentou o número de negros marginalizados, que, consequentemente, permaneceram sem qualquer direito à educação pública.

A história da escravidão legal oficial no Brasil cessou formalmente em 13 de maio de 1888, com a promulgação da Lei Áurea assinada pela princesa Isabel, filha do imperador D. Pedro II. O texto da lei era composto por apenas dois artigos: "Artigo $1^{\circ}$ - É declarada extinta a escravidão no Brasil. Artigo 2o - Revogam-se as disposições em contrário.” Na ocasião, existiam pouco mais de 700 mil escravos no país que deixaram a condição de servidão, mas não obtiveram o apoio oficial de assistência ou transição para a dita liberdade por parte do governo imperial, ficando sujeitos à miséria e à marginalização social. Não havia direitos trabalhistas para os negros, ainda que livres antes da abolição da escravidão. Esse grande contingente 
de pessoas se viu sem perspectivas de trabalho, porque a qualificada mãode-obra dos imigrantes europeus (brancos) já estava presente no Brasil, ampliando as dificuldades dos negros, inclusive ao acesso à educação.

Para Anísio Teixeira, a condição de marginalização de parte da população brasileira seguiu esse roteiro histórico, porque a escola da elite, no fim do período colonial, era para os filhos dos antigos proprietários rurais e da nascente classe comercial que abrangia a escola secundária de caráter "pseudo-humanístico" e a escola superior. Para a maioria do povo, que às vezes alcançava a escola, o que não incluía os negros livres, havia a escola primária, a escola de artes e ofícios e a escola normal, em dois sistemas independentes (Teixeira, 1989, 42).

Embora a educação no Brasil tenha obtido algum avanço, desde a Constituição de 1824 e a de 1988, a condição dos negros em relação à escolaridade não obteve grandes resultados, principalmente, em relação ao ensino superior. $\mathrm{Na}$ Constituição de 1824 , os textos constitucionais declaram a igualdade de todos perante a lei, todavia, nesta Constituição se excluiu da definição de cidadão, a população escravizada. Sem o reconhecimento da cidadania aos negros, não havia como assegurar a eles qualquer direito civil. Assim se seguiu por longo tempo, pois o Brasil foi o último país das Américas a abolir a escravidão, somente em 1888; após ter recebido, em três séculos, milhões de africanos escravizados.

Ao final do Império, intensificaram-se os debates sobre a necessidade da educação pública associada aos temas sociais que alteraram o panorama da sociedade brasileira, como a recém Abolição da Escravatura, o incentivo à imigração estrangeira, a modernização técnica da produção pela introdução de máquinas, a realidade republicana do País e a própria formação do trabalhador. Segundo Saviani (2004, p. 22): “[...] pensava-se na instituição da escola pública e na adoção do sistema agrícola para criar o gosto pelo trabalho ao homem livre e ao ex-escravo recém liberto".

Com a Constituição Republicana de 1891, foram introduzidos alguns direitos, como os direitos de participação ao voto do cidadão, mas, impôs a alfabetização como critério para o direito ao voto, em um contexto em que praticamente toda a população negra era analfabeta; ou seja, não se estabele- 
ceu nenhuma inovação em relação à Constituição anterior, deixando de lado questões importantes como a gratuidade e a obrigatoriedade da educação pública a todos, mantendo os estados e municípios como únicos responsáveis pela educação primária e essencial para a população negra livre recém-liberta.

A partir de 1930, há uma nova mudança em relação à educação pública. A década de 30 é reconhecida como o marco referencial da modernidade na história do Brasil. Modernidade entendida como o processo de industrialização e urbanização, contemplada por inúmeros estudos que destacam esse período pelas mudanças que inauguraram e os movimentos políticos que as protagonizaram, a Revolução de outubro de 1930 e o Estado Novo, oficialmente instalado em 1937.

A Constituição de 1934, por sua vez, inovou no aspecto referente à igualdade, prescrevendo no art. 113 a igualdade entre os cidadãos, independentemente de nascimento, sexo, raça, profissões próprias ou dos pais, classe social, riqueza, crenças religiosas ou ideias políticas. $\mathrm{O}$ termo raça foi empregado no sentido cor da pele e etnia, precisamente no aspecto: negro, branco, indígena. Além dos termos novos, foi a primeira Constituição a fixar como competência privativa da União traçar as diretrizes da educação nacional (art. 5o), como forma de organizar a educação em âmbito nacional com vistas à consolidação do sistema de educação pública. Por outro lado, foi a que menos durou em toda a história legislativa brasileira: - apenas três anos; tendo vigorado oficialmente apenas um ano, já que foi suspensa pela Lei de Segurança Nacional (Lei no . 6.620/1978), em vigor na época.

Não obstante à fixação da competência para a União traçar as diretrizes da educação nacional, não houve mudança significativa para a educação básica, apenas para o ensino superior no que se refere à autonomia universitária.

Em virtude da expansão do regime de estado socialista no mundo, após a Primeira Guerra Mundial e, em razão dos ideais sociais que envolveram a promulgação da Constituição de 1934, instalou-se o Estado Novo com o Presidente Getúlio Vagas, legitimado pela Constituição de 1937; e trouxe à tona a concentração da maior parte dos poderes da República ao Poder Executivo (Presidente da República). Na área da educação, permaneceu a competência 
da União para legislar sobre as diretrizes e bases da educação nacional, mas delegou à família a responsabilidade primária para a educação dos filhos e ao Estado a colaboração secundária (art. 125).

A Constituição de 1946 manteve o padrão do texto, estabelecendo a igualdade de todos perante a lei formalmente, mas que na realidade, observa-se a diferença, haja vista a competência privativa da União para fixar as diretrizes e bases da educação nacional. Aqui, novamente, não se fez qualquer menção aos negros, indígenas, ou mesmo à população de baixa renda, como constou no texto a Constituição de 1934.

Durante os anos de 1964 e 1970, com a ditadura militar, foram suprimidas muitas formas de liberdade intelectual e atividade política, dificultando a organização dos movimentos sociais e, entre eles, do Movimento Negro. Todavia, não foi impedimento, porque neste período surgiram várias formas de resistência cultural negra, particularmente nos grandes centros urbanos.

A Constituição Federal de 1988 (CF/88), conhecida como a Constituição Cidadã, considerando o contexto mundial de priorização da educação e pesquisa científica, foi a que mais se aproximou das questões referentes às políticas públicas, formas de universalização e inclusão social como maneira de diminuir as disparidades regionais existentes no Brasil, consagrando as conquistas e a mobilização da comunidade educacional, como dos diversos movimentos sociais organizados. Mas, por serem normas programáticas, dependem efetivamente da atuação dos governos municipal, estadual e federal.

Para Saviani (2004, p. 46), entre as principais conquistas deste período histórico-constitucional estão o direito à educação a partir do nascimento, a gratuidade do ensino público em todos os níveis (básico, fundamental, médio e superior). $\mathrm{Na}$ área do ensino superior, a Constituição da República Federativa do Brasil de 1988 foi ainda mais ousada que as anteriores, e deu às instituições públicas de ensino superior plena autonomia didático-científica-administrativa e de gestão financeira e patrimonial, obedecendo ao princípio de indissociabilidade entre ensino, pesquisa e extensão. Dessa ampla autonomia outorgada às universidades públicas surgiu a ideia, pelas próprias universidades, de disponibilizar parte das vagas aos negros, tendo em vista a estagnação dos números referentes à escolaridade entre negros 
em relação à população branca e eliminar os efeitos persistentes da discriminação do passado, que tende a se perpetuar.

No ano de 1995, por ocasião da comemoração dos 300 anos da morte de Zumbi dos Palmares, realizou-se a marcha em direção à Brasília, em 20 de novembro, denominada "Marcha Zumbi dos Palmares, Contra o Racismo pela Cidadania e a Vida" e pela «Libertação dos Negros”. Na ocasião, o Movimento Negro entregou ao Presidente da República na época, Fernando Henrique Cardoso, um manifesto com as reivindicações, exigindo a elaboração de políticas públicas e ações concretas do Estado para oferecer condições à promoção da igualdade de oportunidades e a eliminação de qualquer forma de discriminação racial na sociedade.

Nesse manifesto: "Marcha Zumbi dos Palmaras Contra o Racismo pela Cidadania e a Vida”, constou as seguintes propostas para melhoria na educação brasileira para a população negra: a) desenvolvimento de ações afirmativas para o acesso dos negros aos cursos profissionalizantes, às universidades e às áreas de tecnologias de ponta; b) recuperação, fortalecimento e ampliação das escolas públicas, gratuitas e de qualidade; c) implementação da "Convenção sobre Eliminação da Discriminação Racial no Ensino"; d) monitoramento dos livros didáticos, manuais escolares e programas educativos controlados pela União; e) desenvolvimento de programas permanentes de treinamento de professores e educadores que os habilitem a tratar adequadamente a diversidade racial, identificar as práticas discriminatórias presentes na escola e o impacto da evasão e repetência das crianças negras; f) desenvolvimento de programas educacionais de emergência para a eliminação do analfabetismo; g) concessão de bolsas remuneradas para adolescentes negros de baixa renda para o acesso e conclusão do ensino fundamental e médio.

\section{Lei de Cotas na Universidade Federal de Rondônia e o impacto para o aces- so da população Negra ao Ensino Superior - Curso de Direito}

As ações afirmativas podem ser definidas como políticas que beneficiam ativamente grupos, não relativamente minoritários, socialmente desfavorecidos 
na destinação de diretrizes específicas, a fim de fomentar a inclusão dos mesmos em áreas como: mercado de trabalho, vagas nas universidades e contratos públicos e, objetivam concretizar a igualdade material. Mais, a ideia de ações afirmativas abrange políticas que visam combater o racismo existente na sociedade e corrigir efeitos de racismos históricos, como no caso do Brasil, idealizando a igualdade material (não apenas a formal, do texto da Lei) de acesso aos bens fundamentais em uma democracia sólida, como é o caso do Ensino Superior. São políticas/ações não simplesmente voltadas para a intervenção posterior, mas com caráter político e múltiplo de ação, tanto sobre os efeitos da desigualdade histórica quanto sobre o racismo atual, pode-se afirmar que atua ainda como uma prevenção a um futuro aumento do racismo.

Isso ocorre quando a democracia é o instrumento de exercício de diversos valores conquistados pelo homem, pautados na dignidade da pessoa humana, e que, no passar do tempo, se transformaram em direitos fundamentais (Silva, 2007, p. 126). Esses valores são a vontade soberana do povo como a legítima vontade e ação a ser aplicada pelo governante, não havendo espaço aos interesses pessoais ou de grupos determinados, mas sim, com interesses difusos, impessoais. Com isso, ingressar, frequentar e concluir um nível de ensino, por exemplo, se transforma em uma vantagem ou até mesmo em um ato político e de ascensão social que esse ensino possa oferecer, o que acaba por incentivar a procura por esse direito - o ingresso na escola, principalmente, ingressar, frequentar e concluir o ensino superior. Anísio Teixeira, desde 1969, apontava a democracia vincula ao ato da educação.

[...] a democracia não pode existir sem educação para todos e cada um, pois importa em transformar, não alguns homens, mas todos os homens para - contra tendências hereditárias, sociais, se não biológicas - rematar, por evolução consciente, a obra que as sucessivas civilizações, desde o começo dos séculos, vêm realizando pela injustiça e consequente violência. Todas as outras formas de sociedade precisam de alguma educação, mas só a democracia precisa de educação para todos e na maior quantidade possível (Teixeira, 1989, p. 220). 
Para Anísio Teixeira (1989, p. 17), a democracia em seus direitos fundamentais nos documentos legais, pregava a liberdade de expressão, de reunião e organização, que, ao lado da liberdade de ir e vir, estava sempre subordinada a uma condição fundamental: o direito à educação.

Nesse sentido, a defesa da Lei das Cotas vai ao encontro dessa concessão, porque o que se prevê é que haja a diminuição das disparidades entre as classes sociais e/ou étnicas, em vista à igualdade como direito fundamental e à inclusão no ensino superior. Por isso, a inclusão social, que está associada à dignidade da pessoa humana, tende a proporcionar a participação dos mais pobres e/ou negros(as) (o que inclui pretos e pardos) na comunidade acadêmica, elevando, portanto, o grau de escolaridade desses grupos; e, a médio prazo, a diminuição do abismo socioeconômico entre as diferentes classes sociais que compõem a sociedade brasileira, contribuindo, também, para eliminar o estigma social da origem da população negra” (Brandão, 2005, p. 88).

Nesse sentido, a Lei de Cotas, com base em Paulo Freire (1988), é uma ação inclusiva, consequentemente, um processo político; porque o acesso ao conhecimento aumenta as possibilidades de o indivíduo alcançar melhores condições de vida. A educação e o conhecimento são processos de busca e transformação. Ainda segundo Freire, essa educação é um ato de problematização dos homens sobre o mundo, "[...] é práxis que implica a ação e a reflexão dos homens sobre o mundo para transformá-lo" (Freire, 1988, p. 67). Educar para Transformar é lema da pedagogia de Freire.

Em vistas à ação política de inclusão no ensino superior,o Fórum Nacional de Pró-Reitores de Assuntos Comunitários e Estudantis (FONAPRACE), com a finalidade de traçar o perfil socioeconômico e cultural dos mais de um milhão de estudantes da graduação pública federal, realiza periodicamente pesquisa a nível nacional. $\mathrm{Na}$ pesquisa realizada pelo fórum em 2010, com a participação de vários estudantes das 56 instituições federais de ensino superior, constatou-se que $43,74 \%$ dos alunos das universidades federais pertenciam às classes $\mathrm{C}, \mathrm{D}$ e $\mathrm{E}$; e que o percentual de estudantes de raça/ cor/etnia preta aumentou de 5,9\% em 2004 (período da pesquisa anterior) para 8,7\%, em 2010 (FONAPRACE, 2010). A última pesquisa realizada em 
2014 e publicada em 2016 revelou que a universidade caminha na direção de espelhar a composição social atual do Brasil. A universidade em sua maioria é feminina e cada vez mais popular e negra. O diagnóstico extraído resulta de um processo de democratização do acesso, com programas, tais como o Enem/ Sisu e a Lei 12.711/2012 (Lei de Cotas) que permitiram mais mobilidade territorial e justiça social e étnico-racial (FONAPRACE, 2016, p. 16).

Verifica-se que no período de 1996 e 2014, houve uma redução da população branca na sociedade brasileira, antes em torno de 55\% e chegando ao final do período com 45\%, e um crescimento significativo da população preta e parda, que de $44 \%$ passou para mais de 53\%. Segundo a pesquisa, é uma mudança significativa para um perfil populacional e que parece estar mais relacionada ao processo de autodeclaração, com a mudança daqueles que se autodeclaravam brancos apenas como um resultado de um racismo latente na sociedade (FONAPRACE, 2016, p. 4).

Seguindo a política de ação afirmativa - Lei de Cotas, a Universidade Federal de Rondônia passou a disponibilizar vagas para cotistas nos processos seletivos para ingressos de negros no ensino superior.

Para conhecer um pouco, a Fundação Universidade Federal de Rondônia foi criada pela Lei Federal no 7.011 de 08 de julho de 1982 (Brasil, 1982). A Unir é a única Universidade pública do estado de Rondônia, atualmente com oito campi localizados nos municípios de Ariquemes, Cacoal, Guajará-Mirim, Ji-Paraná, Porto Velho (sede), Presidente Médici, Rolim de Moura e Vilhena. Por possuir em sua estrutura esses oito campi que levam o ensino superior gratuito às mais diversas regiões do estado, é considerada multicampi. Com os dados abaixo, é possível observar o importante papel da Instituição no contexto rondoniense e amazônico.

A tabela a seguir apresenta o quantitativo de vagas disponibilizadas pela Fundação Universidade Federal de Rondônia (UNIR) no curso de Direito, do Campus Porto Velho, destinadas aos cotistas de forma geral, e a quantidade de vagas destinadas aos cotistas negros (pretos e pardos): 
Tabela 1 - Vagas e quantitativo de cotistas negros: Direito (Nucsa) Porto Velho.

\begin{tabular}{ccccc}
\hline \multirow{2}{*}{ ANO } & SEMESTRE & $\begin{array}{c}\text { VAGAS } \\
\text { TOTAIS }\end{array}$ & $\begin{array}{c}\text { VAGAS } \\
\text { COTAS } \\
\text { GERAL }\end{array}$ & $\begin{array}{c}\text { COTAS NEGROS } \\
\text { (PRETOS/PARDOS) }\end{array}$ \\
\hline \multirow{2}{*}{2013} & $1^{\circ}$ & & 7 & S/INF \\
& $2^{\circ}$ & & 7 & S/INF \\
2014 & $1^{\circ}$ & & 14 & S/INF \\
& $2^{\circ}$ & & 14 & S/INF \\
2015 & $1^{\circ}$ & 50 & 25 & 16 \\
& $2^{\circ}$ & & 25 & 16 \\
2016 & $1^{\circ}$ & & 25 & 16 \\
& $2^{\circ}$ & & 25 & 16 \\
2017 & $1^{\circ}$ & 25 & 16 \\
\hline
\end{tabular}

Fonte: Singu e Dirca (Extração 2017-2).

Na publicação do resultado final do processo seletivo de 2013 (UNIR, 2013), não constou o nome dos candidatos aprovados, apenas o Cadastro de Pessoa Física (CPF), número de inscrição no Exame Nacional de Ensino Médico (Enem) e a data de nascimento, sem a identificação dos candidatos aprovados nas cotas que foram disponibilizadas ( 7 vagas) no curso de direito para o ingresso no primeiro e no segundo semestres. $O$ edital de matrícula do primeiro semestre também não constou essas informações e acabou por inviabilizar a análise de dados nesse processo seletivo. No edital de matrícula ao ingresso nos cursos do segundo semestre, constou o nome dos candidatos aprovados como cotistas, porém, sem individualização da cota (preto, pardo, indígena).

A falta de informações que individualize os cotistas prejudica sensivelmente o acompanhamento da Lei de Cotas, haja vista que após o prazo de dez anos, a partir de 2013, deverá ser promovida a revisão dessa medida especial pelas próprias universidades, nos termos do art. $7^{\circ}$ da Lei de Cotas. A revisão na Unir deverá ser feita justamente com as informações disponíveis no Sistema de Gestão Universitária (Singu), além de outras relacionadas ao desempenho universitário, participação em projetos de pesquisa, extensão, como às informações inerentes à assistência estudantil. 
Nos processos seletivos, dos anos de 2013 e 2014, foram implementadas as obrigações estabelecidas na Lei de Cotas. Mas, em razão do novo procedimento não possuir manuais de padronização por parte do Ministério da Educação (MEC), houve algumas falhas na execução que somente foram corrigidas por recomendação do Ministério Público Federal em Rondônia (MPF-RO). No processo seletivo de 2013 e 2014, todos os cotistas (pretos, pardos, indígenas), concorriam entre si, sem que houvesse qualquer individualização das vagas. Essa nova configuração compreende, particularmente, o aumento de grupos étnicos minoritários como negros, pardos e índios, conforme quadro geral da Unir a partir de 2013:

Quadro 1 - Ingressantes por cotas no ano de 2013. Todos os Campi da UNIR.

\begin{tabular}{|c|c|c|c|}
\hline \multirow{8}{*}{$\begin{array}{l}\text { TOTAL DE IN- } \\
\text { GRESSANTES } \\
\text { POR COTAS: } 313\end{array}$} & \multirow{4}{*}{$\begin{array}{l}\text { COM RENDA <=1,5 } \\
\text { SALÁRIOS: } 187\end{array}$} & \multirow{3}{*}{$\begin{array}{l}\text { COM ETNIA DE- } \\
\text { CLARADA: } 140\end{array}$} & PARDO: 115 \\
\hline & & & PRETO: 24 \\
\hline & & & INDÍGENA: 1 \\
\hline & & \multicolumn{2}{|c|}{ SEM ETNIA DECLARADA: 47} \\
\hline & \multirow{4}{*}{$\begin{array}{l}\text { COM RENDA >1,5 } \\
\text { SALÁRIOS: } 126\end{array}$} & \multirow{3}{*}{$\begin{array}{l}\text { COM ETNIA DE- } \\
\text { CLARADA: } 89\end{array}$} & PARDO: 77 \\
\hline & & & PRETO: 12 \\
\hline & & & INDÍGENA: 0 \\
\hline & & \multicolumn{2}{|c|}{ SEM ETNIA DECLARADA: 37} \\
\hline
\end{tabular}

Fonte: Dirca (Extração 2018-1).

Diante dos conflitos de informações dos processos seletivos de $2013 \mathrm{e}$ 2014 e em razão da Lei de Cotas ainda não ter sido implementada integralmente, optou-se pela análise de dados no curso de Direito em Porto Velho, no período entre 2015 a 2017, referentes ao primeiro e ao segundo semestre. Com a elaboração da Resolução no. 416/Consea/2015 que detalhou cada uma das cotas, em cumprimento à recomendação expedida pelo MPF-RO, facilitou a análise e a publicação dos dados para a sociedade, que passou a entender melhor e a visualizar a quantidade exata de vagas para cada curso na condição das cotas. No processo seletivo de 2014 houve um aumento 
no número das vagas de cotas, que dobraram de 7 (sete) para 14 (catorze) vagas. $\mathrm{O}$ resultado final do processo seletivo foi publicado com o nome dos candidatos, número de inscrição no Enem. Constou os aprovados na condição de cotista. Entretanto, novamente não houve a individualização de acordo com cada tipo de cota (preto, pardo, indígena).

Quadro 2 - Perfil cotistas negros: Direito (Nucsa) Porto Velho 2015.

\begin{tabular}{|c|c|c|c|c|c|c|}
\hline ANO & SEMESTRE & $\begin{array}{c}\text { COTAS } \\
\text { PRETOS }\end{array}$ & $\begin{array}{c}\text { COTAS } \\
\text { PARDOS }\end{array}$ & $\begin{array}{c}\text { GENERO } \\
\text { MAIORIA }\end{array}$ & $\begin{array}{c}\text { FAIXA ETÁ- } \\
\text { RIA } \\
\text { (MÉDIA) }\end{array}$ & $\begin{array}{c}\text { NATURALI- } \\
\text { DADE } \\
\text { (MAIORIA) }\end{array}$ \\
\hline 2015 & $1^{\circ}$ & 02 & 14 & $\begin{array}{c}\text { MASCULI- } \\
\text { NO 60\% }\end{array}$ & 25,94 ANOS & $\begin{array}{c}\text { PORTO VE- } \\
\text { LHO 60\% }\end{array}$ \\
\cline { 2 - 7 } & $2^{\circ}$ & 02 & 14 & $\begin{array}{c}\text { MASCULI- } \\
\text { NO 60\% }\end{array}$ & 33,76 ANOS & $\begin{array}{c}\text { PORTO VE- } \\
\text { LHO 60\% }\end{array}$ \\
\hline
\end{tabular}

Fonte: Singu (Extração 2017-2).

$\mathrm{Na}$ turma do curso de Direito, o ingresso de cotistas no primeiro semestre de 2015, apresentou a maioria dos alunos do gênero masculino: 10 homens e 06 mulheres; com a média de faixa-etária em torno de 25 anos. Nesta turma, a Escola Estadual de Educação Básica (EEEB) João Bento da Costa, localizada na Zona Sul Urbana de Porto Velho, foi a que mais logrou êxito em inserir 7 (sete) alunos na turma. No ingresso no segundo semestre de 2015 apresentou uma elevada faixa etária para os cotistas negros se comparada aos anos posteriores. A maioria dos alunos são nascidos em Porto Velho, entanto, aparecem outros com naturalidade em: Recife, Ilhéus, Ji-Paraná, Limoeiro, Pedreiras, Pimenta Bueno (que é Município de Rondônia, mas não possui Campus da Unir), sendo que esses alunos também concluíram o ensino médio em escolas públicas não localizadas na Capital. Grande parte também havia concluído o ensino médio há mais de 3 (três) anos.

$\mathrm{Na}$ sequência, em 2016, contou com 17 alunos cotistas matriculados. O número é superior ao previsto (16), porque houve um cancelamento de matrícula, que é o pedido formal de desistência do curso, que normalmente é feito quando o aluno obteve a aprovação em outro curso de sua preferência 
ou não mais deseja fazer parte do quadro de alunos da Unir, o que ocasionou o chamamento de mais um cotista. A Escola pública, de Ensino Básico, João Bento da Costa também ganha, novamente, destaque com a provação de 05 alunos. A procedência dos alunos, a fim de saber se vieram de outros estados, não se encontra disponível no sistema Singu, haja vista que não é uma informação preponderante para a matrícula. Todavia, a informação de procedência é relevante para a análise e concessão de benefícios de assistência estudantil pelo Programa Pnaes.

Quadro 3 - Perfil cotistas negros: Direito (Nucsa) Porto Velho 2016.

\begin{tabular}{|c|c|c|c|c|c|c|}
\hline ANO & SEMESTRE & $\begin{array}{c}\text { COTAS } \\
\text { PRE- } \\
\text { TOS }\end{array}$ & $\begin{array}{c}\text { COTAS } \\
\text { PARDOS }\end{array}$ & $\begin{array}{c}\text { GENERO } \\
\text { MAIORIA }\end{array}$ & $\begin{array}{c}\text { FAIXA } \\
\text { ETÁRIA } \\
\text { (MÉDIA) }\end{array}$ & $\begin{array}{c}\text { NATURALI- } \\
\text { DADE } \\
\text { (MAIORIA) }\end{array}$ \\
\hline \multirow{2}{*}{2016} & $1^{\circ}$ & 02 & 14 & $\begin{array}{c}\text { MASCULI- } \\
\text { NO 60\% }\end{array}$ & $\begin{array}{c}25,59 \\
\text { ANOS }\end{array}$ & $\begin{array}{c}\text { PORTO VE- } \\
\text { LHO 60\% }\end{array}$ \\
\cline { 2 - 7 } & $2^{\circ}$ & 02 & 14 & $\begin{array}{c}\text { MASCULI- } \\
\text { NO 55\% }\end{array}$ & $\begin{array}{c}28,63 \\
\text { ANOS }\end{array}$ & $\begin{array}{c}\text { PORTO VE- } \\
\text { LHO 50\% }\end{array}$ \\
\hline
\end{tabular}

Fonte: Singu (Extração 2017-2).

Os alunos que ingressaram no curso no segundo semestre de 2016 são na maioria oriundos de outra cidade que não Porto Velho, de modo que ficou no percentual de $50 \%$. O número de mulheres também aumentou no percentual de 5\%, considerando o padrão de 60\% de homens no processo seletivo de 2015 e no primeiro semestre de 2016. Apesar de que, houve um número maior de alunos nascidos em outra cidade, a maior parte deles concluiu o ensino médio nas escolas públicas de Porto Velho, 60\%.

Quadro 4 - Perfil cotistas negros: Direito (Nucsa) Porto Velho 2017.

\begin{tabular}{|c|c|c|c|c|c|c|}
\hline ANO & $\begin{array}{c}\text { SEMES- } \\
\text { TRE }\end{array}$ & $\begin{array}{c}\text { COTAS } \\
\text { PRE- } \\
\text { TOS }\end{array}$ & $\begin{array}{c}\text { COTAS } \\
\text { PAR- } \\
\text { DOS }\end{array}$ & $\begin{array}{c}\text { GÊNERO } \\
\text { MAIORIA }\end{array}$ & $\begin{array}{c}\text { FAIXA ETÁ- } \\
\text { RIA } \\
\text { (MÉDIA) }\end{array}$ & $\begin{array}{c}\text { NATURALI- } \\
\text { DADE } \\
\text { (MAIORIA) }\end{array}$ \\
\hline & $1^{\circ}$ & 02 & 14 & $\begin{array}{c}\text { MASCULI- } \\
\text { NO 70\% }\end{array}$ & 20,62 ANOS & $\begin{array}{c}\text { PORTO VE- } \\
\text { LHO 75\% }\end{array}$ \\
\cline { 2 - 7 } & $2^{\circ}$ & 02 & 14 & $\begin{array}{c}\text { MASCULI- } \\
\text { NO 55\% }\end{array}$ & 26,88 ANOS & $\begin{array}{c}\text { PORTO VE- } \\
\text { LHO 55\% }\end{array}$ \\
\hline
\end{tabular}

Fonte: Singu (Extração 2017-2). 
A turma de Direito, com ingresso no primeiro semestre de 2017, apresentou a menor faixa etária para os cotistas negros do período de amostra da pesquisa, - 20,62 anos, sendo que o gênero masculino é de 70\%, com apenas cinco mulheres entre as cotistas negras. Ademais, $75 \%$ dos cotistas são oriundos de Porto Velho, e também, 75\% dos cotistas negros da turma concluíram o ensino médio em escola pública. Os alunos cotistas que ingressaram no segundo semestre são em sua maioria homens, 55\%; com média de idade de 26 anos, a maior parte nascida na cidade de Porto Velho.

A implementação dessa política de democratização do ensino superior, trouxe consigo não somente a possibilidade de entrada na Universidade Federal de uma parcela significativa de alunos socioeconomicamente desprestigiados, como também uma população mais diversificada para o interior dessas instituições. No contexto de Rondônia e da Amazônia Ocidental, esta tendência intercultural em vigência nas universidades brasileiras, através da garantia da presença de uma parcela maior de alunos negros, indígenas e oriundos de escola pública, significa a tentativa de superar toda uma trajetória de exclusão de um contingente de pessoas que até bem pouco tempo não tinha, ou era imensurável, acesso ao ensino superior público e gratuito. $\mathrm{Na}$ Unir, verifica-se que o número de ingressantes negros nos primeiros anos de aplicação da Lei de Cotas foi de 228 (duzentos e vinte e oito) alunos, sendo que a maioria é considerada de baixa renda, ou em situação de vulnerabilidade. Estas ações em conjunto às atividades de ensino, pesquisa e extensão, almejam uma trajetória acadêmica de qualidade a esses estudantes, principalmente aos cotistas negros. Conforme conceitua Santos (2009, p. 76), "[...] o espaço acadêmico é um local de posições sociais, no qual é produzido, consumido e classificado, neste espaço específico o conhecimento”. E como tal, em seu interior, os indivíduos envolvidos passam a lutar pelo controle da produção e, sobretudo, pelo direito de legitimamente classificarem e hierarquizarem os bens produzidos, como o ocorrido com os cotistas negros ao ingressarem no ensino superior, no curso de Direito da Unir. 


\section{Conclusão}

As políticas de ações afirmativas aplicadas nas instituições públicas de ensino superior, direcionadas ao acesso das populações negras, povos indígenas e estudantes de baixa renda, e de escolas públicas, têm como fundamento a reparação do passado histórico de exclusão dessas populações, os indicadores sociais atuais e a busca por justiça social. No caso dos negros, deve-se à luta pelo direito à educação remontada a uma série de movimentos travados ao longo dos anos. Submetidos à escravidão por mais de trezentos anos, só conseguiram a liberdade depois de muitos enfrentamentos. Vivendo, a maioria, nas periferias das cidades, sem acesso à moradia, saúde ou educação, a população negra passou por muitos anos de segregação e impedimento ao ingresso no ensino superior. Dados apontam que nos dias atuais essa população (os negros) têm os piores indicadores sociais como: renda, escolaridade, acesso a bens e serviços, e sofrem com os maiores índices de violência e morte.

$\mathrm{Na}$ tentativa de amenizar os problemas decorrentes do ingresso de negros nas instituições públicas de ensino superior, a implementação de políticas de ações afirmativas na Universidade Federal de Rondônia, as cotas e a reserva de vagas no processo seletivo discente, resultou em uma política com e para a Justiça social na UNIR. No que tange ao objetivo específico, acerca de detectar os alunos cotistas matriculados no curso de Direito, constatou-se que devido às cotas (Lei no 12.711/2012), o perfil dos alunos que ingressam neste curso foi alterado consideravelmente com a aplicação das cotas. Prosseguindo, nas análises, demonstrou que a Universidade Federal de Rondônia desde 2013 tem procurado se adequar e promover as medidas necessárias para a melhor aplicação da Lei das Cotas. Por outro lado, deve-se atentar à permanência. A permanência de estudantes com dificuldades socioeconômicas nas universidades públicas tem se tornado um grande desafio para a política das cotas, cujo objetivo principal é a reparação/atenuação das desigualdades existentes e a democratização do ingresso no ensino superior, com vistas à contribuição para o desenvolvimento e a diminuição das desigualdades regionais existentes no Brasil. Nessa perspectiva, para alguns segmentos historicamente marginalizados em relação à educação superior como a população negra, essa 
conquista consiste em esforço excepcional, principalmente, impulsionado pelo Movimento Negro ao longo das últimas décadas.

Nesse contexto, as universidades públicas são peças essenciais envolvidas na execução e acompanhamento efetivo do Programa Nacional de Assistência Estudantil(Pnaes), que por meio de dispositivos legais são dotadas de autonomia acadêmica para criar programas/projetos como estratégias de inclusão desses alunos, que podem ser, inclusive, ampliados, independentemente de legislação federal. Conclui-se que não só o ingresso é importante, mas reconhecer a importância da assistência estudantil para a permanência dos cotistas na universidade, e o efetivo acompanhamento da política se faz necessário.

A Universidade Federal de Rondônia (Unir) não possui, até o momento, a unidade organizacional ou setor em sua estrutura, responsável pelo acompanhamento dessas ações afirmativas voltadas ao ingresso da população negra, indígena, pessoa com deficiência, estudantes oriundos de escolas públicas em situação de vulnerabilidade social. Todavia, apesar das dificuldades e alguns desafios inerentes à aplicação da Lei de Cotas, a Unir vem cumprindo sua função no lugar onde se localiza, isto é, no estado de Rondônia, na região Norte, Amazônia Ocidental brasileira, onde de acordo com o Instituto Brasileiro de Geografia e Estatística (IBGE, 2005), a população negra era de 64,2\%; conforme dados do Universo - Indicadores sociais municipais, dados sobre a cor ou raça -preta/parda , o valor médio do rendimento mensal total nominal (IBGE, 2010, Unidade: B/C ) é de 1,1 salário mínimo.

\section{Referências}

BRANDÃO, Carlos da Fonseca. As Cotas na Universidade Pública Brasileira: Será esse o caminho? Campinas: Autores Associados, 2005.

\section{BRASIL. Constituição da República dos Estados Unidos do Brasil de 1891.}

Rio de Janeiro, 1891. Disponível em: http://www.planalto.gov.br/ccivil_03/ Constituicao/Constituicao91.htm. Acesso em: 31 de out. 2018.

\section{BRASIL. Constituição da República dos Estados Unidos do Brasil de 1934.}

Rio de Janeiro, 1934. Disponível em: http://www.planalto.gov.br/ccivil_03/ Constituicao/Constituicao34.htm. Acesso em: 31 de out. 2018. 
BRASIL. Constituição da República dos Estados Unidos do Brasil de 1937. Rio de Janeiro, 1937. Disponível em: http://www.planalto.gov.br/ccivil_03/ Constituicao/Constituicao37.htm. Acesso em: 31 de out. 2018.

BRASIL. Constituição da República Federativa do Brasil de 1967. Brasília, 1967. Disponível em: http://www.planalto.gov.br/ccivil_03/Constituicao/ Constituicao67.htm. Acesso em: 31 de out. 2018.

BRASIL. Constituição da República Federativa do Brasil de 1988. Brasília, 1988. Disponível em: http://www.planalto.gov.br/ccivil_03/constituicao/ constituicao.htm. Acesso em: 25 de mai. 2018.

BRASIL. Presidência da República - Casa Civil - Subchefia para Assuntos Jurídicos. Lei no 12.711 de 29 de agosto de 2012. Cotas. Disponível em: http:// www.planalto.gov.br/ccivil_03/_ato2011-2014/2012/lei/112711.htm. Acesso em: 13 de jul. 2018.

FONAPRACE. Fórum Nacional de Pró-Reitores de Assuntos Comunitários e Estudantis. IV Pesquisa do perfil socioeconômico e cultural dos estudantes de graduação das instituições federais de ensino superior brasileiras 2014. Andifes. Minas Gerais, Uberlândia, 2016.

FREIRE, Paulo. Pedagogia do Oprimido. Rio de Janeiro: Paz e Terra, 1988.

IBGE. Pesquisa Nacional por Amostra de Domicílios. PNAD 2005. População, por Raça/Cor Unidades da Federação 2005. Disponível em: http://produtos. seade.gov.br/produtos/idr/download/populacao.pdf. Acesso em: 12 de abr. 2019.

IBGE. Universo - Indicadores sociais municipais / Razão / Cor ou raça / Preta/Parda / Valor médio do rendimento mensal total nominal. Unidade: B/C. Disponível em: https://cidades.ibge.gov.br/brasil/ro/porto-velho/pesquisa/23/25124?tipo $=$ ranking\&indicador $=29535 \&$ localidade $2=0$. Acesso em: 15 de fev. 2019.

IPEA. Instituto de Pesquisa Econômica Aplicada. Estudo mostra desigualdades de gênero e raça em 20 anos. Disponível em: http://www.ipea.gov.br/ 
portal/index.php?option=com_content\&view=article\&id=29526 Acesso em: 28 de out. 2018.

OLIVEIRA, Graziela de. O negro na História da Educação Superior no Brasil. Universidade e Sociedade, v. 34, ano XIV, outubro de 2004.

SANTOS, Dyane Brito Reis. Para além das cotas: a permanência de estudantes negros no ensino superior como política de ação afirmativa. Salvador: UFBA, 2009. Tese de Doutorado. 311 f. Doutorado em Educação, Universidade Federal da Bahia, 2009.

SANTOS, João Paulo de Faria. Ações afirmativas e igualdade racial: a contribuição do direito na construção de um Brasil diverso. São Paulo. Edições Loyola, 2005.

SAVIANI, Demeval et al. O legado educacional do século XIX. 2. ed. rev. e ampl. Campinas: Autores Associados, 2004.

TEIXEIRA, Anísio Spínola. Ensino Superior no Brasil: análise e interpretação de sua evolução até 1969. Rio de Janeiro: Editora da Fundação Getúlio Vargas, 1989.

UNIR. Departamento de Ciências Jurídicas. Disponível em: http://www.dcj. unir.br/pages/npj.php. Acesso em: 12 de ago. 2018.

UNIR. Diretoria de Registro e Controle Acadêmico. Disponível em: http:// www.dirca.unir.br/. Acesso em: 09 de jun. 2018.

UNIR. Processo Seletivo. Disponível em: http://www.processoseletivo.unir. br. Acesso em: 23 de maio 2018.

UNIR. Vestibular. Disponível em: http://www.vestibular.unir.br/. Acesso em: 15 de jul. 2018. 


\section{EDUCAÇÃO ESCOLAR INDÍGENA: REFLEXÕES SO- BRE A FORMAÇÃO DE PROFESSORES ÍNDIOS}

Célio José Borges

Edilene Ferreira Gama

\section{Introdução}

Neste estudo objetiva-se pontuar as especificidades mais centrais da educação escolar indígena e quais competências são necessárias ao professor para o desempenho de suas atribuições na comunidade.

Durante centenas de anos as populações indígenas lutaram por sua sobrevivência, tanto em situações de extermínio, quanto em tentativas de aculturamento através de programas escolares integracionistas/assimilacionistas, tais programas tiveram sua maior predominância na época do Brasil colônia, com a chegada dos jesuítas, na perspectiva da educação tradicional. Após anos de resistências e luta política, conquistaram reconhecimento na Constituição Federal de 1988, onde obtiveram o direito à educação em sua língua materna, respeito a diversidade e a interculturalidade, além da posse de suas terras, tudo isso encontra-se elencando em nossa Carta Magna de 1988, no Art. 210 e na seção III, capítulo VIII, artigos 231 e 232.

Nesse contexto, a lei garante um novo modelo de educação indígena, intercultural e bilíngue cuja composição tem como objetivo a preservação das culturas nativas e a apropriação pelos indígenas de conteúdos da cultura nacional que sejam ferramentas para que ele possa usufruir também dos avanços da sociedade circundante.

O esteio desse novo modelo educacional é o professor indígena, a quem cabe proporcionar essas habilidades ao seu povo. Por orientação do próprio MEC, através da Secretaria de Educação Continuada, Alfabetização, Diversidade e Inclusão (SECADI) essa formação pode realizar-se "em serviço" numa associação entre teoria e prática. $\mathrm{O}$ que nos leva a pergunta que orienta essa 
pesquisa: Como deve ser estruturado um curso de formação em magistério indígena para que atenda as particularidades e diversidade da educação étnica?

Esta é uma pesquisa bibliográfica realizada principalmente em teses e dissertações do Banco Digital de Teses e Dissertações, em documentos legais e livros que tratam da temática supracitada.

Visando responder à questão principal, encontramos questões corolárias que contribuíram para o resultado encontrado. Pensar na formação do professor indígena nos levou a indagar sobre que tipo de educação aqui se trata? O que caracteriza a escola indígena em suas particularidades? Como realizar a formação desse professor para desempenhar o magistério indígena e suas especificidades?

Partimos da definição e da contextualização da educação indígena enquanto conceito diferenciado da escolarização. Abordamos o sucesso dessas práticas educativas e a forma como elas ocorrem no seio da comunidade.

Desdobramos a temática para conceito de escolarização, reconhecido como uma forma de educação, com os significados positivos e negativos vivenciado pelas etnias, desde a colonização até muito recente. A legislação atual é exposta ao passar do contexto histórico para a atualidade. Optamos por dedicar um tópico ao bilinguismo e interculturalismo por entender que são pilares que sustentam o novo modelo de educação indígena que ainda está sendo construído.

Posto este cenário, quem vai conduzir essa nova educação indígena? $\mathrm{O}$ professor indígena cujas funções em sua comunidade não serão efetivadas a partir de uma formação docente que se aplica ao professor nacional. Os aspectos formativos necessários ao professor indígena são analisados a partir das funções que exerce em sua comunidade. É para essas funções específicas que ele precisa estar apto.

Embora incipiente, a pesquisa em epígrafe fornece elementos para a reflexão sobre as questões pertinentes a educação indígena e a formação de seus professores. 


\section{Apontamentos sobre a Educação Indígena}

A Constituição Federal de 1988, no artigo 210, estabelece que o Ensino Fundamental deve ser ministrado em Língua Portuguesa, respeitando e assegurando às sociedades indígena a utilização de suas línguas maternas, e não apenas isso, a CF/88 em seu artigo 231 reconhece também as estruturas sociais indígenas, costumes, línguas, crenças e tradições, e os direitos originários sobre as terras que tradicionalmente ocupam, competindo à União demarca-la, proteger e fazer respeitar todos os seus bens.

Dessa forma, tudo o que foi assegurado no texto legal concernente às populações originárias foi resultado de lutas pelos direitos étnicos desde a década de 1970, no entanto, embora seja realmente uma força motriz, a efetivação desses direitos perpassa por diversos conceitos a serem construídos e desconstruídos. Aqui trataremos basicamente do direito à educação escolar com todas as peculiaridades que lhes adjetivam (Grupioni, 2006).

Nesse sentido, será apresentada uma breve análise dos paradigmas relacionados a uma educação indígena de qualidade através de pesquisa bibliográfica e documental, porém antes de enveredar pelos caminhos do que há para ser erigido, é preciso situar a premissa mais basilar na arquitetura desse modelo de educação ora proposto pelo texto constitucional e reiterado por outros textos legais como a Lei de Diretrizes e Bases da Educação Nacional 9.394/96 (LDBEN) que é o conceito do sujeito índio, que infelizmente ainda é visto de forma folclórica e caricata pela sociedade nacional. Há, mesmo nas escolas de não indígenas, um doutrinamento que mostra o índio como um sujeito ingênuo, com uma pena na cabeça, que mora na oca e toma chá com o pajé, como se pode observar nas comemorações escolares ao dia do índio em diversas instituições. Maher (2006) afirma que o objetivo dessa prática é o de não identificar os povos indígenas roubando suas identidades e generalizando um mito descabido. Em contraponto a essa ideia, a autora propõe uma identificação positiva da figura do cidadão indígena, afirmando que: 
O índio é um ser humano exatamente igual a todos nós e, por isso mesmo, capaz de, em momentos, agir com grande generosidade, e, em outros de se comportar de modo menos louvável, de modo não tão nobre. Índio ri, índio chora, tem ciúme, tem inveja, tem ambições pessoais, é capaz de fazer renúncias dificílimas. Muitos protegem nossas florestas, alguns comercializam madeira de lei (Maher, 2006. p. 21).

Baniwa (2013) afirma haver tantas identidades indígenas quanto são os índios existentes, não sendo possível enquadrá-los numa figura estática, criada pela sociedade envolvente ou como um modo de estar transitório, em vias de se tornar um cidadão nacional. Desses conceitos deriva também a concepção de uma cultura indígena imóvel no tempo, na qual a indianidade está vinculada ao não uso das tecnologias e conhecimentos atualizados. $\mathrm{O}$ índio que usufruir de TV, internet, energia elétrica, carro, dentre outras coisas é considerado como não índio ou menos índio.

É pois, a partir do respeito a esse índio humanizado, consciente e sujeito dos seus objetivos que se pode construir a educação escolar indígena que se deseja, cabendo aqui clarificar dois outros conceitos que referendam esse novo olhar sobre a educação étnica, a saber educação indígena e educação escolar indígena.

A educação indígena é aquela que ocorre no seio da comunidade, dentro das especificidades de cada povo. Não há um horário ou um local reservado para que ela ocorra. Nas sociedades indígenas, o ensinar e o aprender são ações mescladas, incorporadas à rotina do dia a dia, ao trabalho e ao lazer e não restritas a nenhum espaço específico (Maher, 2006). Trata-se, portanto de uma pedagogia com resultados comprovados, dado que assegurou a permanência e a sobrevivência desses povos por séculos nos quais se tentou dizimar suas vidas e suas culturas.

Numa visão etnocêntrica, pressupunha-se que os índios não tinham educação, porque não tinham as mesmas formas e os mesmos modelos educacionais ocidentais. [...] Em outras palavras, a escola e a alfabetização entram em cena como sinônimos de educação, cultura e civilização, como se os índios não a tivesse (Baniwa, 2006, p.146). 
Dialogando com Baniwa, Orellana (2011, p.33) relata a necessidade de reconhecer "que os grupos étnicos são possuidores de um sistema tradicional de educação, que se manifesta sutil e subjetivamente no cotidiano de suas vidas, no contexto familiar e individual”, corroborado por Maher (2006, p. 18), em uma colocação incisiva sobre esse tema: "Conhecimento tem que ser útil para garantir a sobrevivência do grupo" sendo esse o mote do seu processo educacional: o aprendizado para o dia a dia na aldeia, com objetivo de sobreviver, conviver e contribuir para a vida em comum.

Gersem Baniwa (2006, p. 131) relata que os principais saberes indígenas estão ligados ao trabalho, a comida, bebida, remédios, a medicina e mesmo às suas línguas, que trazem toda uma cosmologia aplicada. O mesmo autor assinala o objetivo dessa pedagogia étnica: "Ser um bom xavante, um bom guarani, um bom baniwa é o objetivo que guia a ação pedagógica xavante, guarani e baniwa”.

\section{Educação escolar indígena: bases e princípios}

Grupioni (2006), Maher (2006), Matos e Monte (2006), Orellana (2011) e Venere (2011) abordam a temática da escolarização das populações nativas através da premissa das ideologias subjacentes a cada ação que aparentava prestar um serviço ao povo indígena, a partir de uma decisão tomada exclusivamente pelo colonizador.

De forma bastante sintética, Orellana (2011 p. 14) resume a ideia do que foi esse processo de imposição cultural da população colonizadora sobre os povos nativos: "historicamente os programas de escolarização nas áreas indígenas foram criados segundo a ideia de que é necessário "fazer a educação do índio".

Matos e Monte (2006, p. 72) reiteram ainda que:

No Brasil, como no conjunto dos países americanos, a educação escolar foi empregada como um recurso, quase sempre extremamente eficaz, da aniquilação da diversidade. Inúmeras iniciativas de civilização e integração forçada a sociedade nacional foram implementadas pela coroa portuguesa, pelo império e pela república. 
Num primeiro momento, a introdução da escola em meio indígena foi com objetivo de domesticar os considerados selvagens, conseguindo submetê-los, tornando-os úteis a comunhão nacional, após terem suas línguas e suas peculiaridades étnicas e culturais destruídas (Grupioni, 2006).

Após o fracasso parcial da teoria de domesticação, um novo paradigma é assumido, com objetivo assimilacionista/integracionista, ou seja, com as mesmas intenções corrente ideológica anterior, nesse conceito se mudava a forma utilizada para atingir a mesma meta: as escolas das aldeias em nada se diferiam das escolas rurais. Um professor branco ensinava a ler em língua portuguesa, sendo o aluno ideologicamente conduzido a acreditar na inferioridade da sua cultura e da sua língua. Nesse contexto, afirmam Matos e Monte (2006, p. 72): "Mesmo assim, recorrendo a diversas formas de resistência, as sociedades indígenas tentaram "domesticar" a escola ou, quando isso não era possível, tornaram-se totalmente refratárias a ela”.

$\mathrm{Na}$ avaliação de Terezinha Machado Maher (2006) foi a ineficiência do projeto de assimilação que levou ao processo assimilacionista de transição, no qual a criança passou a ser alfabetizada em língua materna e, a partir do seu entendimento do funcionamento da leitura e escritas da língua materna, se introduziria a língua portuguesa, paulatinamente até que a primeira língua fosse excluída do currículo.

Após a promulgação da Constituição Federal em 1988, e com o advento da LDBEN 9.394/96 ficou assim determinado:

Art. 78. O Sistema de Ensino da União, com a colaboração das agências federais de fomento à cultura e de assistência aos índios, desenvolverá programas integrados de ensino e pesquisa, para oferta de educação escolar bilingue e intercultural aos povos indígenas, com os seguintes objetivos:

I - proporcionar aos índios, suas comunidades e povos, a recuperação de suas memórias históricas; a reafirmação de suas identidades étnicas; a valorização de suas línguas e ciências;

II - garantir aos índios, suas comunidades e povos, o acesso às informações, conhecimentos técnicos e científicos da sociedade nacional e demais sociedades indígenas e não-índias. 
Muitas outras legislações infraconstitucionais e orientações oficiais se seguiram em anos posteriores, principalmente devido à luta de várias etnias para terem seus direitos efetivados no cotidiano. $\mathrm{Na}$ avaliação de Grupioni (2006, p. 45) "[...] de algo historicamente imposto, a escola passou a ser reivindicada pelos indígenas, que pressentiram nela a possibilidade de construção de novos caminhos para se relacionarem e se posicionarem frente aos representantes da sociedade envolvente".

Ressalvados os aspectos bilíngues e interculturais, a serem tratados mais adiante, a reflexão que se apresenta é: acerca de que escola indígena está se falando? Para esta indagação Baniwa (2013,p. 1) nos apresenta a seguinte resposta: "Não existe um modelo, um objetivo e nem uma meta única. Cada povo indígena concebe historicamente sua escola e projeta-a segundo suas perspectivas contextualizadas”. Afinal, cada etnia, possui seu modelo de educação, sua forma de ser, suas tradições e culturas. Desse modo,

Enquanto para algumas comunidades indígenas, a escola precisa estar mais direcionada ou focada para possibilitar adequadamente o acesso a alguns conhecimentos da sociedade nacional como, por exemplo, a língua portuguesa, a matemática e a informática, que consideram estratégicos para atender suas necessidades práticas na defesa de seus direitos, outros preferem uma escola que esteja mais direcionada para revitalização, transmissão e valorização da cultura e identidade do povo (Baniwa, 2013, p. 2).

A proposta é, em si, audaciosa por diversas situações convergentes, dentre elas a variedade étnica muito grande e espelhada no território nacional, as distâncias e as dificuldades de acesso, a falta de recursos aplicados à educação indígena, além das invasões e violência da sociedade envolvente contra os povos indígenas. No entanto,

Privar ou reduzir a possibilidade das crianças e dos jovens indígenas de terem acesso pleno aos conhecimentos da sociedade dominante pode ser também uma forma de exclusão, geradora de desigualdades entre indivíduos e coletivos étnicos no plano cultural, econômico, profissional e humano, tão perversa quanto à negação do direito à valorização e à continuidade das identidades e culturas tradicional (Baniwa, 2013, p. 8). 
A escola indígena, hoje na busca incessante dos povos étnicos e das organizações representativas, é vista como instituição a ser aprimorada para atender o mínimo previsto em lei e para tornar suas populações mais autônomas, capazes de conviver com a sociedade nacional de forma mais igualitária.

Há, portanto, um entendimento comum entre os povos indígenas de que a escola deve contribuir para possibilitar uma relação menos desigual e desvantajosa com a sociedade nacional e global, desde que não seja em detrimento dos seus conhecimentos, culturas e identidades (Baniwa, 2013, p. 8).

Esse entendimento na verdade deveria ser o ideal para todos as escolas, posto que, ao falarmos de educação referimo-nos à um processo de humanização, o que inclui o que a própria $\mathrm{CF} / 88$ preconizou em seu artigo 205, “[...] a educação, direito de todos e dever do Estado e da família, será promovida e incentivada com a colaboração da sociedade, visando ao pleno desenvolvimento da pessoa, seu preparo para o exercício da cidadania e sua qualificação para o trabalho"(Brasil, 1988). O direito à educação ao incluir todos, comtempla em seu escopo, a educação quilombola, do campo, dentre outras, e de igual modo, a educação indígena.

Para tanto, deve ser exatamente por isso que as diretrizes curriculares nacionais para a educação básica no 04 de 13 de julho de 2010, preveem que:

Art. 37. A Educação Escolar Indígena ocorre em unidades educacionais inscritas em suas terras e culturas, as quais têm uma realidade singular, requerendo pedagogia própria em respeito à especificidade étnico-cultural de cada povo ou comunidade e formação específica de seu quadro docente, observados os princípios constitucionais, a base nacional comum e os princípios que orientam a Educação Básica brasileira.

Parágrafo único. $\mathrm{Na}$ estruturação e no funcionamento das escolas indígenas, é reconhecida a sua condição de possuidores de normas e ordenamento jurídico próprios, com ensino intercultural e bilíngue, visando à valorização plena das culturas dos povos indígenas e a afirmação e manutenção de sua diversidade étnica. 
Art. 38. Na organização de escola indígena, deve ser considerada a participação da comunidade, na definição do modelo de organização e gestão, bem como:

I - suas estruturas sociais;

II - suas práticas socioculturais e religiosas;

III - suas formas de produção de conhecimento, processos próprios e métodos de ensino-aprendizagem;

IV - suas atividades econômicas;

$\mathrm{V}$ - edificação de escolas que atendam aos interesses das comunidades indígenas;

VI - uso de materiais didático-pedagógicos produzidos de acordo com o contexto sociocultural de cada povo indígena.

Uma educação singular, para uma realidade singular, que comtemple as dimensões étnicas e culturais dos posso indígenas, por isso, cabe trazer à baila a questão do bilinguismo e da interculturalidade, assunto que iremos discorrer a seguir.

\section{Bilinguismo e interculturalidade}

Está explícito no texto da LDBEN no 9.394/96, no artigo 78, dois adjetivos que caracterizam a educação indígena como diferenciada, que são o bilinguismo e a interculturalidade, que são a base de uma educação para a diversidade e o respeito a cultura dos povos étnicos. Entretanto, o texto legal é apenas uma base, cabendo ao protagonismo indígena a luta para que se reconheçam as igualdades nas diferenças e as diferenças nas igualdades.

Em relação ao bilinguismo, Matos e Monte (2006, p. 71) explicam

Há grande quantidade de sociedades indígenas cujas primeiras línguas são aquelas dos seus antepassados. Outras adotaram variantes regionais do português diante do desaparecimento de suas línguas originárias nos últimos cinco séculos. Em geral, há uma tendência ao bilinguismo como parte do processo de contato com a sociedade nacional. Entretanto existem ainda casos de indivíduos monolíngues em língua indígena, geralmente os velhos e as crianças e não são raros os indivíduos monolíngues em língua portuguesa, sobretudo as novas gerações. Também se encontram casos de 
multilinguismo em terras indígenas do país, onde se entendem e/ou se falam fluentemente ou parcialmente duas ou mais línguas indígenas, junto a uma ou duas línguas dominantes como espanhol e português, sobretudo em regiões de fronteira.

Orellana (2011, p. 56) propõe uma alternativa para trabalhar a questão do bilinguismo:

Para uma capacitação em bilinguismo requer-se ampla compreensão dos contextos sociais bilíngues e, em particular, a compreensão dos das causas históricas e sociais da realidade bilíngue das comunidades envolvidas e das particularidades das situações bilíngues.

Ao ficar presa a um bilinguismo "ideal" e/ou como língua escolar, é grande o risco de extinção da língua materna ao ser tratada como de menor valor e desprezada em detrimento da língua do colonizador por seu maior status social (MAHER, 2006).

Segundo Monserrat (2006, p.131) "vale destacar que o futuro de uma língua indígena não pode ser definido pela escola, antes ele depende de que seus falantes queiram conservá-la, desenvolvê-la e utilizá-la no dia a dia" e complementa: "Dois pré-requisitos são necessários para que uma língua minoritária tenha possibilidade real de sobrevivência: que ela tenha um lugar na sociedade maior e que desempenhe um papel funcional na sociedade que a utiliza como língua vernácula” (Monserrat, 2006, p. 140).

A equalização desse direito ao bilinguismo é da comunidade na qual se localiza a escola e é por ela atendida, tendo em vista que a uma distância de 100 metros, pode haver escolas indígenas com diferenças cruciais em suas realidades, indicando que o tratamento dado ao bilinguismo e a interculturalidade priorize em sua organização o protagonismo indígena que respeita o igual e o diferente.

Muito do que se aplica ao bilinguismo, cabe também na questão da interculturalidade, Maher considera que "o ato de conseguir fazer dialogar comportamentos e conhecimentos construídos sobre bases culturais distintas 
e frequentemente conflitantes é atualmente entendida como esteio, a razão de ser da escola indígena” (Maher, 2006, p. 27).

Para Venere (2011, p. 39), a interculturalidade, como "o intercambio positivo e mutuamente enriquecedor entre as culturas das diversas sociedades, deve ser característica da escola indígena" e Orellana (2011, p. 51) acrescenta:

A educação intercultural é vista como instrumento de inclusão das minorias e de atribuição de poder às populações que estão às margens da cultura dominante. A ideia subjacente a essa visão é a de que, através do domínio tanto dos seus códigos específicos como dos códigos 'ocidentais' ou nacionais, as minorias poderiam reivindicar um espaço na sociedade e na economia nacionais e globais.

Ao reconhecer o fato de que os povos indígenas sempre tiveram relações interculturais com a sociedade envolvente, mesmo sendo essa convivência permeada por conflitos e imposições, inclusive no contexto escolar, o que se propõe é que essas relações sejam repensadas e que haja uma mudança nas formas de interação (Markus, 2006).

Neste contexto, o mesmo autor elenca os principais objetivos ligados à educação intercultural, que se apresenta como uma estratégia de novas relações entre etnias e culturas diferentes, em que se busca promover identidades, reconhecer e valorizar a alteridade, mas ao mesmo tempo sustentar a relação e interação crítica e solidária e entre elas (Markus, 2006, p. 107).

A proposta da interculturalidade é o caminho do diálogo e do respeito às diferenças. Para tanto, não pode prescindir do reconhecimento do valor do outro, de suas crenças, saberes e cultura, sendo a validação em termos científicos do saber e dos conhecimentos tradicionais que foram construídos com método, pesquisa e sistematização pelas culturas e sociedades indígenas via necessária para esse diálogo real (Meliá, 1996 apud Markus, 2006, p. 109).

A percepção de que a educação indígena, com todas as suas peculiaridades representa ainda um desafio, requer o entendimento que o primeiro passo para garantir a existência desse tipo de escola é que o condutor de todo o processo escolar seja, evidentemente, um professor indígena (Maher, 2006). 


\section{Um professor indígena para uma escola indígena}

Embora as tentativas de escolarizar os povos indígenas ocorram desde a colonização com objetivo de integrá-los à sociedade nacional, preposto afirmado claramente em todas as Constituições anteriores a 1988, o atual modelo de construção de uma rede de educação escolar indígena, com respeito à diversidade e à cultura própria de cada comunidade leva ao surgimento da figura central para a efetivação desse novo projeto: o professor indígena. Sendo parte da sociedade na qual atua, ele tem uma contribuição ímpar, que atenda aos interesses de cada comunidade (Grupioni, 2006; Maher, 2006).

O protagonismo desse profissional é explicitado por Maher (2006, p.11) ao afirmar que "a escola indígena se configura como uma situação limite em termos de educação. Nela as dificuldades, os dilemas são sempre colocados de forma muito contundente, o que obriga o professor a ter que olhá-los prontamente de frente”.

Enquanto cabe ao professor não-índio formar seus alunos como cidadãos brasileiros plenos, é responsabilidade do professor indígena não apenas preparar as crianças, os jovens e os adultos sob sua responsabilidade, para conhecerem e exercitarem seus direitos e deveres no interior da sociedade brasileira, mas também garantir que seus alunos continuem exercendo amplamente sua cidadania no interior da sociedade indígena a qual pertencem. (Maher apud Grupioni, 2006, p. 24).

Em virtude desse papel que exerce em sua comunidade, o professor indígena tem que estar sempre atento e com visão crítica para conciliar os preceitos refletidos no conhecimento da sociedade envolvente e na formação para o exercício da "florestania" ${ }^{1}$ cabendo ao estado ofertar estudos que o prepare para tal.

Outra peculiaridade é que desde a LDBN 9394/96, o professor não índio, para iniciar carreira no magistério público deve possuir formação inicial para a docência. Por outro lado, o professor indígena, escolhido em geral pela comunidade, tem pouca escolaridade e um conhecimento restrito dos saberes

1 O termo florestania é utilizado por Maher (2006) para indicar uma cidadania étnica, própria das populações nativas. 
acadêmicos (Maher, 2006). Como consequência, os cursos de formação em magistério étnico precisam de um currículo que supra essa lacuna.

E Grupioni (2006, p. 52) reafirma sobre essa questão da escolaridade e da formação do professor indígena:

Ela está presente na legislação que trata do direito dos índios a uma educação intercultural diferenciada dos demais segmentos da população brasileira. Nesta legislação, garante-se que os professores indígenas possam ter formação 'em serviço', ou seja, paralelamente à sua atuação em sala de aula, e concomitante à sua formação básica.

O currículo da escola é outra dificuldade com a qual se deparam os professores indígenas. Enquanto o professor não índio recebe o currículo pronto, para fazer seu planejamento e suas adequações, a maioria dos índios precisa definir um currículo, juntamente com a comunidade, elaborar o projeto político pedagógico e gerenciar a escola indígena.

Com relação aos recursos didáticos pedagógicos em acordo com a realidade de cada povo, são praticamente inexistentes, não havendo distribuição por parte das redes de ensino e dessa forma mais uma obrigação recai sobre o docente, embora as diretrizes curriculares nacionais para a educação básica no 04 de 13 de julho de 2010, tenha previsto o uso de materiais didático-pedagógicos produzidos de acordo com o contexto sociocultural de cada povo indígena.

No entanto, essa falta de material didático-pedagógico adequado à essa população, ainda é uma questão desafiadora, nessa direção Maher (2006, p.25) afirma: que "[...] a maior parte dos materiais que lhe poderiam ser úteis estão 'por fazer". Desta feita, os cursos de formação em magistério indígena precisam dedicar tempo e, também, formar o professor pesquisador, elaborador de materiais didáticos e de apoio.

Para vários autores a questão da formação intercultural é necessária ao professor indígena, posto que o mesmo exerce atribuições e desempenha um papel que está além da escola. Por seu conhecimento e suas habilidades, geralmente ele é o intermediador do diálogo com a sociedade envolvente, lhe cabendo a tarefa de sustentar os posicionamentos dos seus parentes, liderar 
discussões e negociações envolvendo assuntos tão diversos quanto a posse de seus territórios, construção de estradas, ou mesmo atendimento à saúde (Baniwa, 2013; Grupioni, 2006; Maher, 2006; Orellana, 2011; Venere, 2011).

A educação bilíngue requer desse professor decisões referentes a grafia de sua língua materna, uma vez em que na maioria delas não existe um código gráfico convencionado. Para tanto, em sua formação, a linguística precisa constar do currículo e oferecer competências mínimas para enfrentar esse desafio.

Dada às particularidades das demandas que lhe são próprias, Matos e Monte (2006, p. 106) afirmam que:

A urgente tarefa de formação inicial completa dos docentes indígenas, em nível médio e superior, não se pode fazer descolada da discussão da escola indígena e de seu currículo, de forma que estejam os primeiros preparados para oferecer aos seus parentes, dentro das terras indígenas, a totalidade da educação básica, ou seja, a continuidade do Ensino Fundamental (5 a 8 séries) e o Ensino Médio segundo as realidades e necessidades imediatas e de longo termo formuladas por estas sociedades.

De modo associado a essas particularidades, uma das funções fundamentais do professor indígena é registrar os conhecimentos tradicionais e tornar-se uma espécie de guardião dos saberes de seu povo (Maher, 2006). Faz se necessário que ele desenvolva competência para essa atividade e os cursos de formação inicial e continuada são os loci para desenvolvê-la.

Nesse sentido, o fato de terem acesso aos códigos da sociedade brasileira faz com que se percebam, e com que sejam percebidos, como elementos cruciais na interlocução cultural e política de seu grupo étnico com a sociedade nacional (Maher, 2006). O professor indígena representa uma autoridade moral em sua comunidade e deve estar apto a resolver as demandas que lhe são inerentes

\section{Considerações finais}

A reflexão sobre a formação do professor indígena parte em primeiro lugar do entendimento das especificidades de um processo de escolarização apoiado na diversidade étnica dos povos indígenas em seus múltiplos aspectos. 
Inicialmente requer a compreensão de uma diferença que para as sociedades indígenas é crucial: a questão da educação versus escolarização. A primeira é reconhecida por eles como um processo endógeno que ocorre de forma natural no convívio da aldeia, sendo já comprovada a sua eficiência através da sobrevivência desses povos e suas tradições e cultura.

A escolarização chegou com o colonizador, de forma exógena e, durante muito tempo, foi usada para massacrar as populações nativas. Com o correr dos anos e mais intensamente a partir da década de 1980, os movimentos étnicos lutaram para apropriar-se da escola e fazer dela meio de aprendizagem dos saberes da sociedade envolvente e também de preservação da própria cultura. A Constituição Federal de 1988 foi o primeiro passo, em termos de legislação, em busca do modelo ideal de escola indígena que se caracteriza como bilíngue e intercultural.

O bilinguismo, premissa basilar da educação indígena que visa a perpetuação da língua étnica, para além dos aspectos positivos, não pode ser utilizado como receita pronta e adequada a todas as comunidades e etnias, c exigindo análise particular de cada situação pois quando se refere as situações linguísticas desses povos, há diversidades e peculiaridades a serem consideradas, tais como a existência de línguas ágrafas; povos monolíngues em língua materna; povos monolíngues em língua portuguesa; povos bilíngues em língua materna e língua portuguesa e até povos plurilíngues em português, espanhol e língua indígena, próximo as fronteiras.

Dada esta realidade e de outras mais variadas situações no mesmo sentido, o bilinguismo garantido em lei só atingirá seu objetivo se os sistemas de ensino trabalharem na adequação do ideal ao que é real, fazendo uma simbiose cultural em que ambos os envolvidos possam interagir positivamente.

A interculturalidade também é um conceito que requer reflexão, debate e definição em parceria com as comunidades indígenas. $\mathrm{O}$ contato intercultural do índio com a sociedade envolvente ocorreu desde a chegada do colonizador, mas num modelo em que a cultura dos povos da terra era considerada inferior e deveriam aceitar com gratidão a cultura da sociedade nacional, renunciando seus costumes, saberes e tradições até se tornarem "civilizados". 
A nova definição desse conceito objetiva a valorização de ambas as culturas, a serem tratadas com igualdade. As práticas interculturais necessárias são aquelas que possibilitam aos indígenas se relacionarem de forma positiva com a sociedade envolvente, sendo respeitados em suas diferenças.

É para dar sustento a todo o arcabouço dessa educação escolar indígena diferenciada, baseada no respeito as tradições e a cultura dos povos étnicos que surge a figura do professor indígena, que sendo parte da comunidade, necessita de formação para atuar numa realidade peculiar e específica.

Ao professor indígena cabe formar seus alunos para serem capazes de atuar com eficiência tanto na sociedade nacional quanto na sua comunidade. Que entenda além da diferença da língua, um universo de questões que devem ser consideradas em busca de uma convivência respeitosa.

Para formar o professor capaz de agir em meio a tanta diversidade, há tópicos fundamentais que precisam constar no currículo de sua formação segundo os Referenciais para a Formação de Professores Indígenas (2002), dentre os quais destacamos:

1.O bilinguismo e a diversidade linguística dos povos;

Princípios básicos de linguística, para auxiliar na elaboração de um código de escrita para línguas ágrafas;

2.Formas de elaborar o registro escrito das histórias e tradições de suas comunidades;

3.Subsídio para a construção de material didático e de apoio que tenha significado para o seu povo e,

4.Metodologia de elaboração do currículo e do projeto político pedagógico, com a participação de todos os habitantes da comunidade.

Entretanto, ser professor indígena é função que não se esgota na sala de aula, pois por seus conhecimentos dos códigos da sociedade envolvente, ele é o intermediador em situações nas quais a comunidade necessita estabelecer um diálogo ou fazer reivindicações. Formar esse profissional requer respeito a diversidade e à complexidade de suas atribuições e um currículo abrangente que o prepare para trabalhar igualdades e diferenças. 
Embora seja um campo de estudo recente, ainda com muitas adequações a serem feitas, a expectativa é de contribuir para o debate sobre a formação do magistério indígena num momento em que o tema ganha relevância pela expansão e organização das redes de educação indígena e o aumento da demanda de formação desse professor.

\section{Referências}

BANIWA, Gersen. O índio brasileiro: o que você precisa saber sobre os povos indígenas no Brasil de hoje. Brasília: LACED/Museu Nacional, 2006.

BANIWA, Gersen. Educação escolar indígena no Brasil: avanços, limites e novas perspectivas. 36a Reunião da ANPed. 29 a 02 de outubro de 2013. Goiânia-GO. Disponível em http://36reuniao.anped.org.br/pdfs_trabalhos_encomendados/gt21_trabalhoencomendado_gersem.pdf. Acesso em: 27 jan. 2020

BRASIL. Constituição da República Federativa do Brasil: promulgada em 5 de outubro de 1988. 4. ed. São Paulo: Saraiva, 1990.

BRASIL. Ministério de Educação e Cultura. Lei de diretrizes e bases da educação nacional. Lei no 9394/96, de 20 de dezembro de 1996. Estabelece as diretrizes e bases da Educação Nacional. Brasília: MEC, 1996

BRASIL. Ministério da Educação. Referenciais para a formação de professores indígenas. Secretaria de Educação Fundamental. Brasília: MEC; SEF, 2002.

BRASIL. Ministério da Educação e Cultura. Lei no 04, de 13 de julho de 2010. Define as Diretrizes Curriculares Nacionais Gerais para a Educação Básica. Brasília: MEC, 2010.

GRUPIONI, Luis Donisete Benzi. Contextualizando o campo da formação de professores indígenas no Brasil. In GRUPIONI, Luis Donisete Benzi. (org.). Formação de professores indígenas: repensando trajetórias. Brasília: MEC/SECAD, 2006. cap. 02. p. 39-68. 
MAHER, Terezinha Machado. A formação de professores indígenas: uma discussão introdutória. In: GRUPIONI, Luis Donisete Benzi. (org.). Formação de professores indígenas: repensando trajetórias. Brasília: MEC/SECAD, 2006. Cap. 01, p. 11-37

MARKUS, Cledes. Identidade étnica e educação escolar indígena. 2006 p.115. Dissertação de mestrado em educação, Universidade Regional de Blumenal: 2006. Disponível em: http://bdtd.ibict.br/vufind/Record/FURB_5cfbf40f7d8903b7b7d65a49479908dc Acesso em: 28 de dez. 2019.

MATOS, Kleber Gesteira; MONTE, Nietta Lindenberg.O estado da arte da formação de professores indígena no Brasil. In: GRUPIONI, Luis Donisete Benzi. (org.). Formação de professores indígenas: repensando trajetórias. Brasília: MEC/SECAD, 2006. Cap. 03. p.69-112.

MONSERRAT, Ruth Maria Fonini. Política e planejamento linguístico nas sociedades indígenas do Brasil hoje: o espaço e o futuro das línguas indígenas. In: GRUPIONI, Luis Donisete Benzi. (org.). Formação de professores indígenas: repensando trajetórias. Brasília: MEC/SECAD, 2006. cap 05.p. 131-154.

ORELLANA, Aly David Arturo Yamall. Formaçãode professores indígenas em Rondônia: a interculturalidade e seus desafios.2011. p. 90. Dissertação de mestrado, PUC: São Paulo, 2011. Disponível em: https://tede2.pucsp.br/ handle/handle/10307 Acesso em: 22 de dez. 2019.

VENERE, Mario Roberto. Projeto Açaí: uma contribuição à formação de professores indígenas no Estado de Rondônia.2011.p. 181. Tese de doutorado em Educação escolar - Universidade Estadual Paulista, Faculdade de Ciências e Letras, Campus de Araraquara, 2011. em Disponível: http://bdtd.ibict. br/vufind/Record/UNSP_f49f88c7a37e72072930fb79d6a739a5/Description Acesso em: 28 de dez. 2019. 


\section{ESTADO E POLÍTICAS PÚBLICAS EM EDUCAÇÃO: A IMPLEMENTAÇÃO DO PACTO NACIONAL PELA ALFA- BETIZAÇÃO NA IDADE CERTA}

Juliana Cândido Matias

Josemir Almeida Barros

\section{Introdução}

Pensar políticas públicas, bem como as políticas sociais e sua estreita relação com o Estado requer um olhar "além do muro", para que se veja a ligação extrema entre as formas de se fazer estas políticas por entre os interesses das relações de poder globalizadas. Não há ilhas neste manancial, sim uma teia interligada pelas necessidades do mercado capitalista para que o seja mantido em toda a sua estrutura, garantindo o lucro e a produtividade a qualquer custo, e é neste contexto que as políticas educacionais são planejadas e implementadas no Brasil.

Deste modo, esta pesquisa objetiva analisar como estas relações influenciam as propostas de programas, projetos e pactos para educação, no que tange a formação docente, por meio do Pacto Nacional Pela Alfabetização na Idade Certa - PNAIC - bem como as contribuições de pesquisas recentes sobre o tema, pois compreender esta rede conceitual é desvelar a atualidade política e educacional do país na atualidade, bem como sua configuração de Estado, historicamente estabelecida; fatores essenciais à pesquisa social.

De acordo com Matias et al. (2019) a pesquisa qualitativa é importante e apresenta suas particularidades. Buscou-se por meio de fontes documentais, tais como legislação, dados estatísticos sobre a Educação e materiais bibliográficos por meio de consultas à Biblioteca Digital de Teses e Dissertações - BDTD ${ }^{1}$ e a base de dados do Portal do Periódico CAPES a partir do acesso cafe ${ }^{2}$.

1 Ver: https://bdtd.ibict.br/vufind/

2 Ver: https://www-periodicos-capes-gov-br.ezl.periodicos.capes.gov.br/index.php? 
A análise da implementação do pacto para formação docente PNAIC - possibilitou evidenciar como as políticas educacionais estão a serviço dos interesses do mercado, marcadas pela descontinuidade e ineficiência, tradição "[...] de programas criados a cada gestão governamental, segundo critérios clientelísticos e burocráticos” (Faleiros, 2006, p. 28, grifo nosso), a tal sorte de manterem-se pouco alterados nas últimas décadas, e que tem sido timidamente discutido em pesquisas recentes no Brasil, dificultando assim mudanças neste território educacional em crise.

\section{Estado e políticas públicas: concepções da indissociabilidade}

Impostos a pagar, governança intangível, garantia da lei e da ordem. Quem recebe o imposto? Quem governa? A garantia da lei e da ordem sob a ordem de quem? A resposta em um primeiro relance se apresenta clara: o Estado. Porém, a questão escondida nas entranhas formais e historicamente estabelecida é: Qual estado?

Para Abbagnano (2007, p. 364) as concepções de Estado se caracterizam em três entendimentos básicos: "10 a concepção organicista, segundo o qual o E. é independente dos indivíduos e anterior a eles; $2^{\circ}$ a concepção atomista ou contratualista, segundo o qual o E. é criação dos indivíduos; $3^{\circ} \mathrm{a}$ concepção formalista, segundo o qual o E. é uma formação jurídica”. Assim, embora seus conceitos tenham mudado com o passar do tempo, bem como os acontecimentos históricos tenham doado sentidos outros a estas concepções, a ideia de uma sociedade politicamente organizada para resolver seus problemas e promover o bem-estar geral, ainda persiste no senso comum.

Quer seja o Estado organicista dos gregos, contratualista dos estoicos romano, ou formalista moderno que considera a soberania, povo e território elementos essenciais do Estado, o reflexo instransponível de olhos que tudo veem e tudo resolvem, é presente e remete aos mais variados lugares; às vísceras da sociedade: saúde, educação, propriedades privadas, segurança, soberania nacional, entre outros, que muda de forma e de forma ao redor do mundo, conforme os interesses políticos e econômicos estabelecidos, num movimento 
permanente e que, por suas características estruturais podem ser reconhecidas como: Estado Democrático, Estado de Direito e Estado Mínimo. E é neste contexto que as políticas públicas têm sido pensadas no caminhar da história.

O Estado Democrático, nascido no Estado Moderno, estrutura-se pelas políticas sociais de igualdade que atendam a demanda da sociedade em suas instâncias diversas, garantindo a relação direta entre a sociedade, o Estado e as políticas públicas implementadas pelo Poder Executivo:

[...] o Estado democrático de direito, modelo estruturado, fundamentalmente, na conformação de uma vontade geral, conciliadora da vontade do indivíduo e da vontade do estado. Consolida-se como estrutura vocacionada à permanência, comprometida com a função social e a garantia de direitos fundamentais e sociais, constitucionalmente assegurados, assumindo, a democracia, portanto, papel civilizatório na relação sociedade-Estado (Pires; Costa, 2012, p. 172).

Portanto, o que caracteriza o regime democrático é justamente a manutenção do Estado democrático de direito, responsável pela proteção de direitos individuais e sociais. Esta forma de Estado contribui para a boa relação da sociedade e poder executivo, legislativo e judiciário, além de possibilitar novos modelos e demandas político e social, bem como seu reconhecimento para a sistematização de políticas públicas igualitárias.

O Estado de Direito passa por conflitos em suas definições, pois como esclarece Batista (2012, p. 169) “[...] seu significado acaba por depender da noção que se tem de direito [...]” o que ficará a critério da legislação de cada país, relativizando seu conceito e seus limites constitucionais. Porém há uma estrutura organizacional desta forma de Estado que se mantém característico e passível de ser reconhecida, dado as suas prioridades:

A preocupação do Estado de Direito é para com a garantia dos direitos fundamentais, o que implica na diminuição dos poderes e intervenção do Estado, diminuição pautada em restrições legais. Historicamente, a expressão Estado de Direito é utilizada para caracterizar, sob o prisma do Direito Constitucional, a realidade do Estado Liberal [...] (Batista, 2012, p. 169). 
Neste contexto, o Estado de Direito é fruto de uma sociedade capitalista e que cria necessidades a todo instante, com uma constante urgência em expandir, colonizar, apropriar-se, ter. Embora passe por diferentes conceituações devido as interpretações legais pelo mundo, esta forma de Estado não esconde seu flerte com a diminuição da intervenção do Estado, deixando a porta entreaberta para o Estado Mínimo institucionalizar-se.

Com a diminuição das ações do Estado sobre o domínio econômico, entra em cena o Estado Mínimo que é “[...] capitalista e também burguês. No entanto, o domínio econômico não sofre interferência do poder político, visto que o Estado atua minimamente ao funcionar como árbitro no cenário econômico, sendo esse marcado por ampla concorrência [...]" (Batista, 2012, p. 178). Logo, essa forma de Estado, pautado pela priorização da liberdade econômica individual traz consigo o liberalismo, e ainda o neoliberalismo econômico e político para as governanças sob seu domínio, transformando o Estado-polícia de outrora em Estado de serviço, que se utiliza de seu aparelhamento coercitivo para manter a ordem social frente à desigualdade econômica que germina neste contexto.

Todavia, para que estas concepções de Estado sejam compreendidas em sua totalidade há de se relevar seu embrião, seu surgimento e contexto histórico, que possuem fundamental importância no processo de consolidação estrutural do Estado e sua relação com as políticas públicas e a ausência delas, em toda a sua variação de poder, alienação e fúria, que ora estende as mãos aos pobres, ora os produz, ora concilia este ínterim.

Mas afinal, como nasceu tamanho domínio, e suas mais sistemáticas nuances?

Andrada (2012, p. 166) parte do conceito de que “[...] o Estado é filho de uma evolução que busca suas raízes em entidades históricas, como impérios, reinos, feudos e tribos de toda espécie de conglomerado ou grupo que cria formas de dominação, meios conhecidos como expressão de poder." Para, assim, discorrer sobre o processo histórico que precisa ser reconhecido como precursor de fundamentais ao avanço do mundo; as relações entre os Estados, as implementações de políticas públicas, o desenvolvimento da consciência política entre os povos- responsável pelas implementações das políticas sociais- mas que pos- 
suem total controle sobre o comportamento humano, devido a suas relações de base: Executivo, Legislativo e Judiciário, que mesmo em diferentes configurações e maturidade, ainda respaldam as variadas formas de Estado ao redor do mundo.

Neste ínterim,já em 1884, Engels, a partir das investigações de Morgan ${ }^{3}$ trouxe elementos históricos primordiais pra o esclarecimento do surgimento do Estado, sua relação com a instituição familiar e a intrínseca necessidade transformadora de proteção à propriedade privada. Assim, os processos expansionistas humanos, suas criações constante de necessidades e transformação material, sobretudo, da natureza por meio das relações de trabalho, deram o norte para a consolidação dos eminentes olhos que tudo veem:

[...] a acumulação, portanto, cada vez mais acelerada, das riquezas -; uma instituição que, em uma palavra, não só perpetuasse a nascente divisão da sociedade em classes, mas também o direito de a classe possuidora explorar a não-possuidora e o domínio da primeira sobre a segunda. E essa instituição nasceu. Inventou-se o Estado (Engels, 1984, p. 120, grifo no original).

Para além de uma nova estrutura familiar, que outrora consistia em comunidades gentílicas ${ }^{4}$ - Gens - de direitos e deveres predominantemente equivalentes conforme as divisões de trabalho; o surgimento do Estado consolidou a desigualdade econômica e social a tal sorte que as $\mathrm{Gens}$ passaram a explorarem-se conforme o acúmulo de propriedades e, consequentemente, relações de poder, numa ruptura com antiga comunidade de direitos equivalentes e leis próprias conforme o consenso de seus integrantes, assim “[...] o primeiro sintoma de formação do Estado consiste na destruição dos laços gentílicos, dividindo os membros de cada gens em privilegiados e não privilegiados, e dividindo estes últimos em duas classes, segundo seus ofícios, e opondo-as uma à outra" (Engels, 1984, p. 122).

${ }^{3}$ Ver: ENGELS, Friedrich. A origem da família, da propriedade privada e do Estado. 9. ed. Rio de Janeiro: Civilização Brasileira, 1984.

${ }^{4}$ Segundo Engels (1984) a partir dos estudos de Morgan, tratava-se de comunidades que trataram da divisão do trabalho, renda, consumo, propriedade, direito materno e paterno, assim como o matrimônio de forma primitiva, mas que evoluiu ao longo do tempo inaugurando assim, uma nova sociedade por classes, a sociedade moderna. 
A partir da ruptura das comunidades gentílicas, para a sociedade de classes, uma nova necessidade passa a ser criada: a segurança das propriedades, rebanhos e materiais individuais. Neste contexto, o Estado, nascido para gerir o acúmulo de riquezas, passa a estruturar-se para que os novos direitos a partir de novas necessidades se estabeleçam ou pelo consenso e alienação, ou pela força. E assim se constituiu mais uma parte primordial do Estado: a polícia e as organizações militares, para valer-se coercitivamente de seus interesses.

Com um Estado crescente, novos interesses e constituição familiar -família monogâmica- a sociedade, agora dividida em classes e subdivisões acirradas de trabalho, passa a organizar-se como tal e a requerer seus interesses de classes. Assim, instituições públicas foram criadas para assegurar tais interesses "os novos grupos, formados pela divisão do trabalho (primeiro entre a cidade e o campo, depois entre os diferentes ramos de trabalho nas cidades), haviam criado novos órgãos para a defesa dos seus interesses, e foram instituídos ofícios públicos de todas as espécies” (Engels, 1984, p. 126). Materializando-se a intrínseca relação entre Estado e políticas públicas para atendimento das demandas sociais em suas variadas instâncias.

\section{As políticas educacionais na tessitura do estado e das políticas públicas sociais}

Qual o lugar das políticas educacionais dentro do Estado? Como são implementadas pelas políticas sociais? Questionamentos básicos que possibilitam um norte para desnudar este tema tão importante quanto descurado no Brasil. As relações de poder cada vez mais hegemônicas revelam as entranhas dos interesses oclusos, bem como o valor político, midiático, sobretudo econômico que se instaura no contexto das políticas públicas educacionais. Fato que pode ser vislumbrado pelos próprios índices governamentais, e que se configura irrefutável à luz da história.

A elaboração das propostas políticas educacionais revela a forma como o Estado está estruturado, e assim sua intencionalidade com cada ação, e até mesmo a falta de ação defronte a determinadas demandas, isso porque para Secchi (2013, p. 107) “[...] a elaboração de uma política pública pode ser conduzida, por exemplo, de forma mais autocrática ou mais democrática; ou com o 
predomínio de mecanismos de premiação ou de coação". O que remete ao peso das ações do Estado neste contexto e seu papel central na tomada de decisões e deliberações das políticas sociais, assim, educacionais, e sua íntima relação de poder com territórios outros, a exemplo do Banco Mundial, grande financiador das políticas educacionais brasileiras, intensificadas desde MEC-USAID 5 .

Fica assim evidente a materialização do Estado com a implementação das políticas educacionais, num contexto de interesses que muitas vezes ultrapassa as fronteiras da pátria, ao que Azevedo (2004) trata com êxito por meio de uma análise sistemática, subsidiada por “[...] estudos que se utilizam de ferramentas dos paradigmas clássicos são facilmente agrupados e identificados: liberais, marxistas, funcionalistas" (Azevedo, 2004, p. 7) doando discernimento para esta rede de conexões que resultam na inferência direta das políticas econômicas, sociais e educacionais, ou seja, em toda a estrutura que rege os direitos dos cidadãos.

Ao discorrer por uma abordagem neoliberal das políticas públicas, a autora salienta que Defensores do Estado Mínimo, os neoliberais creditam ao mercado a capacidade de regulação do capital e do trabalho e consideram as políticas públicas as principais responsáveis pela crise que perpassa as sociedades" (Azevedo, 2004, p. 12) o que dá o tom do contexto em que se encontram as medidas sociais regidas pelo Estado neoliberal, e ainda, no que tange à educação completa:

Coerentemente com as idéias liberais, a abordagem neoliberal não questiona a responsabilidade do governo em garantir o acesso de todos ao nível básico de ensino [...] Postula-se que os poderes públicos devem transferir ou dividir suas responsabilidades administrativas com o setor privado [...] (Azevedo, 2004, p. 15).

A priori, a garantia do acesso à educação por todos parece uma contradição ao Estado Liberal, já que considera as políticas públicas uma mazela social, porém, é possível vislumbrar por entre as relações históricas, que ao remeter-se

5 Acordos firmados na década de 1960, entre o Ministério da Educação brasileiro (MEC) e a United States Agency for International Development (USAID). Objetivavam relações de orientação técnica e cooperação financeira à educação brasileira. Período em que se instaurou a ditadura militar no país. 
a uma educação básica o liberalismo se refere a uma educação utilitarista, necessária para uma instrução básica aos trabalhadores das fábricas, indústrias e comércios, ou seja, nada que mude o status quo das classes trabalhadoras, e pelo contrário, que sirvam para manter o sistema capitalista vigente, a tal ponto que a educação além do nível básico é ofertada a classe trabalhadora em modalidades técnicas, e mesmo os cursos superiores são restritos o acesso, numa divisão implícita dos cursos aos filhos do proletariado e aos filhos da burguesia, numa ciclo interminável de manutenção das classes e dos interesses do mercado.

Neste contexto, as políticas públicas para a educação fazem parte de políticas de governo que conversam com todo tipo de interesse capitalista, mudando suas prioridades conforme as eleições em propostas de programas passageiros, que são planejados, implementados e avaliados pelo viés do Estado vigente, perpetuando um sistema educacional instável e ineficiente que não possui forças para se desvencilhar, e passa a reproduzir as teorias e práticas de interesse político de cada governo, ao que Saviani (1993, p. 27) acrescenta: "[...] todas as reformas escolares fracassaram, tornando cada vez mais evidente o papel que a escola desempenha: reproduzir a sociedade de classes e reforçar o modo de produção capitalista." Evidenciando os modos de governar e os tipos de interesse econômicos em foco.

Assim, fadando o sistema educacional ao fosso do fracasso e da desigualdade, tanto do acesso, quanto da permanência, mesmo que propagado como universal, o que "Do ponto de vista da burguesia, cujos interesses estão ligados à manutenção da hegemonia e ampliação dos lucros, a escola cumpre a tarefa de disseminar os valores necessários à manutenção da ordem, bem como a função de qualificar [...] pero no mucho [...]" (Santos Junior, 2018, p. 57, grifos do autor) o que produz as marcas de uma dinastia proletária: mãos para o trabalho esforçado e vencido.

Quanto à concepção da teoria liberal moderna da cidadania, a autora pondera diferentes abordagens para tecer uma análise conceitual referente ao tema, atentando-se para suas raízes nas contribuições de Durkheim, afirmando que "Neste autor encontra-se, pela primeira vez, uma formulação mais precisa sobre a educação como uma política pública [...]” (Azevedo, 2004, p. 24). 
Assim ao trazer a abordagem pluralista e a abordagem social democrata, é possível compreender suas principais divergências no que tange o papel social nas decisões das decisões políticas dentro do Estado, sendo a primeira abordagem contrária à participação efetiva devido acreditarem na falta de preparo da grande maioria da população.

Já a segunda abordagem considera os movimentos sociais de suma importância para a tomada de decisões políticas, todavia Azevedo (2004, p. 21) é enfática ao afirmar que "não se pode desconhecer que tanto o neoliberalismo quanto o funcionalismo e a própria teoria liberal moderna da cidadania têm suas raízes no liberalismo clássico e situam-se como construtos teóricos voltados para a preservação daquela ordem" devido não enfrentarem a divisão de classes e seus pressupostos sociais e educacionais exploratórios, consequência da manutenção do sistema capitalista hegemônico e do Estado liberal.

Ao discorrer sobre a abordagem marxista é deixado claro a preocupação deste enfoque em encontrar meios para que o ser humano possa ter maiores condições de igualdade e bem-estar, excluindo de sua conjuntura a possibilidade da divisão de classes, própria das relações capitalistas do Estado liberal, pois "afinal, uma das maiores contribuições de Marx foi mostrar as raízes das desigualdades e da exploração inerentes às sociedades de classes. Foi por esta ótica, pois, que abordou as políticas sociais, de resto, quase inexistentes no seu tempo" (Azevedo, 2004, p. 39) sendo um dos precursores das discussões relacionadas às condições materiais de sobrevivência desvinculada a organização social de classes.

Este viés teórico e analítico esclarece o quanto à abordagem do Estado para com as políticas públicas educacionais perpassam por prioridades econômicas e suas relações de poder, revelando a intrínseca ligação destas políticas em propagar os referenciais das bases ideológicas de cada governo e garantir a permanência destes em suas bases de governança, ao que Santos Junior (2018) corrobora:

Reconhecemos a impossibilidade de se investigar criticamente a função social da escola sem considerar a crise mais geral do modo de produção capitalista. É no marco desta crise que se desenvolve o projeto de mundialização 
da educação, impregnada do viés privatista da empregabilidade, de um lado, e a proposição de formação humana na perspectiva do desenvolvimento omnilateral, do outro. (Santos Junior, 2018, p. 50).

Neste percalço, a implementação das políticas educacionais, quer por meio de programas, quer por projetos e pactos em períodos pré-estabelecidos, requerem, diante a atual conjuntura, um objetivo político claro que corresponda aos interesses governamentais, o que inclui os programas de formação docente, ampliados no Brasil na década de $1990^{6}$ com o advento de cobranças de organismos internacionais - Banco Mundial - para resultados melhores quanto aos índices educacionais brasileiros, sobretudo, quanto à taxa de analfabetismo indigna do país, que, embora tenha diminuído paulatinamente, ainda permite um grande percentual às margens da escolarização, conforme tabela.

Tabela 1 - Analfabetismo na faixa de 15 anos ou mais no Brasil- 1900/2000.

\begin{tabular}{r|rrr}
\hline \multirow{2}{*}{ Ano } & \multicolumn{3}{|c}{ População de 15 anos ou mais } \\
\cline { 2 - 4 } & \multicolumn{1}{|c|}{ Total $^{(1)}$} & Analfabeta $^{(1)}$ & $\begin{array}{c}\text { Taxa de } \\
\text { Analfabetismo }\end{array}$ \\
\hline 1900 & 9.728 & 6.348 & 65,3 \\
1920 & 17.564 & 11.409 & 65,0 \\
1940 & 23.648 & 13.269 & 56,1 \\
1950 & 30.188 & 15.272 & 50,6 \\
1960 & 40.233 & 15.964 & 39,7 \\
1970 & 53.633 & 18.100 & 33,7 \\
1980 & 74.600 & 19.356 & 25,9 \\
1991 & 94.891 & 18.682 & 19,7 \\
2000 & 119.533 & 16.295 & 13.6
\end{tabular}

Fonte: INEP, 2018, adaptado por Matias (2018).

Atualmente a taxa de analfabetismo entre brasileiros entre 15 anos ou mais, foi estimada, pelo último censo do IBGE (2014) em 8,3\%, uma taxa que aparenta uma queda no analfabetismo, contudo, corresponde a 11,8 milhões de brasileiros analfabetos (Brasil, 2018).

6 Com a "Declaração Mundial sobre Educação para Todos". Documento derivado da Conferência de Jomtien, Tailândia. 
Neste ínterim, propostas periódicas de formação docente ganharam maior expansão no país, exemplo do recente programa: Pacto Nacional pela Alfabetização na Idade Certa (PNAIC), que iniciou como um programa local no estado do Ceará em 2007, e em 2014 foi implementado em todo o país, a fim de garantir que todas as crianças sejam alfabetizadas, impreterivelmente, até os oito anos de idade. Entendê-lo é entender também a forma atual do Estado brasileiro pensar as políticas educacionais recentes, e assim vislumbrar possibilidades de transformação neste campo conflituoso.

\section{A implementação do Pacto Nacional pela Alfabetização na Idade Certa}

Para melhor compreensão acerca da implementação do Pacto Nacional pela Alfabetização na Idade Certa - PNAIC - buscou-se dados em sites oficiais, bem como pesquisas recentes junto a BDTD - Biblioteca digital de teses e dissertações a exemplo do Periódico CAPES, que versam sobre o tema e trazem pontos de vista substanciais à tessitura desta análise do pacto, que faz parte de uma política educacional recente para formação de professores no Brasil, e fonte de interesse para quem busca o desnudamento do atual cenário político e educacional brasileiro.

Com objetivo claro de elevar os índices educacionais no que tange a alfabetização no Brasil:

O PNAIC - Pacto Nacional pela Alfabetização na Idade Certa1 é um compromisso formal e solidário assumido pelos governos Federal, do Distrito Federal, dos Estados e dos Municípios, desde 2012, para atender à Meta 5 do Plano Nacional da Educação (PNE), que estabelece a obrigatoriedade de alfabetizar todas as crianças, no máximo, até o final do $3^{\circ}$ (terceiro) ano do ensino fundamental (BrasiL, 2017, p. 3).

O PNAIC surgiu como uma expansão do Pacto pela Alfabetização na Idade Certa- PAIC- implementado no estado do Ceará pela Lei nº14.026, de 17 de dezembro de 2007 que obteve resultados educacionais satisfatórios atribuídos à formação, gerando o interesse do Ministério da Educação em expandi-lo ao restante do país. 
A proposta de formação continuada foi lançada pelo Governo Federal no ano de 2012 por meio da Port. no 867 em 4 de julho com as seguintes finalidades:

Art. $1^{\circ}$ - Fica instituído o Pacto Nacional pela Alfabetização na Idade Certa, pelo qual o Ministério da Educação (MEC) e as secretarias estaduais, distrital e municipais de educação reafirmam e ampliam o compromisso previsto no Decreto ${ }^{\circ} 6.094$, de 24 de abril de 2007, de alfabetizar as crianças até, no máximo, os oito anos de idade, ao final do $3^{\circ}$ ano do ensino fundamental, aferindo os resultados por exame periódico específico, que passa a abranger:

I - a alfabetização em língua portuguesa e em matemática;

II - a realização de avaliações anuais universais, pelo Instituto Nacional de Estudos e Pesquisas Educacionais Anísio Teixeira - Inep, para os concluintes do $3^{\circ}$ ano do ensino fundamental;

III - o apoio gerencial dos estados, aos municípios que tenham aderido às ações do Pacto, para sua efetiva implementação (Brasil, 2012, p.1).

Com objetivos claros e incumbências definidas para cada instância gerencial - Estados, Municípios e Distrito Federal - o pacto trouxe inicialmente definições para uma formação aos professores dos primeiros anos da alfabetização, ou seja, $1^{\circ}, 2^{\circ}$ e $3^{\circ}$ anos do Ensino Fundamental em que as crianças de até oito anos precisam, impreterivelmente, estar alfabetizadas, conforme orientações do pacto.

Segundo o documento orientador das ações para formação continuada do pacto (Brasil, 2017) em 2013, foram capacitados em Linguagem, 313.599 professores-alfabetizadores, com carga horária de 120 horas; em 2014, foram 311.916 profissionais com ênfase da formação Matemática, com carga horária de 160 horas; em 2015, foram capacitados 302.057 professores em Gestão Escolar, Currículo, A Criança do Ciclo de Alfabetização e Interdisciplinaridade e em 2016 foram 248.919 alfabetizadores e 38.598 coordenadores pedagógicos, atendidos em cursos com carga horária mínima de 100 horas e com ênfase em leitura, escrita e letramento matemático. 
Todos os envolvidos no pacto ganham bolsas de incentivo pelo Governo Federal, vinculadas à avaliação e frequência do cursista, sendo os valores conforme descritos abaixo.

Quadro 1 - Valores das bolsas pagas pelo Governo Federal aos envolvidos no Pacto.

\begin{tabular}{|l|c|}
\hline Função & Valor(R\$) \\
\hline Professor Alfabetizador & 200,00 \\
\hline Orientador de estudo & 765,00 \\
\hline Coordenador das ações do pacto nos estados, Distrito Federal e municípios & 765,00 \\
\hline Formador da instituição de ensino superior & $1.100,00$ \\
\hline Supervisor da instituição de ensino superior & $1.200,00$ \\
\hline Coordenador adjunto da instituição de ensino superior & $1.400,00$ \\
\hline Coordenador-geral da instituição de ensino superior & $2.000,00$ \\
\hline
\end{tabular}

Fonte: FNDE, 2018, organização por Matias (2018).

Deste modo, as formações do pacto ocorreram em diferentes horários em todo o Brasil, sempre em contra turno de trabalho dos professores alfabetizadores, assim, as formações chegaram a acontecer em períodos noturnos e até finais de semana, numa carga horária máxima de 12 horas semanais.

As instituições formadoras ficaram a critério da possibilidade da oferta em cada localidade, visto as exigências do MEC, conforme documento orientador do PNAIC, 2017:

As instituições formadoras devem ser escolhidas por sua experiência no PNAIC, elevada competência profissional e capacidade de inovar e empreender. Elaborarão projetos pedagógicos de formação em serviço marcados pela integração entre teoria e prática, criatividade, flexibilidade e resolução de problemas detectados na rede onde atuam. Tecnologias educacionais e metodologias ativas deverão compor o conjunto de métodos, técnicas e recursos adotado nos projetos de formação (Brasil, 2017, p. 14). 
Nos anos de 2013 a 2016 foram encaminhados aos formandos materiais didáticos sobre cada área de conhecimento trabalhada - Linguagem, Matemática, Ciências da Natureza, Temas transversais e sobre as Avaliações Externaseram cadernos com textos de apoio aos conteúdos e sugestões de atividades aos professores alfabetizadores, que posteriormente eram socializadas pelos grupos de estudo.

Imagem 1 - Cadernos de estudo disponibilizados pelo MEC para formação do PNAIC.

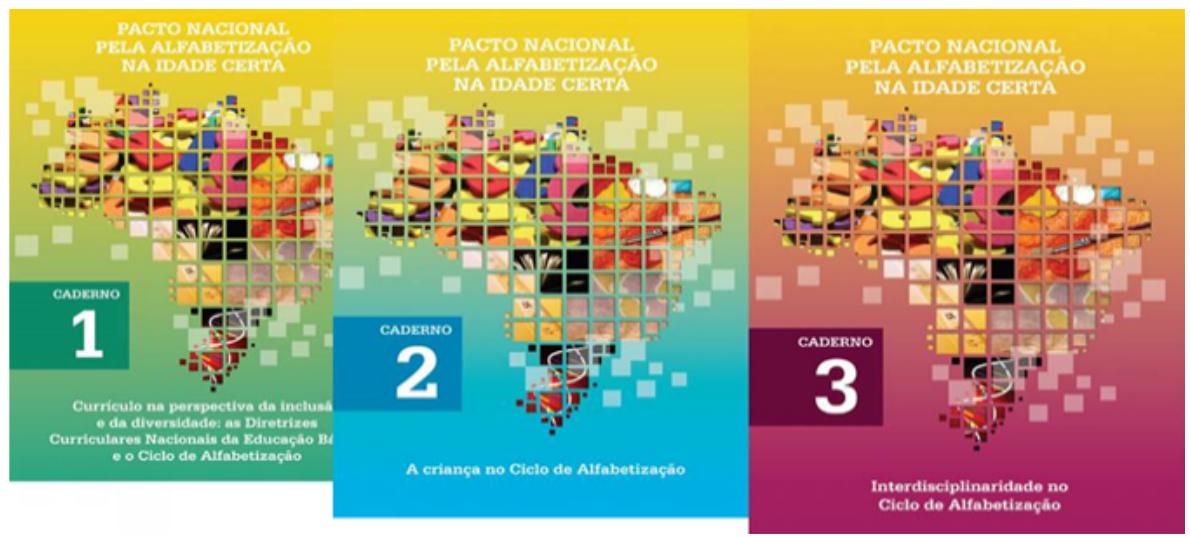

Fonte: UFC, 2018, organização por Matias (2018).

Também fizeram parte dos materiais encaminhados pelo MEC aos Estados e Municípios livros de Literatura Infantil e jogos para alfabetização. Este material foi disponibilizado para uso do aluno, sob a orientação do professor alfabetizador nas escolas. 
Imagem 2 - Jogos encaminhados para as escolas pelo MEC.

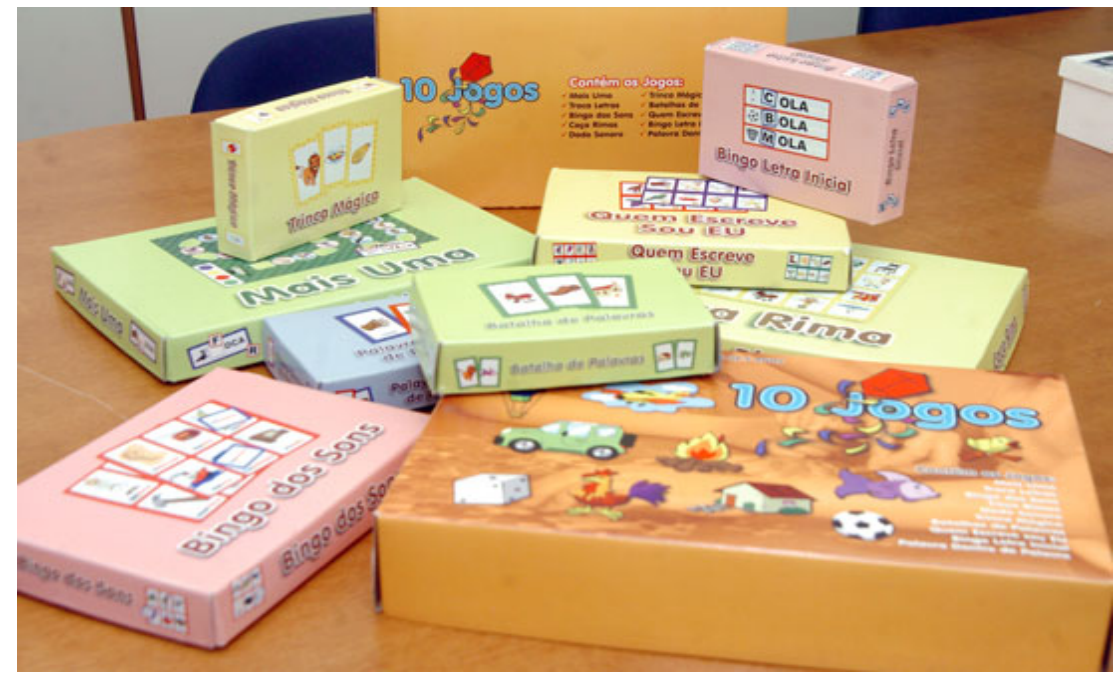

Fonte: UFC, 2018, organização por Matias (2018).

Imagem 3 - Livros de literatura infantil encaminhados para as escolas pelo MEC.

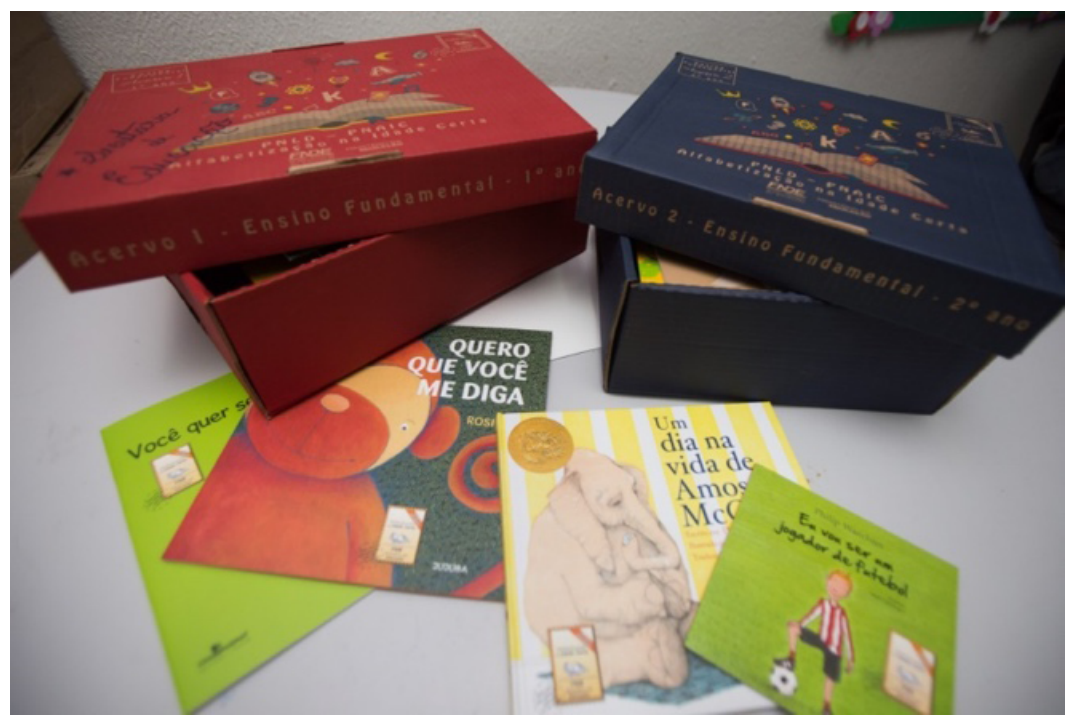

Fonte: UFC, 2018, organização por Matias (2018).

Quanto à avaliação dos professores participantes do pacto "Caberá ao Comitê Gestor definir o processo de avaliação do desempenho dos cursistas, especificando os princípios e os instrumentos que orientarão esse processo [...] 
atendendo aos critérios de desempenho estabelecidos e ao critério de no mínimo 75\% de frequência conforme previsto na legislação" (Brasil, 2017, p. 23).

Para o ano de 2018, diante da nova conjuntura política brasileira, foi proposto pelo MEC uma mudança na estrutura organizacional do programa. Além da oferta dos cursos a professores alfabetizadores, foi abrangido também a Educação Infantil e a Educação em tempo Integral: o Programa Novo Mais Educação - PNME - assim, professores da educação infantil, ensino fundamental I e ensino fundamental II podem participar do pacto, porém desde o ano de 2017 os materiais disponibilizados são, em sua maioria, digitais como versa o documento norteador das ações do pacto sobre a Educação Infantil (BRASIL, 2017, p.18) “[...] o material 'Leitura e Escrita na Educação Infantil' será disponibilizado pelo MEC em formato digital, para dar suporte ao processo de formação do PNAIC na Educação Infantil”. O material foi/é produzido pela Universidade de Minas Gerais - UFMG.

Sobre o Programa Novo Mais Educação “[...] o material para a formação será apresentado em formato digital e prevê a superação dos desafios apontados pela avaliação diagnóstica das turmas em Língua Portuguesa e Matemática" (Brasil, 2017, p. 19). E ainda, sobre material do $1^{\circ}$ ao $3^{\circ}$ ano:

Uma mudança implantada no PNAIC 2017 é a assistência financeira aos estados para a impressão de material de formação e apoio à prática docente, com foco na aprendizagem do aluno da educação básica, que será adotado pelos estados, munícipios e Distrito Federal, conforme trata o art. $1^{\circ}$ da Resolução CD/FNDE n ${ }^{\circ} 10$, de 4 de dezembro 2015. Para receber a assistência financeira de que trata a Resolução CD/FNDE $n^{\circ}$ 10/2015, a rede interessada, por meio do respectivo estado, deverá preencher os requisitos e exigências estabelecidos na Portaria MEC n² 279, de 6 de março de 2017 (Brasil, 2017, p.19).

Assim como especificado no ano de 2017, em 2018 persiste a mesma norma para a disponibilidade e acesso aos materiais de formação, sendo a grande maioria digitalizada. As ações do pacto de 2018 são regidas pelo documento norteador de 2017: Portaria MEC n 851, de 13 de julho de 2017. 


\section{Considerações}

A maneira como as políticas públicas são pensadas e implementadas pelo Estado sofreu, historicamente, transformações e, embora ainda tenha em sua totalidade o atendimento a demandas sociais, a forma como esta política acontece, os fins de cada uma, bem como seus atores, já não são ponderados como no princípio, conforme enunciado por Engels em 1884.

A consolidação do capitalismo, as revoluções, o avanço da industrialização dos meios de produção em toda a sua recente tecnologia, e também as grandes guerras, contribuíram para que as políticas públicas se reestruturassem a atender em parte as demandas sociais, e prioritariamente manter os interesses do mercado, pois “[...] dependendo do tipo de política pública que está em jogo, à estruturação dos conflitos, das coalizões e o equilíbrio de poder se modificam" (Secchi, 2013, p. 16), assim como em um jogo de cartas marcadas, as políticas públicas se tornaram valiosas e passíveis de serem implementadas conforme o Estado e as políticas vigentes, ou a falta delas.

Levar em conta o contexto histórico em que se é implementada uma política social é primordial para que não se caia no conto da bondade ilusória, pois “[...] através dessas medidas, o Estado e os políticos aparecem como bons para o povo, preocupados com sua situação social [...]” (Faleiros, 2006, p. 12) o que, à luz da história, não se mostra uma realidade.

Neste ínterim é evidenciada a relação do estado e as políticas sociais, assim, educacionais, e como esta afinidade define as propostas para educação no Brasil: de programa em programa, de governo em governo, sem garantia de continuidade ou mudança. Nesta conjuntura, a implementação do PNAIC se mostra parte de um sistema historicamente estabelecido e de estrutura viciada, e que espera resultados diferentes a cada reformulação da mesma formulação.

Pesquisas sobre o PNAIC muitas vezes desconsideram as relações de poder e os interesses capitalistas que envolvem os referenciais das propostas de formação, fato que gera inconsistências em suas discussões, e comprometimento de suas análises. É preciso atenção aos contextos em que as políticas educacionais são planejadas e implementadas, em muitos casos à sorte das 
predileções do capitalismo, ao qual servem com maestria, juntando-se a teia estrutural das políticas econômicas, sociais e convenientemente, educacionais, pensadas a partir das necessidades do mercado e implementadas mediante os interesses do Estado Liberal vigente no Brasil.

\section{Referências}

ABBAGNANO, Nicola. Dicionário de filosofia. 5. ed. São Paulo: Martins Fontes, 2007.

ANDRADA, Bonifácio José Tamm de. Estado. In: CASTRO, Carmem Lúcia Freitas de; GONTIJO, Cynthia Rúbia Braga; AMABILE, Antônio Eduardo de Noronha (org.). Dicionário de políticas públicas. Barbacena: EdUEMG, 2012. p. 166-168.

AZEVEDO, Janete Maria Lins de. A Educação como política pública. 3. ed. Campinas: Autores Associados, 2004.

BATISTA, Karla da Silva Costa. Estado de direito. In: CASTRO, Carmem Lúcia Freitas de; GONTIJO, Cynthia Rúbia Braga; AMABILE, Antônio Eduardo de Noronha (org.). Dicionário de políticas públicas. Barbacena: EdUEMG, 2012. p. 169-170.

BATISTA, Karla da Silva Costa. Estado mínimo. In: CASTRO, Carmem Lúcia Freitas de; GONTIJO, Cynthia Rúbia Braga; AMABILE, Antônio Eduardo de Noronha (org.). Dicionário de políticas públicas. Barbacena: EdUEMG, 2012. p. 178-179.

BRASIL. FNDE. Resolução no 4, de 27 de fevereiro de 2013 (PANIC). Definição dos valores das bolsas e auxílios. Disponível em: https://www.in.gov.br/materia/-/asset_publisher/Kujrw0TZC2Mb/ content/id/30305399/do1-2013-03-04-resolucao-n-4-de-27-de-fevereiro-de-2013-30305391. Acesso em: 18 de Jul. 2019. 
BRASIL. Ministério da Educação. Taxa de analfabetismo no Brasil. Disponível em: http://portal.mec.gov.br/component/tags/tag/34167. Acesso em: 16 de Jul. 2019.

BRASIL. Ministério da Educação. Documento orientador 2017 (PNAIC). Disponível em: http://pacto.mec.gov.br/images/pdf/doc_orientador/doc_ orientador_versao_final.pdf.Acesso em: 14 de Jul. 2019.

BRASIL. Secretaria de Estado de Educação-DF. Pacto Nacional pela Alfabetização na Idade Certa. Disponível em: http://www.se.df.gov.br/pnaic-pacto-nacional-pela-alfabetizacao-na-idade-certa/. Acesso em: 16 de Jul. 2019.

ENGELS, Friederich. A origem da família, da propriedade privada e do Estado. 9. ed. Rio de Janeiro: Civilização Brasileira, 1984.

FALEIROS, Vicente de Paula. O que é política social. São Paulo: Brasiliense, 2006.

LOMBARDI, José C. Pedagogia histórico-crítica: desafios para sua implementação. PASQUALINE, Juliana, C. TEIXEIRA, André, L. AGUDO, Marcela, M. (orgs.). Pedagogia histórico-crítica: legado e perspectivas. Uberlândia: Navegando, 2018.

MATIAS, Juliana Cândido; NUNES, Márcia Jovani de Oliveira; SILVA, Andressa Lima da; BARROS, Josemir Almeida. Perspectivas metodológicas e os bordados na pesquisa qualitativa em educação. EDUCA - Revista Multidisciplinar em Educação, Porto Velho, v. 6, n. 13, p.128-145, 30 mar. 2019. DOI: http://dx.doi.org/10.26568/2359-2087.2019.3721. Disponível em: http:// www.periodicos.unir.br/index.php/EDUCA/article/view/3721. Acesso em: 20 de março de 2021.

OLIVEIRA, Cristiano, José. Formação continuada no Pacto Nacional pela Alfabetização na Idade Certa - PNAIC: percepção dos professores participantes. Universidade do Vale do Sapucaí, Programa de Pós Graduação em 
Educação. 06/06/2017. 112f. Dissertação (Mestrado). Pouso Alegre (MG), 06 de Junho de 2017. Disponível em: http://www.univas.edu.br/me/docs/dissertacoes2/70.pdf. Acesso em: 11 de Jul. 2019.

PIRES, Maria Coeli Simões; COSTA, Mila Batista Leite Corrêa da. Estado democrático. In: CASTRO, CARMEM Lúcia Freitas de; GONTIJO, Cynthia Rúbia Braga; AMABILE, NORONHA, Antônio Eduardo de. (org.). Dicionário de políticas públicas. Barbacena: EdUEMG, 2012. p. 171-172.

SANTOS JUNIOR, Cláudio, de L. A pedagogia histórico-crítica e o papel da escola e do professor: elementos para pensar a escola da transição. In: PASQUALINE, Juliana, C. TEIXEIRA, André, L. AGUDO, Marcela, M. (Orgs.). Pedagogia histórico-crítica: legado e Perspectivas. Uberlândia: Navegando, 2018.

SAVIANI, D. Escola e democracia. São Paulo: Editores associados, 1993.

SECCHI, Leonardo. Políticas públicas: conceitos, esquemas de análise, casos práticos. 2. ed. São Paulo: Cengage Learning, 2013.

\section{UNIVERSIDADE FEDERAL DO CEARÁ. UFC. Material pedagógico} do PNAIC 2015. Disponível em: http://pnaicufc.blogspot.com/2015/06/material-pedagogico-do-pnaic-2015.html. Acesso em: 18 de Jul. 2019.

VIÉDES, S. C. A. Políticas públicas em alfabetização: o Pacto Nacional Pela Alfabetização na Idade Certa no Município de Anastácio - MS. Universidade Estadual do Mato Grosso do Sul, Programa de Pós-graduação em Educação. 26/02/2015. 148f. Dissertação (Mestrado). Campo Grande (MS), 26 de fevereiro de 2015. 


\section{DIREITO À EDUCAÇÃO DE QUALIDADE NAS ESCO- LAS PÚBLICAS MUNICIPAIS EM HUMAITÁ}

Rita Diniz Barboza

Angela Maria Gonçalves de Oliveira

\section{Introdução}

Com a expansão da escolarização e com a normatização do direito à educação por meio da Constituição Federal de 1988, vários princípios constitucionais foram normatizados para a educação, conforme constam no art. 206. Dentre os princípios, destacamos o inciso que trata sobre a "garantia de padrão de qualidade" (Brasil, 1988).

O discurso sobre a qualidade na educação vem atravessando diferentes momentos na história da educação no Brasil. De acordo com Oliveira; Araújo (2005), inicialmente a qualidade da educação era vista como a oferta limitada de acesso à educação básica. Nesse sentido, quanto maior o número de matrículas, melhor era a qualidade da educação. Um segundo momento a qualidade da educação foi caracterizado pela quantidade de alunos que permaneciam e concluíam uma etapa de ensino na idade certa. Com a criação do Índice de Desenvolvimento da Educação - Ideb, criado em 2007 pelo Governo Federal para medir a qualidade de ensino fundamental no território nacional e do Exame Nacional do Ensino Médio - ENEM, a qualidade da educação é medida por meio das avaliações externas.

A oferta de Educação Básica de qualidade para todos apresenta-se, pois, como um complexo e grande desafio para o conjunto dos agentes que atuam no campo da educação, sobretudo, na implantação de políticas públicas.

O Amazonas, em se tratando de dados quantitativos, vem avançando nos últimos anos, especialmente na etapa inicial do Ensino Fundamental, cuja divulgação no último Ideb a nota se aproximou da Meta projetada. A partir da etapa final do Ensino Fundamental até o Ensino Médio, apesar de o estado 
ter atingido, na maioria dos anos as metas projetadas, os avanços estão em descompasso com o objetivo de qualidade almejado.

Para consolidação da qualidade do ensino é importante monitorar os indicadores do fluxo escolar. Dentre esses indicadores temos o modelo de gestão escolar efetivado nas escolas públicas e o fluxo escolar.

Neste artigo, analisamos os dados do índice de desenvolvimento da educação base- Ideb das escolas da Área Urbana do município de Humaitá.

Apresentamos neste trabalho os dados coletados a partir do sítio do Instituto Nacional de Estudos e Pesquisas Educacionais Anísio Teixeira Inep e analisados à luz dos teóricos que pesquisam sobre essa temática.

\section{Metodologia}

O método adotado nesta pesquisa está comprometido com uma perspectiva histórico-critica que nos possibilitou uma investigação mais aprofundada do objeto investigado, a partir de uma abordagem qualitativa, pois mesmo trabalhando com dados quantitativos, esta pesquisa teve uma abordagem qualitativa.

Como procedimentos metodológicos utilizamos a revisão bibliográfica sobre a qualidade da educação, com base em autores que estudam a referida temática. Os dados do Índice de Desenvolvimento da Educação Básica - Ideb foram coletados do sítio do Instituto Nacional de Estudos e Pesquisas Educacionais Anísio Teixeira (Inep)

\section{Qualidade da educação como direito}

A educação é uma prática social nos diversos espaços e momentos da vida que envolve os processos de desenvolvimento das capacidades e os processos de ensinar e aprender. A educação escolar, sendo objeto de políticas públicas, se destaca por seu papel formativo, para assegurar a formação e desenvolvimento físico, intelectual e moral do homem, sendo um direito de todos segundo a Constituição Federal de 1988 no seu artigo 205. "A educação, direito de todos e dever do Estado e da família, será promovida e incentivada com a colaboração 
da sociedade, visando ao pleno desenvolvimento da pessoa, seu preparo para o exercício da cidadania e sua qualificação para o trabalho" (Brasil, 1988).

No art. 206 da Carta Magna normatiza os princípios da educação pública, dentre os quais, destacamos o inciso VII - garantia de padrão de qualidade (Brasil, 1988).

Corroborando com a Constituição Federal, a Lei de Diretrizes e Bases da Educação, LDB 9394/96, no art. $3^{\circ}$ determina os onze princípios da educação pública, com destaque neste trabalho para o inciso IX - garantia de padrão de qualidade (Brasil, 1996).

Com o intuito de dá materialidade às legislações educacionais, em 2014 foi aprovado o 3o Plano Nacional de Educação por meio da Lei no 13.005 , de 25 de junho de 2014, cuja meta 7 prevê: "Fomentar a qualidade da educação básica em todas as etapas e modalidades, com melhoria do fluxo escolar e da aprendizagem de modo a atingir as seguintes médias nacionais para o Ideb” conforme podemos visualizar na tabela 1 .

Tabela 1 - Médias projetadas para o Ideb na educação básica, Brasil, 2015-2021.

\begin{tabular}{ccccc}
\hline IDEB & 2015 & 2017 & 2019 & 2021 \\
\hline Anos iniciais do ensino fundamental & 5,2 & 5,5 & 5,7 & 6,0 \\
\hline Anos finais do ensino fundamental & 4,7 & 5,0 & 5,2 & 5,5 \\
\hline Ensino médio & 4,3 & 4,7 & 5,0 & 5,2 \\
\hline
\end{tabular}

Fonte: Plano Nacional de Educação2014-2024.

Na meta 7, o PNE 2014-2024, previu 36 estratégias de modo a possibilitar seu cumprimento, tendo como principais indicadores o Ideb dos Anos Iniciais do Ensino Fundamental; o Ideb dos Anos Finais do Ensino Fundamental e o Ideb do Ensino Médio

A partir do exposto, observamos que não faltam legislações e políticas públicas em nível federal para a efetivação de uma educação de qualidade. $\mathrm{O}$ que precisa é compreender o conceito de qualidade socialmente referenciada.

O conceito de educação de qualidade modifica-se no contexto histórico. Dourado, Oliveira, Santos (2007 p. 6, grifo nosso) apontam que: 
É um fenômeno complexo que envolve múltiplas dimensões, não podendo ser apreendido apenas por um reconhecimento da variedade e das quantidades mínimas de insumos considerados indispensáveis ao desenvolvimento do processo de ensino-aprendizagem, e muito menos, pode ser apreendido sem tais insumos.

A qualidade da educação é abordada a partir de várias dimensões, dependendo da concepção de Estado e do tipo de homem que se pretende formar. Num sentido geral, qualidade tem um conceito subjetivo que está relacionada com as percepções, necessidades e resultados, geralmente é visto como algo positivo e tem relação com um bem superior, visto como virtuoso ao ser comparado com os demais, é um conceito ativo, que deve ser construído e reconstruído continuadamente.

No caso da qualidade da educação cada escola tem autonomia para refletir, indicar e atuar no caminho, e o encontro da qualidade da educação que envolve as famílias, podem exercer um papel diferenciado, que estimulando o aprendizado.

A qualidade da educação segundo Dourado; Oliveira; Santos, (2007) é definida pela relação de recursos materiais e humano, que ocorrem dentro da instituição escolar e da sala de aula. Sendo assim só tem sentido falar da educação de qualidade se considerar os conjuntos de aspectos envolvidas, onde é de fundamental importância identificar os elementos que constituem uma escola de qualidade.

A educação é o elemento que constitui as relações sociais que contribuem para a transformação dessas relações, e a educação de qualidade é o resultado de uma construção dos diversos sujeitos engajados nesse processo, como a participação ativa tanto da parte pedagógica da escola como da família, tudo isso produz um desenvolvimento positivo em relação a aprendizagem. O ambiente escolar adequado está muito relacionado ao desempenho dos estudantes, onde se destaca a formação inicial dos docentes dedicados exclusivamente a escola, e conforme o documento do Banco Mundial (Dourado; Oliveira; Santos, 2007) os materiais disponíveis a todos os alunos, recursos 
necessários disponíveis como laboratórios, equipamentos, bibliotecas, além da formação docente e de suas boas condições de trabalho, podem ser fundamental na efetivação de uma educação de qualidade.

Os estudos e análises que vem sendo realizado sobre a qualidade da educação, se dá de forma que apresentem diversos significados. Sobre o ponto de vista extraescolar implica em políticas públicas que criam programas para enfrentar questões considerando as especificidades de cada local, como combate à fome, violência, trabalho infantil entre outros, e implica também a educação democrática como direito e bem social. Por outro lado, a qualidade da educação é de fundamental importância e não deve perder a visão no que ocorre no âmbito interior da escola como avaliações, pesquisa, dinâmica, planejamento principalmente o sucesso escolar dos estudantes.

A qualidade da educação vista pela sociedade, se destaca a questão da demanda ao procurar uma "boa escola". Conforme Dourado; Oliveira; Santos (2007) a boa escola é vista pela comunidade como aquela em que tem uma visão positiva, que geram movimentos e dinâmicas de forma distinta e que oferece um ensino de qualidade.

Outra qualidade está associada as que apresentam maior caso continuidade nos estudos ou inserção no mercado de trabalho. Os Indicadores da Qualidade na Educação baseiam-se numa visão ampla de qualidade educativa e, por isso, engloba algumas dimensões como: o ambiente educativo; formação e condições de trabalho dos profissionais da escola; ambiente físico escolar; acesso e permanência dos alunos na escola; prática pedagógica e avaliação; gestão escolar democrática.

A busca da qualidade da educação também está relacionada com a formação docente e valorização do seu trabalho. Essa é uma questão que tem se tornado alvo de estudos no campo educacional, que, de modo geral é um dos grandes passos para uma escola ideal. Uma escola de qualidade é composta por profissionais de qualidade e comprometidos com a educação; educador com maior experiência e positiva que trabalha exclusivamente em uma única escola de acordo com sua formação inicial, recebendo salário digno por seu trabalho, criam condições para que a qualidade do ensino contribua para a formação con- 
tinuada. A motivação e satisfação pelo trabalho produz a educação de qualidade, pois quando o profissional se sente valorizado e incentivado, realiza com maior satisfação suas atividades. Mas também o comprometimento dos alunos e desempenho escolar não deixa de ser importante também nesse processo.

Outro fator relevante que implicada na educação de qualidade refere-se aos recursos financeiros. A Constituição Federal, no art. 212 assegura a obrigatoriedade do investimento na educação para que se torne de qualidade. A Lei de Diretrizes e Bases da Educação Nacional - LDB 9394/96, no seu artigo $4^{\circ}$, IX, "são padrões mínimos de qualidade de ensino, definidos como a variedade e quantidade mínimas, por aluno, de insumos indispensáveis ao desenvolvimento do processo de ensino-aprendizagem".

Assim também o financiamento nas instituições de ensino por cada aluno, sendo um direto de acesso de igualdade e condições para todos, conforme o artigo 206 onde tenham a liberdade de aprender, ensinar, pesquisar e divulgar com qualidade e gratuito a todo público, a infraestrutura escolar, como espaços renovados, possibilita que as crianças e jovens que vivem em locais remotos possam estudar e, além disso, tende a melhorar a assiduidade e o interesse dos estudantes e professores pelo aprendizado.

Sendo assim a educação de qualidade é um bem que busca transformar a vida das pessoas, mas só possível ter uma educação de qualidade se transformação envolver a todos no processo de ensino e aprendizagem, não podemos separar a qualidade da educação da qualidade como um todo, a qualidade na educação não pode ser boa se a qualidade do professor, do aluno, da comunidade é ruim, é preciso melhorar não só em um aspecto, mas, todo o conjunto que contribuem, dessa forma, investir em processos e estratégias que aperfeiçoem cada vez mais a metodologia de ensino é, também, uma maneira de reter e captar alunos. A boa reputação gerada pelos bons resultados da escola é fundamental para isso. E segundo leis um direito de acesso e igualdade a todos, contribuindo para a formação dos estudantes desempenhando seu papel de cidadão no mundo, pois a educação é esse instrumento de transformação para o exercício de seus direitos. 


\section{Qualidade da Educação em Humaitá: o que mostram os dados}

A partir da década de 1990, com as reformas educacionais, a qualidade da educação básica passou a ser aferida a partir da lógica de mercado. As políticas educacionais foram pensadas a partir da educação como mercadoria.

De acordo com Sousa (2014), para os formuladores de políticas educacionais, a qualidade da educação vem se constituindo a partir das avaliações em larga escala realizada pelo Sistema de Avaliação da Educação Básica (SAEB). O SAEB, foi criado pela Portaria Ministerial n. 931, de 21 de março de 2005. De acordo com o art. 1º o Sistema de Avaliação da Educação Básica - Saeb, será composto por dois processos de avaliação: a Avaliação Nacional da Educação Básica - Aneb e a Avaliação Nacional do Rendimento Escolar - Anresc [...]". O Aneb faz um levantamento amostral, de larga escala, externo aos sistemas de ensino público e particular, de periodicidade bianual, para avaliar a qualidade, a equidade e a eficiência da educação brasileira. Enquanto o Anresc, através da Prova Brasil, faz um levantamento de dados censitário para avaliar a qualidade do ensino ministrado nas escolas (Brasil, 2005).

O Saeb institui o Índice de Desenvolvimento da Educação Básica (Ideb) e foi materializado pelo Prova Brasil, para o ensino fundamental, e pelo Exame Nacional do Ensino Médio - ENEM, para o ensino médio. Este último foi criado em 1998 com o objetivo de avaliar o aprendizado dos estudantes concluintes do ensino médio.

Essas avaliações foram criadas com o objetivo de mensurar habilidades cognitivas dos estudantes em conteúdo de Língua Portuguesa e Matemática, mas também para servir como indicativos na elaboração de políticas públicas, bem como ações no âmbito da gestão escolar.

Para análise do Ideb das escolas municipais, faremos, inicialmente, a análise da rede municipal de educação e, posteriormente, faremos das maiores escolas municipais da Área Urbana de Humaitá. O gráfico 01 mostra o Ideb de toda a rede municipal de Humaitá. 
Gráfico 1 - Ideb observado no município de Humaitá - Rede Municipal - Ensino Fundamental - anos iniciais - 2007-2017.

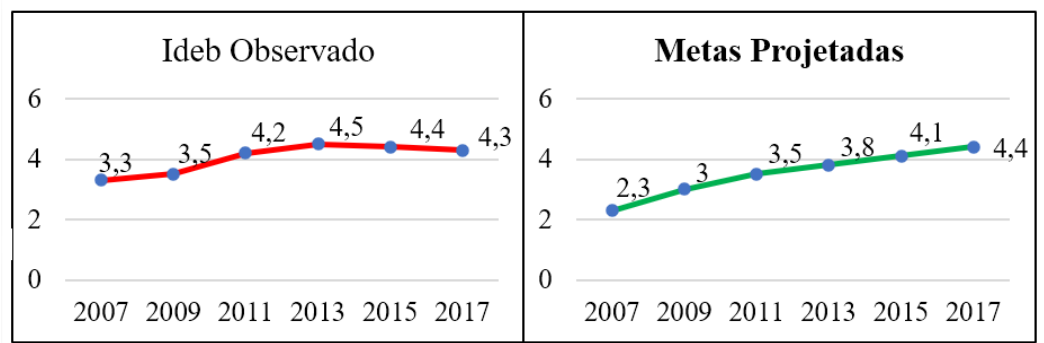

Fonte: Elaborado pela autora com base em INEP - Ideb - Resultados e Metas.

De acordo com o gráfico 1 percebemos que o Ideb da rede municipal de Humaitá, ultrapassou as metas projetas nos anos de 2007 a 2016. Contudo, houve um declínio no ano de 2017 saindo cuja meta era atingir a média de 4,4, mas ficou com 4,3. Embora sendo pequena esse declínio na média dos anos iniciais do ensino fundamental, carece de maior atenção do poder público local. Oliveira (2019, p. 174) afirma que além das médias observadas, "precisamos compreender a qualidade da educação além dos dados quantitativos. É importante analisar todo o processo educacional e em que contexto social, cultural e econômico ela ocorre". 
Tabela 2 - Ideb observado nas escolas municipais - Humaitá-AM - Ensino Fundamental Anos Iniciais - 2007-2017.

\begin{tabular}{|l|c|c|c|c|c|c|c|c|c|c|c|c|}
\hline \multirow{2}{*}{ Escola } & \multicolumn{7}{|c|}{ Média Observada } \\
\cline { 2 - 15 } & 2007 & 2009 & 2011 & 2013 & 2015 & 2017 & 2007 & 2009 & 2011 & 2013 & 2015 & 2017 \\
\hline $\begin{array}{l}\text { Escola Municipal Dom } \\
\text { Bosco }\end{array}$ & 3,7 & 2,7 & 3,6 & 3,5 & 3,8 & 4,1 & - & 3,9 & 4,2 & 4,5 & 4,8 & 5,0 \\
\hline $\begin{array}{l}\text { Escola Municipal Ed- } \\
\text { mee Monteiro Brasil }\end{array}$ & 3,1 & - & 4,4 & 4,8 & 5,3 & 4,9 & 2,5 & 3,0 & 3,5 & 3,8 & 4,1 & 4,4 \\
\hline $\begin{array}{l}\text { Escola Municipal Irma } \\
\text { Maria Carmem Cro- } \\
\text { nenbold }\end{array}$ & 3,6 & 3,4 & 4,5 & 3,9 & 4,0 & 4,5 & 2,8 & 3,1 & 3,5 & 3,8 & 4,1 & 4,4 \\
\hline $\begin{array}{l}\text { Escola Municipal Nossa } \\
\text { Senhora do Carmo }\end{array}$ & 3,6 & 4,0 & 4,6 & 4,5 & 4,4 & 4,5 & 2,9 & 3,3 & 3,7 & 4,0 & 4,3 & 4,6 \\
\hline $\begin{array}{l}\text { Escola Municipal Rosa } \\
\text { de Sarom }\end{array}$ & 4,3 & 4,8 & 4,9 & 5,8 & 5,6 & 5,3 & 3,3 & 3,6 & 4,0 & 4,3 & 4,6 & 4,9 \\
\hline $\begin{array}{l}\text { Escola Municipal Santo } \\
\text { Antônio }\end{array}$ & - & - & - & - & 4,8 & 4,0 & - & - & - & - & - & 5,0 \\
\hline $\begin{array}{l}\text { Escola Municipal São } \\
\text { Domingos Savio }\end{array}$ & - & 3,0 & - & 4,0 & 4,1 & 4,2 & - & - & 3,4 & 3,6 & 3,9 & 4,2 \\
\hline $\begin{array}{l}\text { Escola Municipal São } \\
\text { Francisco }\end{array}$ & 3,2 & 3,6 & 4,1 & 4,5 & 4,4 & 4,0 & 3,1 & 3,4 & 3,8 & 4,1 & 4,4 & 4,7 \\
\hline $\begin{array}{l}\text { Escola Municipal Vere- } \\
\text { ador Manoel de Oliveira } \\
\text { Santos }\end{array}$ & - & - & - & 2,6 & 4,0 & 3,7 & - & - & - & - & 2,8 & 3,1 \\
\hline
\end{tabular}

Fonte: Elaborado pela autora com base em INEP - Ideb - Resultados e Metas.

A tabela 2 mostra as médias observadas e metas projetadas das escolas municipais da Área Urbana de Humaitá, durante o período de 2007 a 2017. Os dados nos mostram que apenas a Escola Municipal Dom Bosco, apresentou médias inferiores às metas projetadas, conforme mostra o gráfico. As demais escolas apresentaram médias superiores às metas projetadas para o período de 2007 a 2017.

Almeida; Dalben; Freitas (2013), afirmam que tais avaliações são incipientes e não refletem a qualidade da educação brasileira, uma vez que não são considerados os muitos fatores que se encontram imbricados no processo 
educacional. Oliveira (2019) aponta que, além da média apresentada pelo Ideb, fatores como: o nível socioeconômico e cultural do alunado; a complexidade da gestão escolar; as condições de infraestrutura da escola, e insumos, e a valorização do magistério são alguns dos fatores que devem ser considerados para que se efetive uma educação de qualidade.

Em relação ao Ideb dos anos finais do ensino fundamental, o gráfico 02 mostra os dados sobre a rede municipal de Humaitá.

Gráfico 2 - Ideb observado das escolas da Área Urbana do município de Humaitá - Ensino Fundamental - anos iniciais - 2007-2017.

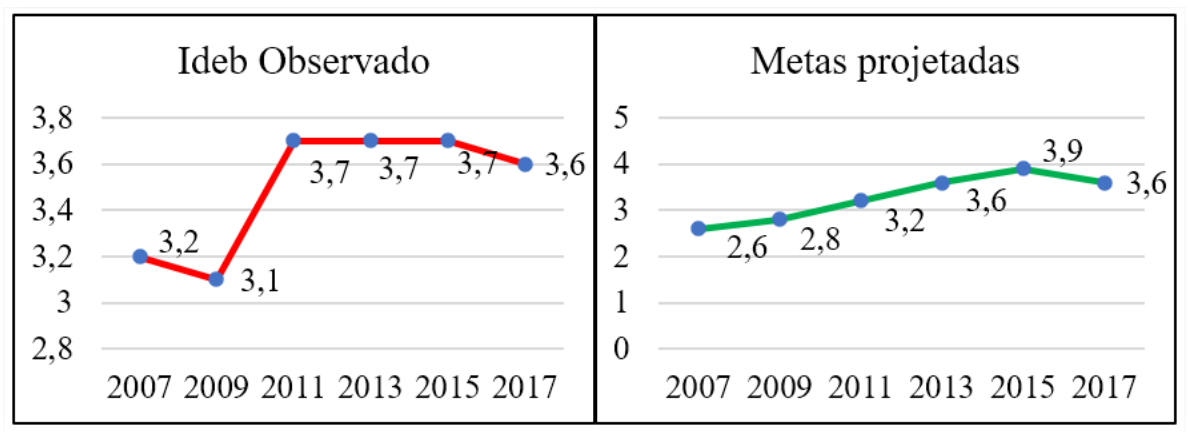

Fonte: Elaborado pela autora com base em INEP - Ideb - Resultados e Metas.

De acordo com o gráfico 02, embora com uma diferença mínima, as médias dos anos finais do ensino fundamental, foram superiores às metas projetadas para o período de 2007 a 2017.

Em relação às escolas municipais, a tabela 02 mostra as médias observadas e metas projetadas para o período de 2007 a 2017. 
Tabela 3 - Ideb observado nas escolas municipais da Área Urbana - Humaitá-AM - Ensino Fundamental - Anos finais - 2007-2017.

\begin{tabular}{|l|c|c|c|c|c|c|c|c|c|c|c|c|}
\hline \multirow{2}{*}{ Escola } & \multicolumn{5}{|c|}{ Ideb observado } & \multicolumn{7}{c|}{ Metas Projetadas } \\
\cline { 2 - 15 } & $\mathbf{2 0 0 7}$ & $\mathbf{2 0 0 9}$ & $\mathbf{2 0 1 1}$ & $\mathbf{2 0 1 3}$ & $\mathbf{2 0 1 5}$ & $\mathbf{2 0 1 7}$ & $\mathbf{2 0 0 7}$ & $\mathbf{2 0 0 9}$ & $\mathbf{2 0 1 1}$ & $\mathbf{2 0 1 3}$ & $\mathbf{2 0 1 5}$ & $\mathbf{2 0 1 7}$ \\
\hline $\begin{array}{l}\text { Escola Municipal Dom } \\
\text { Bosco }\end{array}$ & - & 2,7 & 3,4 & 3,7 & 3,6 & 3,2 & - & - & 2,9 & 3,1 & 3,4 & 3,7 \\
\hline $\begin{array}{l}\text { Escola Municipal Irma } \\
\text { Maria Carmem Cro- } \\
\text { nenbold }\end{array}$ & 3,5 & 3,4 & 3,8 & 3,8 & 4,1 & 3,9 & 2,5 & 2,6 & 2,9 & 3,2 & 3,6 & 3,9 \\
\hline $\begin{array}{l}\text { Escola Municipal José } \\
\text { Cezario Menezes de } \\
\text { Barros }\end{array}$ & - & 3,1 & 3,0 & 3,2 & 2,9 & - & - & - & 3,3 & 3,6 & 3,9 & 4,2 \\
\hline $\begin{array}{l}\text { Escola Municipal Nossa } \\
\text { Senhora do Carmo }\end{array}$ & 2,2 & - & - & - & - & - & - & 2,3 & 2,6 & 2,9 & 3,3 & 3,5 \\
\hline
\end{tabular}

Fonte: Elaborado pela autora com base em INEP - Ideb - Resultados e Metas.

De acordo com a tabela 02, a Escola Municipal Dom Bosco em 2009, obteve a média 2,7. Nesse ano não tinha meta projetada para a escola. Nos anos de 2011 a 2015, a escola apresentou Ideb superior às metas projetadas. Havendo somente no ano de 2017 uma queda, pois, a meta projetada era 3,7 e a escola atingiu a média 3,2. A escola municipal Irmã Maria Carmem Cronenbold, nos anos de 2007 a 2015, apresentou Ideb superou as metas projetadas e no ano de 2017 atingiu a meta projetada/ prevista de 3,9.

A Escola Municipal José Cesário, Meneses de Barros no ano de 2009 obteve média 3.1, nesse ano, não tinha meta projetada, de 2011 a 2015, obteve o Ideb inferior as metas projetadas e no ano de 2017 a meta projetada era de 4,2, mas não apresentou Ideb observado. A Escola Municipal Nossa Senhora do Carmo apresentou Ideb no ano de 2017 de 2,2. Nos anos de 2009 a 2017 não apresentou Ideb observado.

De acordo com os dados apresentados, as escolas municipais não apresentam grandes avanços no que diz respeito às notas do Ideb, pois mesmo a maioria das escolas ultrapassando as medias projetadas, esse aumento não 
apresenta de forma significativa. É preciso entender que a qualidade da educação está atrelada a um conjunto de fatores que tem influência direta nessa qualidade. A gestão educacional, com ênfase numa gestão democrática para a formação da autonomia do estudante.

\section{Considerações finais}

Essas avaliações, criadas a partir de princípios gerencialistas, com base em conceitos de eficiência e eficácia na educação, têm como objetivo direcionar os governos no estabelecimento de metas e ações pedagógicas para a melhoria da qualidade educacional.

Nessa concepção, a qualidade da educação foi interpretada tão somente, à luz de dados quantitativos, cujos resultados retratam o trabalho pedagógico desenvolvido na escola. Almeida; Dalben; Freitas (2013) argumentam que "os desempenhos médios obtidos não podem ser traduzidos como retrato fiel da qualidade das instituições”, sem considerar o Nível Socioeconômico (NSE) dos estudantes bem como as diferentes realidades sociais onde estão inseridos. Segundo Oliveira; Araújo (2005), o Ideb não considerou o problema das desigualdades regionais quando da aplicação das avaliações em larga escala e o direito à educação, mesmo sendo determinação constitucional, vem sendo reduzido pelas desigualdades sociais e regionais.

Para que um país tenha uma educação de qualidade é preciso ter uma política pública bem estruturada que envolva todo o ecossistema educacional. Embora já vemos uma melhora de forma sistemática no decorrer dos anos, ainda se tem um grande esforço pela frente para se alcançar uma educação de qualidade conforme as dimensões estabelecidas na constituição federal.

A qualidade da educação, vista como um bem de mercado, é direcionada pela gestão escolar que, assumiu uma postura empresarial, implicando sobremaneira nessa qualidade. A qualidade da educação, foi legitimada pelo Índice de Desenvolvimento da Educação Básica (Ideb). 


\section{Referências}

ALMEIDA, L. C.; DALBEN, A.; FREITAS, L. C. DE. O Ideb: limites e ilusões de uma política educacional. Educação \& Sociedade, v. 34, n. 125, p. 1153-1174, 2013. Disponível em: http://www.scielo.br/pdf/es/v34n125/08. pdf. Acesso em: 12 de julho 2020.

ALVES-MAZZOTTI, A. J.; GEWANDSZAJER, F. O método nas ciências naturais e sociais: pesquisa quantitativa e qualitativa. 2. ed. São Paulo: Pioneira Thomson, 2002.

BANCO MUNDIAL. Prioridades y estrategias para la educación. Examen del Banco Mundial. 1995. Disponível em: http://documents.worldbank. Acesso em: 15 de jul. 2020.

BARDIN, L. Análise de conteúdo. Lisboa: Edições 70, 2011.

BRASIL. Constituição da República Federativa do Brasil: texto constitucional promulgado em 5 de outubro de 1988. In: Brasília: Senado Federal, Coordenação de Edições Técnicas, 2016. Disponível em: https://www2.senado.leg.br/bdsf/bitstream/handle/id/518231/CF88_Livro_EC91_2016.pdf. Acesso em: 15 de jul. 2020.

BRASIL. Lei de Diretrizes e Bases da Educação Nacional - Lei 9.394/96. 1996b. Disponível em: http://www2.camara.leg.br/legin/fed/lei/1996/lei9394-20-dezembro-1996-362578-norma-pl.html. Acesso em: 15 de jul. 2020.

BRASIL. Lei N. 13005 de 2014. Plano Nacional de Educação 2014/2024. Disponível em: http://www.planalto.gov.br/ccivil_03/_ato2011-2014/2014/ lei/113005.htm . Acesso em: 14 de jun. 2018.

BRASIL. MEC/INEP/DEED/CSI. Indicadores educacionais - INEP. Disponível em: http://portal.inep.gov.br/indicadores-educacionais. Acesso em: 15 de jul. 2020. 
BRASIL. Portaria Ministerial n. 931, de 21 de março de 2005. Disponível em: http://www.stellabortoni.com.br/index.php/artigos/1115-poataaia-o-931-ii-21-03-2005-qui-iostituiu-o-saib. Acesso 10 jul 2020. Acesso em: 15 de jul. 2020.

CURY, Carlos Roberto Jamil. A qualidade da educação brasileira como direito. Educ. Soc., Campinas, v. 35, nº. 129, p. 1053-1066, out.-dez., 2014. Disponível em: https://www.scielo.br/pdf/es/v35n129/0101-7330-es-35-129-01053. pdf. Acesso em: 15 de jul. 2020.

OLIVEIRA, A. M.G de. Projeto de educação em tempo integral no estado do Amazonas e o direito à educação. 2019. Tese de doutorado. Universidade Estadual de Campinas. Disponível em: http://repositorio.unicamp.br/jspui/ handle/REPOSIP/335509. Acesso em: 15 de jul. 2020.

OLIVEIRA, Romualdo Portela de; ARAUJO, Gilda Cardoso de. Qualidade do ensino: uma nova dimensão da luta pelo direito à educação. Rev. Bras. Educ. no.28 Rio de Janeiro Jan./Apr. 2005. Disponível em: http://www.scielo.br/scielo.php?pid=S1413-24782005000100002\&script=sci_arttext. Acesso em: 15 de jul. 2020.

SOUZA, D. B. D. Avaliações finais sobre o PNE 2001-2010 e preliminares do PNE 2014-2024. Estudos em Avaliação Educacional, v. 25, n. 59, p. 104-170, 2014. Disponível em: http://publicacoes.fcc.org.br/ojs/index.php/ eae/article/view/3001. Acesso em: 15 de jul. 2020. 


\section{SOBRE OS AUTORES E AS AUTORAS}

Adão Rogério Xavier Silva Mestre em Educação (Ufac). Membro do Núcleo de Estudos e Pesquisas em Política Educacional, Gestão e Financiamento da Educação da Universidade Federal do Acre/Ufac, Campus Rio Branco/ AC. Lattes: http://lattes.cnpq.br/0972894075035313. ORCID: https://orcid. org/0000-0003-0277-3392. E-mail: adaorxs@gmail.com

André Luiz Pestana Carneiro Mestre em Educação pela Fundação Universidade Federal de Rondônia (2018/2), graduado em Direito pela Universidade Federal de Rondônia (UNIR). Atualmente membro permanente da Comissão de Heteroidentificação. Especializado em Legislação de Pessoal, Aposentadoria em Pensões e Assistência Estudantil. Tem experiência na área de Direito, com ênfase em Direito Público. Pesquisador na área de Direito e Educação; Políticas Públicas; Ações Afirmativas. Lattes: http://lattes.cnpq. br/1763039209533940. ORCID: https://orcid.org/0000-0001-6862-9487. E-mail: advandrepestana@hotmail.com

Angela Maria Gonçalves de Oliveira Doutora em Educação pela Universidade Estadual de Campinas - UNICAMP. Docente da Universidade Federal do Amazonas - Campus Humaitá-AM. Docente do Programa de Pós-Graduação em Educação da Universidade Federal de Rondônia (PPGE/UNIR). Participa do Centro Interdisciplinar de Estudos e Pesquisas em Educação e Sustentabilidade (CIEPES/UNIR) e do Grupo de Estudos e Pesquisa em Educação Infantil (GPEDIN/UFAM) Lattes: http://lattes.cnpq.br/1047034055749049. ORCID: https://orcid.org/0000-0003-1619-8958.E-mail: angela.biase@hotmail.com

Aparecida Luzia Alzira Zuin Docente do Programa de Mestrado em Educação - PPGE/UNIR. Doutora e Mestra em Comunicação e Semiótica - PUC-SP. Pesquisadora atuando, principalmente, nas seguintes áreas: Direito da Cidade (Políticas Públicas Urbanas; Cidades Educadoras e Sustentáveis); Comunicação e Direito Alimentar (comunicação socioambiental; alimento como 
direito humano; sociedade do risco; produção, consumo e mercado); Comunicação e Semiótica (Cultura Contemporânea; Semiótica Jurídica; Mídia, Redes Sociais, Política, Democracia e Tecnologias emergentes (esfera pública e esfera privada na Internet)); Educação, Direito e Política (Gestão, Estado e Ações Afirmativas para negros, indígenas e população de baixa renda na Amazônia Ocidental). Lattes: http://lattes.cnpq.br/1584841068017210. ORCID: http://orcid.org/0000-0002-5838-2123. E-mail: alazuin@gmail.com

Berenice Perpetua Simão Professora na rede pública de ensino, Doutoranda em Educação Profissional (PPGE) e Mestra em Desenvolvimento Regional e Meio Ambiente (PGDRA) pela Universidade Federal de Rondônia/UNIR. Graduada em Letras e Educação Física, Especialista em Literatura Brasileira e Gestão de Sistemas Complexos na Amazônia. É também Membro dos Grupos de Pesquisas GPERS - Grupo de Pesquisa em Energia Renovável Sustentável (UNIR) e Amazon Dams Network (UF/EUA). Lattes: http:// lattes.cnpq.br/4415520771247535. ORCID: https://orcid.org/0000-00026938-5346. E-mail: bereniceperpetua@gmail.com

Célio José Borges Professor Associado IV do Departamento de Educação Física da Universidade Federal de Rondônia - Doutor em Educação Escolar Política e Gestão Educacional, atuando na graduação nos cursos de Educação Física e Pedagogia e no Programa de pós-graduação em Educação - Mestrado Acadêmico em Educação - PPGE/UNIR. Membro dos grupos de Pesquisa do Desenvolvimento e da Cultura Corporal (vice líder) e Líder do grupo de pesquisa - Centro de Estudo e Pesquisa do Humanismo Ikeda. Lattes: http:// lattes.cnpq.br/8265409596842772. ORCID: https://orcid.org/0000-00024385-6234. E-mail: ceborges@gmail.com

Clarides Henrich de Barba Possui Licenciatura em Filosofia pela Pontifícia Universidade Católica do Paraná (1982), Licenciatura em Educação Física pela Universidade Federal de Rondônia (1989), Mestrado em Filosofia pela Universidade Federal de Santa Maria (1996). Doutor em Educação Escolar pela Universidade Estadual Paulista Júlio de Mesquita Filho (2011). Atualmente é Professor Associado IV da Universidade Federal de Rondônia. É pesquisador 
em Educação Ambiental, Ética e cultura amazônica em Educação Ambiental, Políticas Públicas em Educação Escolar e em Educação Ambiental. Orienta pesquisas em Educação Ambiental e Ambientalização Curricular. É líder do Grupo de Pesquisa Interdisciplinar em Educação Ambiental no contexto amazônico. Também faz parte do Grupo de Pesquisa CIEPES (Centro Interdisciplinar de Estudos e Pesquisas em Educação e Sustentabilidade, localizado na Universidade Federal de Rondônia. Lattes: http://lattes.cnpq.br/4572407003327880. ORCID: https://orcid.org/0000-0002-5658-4485.E-mail: clarides@unir.br

Divina Rogéria Corrêa Santos Licenciada em Pedagogia pela Universidade Federal de Rondônia - Campus José Ribeiro Filho/PVH. Participante do Grupo de Pesquisa HISTCULT - Educação, Psicologia Educacional e Processos Formativos e atua na área da Educação Infantil. Belém/PA - Brasil.Lattes: http://lattes.cnpq.br/6861013510201855. ORCID: http://orcid.org/00000002-3705-0656. E-mail: correasantosrs@gmail.com

Edilene Ferreira Gama Mestranda no Programa de Pós-Graduação em Educação da Universidade Federal de Rondônia. Orientadora Educacional vinculada à Secretaria de Estado da Educação, lotada em Extrema. Participante do grupo de pesquisa Centro de Estudos e Pesquisas do Humanismo Ikeda. Lattes: http://lattes.cnpq.br/4944462033801512. ORCID: https://orcid. org/0000-0001-5910-5163. E-mail: prof.edi@gmail.com

Eliane Bastos Mestra em Educação pelo Programa de Pós-Graduação PPGE/UNIR. Professora Voluntária do departamento de Ciências Jurídicas da Universidade Federal de Rondônia. Pesquisadora atuando, principalmente, nas seguintes áreas: Políticas Públicas de Ações Afirmativas; Direito das Minorias, Pluralismo Jurídico e Direitos Humanos; Direito Alternativo; Educação Sociedade e Comunicação; Mídias e Direitos Humanos. Possui graduação em Direito. Graduada em Ciências Sociais - Licenciatura e Bacharelado. Professora com formação em Magistério. Lattes: http://lattes.cnpq. br/8564478336193137. ORCID: https://orcid.org/0000-0002-9555-6102. E-mail: liabastosunir@gmail.com 
Ely Sandra Carvalho de Oliveira Mestre em Educação do Programa Pós-graduação em Educação da Universidade Federal de Rondônia - UNIR. Pedagoga pela Universidade Federal de Rondônia- UNIR, Supervisora Escolar na Secretaria Municipal de Educação - SEMED de Nova Mamoré, analista em Trânsito/Pedagoga do Departamento Estadual de Trânsito/DETRAN-RO. Lattes: http://lattes.cnpq.br/9683200426126777. ORCID: https://orcid. org/0000-0002-1411-6181. E-mail: elycarvalho16@hotmail.com

Eulina Maria Leite Nogueira Licenciatura em Estudos Sociais; Licenciatura em História e Licenciatura em Pedagogia, possui especialização em Educação Especial, Mestrado e Doutorado em Educação. Professora e Pedagoga da rede pública do Estado do Amazonas de 1986-2005, professora adjunta da Universidade Federal do Amazonas desde 2006. Trabalha na formação de professores e desenvolve atividades de pesquisa e extensão em Educação do Campo, Educação Indígena, Políticas Públicas e Currículo. Lattes: http://lattes.cnpq. br/7518673342621764. ORCID: https://orcid.org/0000-0002-7725-6464. E-mail: eulinanog@hotmail.com

Fábio Santos de Andrade Educador Social. Professor Adjunto do Departamento Acadêmico de Ciências da Educação (DACIE) e do Programa de Pós-Graduação em Educação Escolar - Mestrado e Doutorado Profissional (PPGEE) da Universidade Federal de Rondônia (UNIR). Graduado em História e Especialista em Políticas Públicas e Educação pela Universidade Estadual do Sudoeste da Bahia (UESB). Mestre em Ciências Sociais (área de Sociologia) pela Pontifícia Universidade Católica de São Paulo (PUC-SP). Doutor em Educação pela Universidade Federal de Mato Grosso (UFMT). Pós-doutorando em Educação pela Universidade Estadual do Sudoeste da Bahia (UESB). Líder do HUMANIZE: Grupo de Pesquisa sobre História, Educação Social e Vida Cotidiana. Vice Líder do Grupo de Estudos Pedagógicos (GEP). Coordenador do Grupo de estudos sobre crianças e adolescentes em situação de risco (DACIE/UNIR). Pesquisador do Grupo de Pesquisa em Movimentos Sociais e Educação (GPMSE/UFMT). Membro do Conselho Fiscal da Associação 
Brasileira de Pesquisadoras e Pesquisadores pela Justiça Social (ABRAPPS). Membro da Associação Nacional de Pós-Graduação e Pesquisa em Educação (ANPEd). Membro da Associação Brasileira de Pesquisadores/as Negros/as (ABPN). Membro da Rede Brasileira de Educação em Direitos Humanos (ReBEDH). Lattes: http://lattes.cnpq.br/5697273914732427. ORCID: https:// orcid.org/0000-0002-5658-4485.E-mail: fabioandrade@unir.br

Fernanda Amorim Accorsi Doutora e Mestra em Educação (UEM/PR). Especialista em Comunicação e Educação (FCV/PR). Pedagoga (UEM/PR). Jornalista pelo Centro de Ensino Superior do Paraná. Professora Adjunta do Departamento de Educação (DEDI), Campus Prof. Alberto Carvalho, da Universidade Federal de Sergipe (UFS). Coordenadora do grupo de Pesquisas e Estudos em Práticas Educativas, Corpo e Ambiente (PEPECA/DEDI/ UFS). Lattes: http://lattes.cnpq.br/9618868352125200. ORCID: https://orcid.org/0000-0001-6500-094X. E-mail: accorsifer@gmail.com

Gerson da Silva Januário Mestre em Educação (Ufac) Campus Rio Branco/AC. Auditor de Controle Externo no Tribunal de Contas do estado do Acre. Lattes: http://lattes.cnpq.br/6927730180886520. ORCID: https://orcid.org/0000-0002-0354-130X. E-mail: ger5668@gmail.com

Josemir Almeida Barros Pós-Doutor, Doutor e Mestre em Educação, Historiador e Pedagogo. Professor, Pesquisador e Extensionista da Universidade Federal de Rondônia (UNIR), Porto Velho, Rondônia, Brasil. Vinculado ao Departamento de Ciências da Educação (DECED) e Programas de Pós-Graduação em Educação Escolar, Mestrado e Doutorado Profissional (PPGEEProf) e Mestrado Acadêmico (PPGE). Vice-líder do Grupo de Pesquisa Multidisciplinar em Educação e Infância (EDUCA). Vice-Presidente da Rede de Pesquisa, Ensino e Extensão em Educação das Regiões Centro-Oeste e Norte do Brasil e América Latina (RECONAL-Edu). Lattes: http:// lattes.cnpq.br/3625890466420467. ORCID: http://orcid.org/0000-00022687-6575. E-mail: josemir.barros@unir.br 
Juliana Cândido Matias Doutoranda em Educação pelo Programa de Pós-Graduação em Educação Escolar, Mestrado e Doutorado Profissional da Universidade Federal de Rondônia (PPGEE/Prof/UNIR). Mestra em Educação pelo PPGE/UNIR. Pedagoga. Integrante do Grupo de Pesquisa Multidisciplinar em Educação e Infância (EDUCA). Professora da Secretaria Estadual de Educação/SEDUC. Rolim de Moura, Brasil. Lattes: http:// lattes.cnpq.br/2959884192962169. ORCID: https://orcid.org/0000-00028573-6724. E-mail: juhmatias.rm@gmail.com

Luís Alípio Gomes Doutorado em Ciências Ambientais PPGSND/Ufopa. Técnico Administrativo em Educação no cargo de Pedagogo na Pró-reitoria de Ensino da Universidade Federal do Oeste do Pará, Campus Santarém. Professor da Rede Pública Municipal de Ensino do Município de Santarém. Participantes dos seguintes Grupos de Pesquisa: PRAXIS UFOPA; Grupo de Estudos, Pesquisa e Extensão em Educação Ambiental - GEPPEA; Grupo de Estudo e Pesquisa em Indigenismo, Sociedade e Educação na Amazônia - ISSSEAM e da Red Internacional de Filosofia Ecológica Integral. Lattes: http://lattes.cnpq.br/5027565892113181. ORCID: https:// orcid.org/0000-0002-6791-9244.E-mail: luisalipiogomes@hotmail.com

Maria Lília Imbiriba Sousa Colares Doutora e Pós-doutora em Educação pela Universidade Estadual de Campinas (Unicamp). Docente do Programa de Pós-graduação em Educação da Universidade Federal do Oeste do Pará-Ufopa. É vice coordenadora do Fórum de Editores de Periódicos de Educação das Regiões Norte e Nordeste. Bolsista do CNPq. Líder Adjunta do Grupo de Estudos e Pesquisas História, Sociedade e Educação no Brasil/HISTEDR/ Ufopa. Lattes: http://lattes.cnpq.br/9671465461954562. ORCID: http://orcid.org/0000-0002-5915-6742.E-mail: maria.colares@ufopa.edu.br

Maria Sousa Aguiar Mestra em Educação pelo Programa de Pós-graduação em Educação da Universidade Federal do Oeste do Pará (PPGE/Ufopa), Campus Santarém-Pará. Licenciada em Pedagogia pela Universidade Federal do Pará (UFPA). Técnica em Assuntos Educacionais da Ufopa. Integrante do Grupo 
de Estudos e Pesquisas História, Sociedade e Educação no Brasil/HISTEDR/ Ufopa. Lattes: http://lattes.cnpq.br/9705141570593668. ORCID: https://orcid.org/0000-0001-5485-6072. E-mail: msousaaguiar@yahoo.com.br

Mark Clark Assen de Carvalho Doutor em Educação (PUC-SP). Professor Titular do Centro de Educação, Letras e Artes da Universidade Federal do Acre/Ufac, Campus Rio Branco, e Professor Permanente do Programa de Pós-Graduação em Educação da Ufac e do Doutorado em Rede/EDUCANORTE. Lattes: http://lattes.cnpq.br/0736995836464424. ORCID: https://orcid. org/0000-0003-3638-9719. E-mail: markassen@yahoo.com.br

Nilce Vieira Campos Ferreira Professora Adjunta da Universidade Federal de Mato Grosso - UFMT/Cuiabá/MT e do Programa de Pós-Graduação em Educação - PPGE/Cuiabá/MT. Pós-doutorado, Doutorado e Mestrado em Educação. Coordenadora da Rede de Pesquisa, Ensino e Extensão em Educação das Regioes Centro-Oeste e Norte do Brasil e da América Latina - RECONAL-Edu; do Centro Memória Viva do Instituto de Educação da UFMT/Cuiabá - CMVIE; do Grupo de Pesquisa e Estudos em História da Educação, Instituiçôes e Gênero - GPHEG. Conselheira da Sección de Educação da Latin American Studies Association - LASA: Educación y Politicas Educativas en América Latina. Desenvolve pesquisas com o apoio do Conselho Nacional de Desenvolvimento Científico e Tecnológico - CNPq. Lattes: http://lattes.cnpq.br/3948893613479712. ORCID: https://orcid.org/00000002-9165-0011. E-mail: nilcevieiraufmt@gmail.com

Rafael Fonseca de Castro Doutor em Educação. Professor do Departamento de Ciências da Educação - Campus Porto Velho. Docente Permanente do Programa de Pós-Graduação em Educação (PPGE) e do Programa de Pós-Graduação em Educação Escolar (PPGEProf). Líder do Grupo de Pesquisa HISTCULT - Educação, Psicologia Educacional e Processos Formativos. Universidade Federal de Rondônia (UNIR). Porto Velho/RO - Brasil. Lattes: http://lattes.cnpq.br/8727450794536784. ORCID: http://orcid.org/0000-0001-5897-851x. E-mail: castro@unir.br 
Rita Diniz Barboza Acadêmica do curso de Pedagogia do Instituto de Educação, Agricultura e Ambiente - IEAA, da Universidade Federal do Amazonas, UFAM. Lattes: http://lattes.cnpq.br/6723107043109786. ORCID: http:// orcid.org/0000-0002-2338-3505. E-mail: rita.diniz.barboza@gmail.com

Rosangela Aparecida Hilário Pós-Doutora em Educação (FEUSP/SP) Doutora em Educação (FEUSP/SP). Mestra em Educação (UNINOVE). Possui licenciatura em Letras (Anhembi-Morumbi). Graduação em Comunicação Social/Jornalismo (UMC). Professora do Departamento de Ciências da Educação de Porto Velho e do Programa de Pós-Graduação em Educação (PPGE), Campus José Ribeiro Filho da Universidade Federal de Rondônia (UNIR). Líder do Grupo de Pesquisa Ativista Audre Lorde. Atua principalmente nas áreas de interseccionalidade, feminino e feminismo negro, alfabetização e letramento. Parecerista ad hoc das Revistas Educação e Pesquisa/FEUSP, Praxis Pedagógica/MEDUC/UNIR, Revista de Estudos Interdisciplinares de Arte e Educação da UERJ e da Revista Olhares da UNIFESP. Membro do Conselho Editorial da Revista Práxis. Lattes: http://lattes.cnpq.br/8819241283467661. ORCID: https://orcid.org/0000-0003-0308-8557.E-mail: rosangela.hilario@unir.br

Rosângela de Fátima Cavalcante França Doutora em Educação pela Universidade Estadual Paulista (UNESP). Professora do Departamento de Educação (DECED) e no Programa de Pós-Graduação Strictu Sensu, Mestrado Acadêmico em Educação (PPGE) da Universidade Federal de Rondônia (UNIR), líder do grupo de pesquisa PRAXIS UNIR, Porto Velho - RO, Brasil. Lattes: http://lattes.cnpq.br/1329287561873949. ORCID: https://orcid.org/00000003-2301-7000.E-mail: rosangela.franca@unir.br

Samilo Takara Pós-Doutor em Comunicação (UEL/PR). Doutor em Educação (UEM/PR). Docente no Departamento Acadêmico de Educação e na Especialização em Gênero e Diversidade na Escola, Campus Rolim de Moura e, no Programa de Pós-Graduação em Educação (PPGE), Campus José Ribeiro Filho da Universidade Federal de Rondônia (UNIR). Líder do Grupo de Estudos e Pesquisas em Estudos Culturais e Educação Contemporânea (GEPECEC/UNIR). Lattes: http://lattes.cnpq.br/9453815210695929. ORCID: https://orcid.org/0000-0002-8775-6278. E-mail: samilo@unir.br 
Tânia Suely Azevedo Brasileiro Pós-doutorado em Psicologia (USP) e Doutorado em Educação (URV-ES/USP). Professora Titular da Universidade Federal do Oeste do Pará (Ufopa), Santarém/PA. Líder do Grupo de pesquisa PRAXIS UFOPA, membro do Laboratório Interinstitucional de Estudos e Pesquisas em Psicologia Escolar - LIEPPE/USP da Rede Inter-regional Norte, Nordeste e Centro Oeste sobre Docência da Educação Básica e Superior - RIDES e da Rede Internacional de Filosofia Ecológica Integral. Lattes: http://lattes.cnpq.br/7125374751055075. ORCID: http://orcid.org/00000002-8423-4466. E-mail: brasileirotania@gmail.com

Vinicius de Souza Santos Graduado de Pedagogia pela Universidade Federal de Rondônia (UNIR), Pesquisador e Integrante do Grupo de Pesquisa Ativista Audre Lorde, em Porto Velho - Rondônia. Tem experiências como Bolsista CNPq pelo Programa de Iniciação Científica - PIBIC/UNIR - com ênfase em temáticas que envolvem Educação, Gênero e Sexualidades, Feminismo Negro e Inclusão. Tem experiências nas áreas de que envolvem a Língua Brasileira de Sinais: atuando com Monitor Acadêmico especial de graduandos surdos da UNIR e Bolsista Tradutor e Intérprete de Língua Brasileira de Sinais, onde atualmente trabalha. Lattes: http://lattes.cnpq.br/9743579175543977. ORCID: http://orcid.org/0000-0002-0645-8595. E-mail: igualatodos@live.com

Wendell Fiori de Faria Pós-Doutor em Educação pela Universidade de São Paulo (FEUSP). Professor do Departamento de Educação (DECED) e no Programa de Pós-Graduação Strictu Sensu, Mestrado Acadêmico em Educação (PPGE) da Universidade Federal de Rondônia (UNIR), Porto Velho - RO, Brasil. Lattes: http://lattes.cnpq.br/9618312160926172. ORCID: https://orcid.org/0000-0003-4195-1876. E-mail: professorfiori@gmail.com

Wesley Cristian Mercês Teixeira Mestre em Educação pela Universidade Federal de Rondônia. Licenciado em Filosofia pela Faculdade Católica de Rondônia. Professor da Faculdade de Rondônia (FARO). Membro do Grupo de Pesquisa Práxis, da Universidade Federal de Rondônia. Lattes: http://lattes. cnpq.br/4000659561976989. ORCID: https://orcid.org/0000-0003-2036121X. E-mail: teixeirawes@gmail.com 


\section{级UNIR}

A Fundação Universidade Federal de Rondônia (UNIR) é uma instituição pública de ensino superior criada em 1982. Ao longo de aproximados 40 anos, as ações de ensino, pesquisa e extensão formaram profissionais qualificados para atuação em todas as esferas da sociedade e do mercado de trabalho. A partir do ano 2000, com o início da oferta de cursos de Pós-Graduação, essa ação foi sendo ampliada, sendo ofertados, atualmente, 24 mestrados e 04 doutorados, abrangendo diversas áreas do conhecimento e priorizando pesquisas atinentes às questões ambientais, sociais, educacionais, culturais, econômicas e geográficas da Amazônia e especialmente de Rondônia. Como política de apoio e fortalecimento à Pós-Graduação e à pesquisa na Universidade, a Pró-Reitoria de Pós-Graduação e Pesquisa (PROPESQ) instituiu a publicação de livros elaborados pelos programas de Pós-Graduação, como atividade de divulgação e compartilhamento dos resultados das pesquisas produzidas por pesquisadores desta Instituição, tendo a Editora da Universidade Federa de Rondônia (EDUFRO), como unidade sistematizadora de todas as produções. Dessa forma, esta coleção, composta por 13 livros elaborados cada um por um PPG da UNIR, apresenta temas e abordagens disciplinares e transdisciplinares, divulga os resultados das pesquisas elaboradas nessa Instituição e aproxima a UNIR das Instituições Estaduais, Municipais e de toda a Sociedade.

Maria Madalena de Aguiar Cavalcante - Diretora de Pós-Graduação Artur de Souza Moret - Pró-Reitor de Pós-Graduação e Pesquisa

O desafio da Fundação Universidade Federal de Rondônia no ensino de graduação e de Pós-Graduação nunca foi tão grande, principalmente a partir dos recursos cada vez menores. Nesta pandemia por covid-19, o desafio foi não parar e a Pós-Graduação da UNIR não parou: defesas de dissertações e teses tornaram-se on-line e as produções acadêmicas-científicas não cessaram. Estes 13 livros da Coleção Pós-Gradução são a demonstração de que o esforço para o crescimento e a consolidação se mantém firme e constante. O futuro da Pós-Graduação na UNIR é o resultado das ações articuladas entre todos os atores, com maior abertura para a sociedade e para os setores públicos e com um grande objetivo que nos motiva, o de contribuir na formação em excelência de professores e pesquisadores nos países limítrofes. Os resultados nos colocam em papel de destaque na Amazônia e é isso o que desejamos: ser uma Instituição pública e gratuita, com forte apoio da sociedade para a oferta de cursos e formações que promovam o Desenvolvimento Regional e Sustentável do Estado de Rondônia

Marcele Regina Nogueira Pereira - Reitora
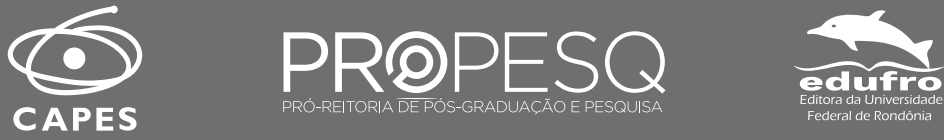